\title{
Three (middle to) late Miocene plant macroremain assemblages (Pitsidia, Kassanoi and Metochia) from the Messara-Gavdos region, southern Crete
}

\author{
GIANNIS ZIDIANAKIS ${ }^{1,2^{*}}$, GEORGE ILIOPOULOS ${ }^{1}$, AVRAAM ZELILIDIS ${ }^{1}$ \\ and JOHANNA KOVAR-EDER ${ }^{3}$ \\ ${ }^{1}$ Geology Department, University of Patras, University Campus, 26504 Rio, Greece; e-mail: zidiag@upatras.gr \\ ${ }^{2}$ Agriculture Department, Hellenic Mediterranean University, Estavromenos, 71410 Heraklion, Greece \\ ${ }^{3}$ State Museum of Natural History Stuttgart, Rosenstein 1, 70191 Stuttgart, Germany
}

Received 12 July 2020; accepted for publication 30 November 2020

\begin{abstract}
Based on macroremains, we describe three fossil plant assemblages from the Miocene of the Messara Basin (southern Crete) and the adjacent Gavdos Island. The palaeoflora of Kassanoi, which is the oldest (Messara Basin, Viannos Fm, Serravallian/early Tortonian), is documented mainly by leaf imprints, including a fern, a conifer (Tetraclinis cf. salicornioides) and 23 angiosperms. The assemblage is dominated by Daphnogene polymorpha, Podocarpium podocarpum and Myrica lignitum. The plant record from Pitsidia (Messara Basin, Ambelouzos Fm, early Tortonian) comprises thousands of specimens. The plant fossils are preserved as imprints often covered by an inorganic encrustation (replica). One alga, 2 ferns, at least 5 conifers and more than 45 woody angiosperms were identified. Dominant taxa are Myrica and Pinus pitsidiensis, documented by numerous vegetative and reproductive organs (Zidianakis et al., 2015, 2016). Leaves of oaks (Q. pseudocastanea, Q. kubinyii) and Daphogene polymorpha as well as twigs of Taxodium dubium are also fairly common. From the palaeoflora of Metochia, which is the youngest (Gavdos Island, Metochia Fm, middle Tortonian), (Mantzouka et al., 2015), we report further taxa, including Quercus mediterranea, Ziziphus paradisiaca and a palm (Sabalites sp.).

The vegetation is assessed both empirically (phytosociologically) and by Integrated Plant Record (IPR) Vegetation Analysis. The reconstructed vegetation models are presented in detail and discussed in the context of the geological and palaeontological settings of the area. The climate is assessed based on the Coexistence Approach (CA) and the Climate Leaf Analysis Multivariate Program (CLAMP). The palaeoclimatic datasets reveal a warm temperate to subtropical climate, probably with a weak seasonal drought.
\end{abstract}

KEYWORDS: plant macroremains, Miocene, Crete, plant systematics, palaeovegetation, palaeoclimate

\section{INTRODUCTION}

In the early Miocene, a continuous landmass, Aegeis, emerged as part of the northern coast of the declining Tethys Ocean covering the current Aegean and Cretan Sea area (Dermitzakis and Papanikolaou, 1981). During the transition period from the middle to the late Miocene, a fan-like southward expansion took place, leading to the break-up of the southern

\footnotetext{
Corresponding author
}

part of Aegeis and ultimately to the formation of numerous separate islands (Dermitzakis and Papanikolaou, 1981; Meulenkamp and Sissingh, 2003). In such a dynamic tectonic system, the plant fossil record opens time windows into the past, offering insights into the major environment changes.

Contrary to other parts of Greece, the exploration history of the Cenozoic floras in Crete is rather recent. Velitzelos and Gregor (1990) 


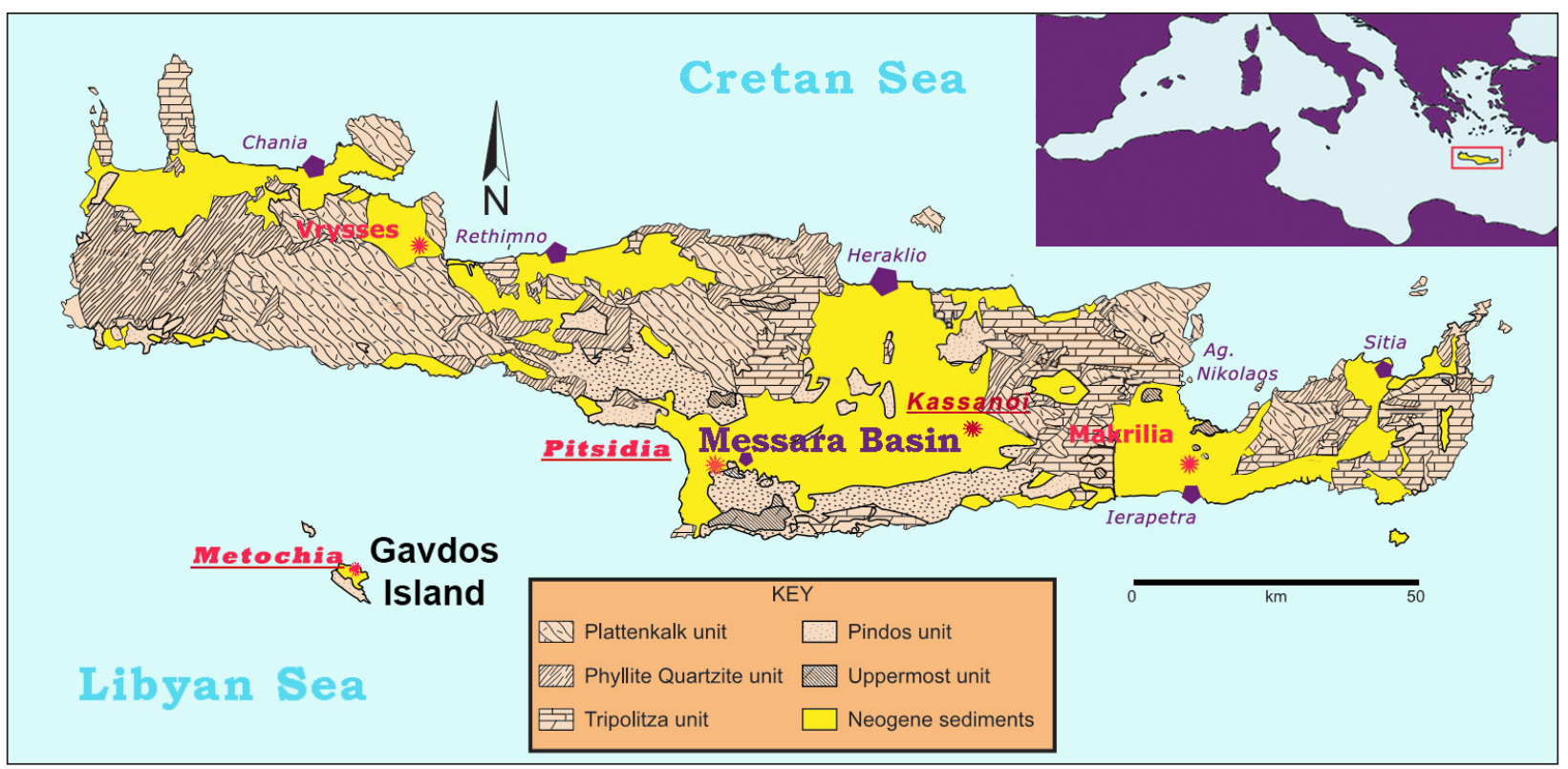

Fig. 1. Geological map of Crete and Gavdos islands, showing the localities bearing plant macroremains (modified from I.G.M.E., 1993); the localities studied herein are underlined

reported pine cones from the area of Achlia village (Appx. 1) in the eastern part of Crete, without providing a description or illustration. Later, Mohr et al. (1991) discovered a late Miocene plant assemblage close to Makrilia village in eastern Crete (Fig. 1). Approximately 130 taxa were identified based on foliage and diaspores as well as palynomorph remains (Sachse and Mohr, 1996; Sachse, 1997, 2004; Sachse et al., 1999). In the early $21^{\text {st }}$ century, leaf impressions in limestone blocks were encountered in Vrysses, northwestern Crete (Zidianakis et al., 2007) (Fig. 1). This late Miocene assemblage comprises mostly poorly preserved foliage and rarely seed or fruit remains. Kröger (2004) studied the sedimentary environments of the western Messara Basin, noting the occurrence of plant macrofossils in fine-grained layers near Pitsidia village. He reported an outcrop 1-2 km SW of this village that yielded a florula. Because of extensive earthworks, the plant-bearing layers became easily accessible, and in 2008 a new outcrop rich in plant fossils was discovered (Zidianakis et al., 2010).

Recently, Velitzelos D. et al. (2014) published a review of the Cenozoic floras of Greece, illustrating a few new findings from Makrilia and providing amended species lists for the Cretan palaeofloras. From Pitsidia, Zidianakis et al. (2015, 2016) described mass occurrences of Myrica and Pinus pitsidiensis Zidianakis, Iliopoulos, Zelilidis, Kovar-Eder, including vegetative and reproductive organs. Plant-arthropod interactions were studied by Zidianakis et al. (2020), whereby the leaves of Myrica lignitum provide evidence of arthropod physiology, feeding and reproduction, with several types of damage.

Studies on plant sporomorphs from Neogene sediments of Crete are quite diverse, including Tortonian pollen spectra from Makrilia, Kastellios Hill, Plakias, Georgioupolis, Viglotopi, Triopetra and Almiri Panagia localities, the Messinian Perama/Dafnedes and Agia Varvara, as well as from the Pliocene of Agios Vlassios (Benda et al., 1974; van der Weerd, 1983; Sen et al., 1986; Drivaliari, 1993) (Appx. 1).

Unlike for Crete, the occurrence of terrestrial plant macroremains from the adjacent Gavdos Island was noticed by geologists already in the $19^{\text {th }}$ century (Simonelli, 1894). More recently, several studies referred to the occurrence of plant material lacking descriptions from turbiditic sequences of the Metochia deposits (Postma et al., 1993; Gaudant et al., 2005; Tsaparas, 2005; Fig. 1). Mantzouka et al. (2015) described such plant material collected by Tsaparas (2005).

In this study we present a very rich plant macro-assemblage from Pitsidia and that of Kassanoi (Fig. 1), recently discovered, both situated in the southern part of central Crete. Also, several yet-unrecorded taxa are reported from the published palaeoflora of Metochia, Gavdos Island (Mantzouka et al., 2015). 


\section{GEOGRAPHICAL}

\section{AND GEOLOGICAL SETTINGS}

\section{CRETE ISLAND}

Crete constitutes a prominent horst structure of the southern Aegean Forearc in the still-active Hellenic subduction zone (Fig. 2). Its complex structure has been strongly affected by Alpine orogenic processes in the Eastern Mediterranean, due to the convergence of the Eurasian and African plates and the subduction of the Tethyan oceanic crust (Bonneau, 1984; Lister et al., 1984; Mountrakis et al., 2006; Ring et al., 2010; Maravelis et al., 2015). The geological structure of the island is a complex mosaic of pre-Alpine and Alpine rock comprising the pre-Neogene basement and post-Alpine deposits that fill the Neogene-Quaternary sedimentary basins. The basement is built of a pile of nappes that consist of various rocks from different palaeogeographic zones. Based on tectonostratigraphic position and tectonometamorphic history it is subdivided into two main sequences: the lower one consisting of metamorphic rocks, and the upper one of nonmetamorphic rocks (e.g. Creutzburg and Seidel, 1975; Seidel et al., 1982; Bonneau, 1984; Papanikolaou and Vassilakis, 2010). The Neogene sedimentary sequence of Crete comprises a variety of lithologies reflecting deposition in freshwater, brackish and marine environments, and is subdivided into six major lithostratigraphic groups (Meulenkamp et al., 1979) (Fig. 3).

\section{THE MESSARA BASIN}

Located in the southern part of central Crete, the Messara Basin is developed over the hanging wall of the Cretan Detachment (the tectonic contact of the two main nappe sequences of the Cretan basement), forming a supradetachment basin with deformed basement and several extensional klippen (van Hinsbergen, Meulenkamp; 2006) (Fig. 4). This basin was formed in the Neogene as part of

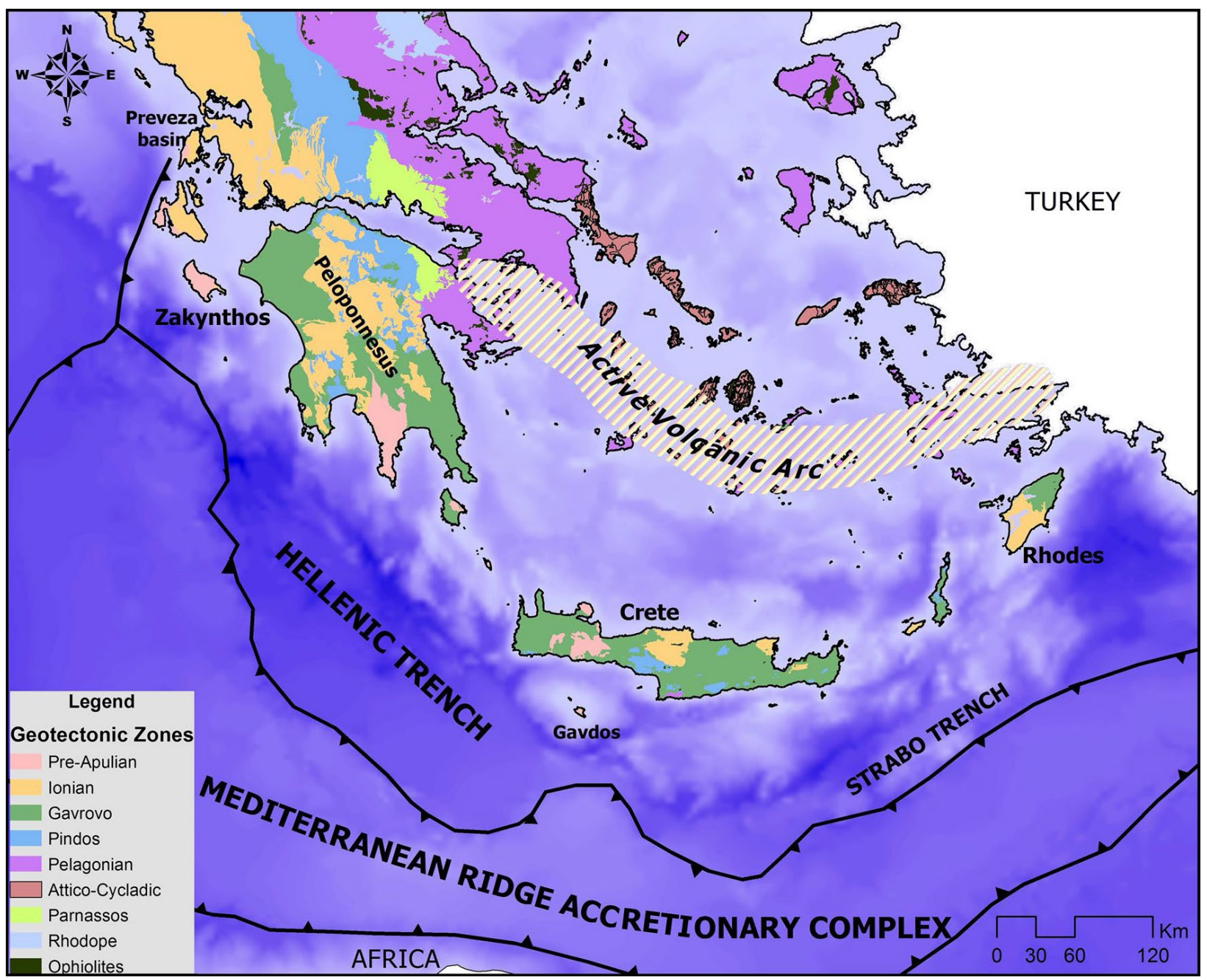

Fig. 2. Geotectonic map of SE Aegean and Crete region (Zelilidis et al., 2016, after Maravelis et al., 2015) 


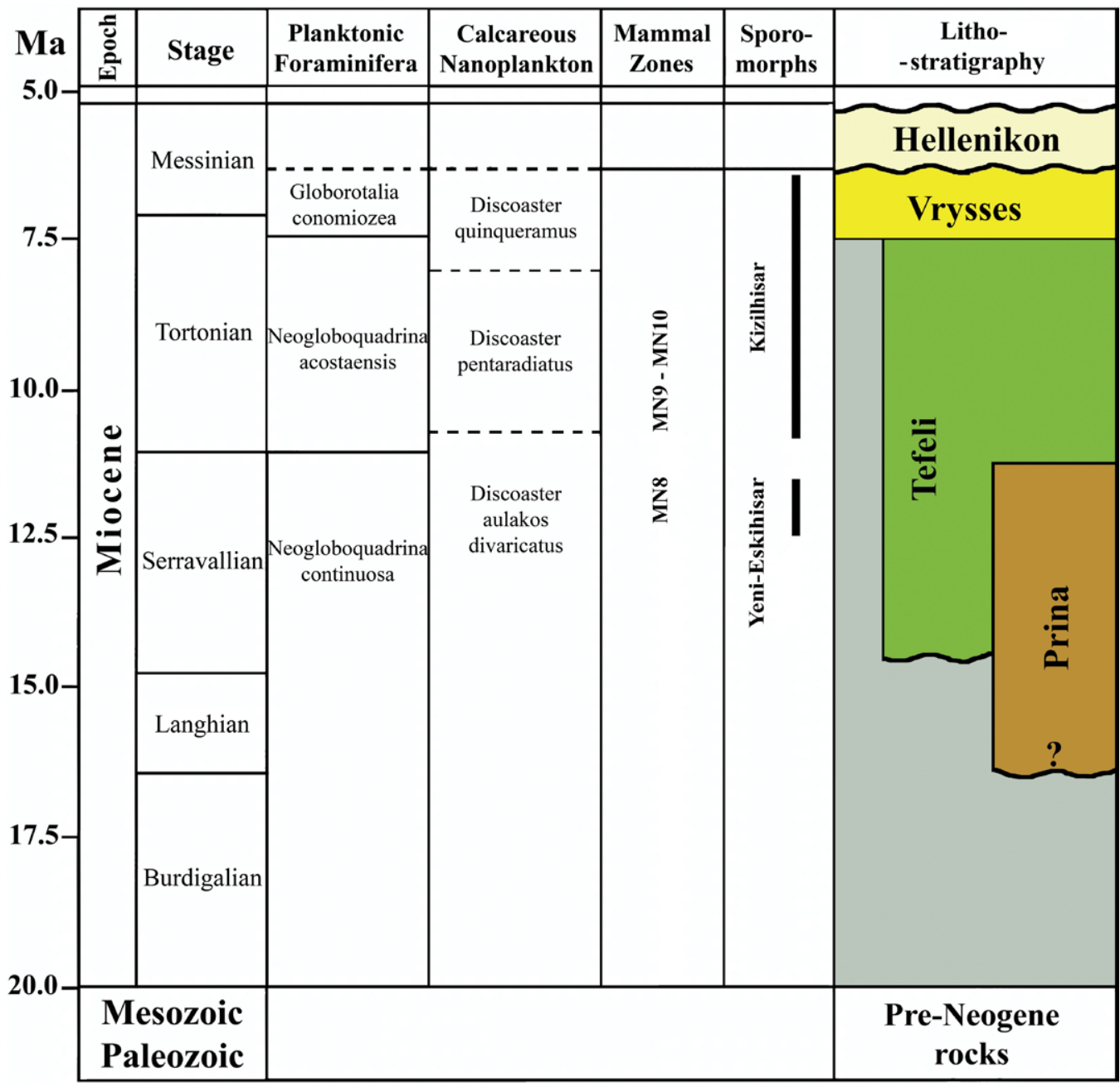

Unconformity

Fig. 3. Litho-chronostratigraphy of the Miocene sediments in Crete (Fassoulas, 2001, after Benda et al., 1974 and Meulenkamp et al., 1979)
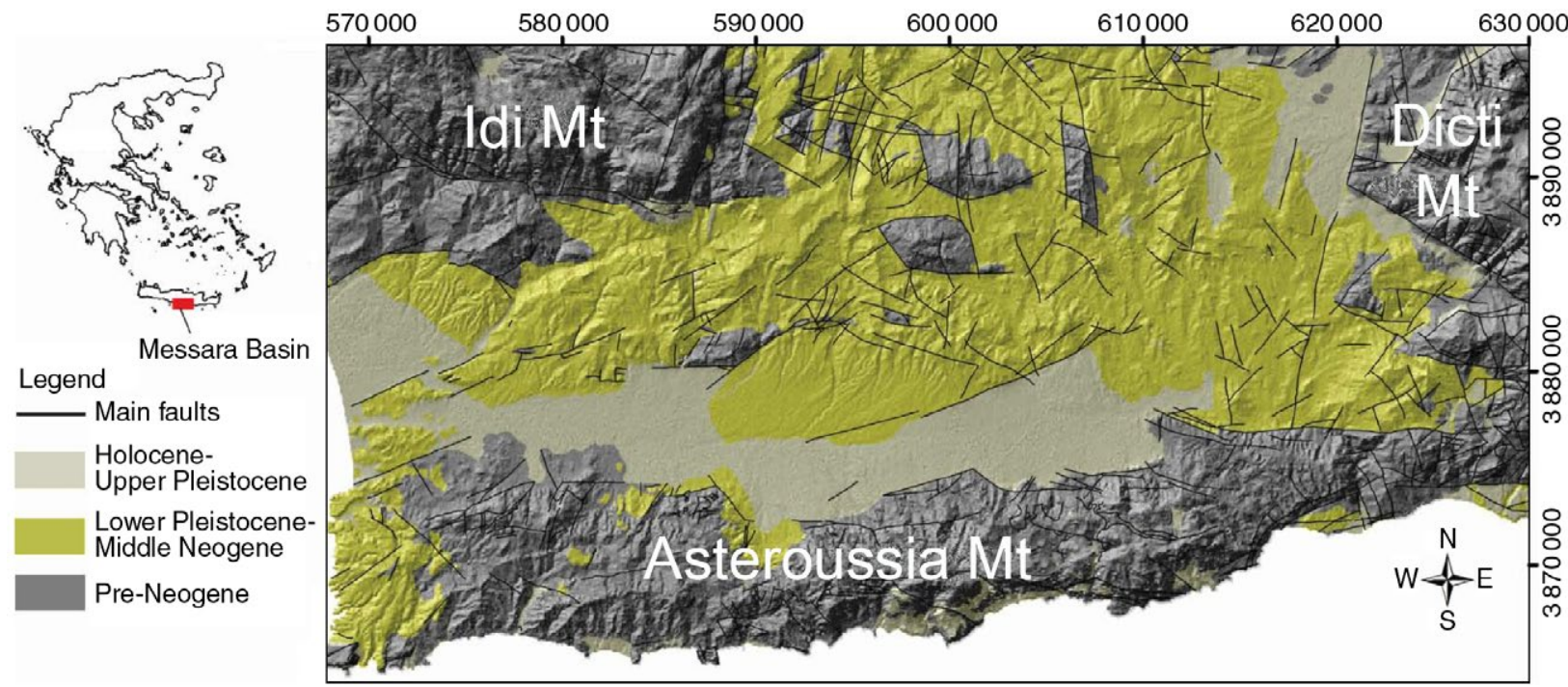

Fig. 4. Neogene deposits and main faults in the Messara Basin (Vafidis et al., 2012, after I.G.M.E., 1993) 
a larger one extending northwards to the area of the present-day Heraklion Basin. During the early Pliocene, tectonic processes separated these two basins by the development of the east-west central Heraklion ridge (Fassoulas, 2001). The sedimentation started during the middle Miocene, resulting in the deposition of sequences lying unconformably upon the basement, characterised by abrupt lateral and vertical changes in lithology (Meulenkamp et al., 1979; Zachariasse et al., 2011; Vafidis et al., 2012). These sequences have undergone multidirectional extensional as well as compressional tectonic events (ten Veen and Postma 1999; van Hinsbergen and Meulenkamp, 2006; Chatzaras et al., 2006).

No formal lithostratigraphic scheme has been established yet for the Neogene deposits of the Messara Basin. According to the preliminary subdivision proposed by Meulenkamp et al. (1979), the Miocene depositional succession of the Basin could be subdivided into four formations characterised by a unique combination of lithology, depositional environment and stratigraphic position:

The Viannos Formation (Serravallian, Tefeli group) constitutes the oldest Neogene unit in the Messara Basin and is dominated by alternations of clay, silt and cemented sandstone of fluvio-lacustrine origin. This formation covers a wide range of depositional environments such as channel-belt, overbank and lacustrine settings. Platy weathered limestones are common, while lignitic clays are infrequent. According to Meulenkamp et al. (1979), the Viannos Fm is considered to be of Serravallian age because the overlying shallow-marine deposits of the Skinias Fm are dated to the early Tortonian (Zachariasse, 1975).

The Skinias Formation (upper Serravallian-lower Tortonian, Tefeli group) consists of marine clays with interbedded sandstones and occasionally gravels conformably overlying the Viannos Fm.

The Ambelouzos Formation (lower-middle/ upper Tortonian, Tefeli group) reaches $350 \mathrm{~m}$ in thickness and disconformably overlies the Skinias Fm. It comprises a variety of lithologies representing fluvial-lacustrine, lagoonal and inner neritic environments. The poorly sorted conglomerates and their associated silty clays, lignites and travertines are interpreted as floodplain deposits dissected by braided channels. The massive oyster beds, silts and clays indicate repeated marine transgressions leading from lagoonal to inner neritic conditions.

The Varvara Formation (middle/upper Tortonian-lower Messinian, Vrysses group) consists of homogeneous to laminated mixed siliciclastic/calcareous marine sequences overlying either conformably the Ambelouzos Fm or with an angular unconformity the Viannos/Skinias Fms or the pre-Neogene basement.

Zachariasse et al. (2011) proposed an upgraded lithostratigtraphic system for the Tortonian-lower Messinian deposits of central Crete. Accordingly, the Miocene sediments of the Messara Basin are classified into a sequence of five formations (subdividing the Varvara Fm into the Moulia and Agios Miron Fms), and ages slightly younger than those proposed by Meulenkamp et al. (1979) were suggested.

\section{GAVDOS ISLAND}

Gavdos Island, situated $37 \mathrm{~km}$ south of Crete, forms the southernmost extension of the South Aegean Island Arc. It covers $\sim 33 \mathrm{~km}^{2}$. The pre-Neogene basement of the island consists of a series of NW-SE-striking thrust units, similar to that of Crete mostly represented by the Pindos unit (carbonates and flysch) as well as ophiolites (Kopp, 1977; Anastasakis et al., 1995) (Fig. 5). Neogene sediments up to $150 \mathrm{~m}$ thick cover two thirds of the island and unconformably overlie the pre-Neogene basement (Vicente, 1970; I.G.M.E., 1993; Anastasakis et al., 1995). These sediments are subdivided into two formations, the Potamos Fm and Metochia Fm (Anastasakis et al., 1995). The mainly marine Potamos Fm (lower/middle Serravallian-lowermost Tortonian) overlies the pre-Neogene basement with an angular unconformity and is considered as a possible timeequivalent to the fluvio-lacustrine sediments of the Viannos Fm and to the marine Skinias Fm in central Crete (Postma et al., 1993; Meulenkamp et al., 1994; van Hinsbergen and Meulenkamp, 2006; Zachariasse et al., 2011). The Metochia Fm (middle-upper Tortonian), up to $50 \mathrm{~m}$ thick, unconformably overlies the preNeogene basement, representing mostly marine environments. Starting from the base, it consists of conglomerates, paleosoils and sandstones, followed by an extended cyclothematic alternation of grey marls with brown-grey "sapropels", finally followed by layers of diatomites, marls and limestones. 


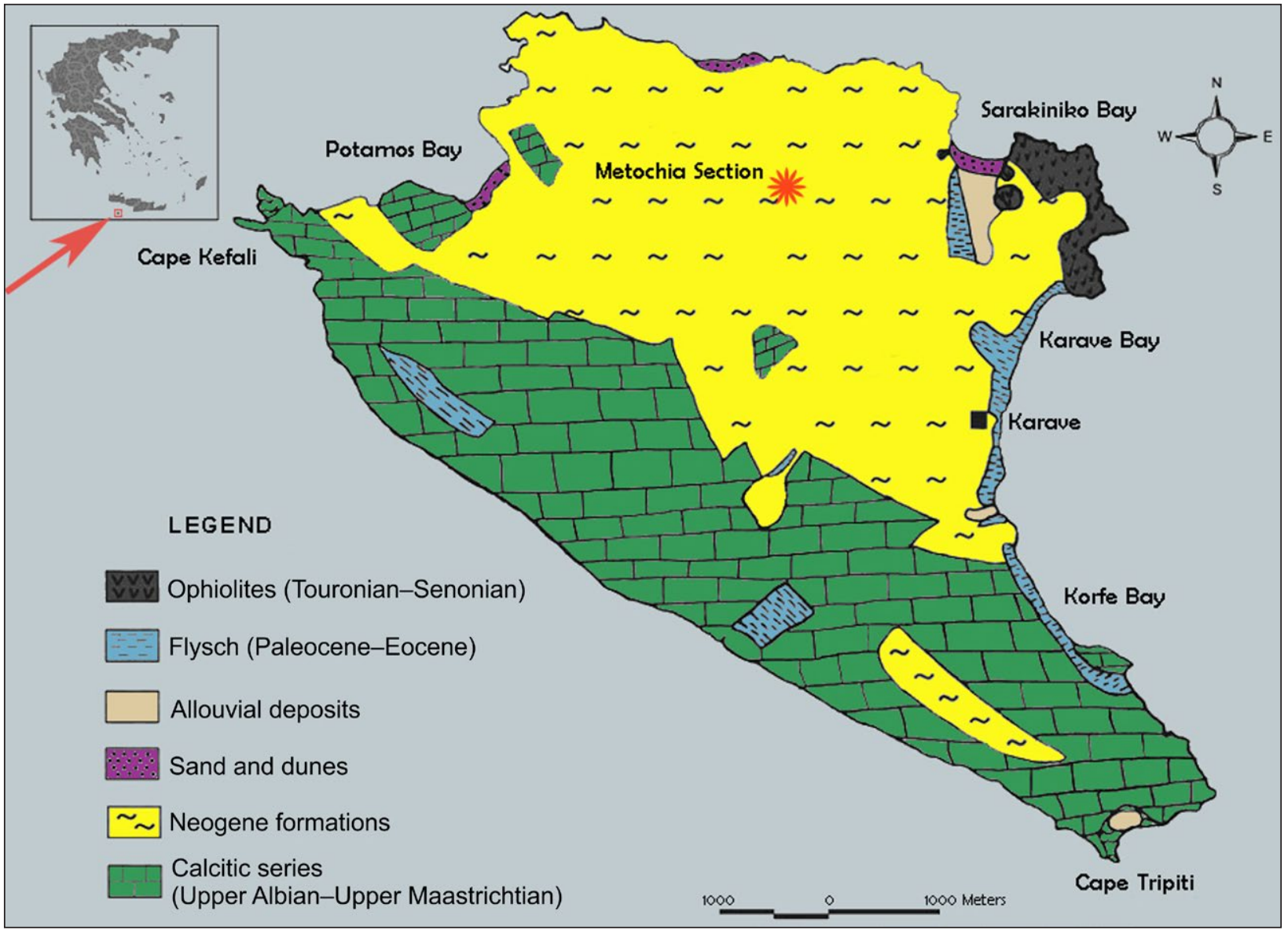

Fig. 5. Simplified geological map of Gavdos Island (Tsaparas, 2005, after I.G.M.E., 1993); the position of the Metochia section is asterisked

\section{THE STUDIED OUTCROPS}

The plant-bearing outcrop of Pitsidia is situated in the southwestern part of the Messara Basin $\sim 1 \mathrm{~km}$ southwest of Pitsidia village (Fig. 1; Pl. 1, fig. 1). The deposits constitute a thick succession of terrigenous clastics, estuarine and shallow-marine sediments of the Ambelouzos Fm, which can be divided into three main lithostratigraphic units (Fig. 6). The main fossiliferous layer (abbreviated here MFL) is 3.5-4.0 m thick, beige to slightly blue-green, fine-grained and poorly lithified. Thin layers are superimposed for the next $1 \mathrm{~m}$, some of them bearing plant remains as well (fossiliferous layers 1 to 3 , abbreviated FL1-3) (Fig. 7). Apart from plant macrofossils, the fossiliferous layers further include isolated fish bones (mainly opercula, praeopercula and spinal bones), fish pharyngeal teeth (Cyprinidae) and sporadic gastropod shells (Planorbidae), ostracod valves (Candonidae) and insect imprints (mostly Coleoptera) (Fig. 8a). Based on Sr-isotope stratigraphy, the plant-bearing layers are dated somewhat older than $10.5 \mathrm{Ma}$, in the early Tortonian (Kröger, 2004).

The outcrop of Kassanoi is situated in the northeastern part of the Messara Basin, on a roadcut leading to Viannos Province, $1 \mathrm{~km}$ southwest of Kassanoi village (Fig. 1; Pl. 1, fig. 2). The section comprises a siliclastic succession of sandstone and silt-clay alternations more than $8 \mathrm{~m}$ thick, brownish to gray, occasionally with freshwater mollusc shells (Fig. 9). In the upper part of the sequence, a coal seam a few $\mathrm{cm}$ thick is developed. Plant remains, mainly leaf impressions, occur in the finegrained intercalations below this coal seam, often co-occurring with plant debris. A horizon with roots preserved in situ is present $\sim 15 \mathrm{~cm}$ below the coal seam (Pl. 2, fig. 5). The presence of in situ root remains and freshwater mollusc shells suggest a fluvio-lacustrine depositional environment for the outcrop. According to the 1:25,000 and 1:50,000 geological maps of IGME (1994; 2002), the outcrop is part of the Viannos Fm, considered of Serravallian age sensu Meulenkamp et al. (1979) or early Tortonian sensu Zachariasse et al. (2011). 

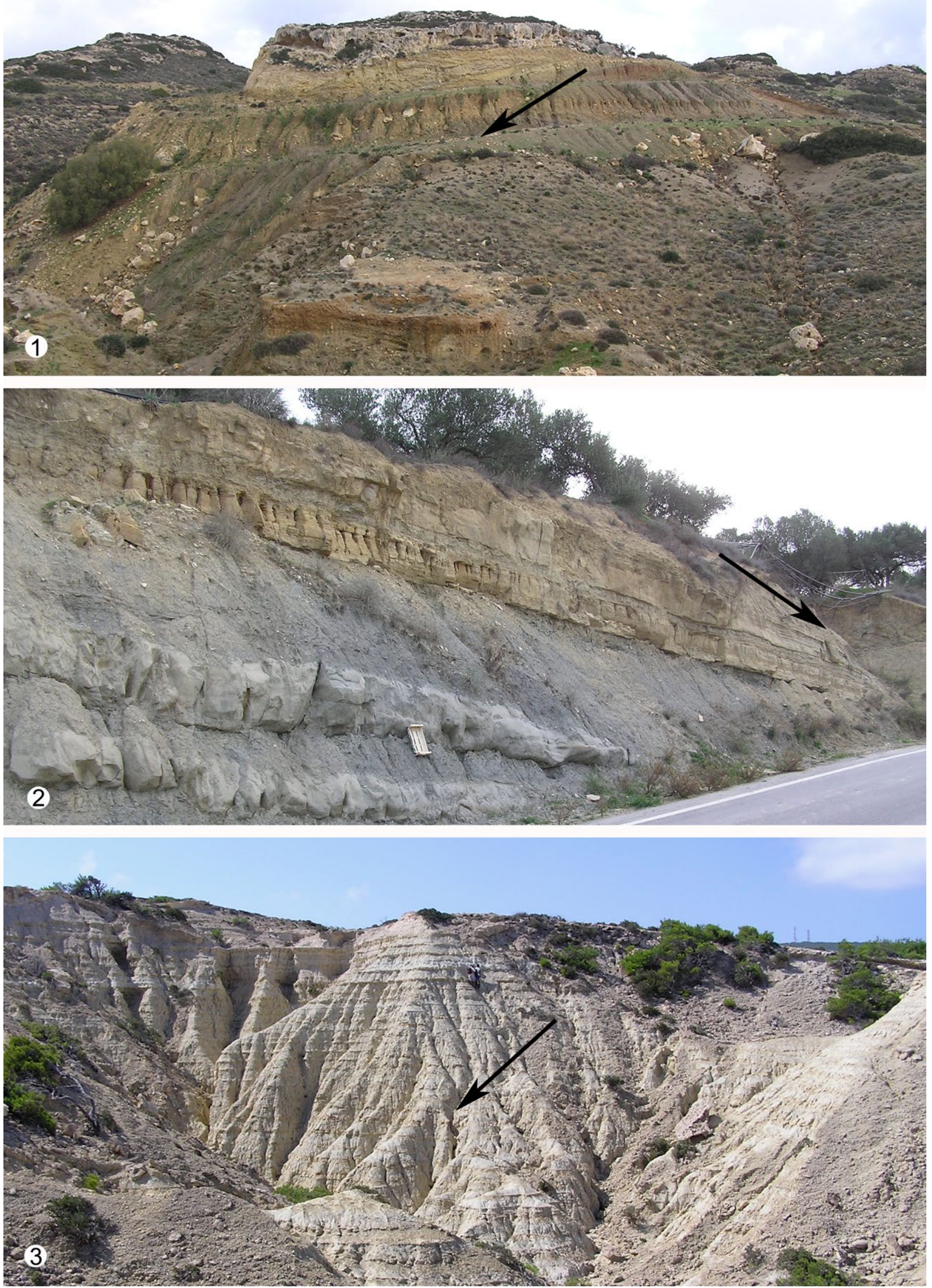

Plate 1. 1-3. General view of the studied areas (arrows indicate plant-bearing outcrops); 1. Pitsidia, western Messara Basin, Crete Island; 2. Kassanoi, eastern Messara Basin, Crete Island; 3. Metochia, Gavdos Island 


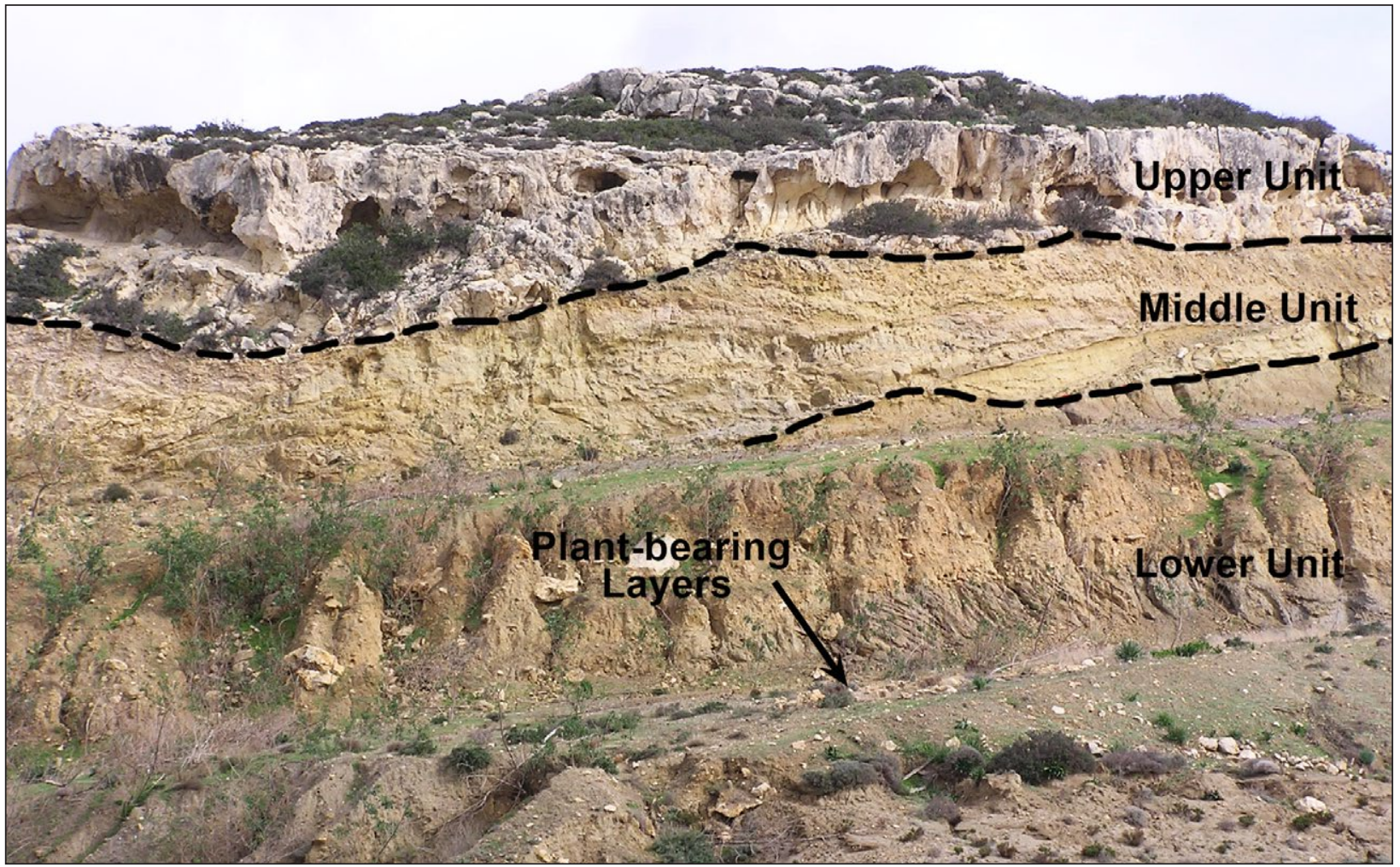

Fig. 6. Pitsidia outcrop; the three litho-stratigraphic units are separated by dashed lines

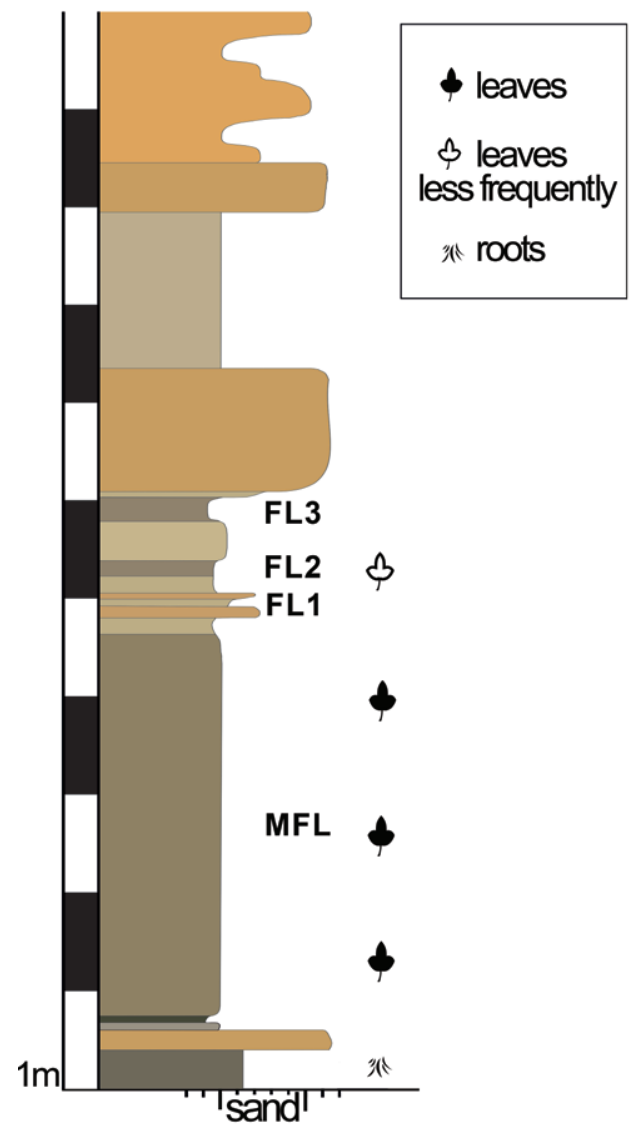

Fig. 7. Litho-stratigraphic sequence of the plant-bearing deposits of Pitsidia
The Metochia outcrop is situated in the northern part of Gavdos Island, $1.5 \mathrm{~km}$ west of Sarakiniko Bay; it is the type section of the Metochia Fm (Figs 5, 10; Pl. 1, fig. 3). The poorly to non-bioturbated laminites (sapropels) of this outcrop are rich in plant macrofossils, mostly leaf imprints. The sediments represent a marine depositional environment which probably was supplied by river flooding. Based on magneto-, bio- and cyclostratigraphic data, the entire Metochia section spans a time interval from 9.7 to 6.6 Ma (Hilgen et al., 1995; Krijgsman et al., 1995). The excavated plantbearing layers match with the Nrs M16-M26 sedimentary cycles corresponding to the middle Tortonian, approximately 9.0-9.4 Ma. The plant material described by Mantzouka et al. (2015) is considered to be of almost the same age because it came from the Nrs M16-M22 "sapropel" layers.

\section{MATERIALS AND METHODS}

From Pitsidia, 6500 slabs with more than 9000 macrofossils were studied, collected from the main fossiliferous layer (MFL) and three superimposed thinner layers (FL1-3) (Fig. 7). Additionally, the material presented preliminarily by Zidianakis et al. (2010) is included herein and commented where necessary 

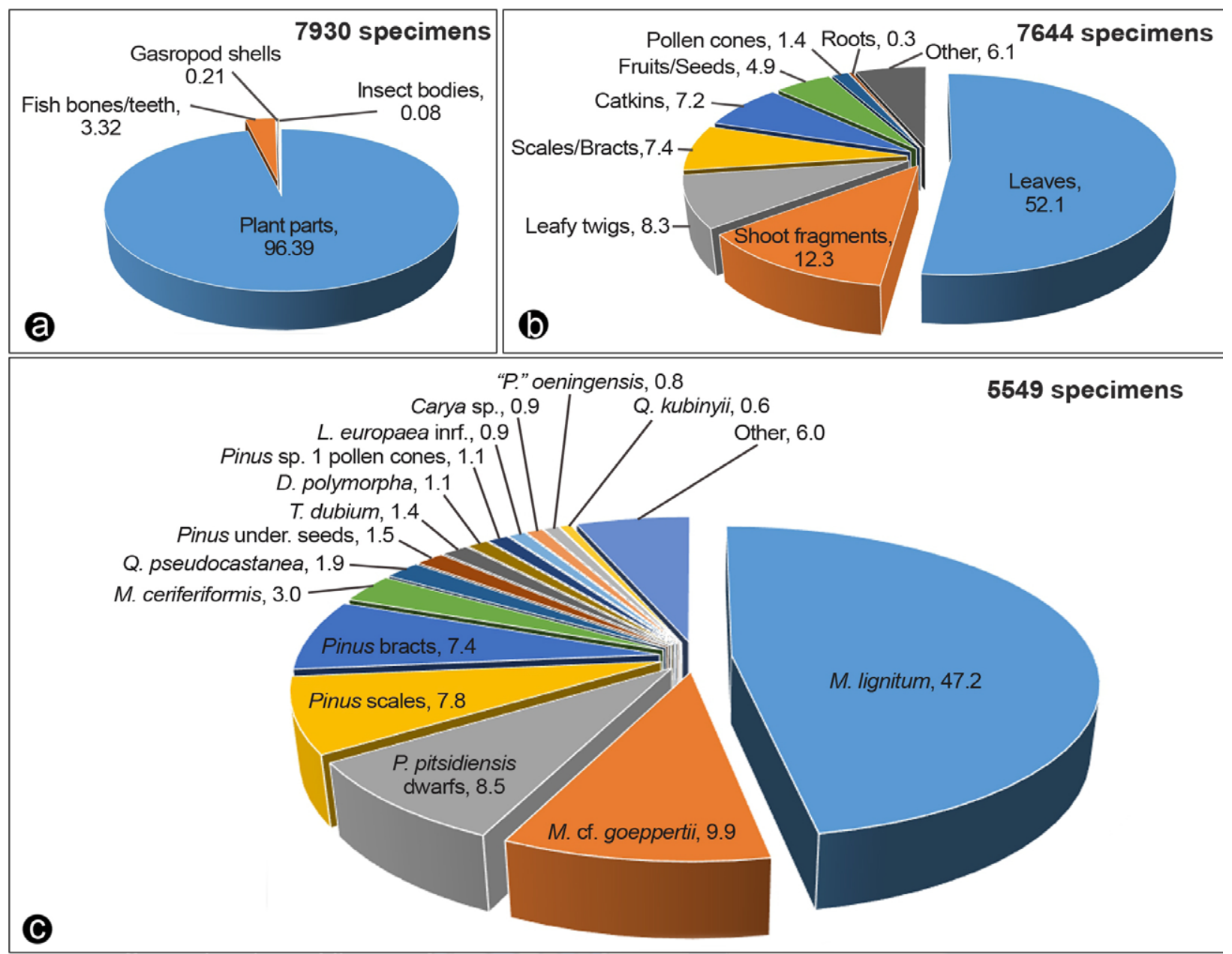

Fig. 8. Palaeoflora of Pitsidia. Frequencies (\%) of different fossils collected from the main fossiliferous layer (MFL) during systematic excavation; a. fossil types (dicot leaf fragments $<1 / 6$ of the original leaf size were ignored, and fish bones were collected only occasionally); b. plant organs/parts; c. plant taxa (frequency $>0.5 \%$ )

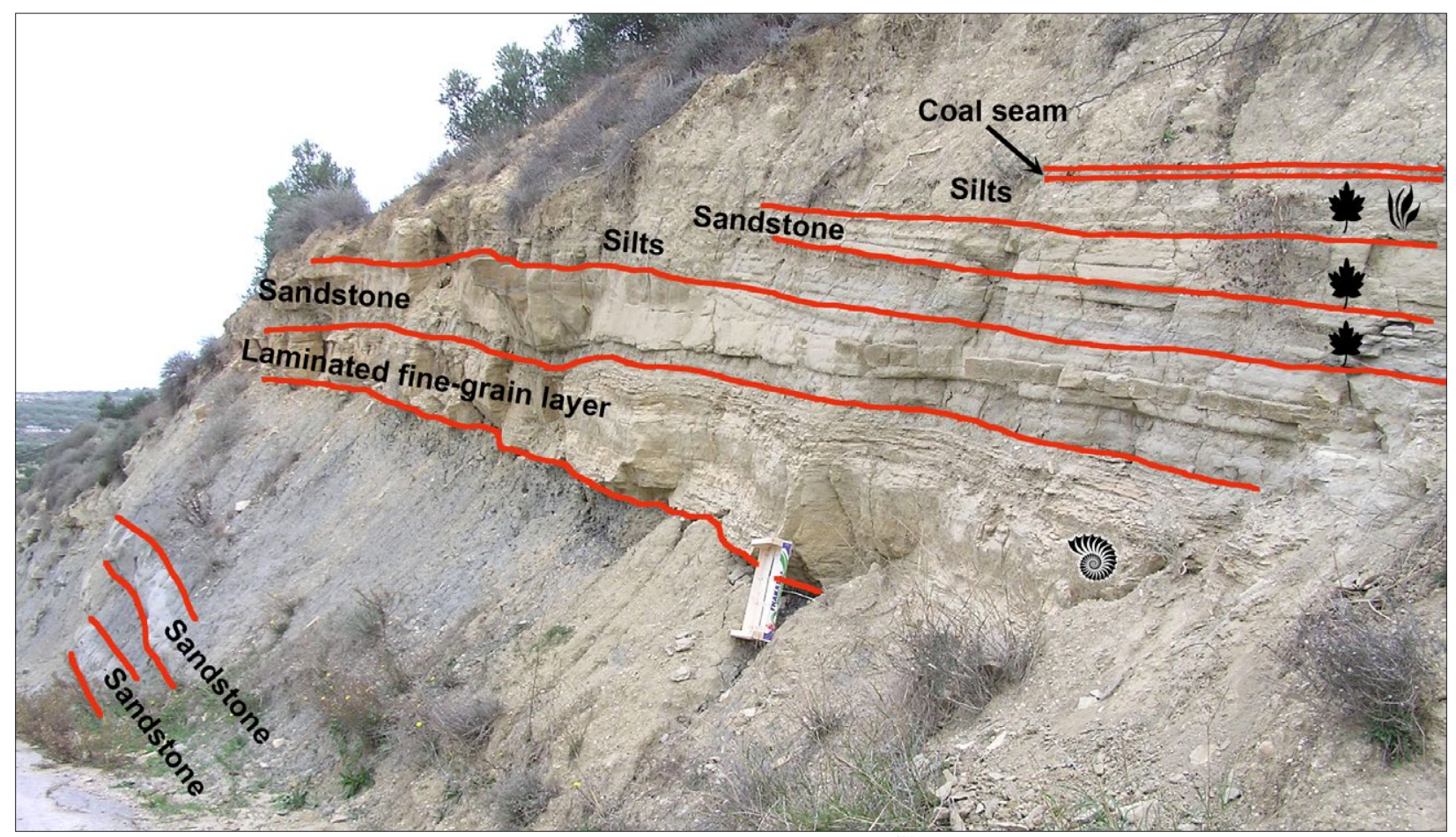

Fig. 9. Stratigraphic succession of the fossiliferous outcrop of Kassanoi;

plant macroremains, $(\%$ in situ plant roots, freshwater mollusk shells 

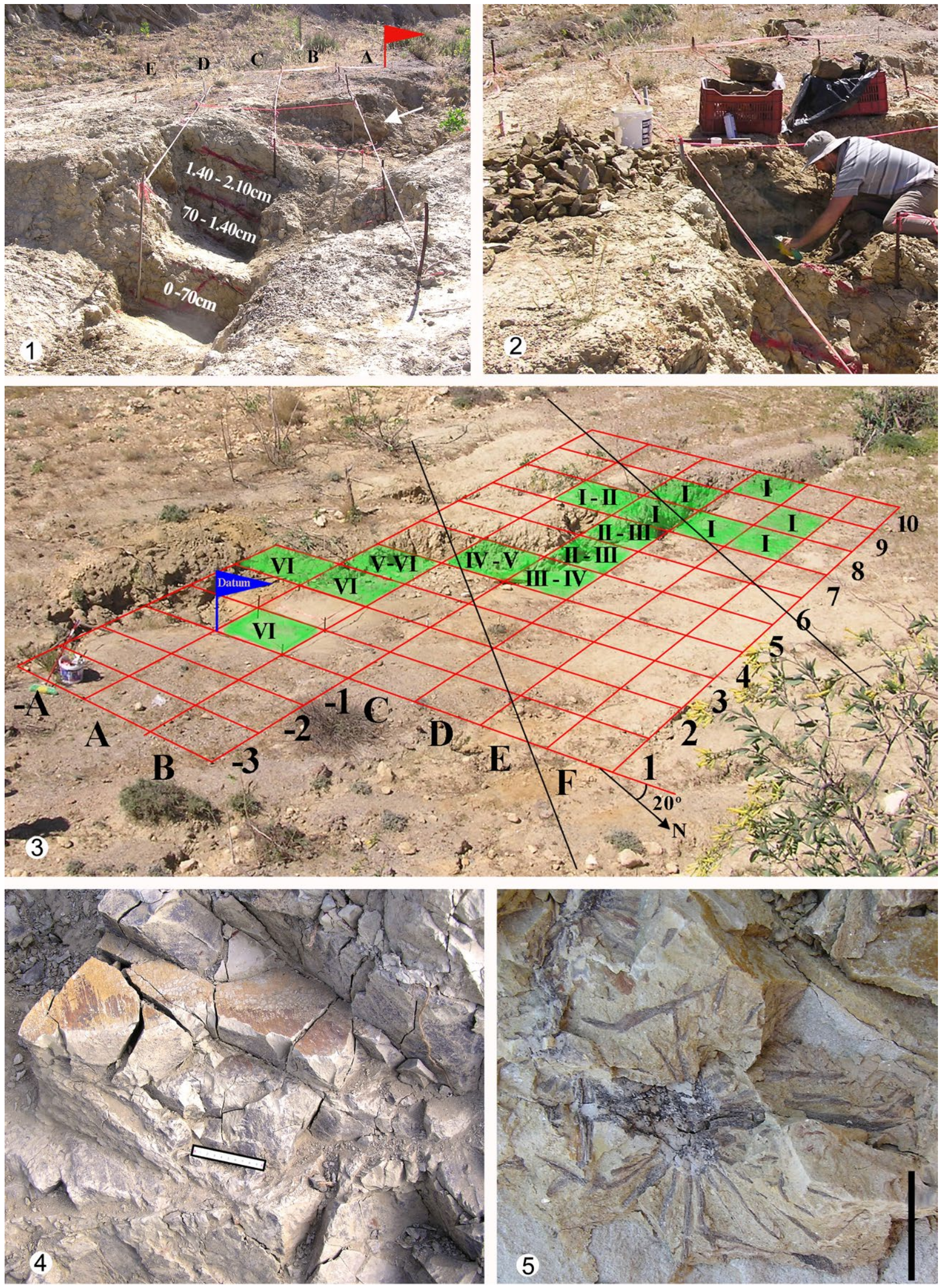

Plate 2. 1-4. Pitsidia, excavation and collection of fossil plant material; 1. the MFL is divided into 6 levels, $70 \mathrm{~cm}$ thick (flag indicates datum point, arrow indicates uppermost part of the MFL); 2. working at grid square 5C, IV level of the MFL; 3. general view of the excavation area (red lines mark the $7 \times 13 \mathrm{~m}$ grid, black lines the main exposure of the studied fossiliferous sediment, arrow indicates North and flag datum point, green the mainly excavated squares, Roman numerals show the excavated levels in each square); 4. natural fracturing of the plant-bearing deposits, scale bar = $10 \mathrm{~cm}$; $\mathbf{5}$. Kassanoi, bedding plane with in situ root remains, scale bar $=2 \mathrm{~cm}$ 
(Nrs 31.4.2.1-710, Natural History Museum of Crete). Beyond a few coalified fragments (wood and monocot foliage), the majority of the plant fossils are leaf imprints, typically of light grey, brownish or yellowish colour, showing more or less detailed leaf venation. Inflorescences and scales/bracts are common as well (Fig. 8b). Coriaceous or needle-like leaves, shoots, fruits, seeds and inflorescences are often covered by an inorganic encrustation (replica of plant tissue), showing significant micromorphological and in some cases anatomical details. Even when the plant material was freshly excavated, these encrustations often appeared weathered due to cracks in the sediment and water penetration (Pl. 2, fig. 4).

In order to record the collected specimens threedimensionally in the main fossiliferous layer, a grid of $1 \times 1 \mathrm{~m}$ squares was established, and 6 levels (I-VI), each $70 \mathrm{~cm}$ thick, were delineated (Pl. 2, figs 1-3). All recovered fossils, regardless of their size, fragmentation, quality of preservation and taxonomic value, were collected and evaluated. Only fragments of dicot leaves smaller than $\sim 1 / 6$ their original size were ignored. The density of the plant remains (excluding dicot leaves $<1 / 6$ their original size) in the main fossiliferous layer (MFL) is estimated at 5500 specimens per $\mathrm{m}^{3}$ of undamaged sediment. The dominant taxa in the assemblage, Myrica lignitum and Pinus pitsidiensis, are estimated to occur at density of $\sim 1700$ leaves and 400 dwarf shoots per $\mathrm{m}^{3}$, respectively.

The material from Kassanoi comprises 341 plant imprints on 248 slabs. They were collected from silty intercalations a few centimetres underneath the coal seam (Fig. 9). From the Metochia "sapropelic" layers, in M16-M26 sedimentary cycles, 64 slabs with 71 plant fossils (imprints) on them were collected (Fig. 10). Inorganic encrustations occurred exceptionally, mostly on defoliated shoots and needle-like leaves.

All studied material is housed in the Natural History Museum of Crete (NHMC) under collection numbers 31.4.2.800-7038 and 31.4.2.8000-8273 for Pitsidia, 31.6.2.1-248 for Kassanoi, and 31.5.2.1-64 for Metochia.

The collected specimens were examined under a Motic SMZ-168 stereoscope. Selected specimens were studied by SEM at the University of Crete (JEOL
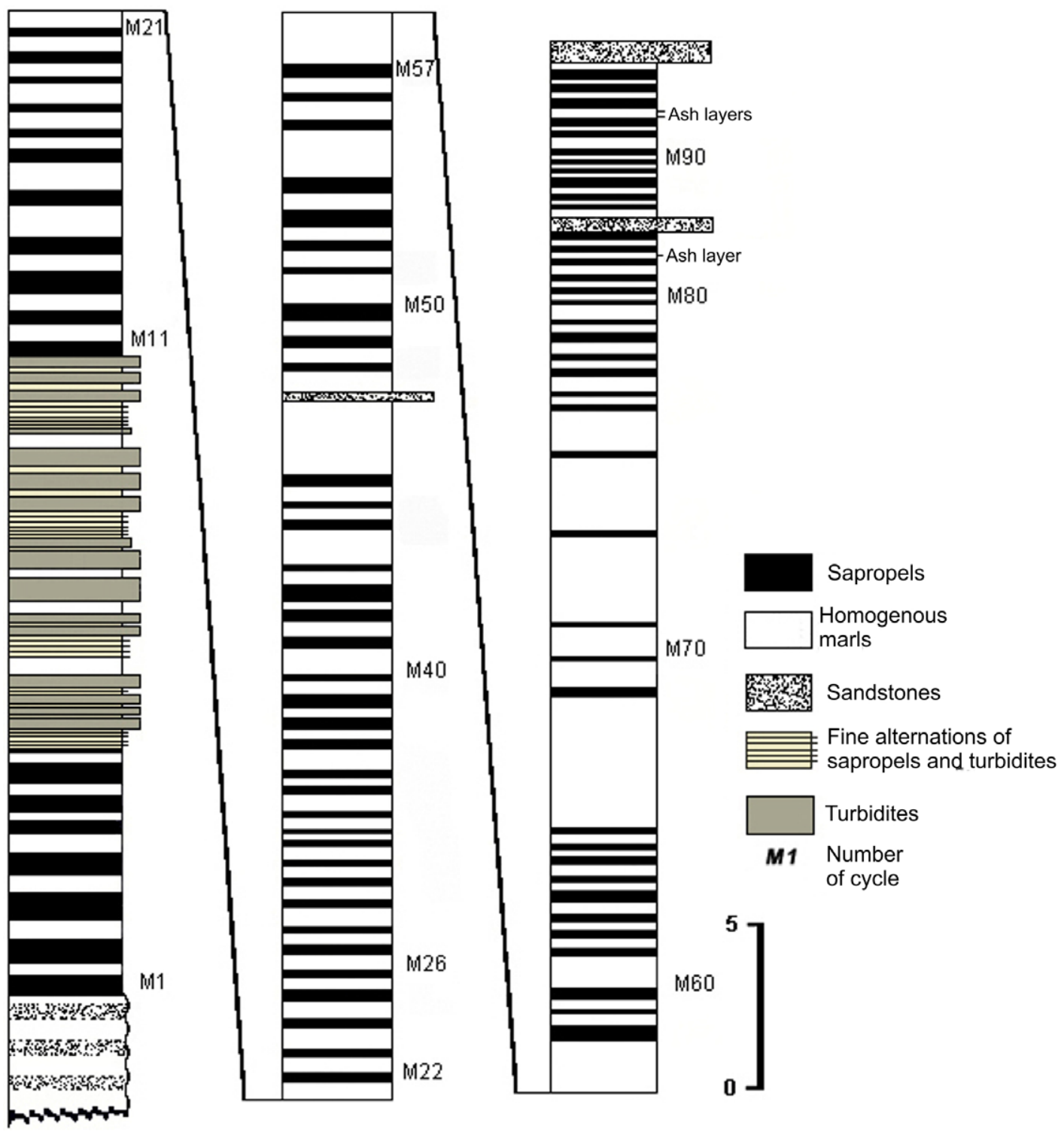

Fig. 10. Litho-stratigraphic sequence of the Metochia section (after Antonarakou, 2001) 
6390LV) and the University of Patras (JEOL 6320). Photographs were taken with a Nikon 5100 digital camera. Image adjustment and drawings employed Adobe Photoshop Software version 9.0. Identification of foliage is based on macromorphological features. For coriaceous or needle-like leaves and reproductive organs with inorganic replicas, as well as for coalified wood and monocot leaf fragments, we include micromorphological and anatomical structures. Morphological terminology for leaf architecture is based on Hickey (1973), Dilcher (1974), Ash et al. (1999) and Ellis et al. (2009). Angiosperm systematics is based on Reveal (2012), which follows the classification of APG II (Bremer et al., 2003) and III (Bremer et al., 2009). Gymnosperm and fern systematics follow Christenhusz et al. (2011) and Christenhusz, Chase (2014).

Vegetation reconstruction of the three studied plant assemblages (Kassanoi, Pitsidia and Metochia) is based on the phytosociological approach (Mai, 1995; Denk, 2016). For classification of the assemblages in terms of zonal vegetation type, we applied the Integrated Plant Record (IPR) Vegetation Analysis (Kovar-Eder, Kvaček 2007; Kovar-Eder et al., 2008; Teodoridis et al., 2011). For palaeoclimatic estimates we used two techniques: the Coexistence Approach (CA) based on interpretation of the nearest living relatives (NLR) of woody dicots (Mosbrugger and Utescher 1997; Utescher et al., 2014) and the Climate Leaf Analysis Multivariate Program (CLAMP) based on leaf physiognomy (Wolfe and Spicer, 1999; Spicer et al., 2009; Yang et al., 2011). In CA, climatic data of living relatives were retrieved from the Palaeoflora Database (Utescher and Mosbrugger, 2015). Application of CLAMP follows the procedure explained on the CLAMP website (http://clamp.ibcas.ac.cn, accessed September 2020). Datasets of physiognomic and gridded meteorological calibration collected from 189 sites were selected.

\section{SYSTEMATICS}

Due to poor preservation, the affinities of several morphotypes could not be resolved, so open nomenclature has been applied. Taxa of questionable affinity are included in "Incertae sedis", where cumulative terms such as Dicotylophyllum spp., Monocotylophyllum spp. and Antholites spp. have been used. The synonym list includes the basic references and records from Greece.

\section{Algae}

Thallus

Fam. et gen. et sp. indet.

$$
\text { Pl. 4, fig. } 1
$$

Material. Pitsidia, a thallus fragment (Nr. 31.4.2.1517a,b).
Description. Thallus filamentous, stipe (stem-like axis) $24 \mathrm{~mm}$ long and $3.5 \mathrm{~mm}$ wide, dichotomised twice.

Remarks. This specimen possibly belongs to an alga. A more accurate systematic assignment is hampered by the poor preservation. The sedimentary context implies freshwater or brackish character of this element.

$$
\text { Polypodiophyta }
$$

Polypodiales Link

Fam. indet.

\section{"Pteris" oeningensis Unger}

Pl. 3, figs 1-12; Fig. 11

1847 Pteris oeningensis Unger, p. 124, pl. 37, figs 6, 7 (Freiberg, Austria, Miocene).

?1986 Pteridium aff. aquilinum fossilis (L.) Kuhn; Velitzelos, Knobloch, pl. 12, fig. 6 (Skoura, Peloponnese, Pliocene).

?1994a Pteris cf. oeningensis Unger; Kleinhölter, pl. 14, fig. 8 (Pyrgos and Zacharo basins, Peloponnese, Messinian).

?2007a Pteridium aquilinum fossilis (L.) Kuhn; Butzmann et al., p. 23 (Vegora, W. Macedonia, Messinian) (no figure).

2010 Pteridophyta fam. indet.; Zidianakis et al., fig. 2a (Pitsidia, central Crete, Tortonian).

?2014 cf. Pteris oeningensis Unger; Velitzelos D. et al., p. 69 (Prosilio and Lava, W. Macedonia, Messinian) (no figure).

Material. Pitsidia, 47 fragments of probably bi-pinnate/pinnatifid or more divided fronds (Nrs 31.4.2.828ii; 31.4.2.979ai,bi; 31.4.2.1938; 31.4.2.1958; 31.4.2.2197i; 31.4.2.2201a,b;

31.4.2.2201aop, 2203; 31.4.2.2256;

31.4.2.2387ii; 31.4.2.3142op; 31.4.2.3496aopiii;

31.4.2.3630; 31.4.2.4082; 31.4.2.4112;

31.4.2.4179opiv; 31.4.2.4256v; 31.4.2.4302;

31.4.2.4337; 31.4.2.4376; 31.4.2.4845;

31.4.2.4846; 31.4.2.4972; 31.4.2.5027a,b;

31.4.2.5050ii; 31.4.2.5218; 31.4.2.5258a,b;

31.4.2.5372ai,bi; 31.4.2.5502; 31.4.2.5594;

31.4.2.5638; 31.4.2.5742ai; 31.4.2.5884aop;

31.4.2.5894i; 31.4.2.6079; 31.4.2.6194ii;

31.4.2.6205a,b; 31.4.2.6213; 31.4.2.6268a,bi;

31.4.2.6407iii; 31.4.2.6427bop;

31.4.2.6478aii,bii; 31.4.2.6543iii;

31.4.2.6569iii; 31.4.2.6574a,b; 31.4.2.6639;

31.4.2.6665a,b; 31.4.2.8243a,b).

Des cription. (i). Ultimate lateral segments, pinnatifid (Fig. 11c). Petiolulate, petiolule $1 \mathrm{~mm}$ 

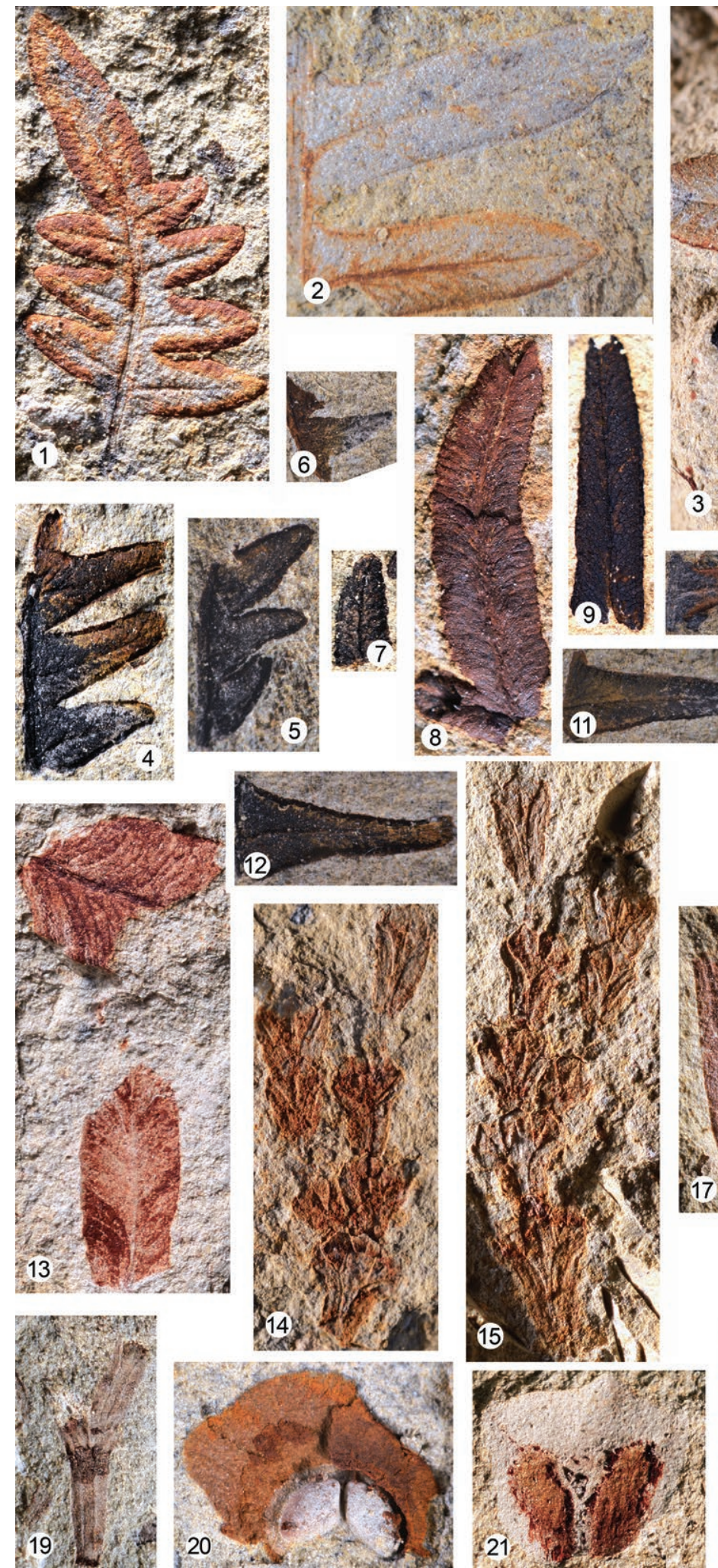

Plate 3. Cretan palaeofloras, scale bar $=5 \mathrm{~mm}$; 1-12. "Pteris" oeningensis Unger, segments, Pitsidia; 1. pinnatifid segment, Nr. 31.4.2.6268a; 2. two lateral, simple segments loosely arranged on costa, Nr. 31.4.2.6574b; 3. lateral, simple segments, Nr. 31.4.2.979bi; 4. fragment of pinnatifid segment, Nr. 31.4.2.4112; 5. fragment of pinnatifid segment, Nr. 31.4.2.5218; 6. fragment of pinnatifid segment, Nr. 31.4.2.6194ii; 7. isolated lateral lobe, Nr. 31.4.2.8243a; 8. isolated terminal segement, $\mathrm{Nr}$. 31.4.2.2197i; 9. isolated terminal segment, Nr. 31.4.2.5884aop; 10. isolated lateral lobe, Nr. 31.4.2.5894i; 11. isolated lateral lobe, Nr. 31.4.2.4846; 12. isolated lateral lobe, Nr. 31.4.2.4972; 13. Polypodiophyta fam. gen et sp. indet., two frond segments close to each other, Pitsidia, Nr. 31.4.2.2337; 14-19. Tetraclinis cf. salicornioides (Unger) Kvaček, leafy twigs; 14. Pitsidia, Nr. 31.4.2.6324b; 15. Pitsidia, Nr. 31.4.2.6324ai (counterpart of Pl. 3, fig. 14); 16. Pitsidia, Nr. 31.4.2.6331aopi; 17. solitary segment, Pitsidia, Nr. 31.4 2.845; 18. Metochia, Nr. 31.5.2.9; 19. Kassanoi, Nr. 31.6.2.182iii; 20. Gymnospermae fam. et gen. et sp. indet., ovulate scale type 2 with two seeds, Pitsidia, Nr. 31.4.2.4538bopiv; 21. Gymnospermae fam. et gen. et sp. indet., ovulate scale type 1 with scars of two seeds, Pitsidia, Nr. 31.4.2.1421aopii; 22-25. Gymnospermae fam. et gen. et sp. indet., isolated needle-like leaves, Pitsidia; 22. Nr. 31.4.2.5822ii; 23. Nr. 31.4.2.5521; 24. Nr. 31.4.2.5603; 25. Nr. 31.4.2.4439aii 
long, segment coriaceous, ovate, $11 \mathrm{~mm}$ long and $6.5 \mathrm{~mm}$ wide, lobed; lateral lobes dense, alternate to suboppositely arranged, ovate to triangular, 2-5.5 mm long and 1.5-2.5 mm wide, lobe sides convex to straight, apex acute to rounded, margin entire, \pm involute sinuses narrow, mainly angular; terminal lobe lanceolate to linear, up to $6 \mathrm{~mm}$ long and 1-2 $\mathrm{mm}$ wide; venation dichotomous, open, every lobe with a main vein arising at $45-85^{\circ}$ from midrib, straight or slightly curved, producing numerous fine veinlets, originating at acute angles, dichotomised once or twice, seldom simple (in smaller lobes), first dichotomy at the first 1/4 part of vein, ending at margin; (ii). Ultimate lateral or terminal segments, simple (Fig. 11a-b). Densely spaced, alternately to sub-oppositely arranged, lanceolate to oblong, \pm asymmetric, ultimate lateral ones bent upwards, $6-11 \mathrm{~mm}$ long and $2.5-3.5 \mathrm{~mm}$ wide, apex (bluntly) acute to rounded, margin entire to erose; venation dichotomous, open, primary vein moderate, bent, secondaries fine, dense, in $>7$ pairs, mostly forked twice,

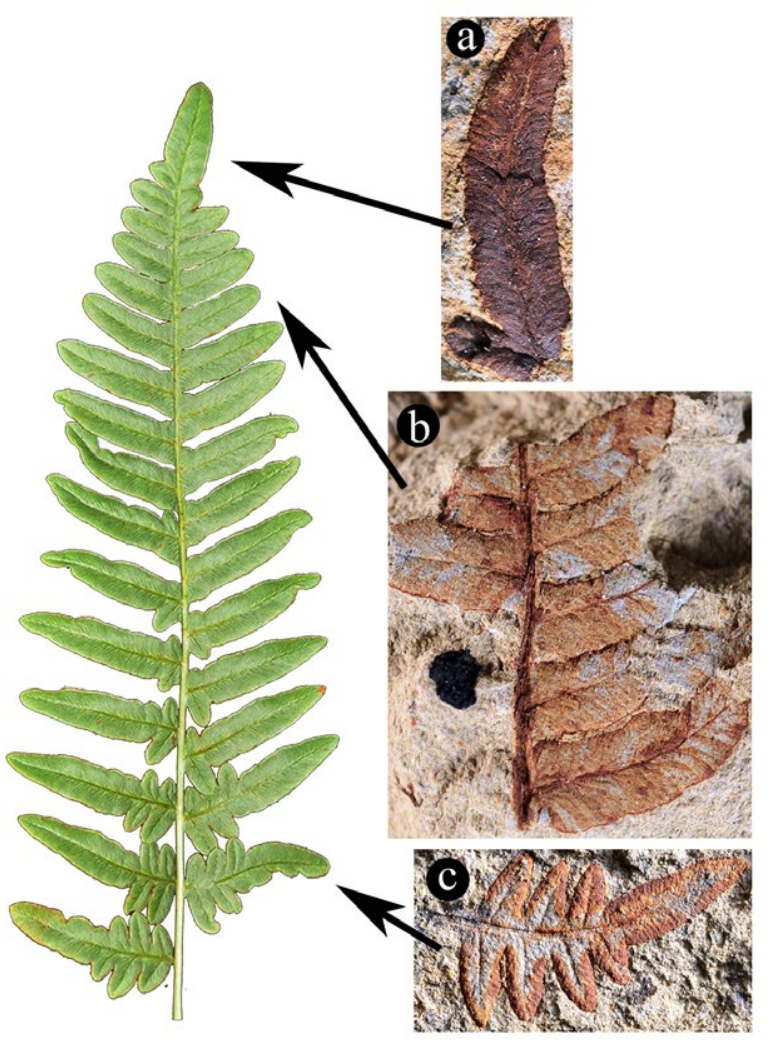

Fig. 11. Palaeoflora of Pitsidia. Schematic correlation of a pinnula of modern Pteridium aquilinum with material of "Pteris" oeningensis recovered from Pitsidia; a. ultimate terminal segment, Nr. 31.4.2.2197i; b. ultimate, lateral simple segments, Nr. 31.4.2.979bi; c. ultimate, lateral pinnatifid segment, Nr. 31.4.2.6268a first dichotomy at the first $1 / 4$ part of vein, ending at margin.

Remarks. These remains probably belong to a single fern species. As no complete frond was found, the described lateral segments most likely represent pinnulae or parts of lower division. Thus, the fronds of this fern possibly were bi- or more pinnate/pinnatifid. No fertile structures were observed, although the involute margin of the segments suggests a possible marginal arrangement for sporangia.

\section{Polypodiophyta incertae sedis}

Frond fragments type 1

Fam. et gen. et sp. indet. Pl. 3, fig. 13

Material. Pitsidia, 3 fragmentary segments (Nrs 31.4.2.1940bop; 31.4.2.2337i; 31.4.2.2337ii).

Description. Isolated, fragmentary segments, texture chartaceous, shape ovate to lanceolate, $>8 \mathrm{~mm}$ long and $3 \mathrm{~mm}$ wide, apex missing, margin entire, primary vein stout, straight, secondaries dense, originating at acute angles, bent, forked once or twice, reaching the segment margin.

Remarks. These specimens differ from "Pteris" oeningensis by the broader shape of the segment, the thinner texture, and margin which is not involute.

\section{Frond fragments type 2}

Fam. et gen. et sp. indet.

$$
\text { Pl. 4, figs 2, } 3
$$

Material. Kassanoi, 2 fragmentary fronds (Nrs 31.6.2.112; 31.6.2.161aii,bii).

Description. Fronds sterile, probably lanceolate, $>38 \mathrm{~mm}$ long and $22 \mathrm{~mm}$ wide, apex acute, entire-margined; venation dichotomous, open, primary vein strong, straight, secondary veins numerous, delicate, densely arranged, parallel, arising at $\sim 45^{\circ}$, dichotomising close to margin.

Remarks. This fern material is rare and rather fragmentary. 


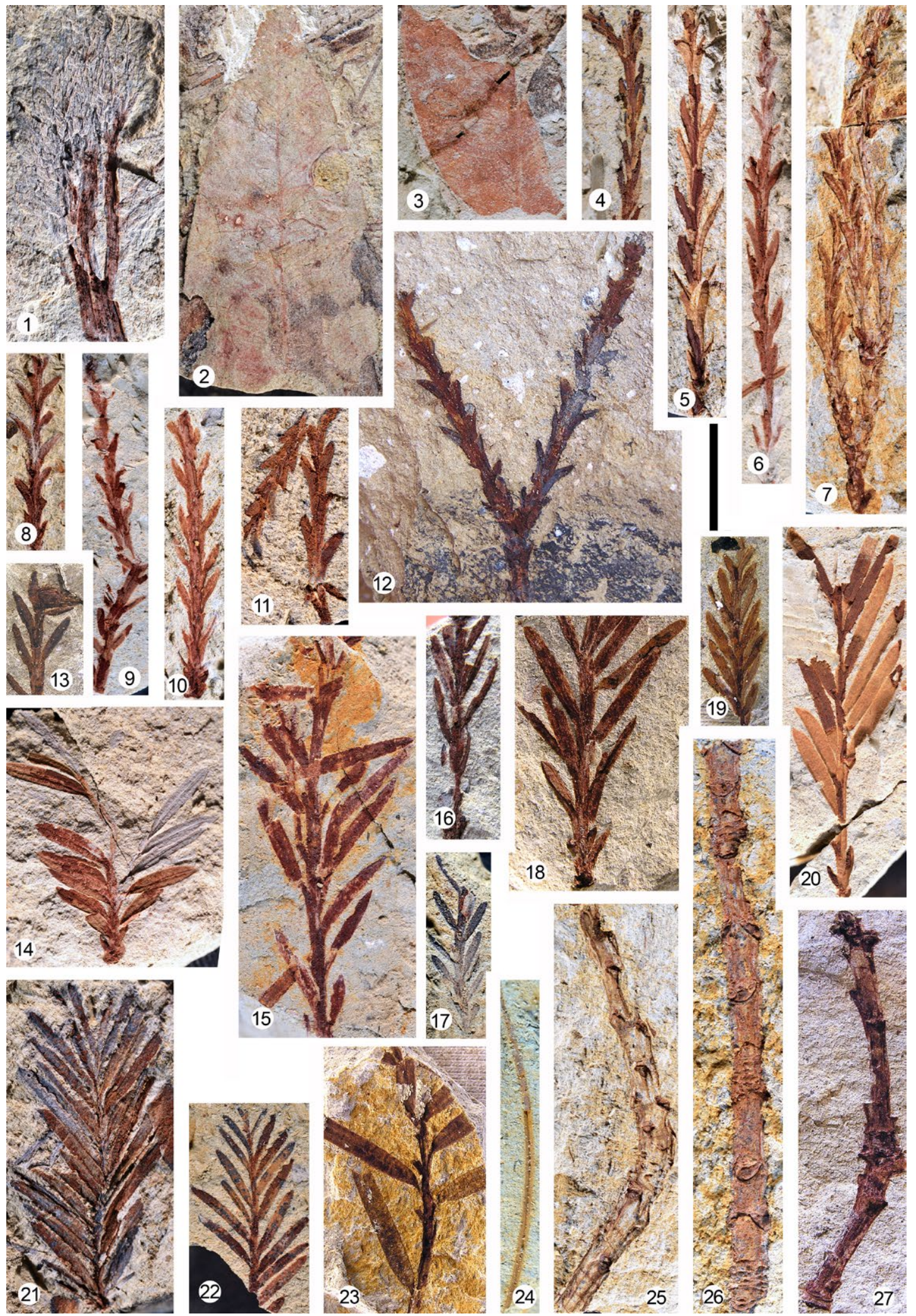

Plate 4. Cretan palaeofloras, scale bar $=1 \mathrm{~cm}$; 1. Algae, thallus fragment, Pitsidia, Nr. 31.4.2.1517b; 2, 3. Polypodiophyta fam., gen. et sp. indet., frond fragments, Kassanoi; 2. apical part, Nr. 31.6.2.161bii; 3. basal part, Nr. 31.6.2.112; 4-12. Taxodium dubium (Sternberg) Heer, foliage shoots with acicular leaves (type i), Pitsidia; 4. Nr. 31.4.2.4861aii; 5. Nr. 31.4.2.3137a; 6. Nr. 31.4.2.1217i; 7. three attached twigs, Nr. 31.4.2.6123b; 8. Nr. 31.4.2.5788ai; 9. mechanically damaged, Nr. 31.4.2.2670; 10. Nr. 31.4.2.6577a; 11. mechanically damaged, Nr. 31.4.2.4886aii; 12. dichotomised twig, Nr. 31.4.2.1135a; 13-20. Taxodium dubium (Sternberg) Heer, incomplete foliage shoots with broad needle-like leaves (type ii), Pitsidia; 13. upper part with prominent bud Nr. 31.4.2.5687; 14. Nr. 31.4.2.2158b; 15. Nr. 31.4.2.2944; 16. Nr. 31.4.2.1263; 17. Nr. 31.4.2.1260; 18. Nr. 31.4.2.4023a; 19. Nr. 31.4.2.4303a; 20. Nr. 31.4.2.2204a; 21, 22. Taxodium dubium (Sternberg) Heer, foliage shoots with slender needle-like leaves (type iii), Pitsidia; 21. Nr. 31.4.2.4137a; 22. Nr. 31.4.2.1865b; 23. Gymnospermae, fam. et gen. et sp. indet. leafy shoot, Pitsidia, Nr. 31.4.2.4290b; 24. Pinus sp. 2, five-needled, isolated needle fragment, Metochia, Nr. 31.5.2.14; 25-27. defoliated long shoots of gymnosperm origin, fam. et. gen. et sp. indet., Pitsidia; 25. Nr. 31.4.2.5049ai; 26. Nr. 31.4.2.5186; 27. Nr. 31.4.2.6463a 
Spermatophyta

Gymnospermae

Family Cupressaceae

\section{Genus Tetraclinis Masters}

\section{Tetraclinis cf. salicornioides \\ (Unger) Kvaček \\ Pl. 3, figs 14-19}

?1847 Thuites salicornioides Unger, p. 11, pl. 2, figs 1-4; pl. 20, fig. 8 (Radoboj, Croatia, Miocene).

1975 Libocedrites salicornioides (Unger) Endlicher; Heimann et al., pl. 14, fig. 6 (Paghi, Corfu Island, Messinian).

1989 Tetraclinis salicornioides (Unger); Kvaček, p. 48, pl. 1, fig. 11; pl. 2, figs 2-14; pl. 3, figs 1-4; text-fig. 1 (European Tertiary).

1993 Tetraclinis salicornioides (Unger) Kvaček; Velitzelos, pl. 2, figs 2, 3 (Nea Stira, Euboea, early Miocene).

1994a Tetraclinis salicornioides (Unger) Kvaček; Kleinhölter, pl. 1, fig. 3; pl. 15, figs 10, 11 (Pyrgos and Zacharo basins, Peloponnese, Messinian).

1996 Tetraclinis brachyodon (Brongniart) Mai et Walter; Sachse and Mohr, fig. 4.11 (Makrilia, E. Crete, Tortonian).

?2002a Tetraclinis salicornioides (Unger) Kvaček; Velitzelos et al., p. 11 (Kimi, Euboea, early Miocene) (no figure).

2004 Tetraclinis sp.; Sachse, pl. 8, figs 3, 8 (Makrilia, E. Crete, Tortonian).

2014 Tetraclinis salicornioides (Unger) Kvaček; Velitzelos D. et al., pl. 19, figs 6-8 (Elassona, N. Thessaly, Messinian).

?2014 Tetraclinis salicornioides (Unger) Kvaček; Velitzelos D. et al., p. 67 (Megalonissi, Lesbos Island, early Miocene) (no figure).

2015 Tetraclinis salicornioides (Unger) Kvaček; Mantzouka et al., figs 3.1-3.3 (Metochia, Gavdos Island, Tortonian).

M a te r i a l. Pitsidia, 2 fragmentary leafy twigs and a single isolated segment (Nrs 31.4.2.845; 31.4.2.6324ai,b; 31.4.2.6331aopi,6922opiv). Kassanoi, 2 leafy twig fragments (Nrs 31.6.2.182iii; 31.6.2.182iv). Metochia, a leafy twig (Nr. 31.5.2.9).

Description. Incomplete twigs 7 to $17 \mathrm{~mm}$ long, broad and flattened; leaves scale-like, dimorphic (facial and lateral), borne in four, fused along most of their length, forming a flattened cladode-like segment that does not overlap with adjacent ones; whorls cuneiform or narrow elongate, $2.0-7.5 \mathrm{~mm}$ long and 1-3 $\mathrm{mm}$ wide, with rounded to truncate base; facial leaves closely appressed with acute apex, lateral leaves linear, overlapping margins of facial leaves, mostly free-tipped, shorter than facial leaves, apex acute, slightly incurved; three or five veins occur on each whorl according to their position.

Re marks. According to Kvaček et al. (2000), two different species of Tetraclinis can be distinguished in the European Paleogene/Neogene, T. brachyodon (Brongniart) Mai et Walther and T. salicornioides, though some authors argue for the existence of a single species (e.g. Ferguson et al., 1998; Mai, 1998). Morphologically, these species differ mainly in the bract morphology of the seed cone, stomata distribution, branching, and to a lesser degree segment morphology and leaf fusion completion. Only the segment morphology is available in the material studied here. In Pitsidia and Metochia, the foliage fusion seems to be quite complete and the segments are more or less broad, isomorphic. These features allowed the assignment to T. salicornioides. Mantzouka et al. (2015) reported 1 twig and 2 detached leafy segments of T. salicornioides from Metochia. Vrysses is the only Cretan locality where T. brachyodon has been documented (Zidianakis et al., 2007, as Tetraclinis sp.). T. salicornioides is regarded as a frequent accessory element of subtropical to warm-temperate mesophytic forests (Kvaček, 1989; Mai, 1994; Kvaček et al., 2000).

\section{Genus Taxodium L.C. Richard}

\section{Taxodium dubium (Sternberg) Heer}

$$
\text { Pl. 4, figs 4-22 }
$$

1823 Pyllites dubius Sternberg, p. 37, pl. 36, fig. 3, tentamen and index (Bílina, Czech Republic, early Miocene).

1855 Taxodium dubium (Sternberg) Heer; Heer, pp. 49-50, pl. 17, figs 5-15 (Hohe Rhonen, Switzerland, late Miocene).

?1867 Sequoia langsdorfii (Brongniart) Heer; Unger, pl. 2, figs 22, 23 (Kimi, Euboea, early Miocene).

1975 Taxodium dubium (Sternberg) Heer; Heimann et al., pl. 14, fig. 4 (Paghi, Corfu Island, Messinian).

?1977 Sequoia langsdorfii (Brongniart) Heer; Velitzelos, Schneider, fig. 4 (Vegora, W. Macedonia, Messinian).

?1983 Taxodium vel. Sequoia spec.; Velitzelos, pl. 1, figs 1, 6 (Pappades, Euboea, late Miocene).

?1994a Taxodium sp.; Kleinhölter, pl. 1, fig. 4; pl. 15, fig. 13 (Pyrgos and Zacharo basins, Peloponnese, Messinian). 
1996 Taxodium dubium (Sternberg) Heer; Sachse, Mohr, fig. 4.10 (Makrilia, E. Crete, Tortonian).

1998 Taxodium dubium (Sternberg) Heer; Velitzelos et al., pl. 7, fig. 1 (Vegora, W. Macedonia, Messinian)

2002 Taxodium dubium (Sternberg) Heer; Kvaček et al., pl. 1, figs 7, 8; pl. 27, fig. 4 (Vegora, W. Macedonia, Messinian).

2004 Taxodium dubium (Sternberg) Heer; Sachse, pl. 8, fig. 7 (Makrilia, E. Crete, Tortonian).

?2007b Taxodium dubium (Sternberg) Heer; Butzmann et al., p. 25 (Fylakton, Thrace, Oligocene) (no figure).

2010 Taxodium sp.; Zidianakis et al., fig. 2d (Pitsidia, central Crete, Tortonian).

2014 Taxodium dubium (Sternberg) Heer; Velitzelos D. et al., p. 69, pl. 16, figs 3-5 (Prosilio and Lava, W. Macedonia, Messinian).

?2014 Taxodium vel Sequoia; Velitzelos D. et al., pl. 8, fig. 2 (Kimi, Euboea, early Miocene).

2015 Taxodium dubium (Sternberg) Heer, Mantzouka et al., fig. 3.4 (Metochia, Gavdos Island, Tortonian).

Material. Pitsidia, 82 leafy shoots or shoot fragments (Nrs 31.4.2.832a,b; 31.4.2.974; 31.4.2.988ii; 31.4.2.988iv; 31.4.2.1020ai,bi; 31.4.2.1021; 31.4.2.1106; 31.4.2.1121a,b; 31.4.2.1135a,b; 31.4.2.1217i; 31.4.2.1222ai,bi; 31.4.2.1230; 31.4.2.1260; 31.4.2.1263,6884i; 31.4.2.1265; 31.4.2.1408opii; 31.4.2.1865a,b; 31.4.2.1930a,b; 31.4.2.2158a,b; 31.4.2.2204a,b; 31.4.2.2281ai,bi; 31.4.2.2314a,b;

31.4.2.2442a,b; 31.4.2.2446a,b; 31.4.2.2636;

31.4.2.2647i; 31.4.2.2670; 31.4.2.2709;

31.4.2.2717op; 31.4.2.2727,2714op;

31.4.2.2739aiv; 31.4.2.2753; 31.4.2.2818;

31.4.2.2944; 31.4.2.2963a,b; 31.4.2.3036;

31.4.2.3137a,b; 31.4.2.3150avi,3158;

31.4.2.3223; 31.4.2.3372vii; 31.4.2.3589aiii;

31.4.2.3614a,b; 31.4.2.3842a,b; 31.4.2.3907a,b;

31.4.2.4023a,b; 31.4.2.4137a,bi;

31.4.2.4303a,b; 31.4.2.4455; 31.4.2.4468ai,b;

31.4.2.4540ai,bi; 31.4.2.4540aii,bii;

31.4.2.4683; 31.4.2.4856; 31.4.2.4861aii,bii;

31.4.2.4886aii,b; 31.4.2.4888; 31.4.2.4906a,b;

31.4.2.4946iii; 31.4.2.4991a,b; 31.4.2.4993a,b;

31.4.2.5307; 31.4.2.5640; 31.4.2.5687;

31.4.2.5744a,b; 31.4.2.5747; 31.4.2.5788ai,b;

31.4.2.5979; 31.4.2.6059i,6050op;

31.4.2.6123a,b; 31.4.2.6124a,b;

31.4.2.6235; 31.4.2.6388a,b; 31.4.2.6577a,b;

31.4.2.6872aop; 31.4.2.6881; 31.4.2.6885;

31.4.2.6955; 31.4.2.8139iii; 31.4.2.8156aiii;

31.4.2.8223a,b; 31.4.2.8224i; 31.4.2.8235ai,bi).

Description. Leafy shoots with helically arranged leaves. They can be separated into three different shoot types according to leaf size and spreading:

Type (i). shoots $\sim 45-55 \mathrm{~mm}$ long, with short, acicular to slightly subulate, bifacial leaves, \pm appressed, 3-7 $\mathrm{mm}$ long and $\sim 0.5 \mathrm{~mm}$ wide, spreading three-dimensionally, angles between shoot and leaf axes $\sim 25-40^{\circ}$ (this type of shoot prevails in the assemblage),

Type (ii). shoots $>30 \mathrm{~mm}$ long, with flattened, bifacial needle-like leaves, straight, 7-13 mm long and 0.8-1.2 mm wide, originating at $25-40^{\circ}$, spreading in one plane (distichously), needle base twisted, somewhat decurrent, needle tapering into an acute needle apex, margin entire; mid-vein strong, distinct; needles longer near the middle part of the short shoot or below, decreasing in length and width towards apex.

Type (iii). Shoots quite similar to second type but needles slender, somewhat longer, occasionally curved, originating at more open angles $\left(35-50^{\circ}\right)$, apex sometimes mucronate.

In cross section, inorganic replicas of the needles show a prominent vascular bundle but no resin ducts were detected. Stomatal structures are not preserved.

R e m a rks. Sterile shoots with needle-like, helically inserted and distichously arranged leaves occur in three genera of the Cupressaceae, in Glyptostrobus, Sequoia and Taxodium. The narrow shape of the needles, tapering towards the apex, and the position of the longest needles at the middle part of the short shoots are features that match better with Taxodium (Kunzmann et al., 2009) than with the other taxa. Remarkably, no fertile structures of Taxodium dubium were encountered in Pitsidia, although twig fragments are rather common. This may indicate parautochthonous to allochthonous origin. From Crete, a few incomplete shoots of T. dubium have also been reported from Makrilia and Metochia (Sachse, 2004; Mantzouka et al., 2015).

\section{Family Pinaceae \\ Genus Pinus L.}

\section{Subgenus: Pinus L.}

For Pinus pitsidiensis Zidianakis, Iliopoulos, Zelilidis et Kovar-Eder, Pinus sp. - twoneedled fascicles, Pinus sp. - fascicle bracts, and Pinus sp. 1 - ovulate cone scales we refer to Zidianakis et al. (2016). 


\section{Subgenus Strobus Lemmon}

For Pinus sp. 1 - five-needled fascicles we refer to Zidianakis et al. (2016).

Pinus sp. 2 - five-needled fascicle

$$
\text { Pl. 4, fig. } 24
$$

Material. Metochia, one needle fragment (Nr. 31.5.2.14).

Des c riptio n. Needle fragment, $31 \mathrm{~mm}$ long, $0.7-0.8 \mathrm{~mm}$ wide, $\sim 0.3-0.4 \mathrm{~mm}$ high, needle shape narrow flabellate in cross-section, abaxially profoundly medial-keeled, margin entire; amphistomatic, stomata in well-defined longitudinally arranged rows; rows six abaxially, irregularly spaced, stomata regularly spaced within rows, 14-16 per $1 \mathrm{~mm}$.

Remarks. The original length of this needle is unknown. The flabellate shape in cross section indicates a five-needled pine species.
Pinus sp. 2 - ovulate cone scale, see Zidianakis et al. (2016)

Not assignable to a specific subgenus: Pinus sp. 1 - fully developed seeds, Pinus sp. 2 - fully developed seeds, Pinus sp. - underdeveloped seeds, Pinus sp. 1 - pollen cones, Pinus sp. 2 pollen cones, Pinus sp. - bud scales, see all in Zidianakis et al. (2016).

Pinaceae, gen. et sp. indet. - coalified wood

Fig. 12

Material. Pitsidia, one wood fragment (Nr. 31.4.2.7011).

Description. Small fragment of wood, coalified; in transverse section, growth ring boundaries distinct, composed of axial earlyand latewood tracheids, earlywood tracheids angular, pentagonal to hexagonal, occasionally roundish, transition from early- to latewood
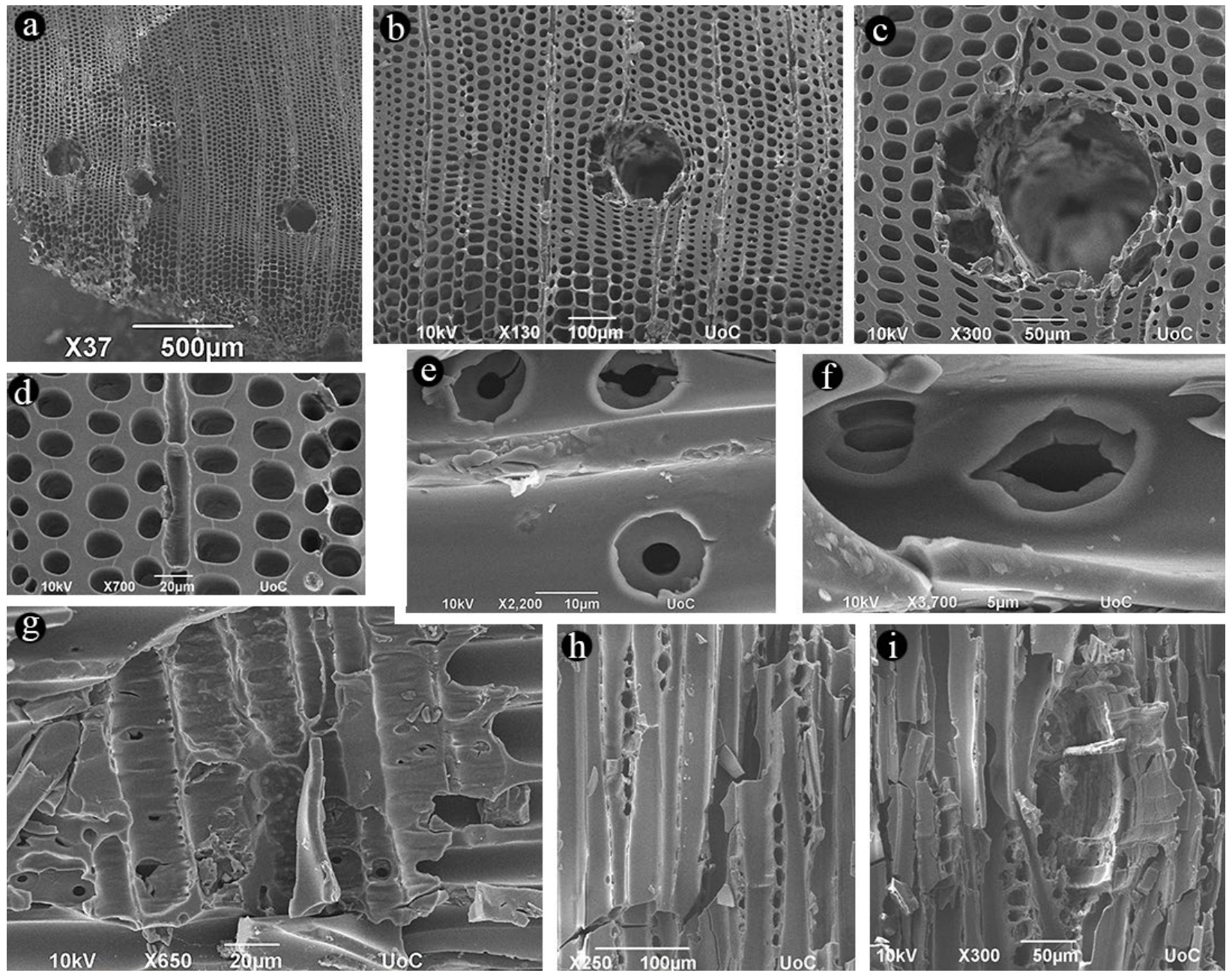

Fig. 12. Palaeoflora of Pitsidia. Anatomy of a coalified wood fragment, SEM, Nr. 31.4.2.7011; a. growth ring and axial resin canals, transverse section; b. gradual transition from earlywood to latewood, transverse section; c. normal axial intercellular resin canals, transverse section; d. latewood axial tracheids and radial parenchyma, transverse section; e. cross field of radial parenchyma and axial tracheids, radial section; f. pitting in radial walls of earlywood tracheids, radial section; g. cross-field pitting, radial section; $\mathbf{h}$. uniseriate rays, tangential section; i. horizontal resin canal, tangential section 
gradual, latewood tracheids thick-walled, axial parenchyma not found, normal axial intercellular resin canals present, epithelial cells not preserved; in radial section, pitting in radial walls of earlywood tracheids predominantly uni-seriate, cross-field pitting pinoid to cupressoid; in tangential section, rays exclusively uni-seriate, ray height medium (9-10 cells), horizontal intercellular resin canals present.

Remarks. The wood structure is homogeneous, composed of tracheids with distinct growth ring boundaries. It is therefore assigned to the conifers (Watson and Dallwitz, 2008). The presence of resin ducts accounts for the assignment to the Pinaceae (Young and Watson, 1969). Among modern members of Pinaceae, both axial and horizontal normal resin ducts occur in the genera Cathaya, Larix, Picea, Pinus and Pseudotsuga (Lin et al., 2000; Estenban and De Palacios, 2009).

Gymnospermae incertae sedis

Leafy shoot

Fam. et gen. et sp. indet.

Pl. 4, fig. 23

M a t e ri a l. Pitsidia, a fragmentary leafy shoot (Nr. 31.4.2.4290a,b).

Description. Isolated shoot $30 \mathrm{~mm}$ long, attached leaves linear, $15 \mathrm{~mm}$ long, incomplete, and $2 \mathrm{~mm}$ wide, helically arranged, originating at acute angles, severely twisted basally, forming a pseudo-petiole, leaf apex missing, margin entire, mid-vein moderately thick.

Remarks. The shape of the attached leaves suggests a gymnosperm affinity for this specimen. It is not included in Taxodium dubium because of the broader needles.

\section{Defoliated long shoots}

Fam. et gen. et sp. indet.

$$
\text { Pl. 4, figs 25-27 }
$$

Material. Pitsidia, at least 4 fragmentary long shoots (Nrs 31.4.2.5049ai,b; 31.4.2.5186; 31.4.2.6270i,6243ii; 31.4.2.6463a,b).

Description. Defoliated shoots $38-54 \mathrm{~mm}$ long, nodes surrounded by numerous densely spaced scars of bud scales, internodes with helically arranged large scars of abscised leaves.

Remarks. The type of scars and their arrangement on the shoots suggest a gymnosperm origin for these specimens.

Needle-like leaves

Fam. et gen. et sp. indet.

Pl. 3, figs $22-25$

Material. Pitsidia, 3 complete needlelike leaves and an almost complete one (Nrs 31.4.2.4439aii,bii; 31.4.2.5521; 31.4.2.5603; 31.4.2.5822ii).

Description. Isolated needle-like leaves, sessile (no petiole), linear to lanceolate, 7-11 mm long and 1-2 mm wide, apex acute, base rounded to truncate, margin entire, midvein strong and straight.

Remarks. This material comprises various kinds of needles that are not easily identifiable due to the lack of diagnostic features. A Pinaceae or/and Cupressaceae origin is likely. Some of them (e.g., Pl. 3, figs 24, 25) may represent juvenile (primary) leaves of Pinus, because pine needles occur massively in the assemblage of Pitsidia.

Ovulate cone scale type 1

Fam. et gen. et sp. indet.

Pl. 3, fig. 21

Material. Pitsidia, a complete ovulate scale of a seed cone (Nr. 31.4.2.1421aopii).

Description. Isolated cup-like scale, $5 \mathrm{~mm}$ long and $5 \mathrm{~mm}$ wide, base asymmetric, rounded, apex shortly acuminate, with two seeds positioned proximally; seeds elliptic, $2.5 \mathrm{~mm}$ long and $1.0 \mathrm{~mm}$ wide, with rounded ends.

R e m arks. The lack of diagnostic features prevents a more precise systematic assignment.

Ovulate cone scale type 2

Fam. et gen. et sp. indet.

$$
\text { Pl. 3, fig. } 20
$$

Material. Pitsidia, one incomplete ovulate scale of a seed cone (Nr. 31.4.2.4538bopiv). 
Description. Scale broadly ovate, $5 \mathrm{~mm}$ long and $\sim 9 \mathrm{~mm}$ wide (when completed), apex rounded, with two seeds at base; seeds oval to elliptic, 2-2.5 $\mathrm{mm}$ long and 1-1.5 mm wide.

Remarks. This specimen could be of coniferous origin.

\section{Angiospermae}

Family Lauraceae

\section{Genus Daphnogene Unger}

\section{Daphnogene polymorpha}

(A. Braun) Ettingshausen

Pl. 5, figs 1-15

1845 Ceanothus polymorphus A. Braun, p. 171 (Öhningen, Germany, middle Miocene).

1851 Daphnogene polymorpha (A. Braun) Ettingshausen; Ettingshausen, p. 16, pl. 2, figs 23-25 (Hernals, Austria, middle Miocene).

1867 Cinnamomum lanceolatum Unger; Unger, pl. 7, figs 1-10 (Kimi, Euboea, early Miocene).

1867 Cinnamomum scheuchzeri Heer; Unger, pl. 7, figs 11-24 (Kimi, Euboea, early Miocene).

1867 Cinnamomum subrotundum Heer; Unger, pl. 7, figs 25-29, (not 30) (Kimi, Euboea, early Miocene).

1867 Bauhinia olympica Unger; Unger, pl. 15, fig. 36 (Kimi, Euboea, early Miocene).

?1873 Litsea Delphica Saporta; Saporta, pl. 2, fig. 7b (Kimi, Euboea, early Miocene).

1953 Cinnamomum polymorphum (A. Braun) Frentz.; Berger, fig. 6 (Kastron, Lemnos Island, early Miocene).

1953 Daphnogene lanceolata Unger; Berger, figs 7-11 (Kastron, Lemnos Island, early Miocene).

1953 Cinnamomum polymorphum A. Braun; Berger, fig. 18 (Moudros, Lemnos Island, early Miocene).

1953 Cinnamomum cf. scheuchzeri (Heer) Frentz.; Berger, figs 19, 20 (Moudros, Lemnos Island, early Miocene).

1981 Cinnamomum polymorphum Heer; Velitzelos, Petrescu pl. 2, figs 1-8 (Lesbos Island, early Miocene).

?1984 Cinnamomum lanceolatum Heer; Velitzelos, Gregor, p. 242 (Aliveri, Euboea, early Miocene) (no figure).

?1985 Cinnamomum polymorphum Heer; Dermitzakis, Velitzelos, p. 165 (Kato Komi, Chios Island, Serravallian-Tortonian) (no figure).

1992 Daphnogene polymorpha (A. Braun) Ettingshausen; Velitzelos et al., pl. 6, figs 6, 7(Aliveri, Euboea, early Miocene).

1993 Daphnogene polymorpha (A. Braun) Ettingshausen; Velitzelos, pl. 3, fig. 1 (Moudros, Lemnos Island, early Miocene).

1993-95 Cinnamomum polymorphum Kräusel,
Weyland; Schimani, Schneider, figs 3, 4 (not 5) (Platanos-Paliopyrgos, Thessaly, early Miocene).

1994a Daphnogene polymorpha (A. Braun) Ettingshausen, Kleinhölter, pl. 1, fig. 8; pl. 18, figs 1, 2 (Pyrgos and Zacharo basins, Peloponnese, Messinian).

1997 Daphnogene polymorpha (A. Braun) Ettingshausen; Erdei, Kvaček, fig. 6 (Kimi, Euboea, early Miocene).

1999 Daphnogene polymorpha (A. Braun) Ettingshausen; Velitzelos et al., fig. E7 in p. 461 (Kimi, Euboea, early Miocene).

2004 fgen. Cinnamomophyllum sp.; Sachse, pl. 11, figs 7, 8 (Makrilia, E. Crete, Tortonian).

Non 2004 fsp. Cinnamomophyllum polymorphum (A. Braun) Heer; Sachse, pl. 11, fig. 12 (Makrilia, E. Crete, Tortonian).

2007 Daphnogene polymorpha (A. Braun) Ettingshausen; Zidianakis et al., figs 2E, 5D (Vrysses, W. Crete, Messinian)

2010 Daphnogene polymorpha (A. Braun) Ettingshausen; Zidianakis et al., fig. 3a (Pitsidia, central Crete, Tortonian).

2014 Daphnogene polymorpha (A. Braun) Ettingshausen; Velitzelos D. et al., pl. 7, fig. 3 (Grevena, W. Macedonia, early Miocene).

2014 Daphnogene polymorpha (A. Braun) Ettingshausen; Velitzelos D. et al., pl. 9, figs 9-?10 (Kimi, Euboea, early Miocene).

2014 Daphnogene polymorpha (A. Braun) Ettingshausen; Velitzelos D. et al., pl. 13, figs 1, 2 (Lesbos Island, early Miocene).

2014 Daphnogene polymorpha (A. Braun) Ettingshausen; Velitzelos D. et al., pl. 14, fig. 3 (Lemnos Island, early Miocene).

?2014 Daphnogene polymorpha (A. Braun) Ettingshausen; Velitzelos D. et al., p. 73 (Zyfia, Chios Island, middle Miocene) (no figure).

2015 Daphnogene sp.; Mantzouka et al., figs 3.103.12 (Metochia, Gavdos Island, Tortonian).

Material. Pitsidia, 11 complete or almost complete leaves and 58 fragmentary leaves (Nrs 31.4.2.843; 31.4.2.893a,b;

31.4.2.978i; 31.4.2.1096; 31.4.2.1105a,b;

31.4.2.1146a,b; 31.4.2.1166; 31.4.2.1286iii;

31.4.2.1303; 31.4.2.1380op; 31.4.2.1672;

31.4.2.1863a,b; 31.4.2.1919; 31.4.2.2467aii,c;

31.4.2.2718; 31.4.2.3100a,b; 31.4.2.3280;

31.4.2.3572aopii,3558ii; 31.4.2.3627ai,bi;

31.4.2.3652; 31.4.2.3670; 31.4.2.3696aii,bii;

31.4.2.3737a,b; 31.4.2.3799; 31.4.2.3824,3823op;

31.4.2.4102ai,b; 31.4.2.4233i,4227opi;

31.4.2.4246; 31.4.2.4364a,b; 31.4.2.4538ai,b;

31.4.2.4740a,b; 31.4.2.5131bii; 31.4.2.5180;

31.4.2.5255; 31.4.2.5444; 31.4.2.5466aiv,biv;

31.4.2.5499ai,b; 31.4.2.5566op; 31.4.2.5584op;

31.4.2.5630; 31.4.2.5697aopiii; 31.4.2.5713;

31.4.2.5785aiv,biv; 31.4.2.5791,5743bop;

31.4.2.5806bopii; 31.4.2.5811ai,bi; 

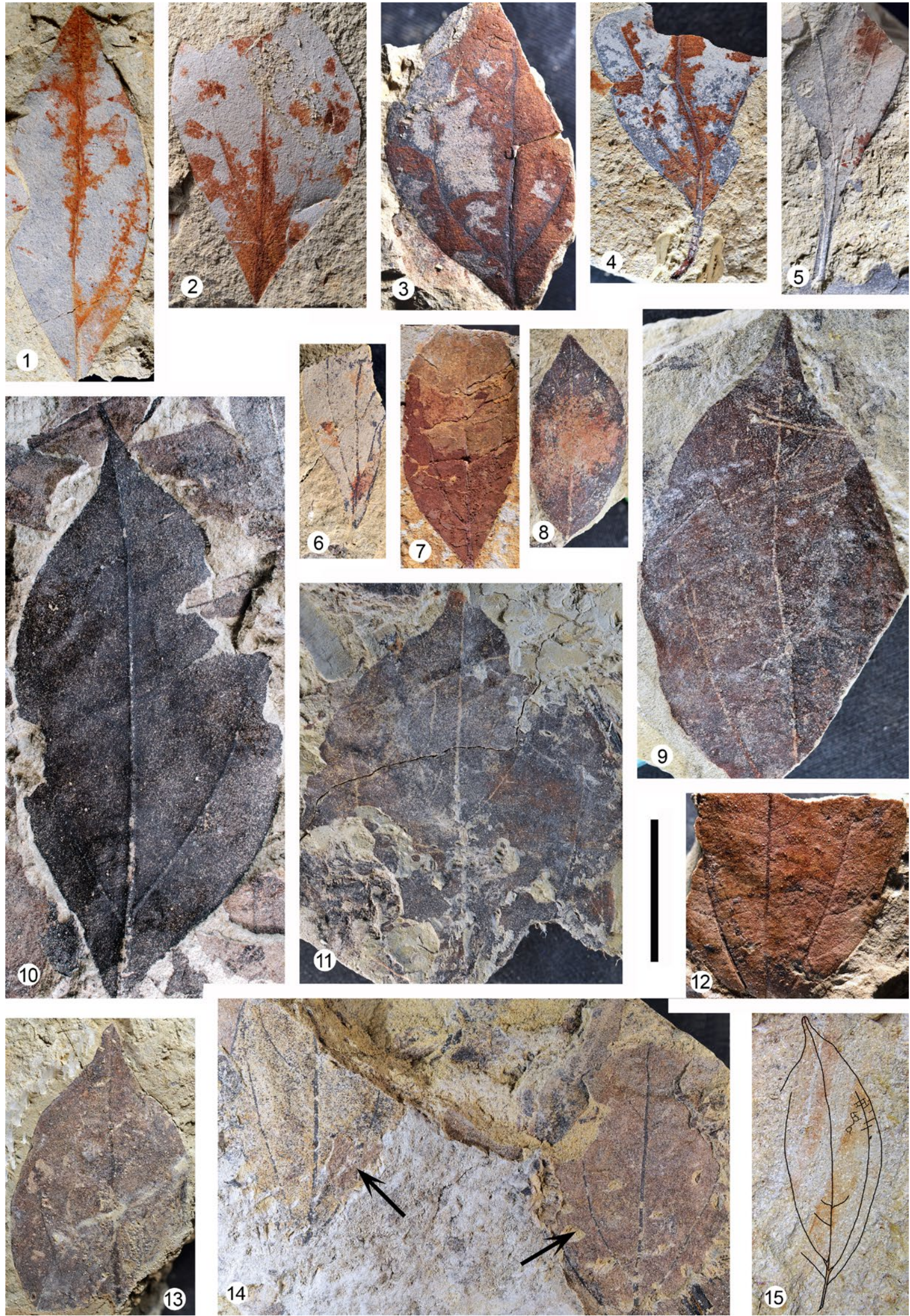

Plate 5. Cretan palaeofloras, scale bar $=2 \mathrm{~cm} ; \mathbf{1 - 1 5}$. Daphnogene polymorpha (A. Braun) Ettingshausen, foliage; 1. Pitsidia, Nr. 31.4.2.5466aiv; 2. Pitsidia, Nr. 31.4.2.4538ai; 3. Pitsidia, Nr. 31.4.2.1863b; 4. leaf base, Pitsidia, Nr. 31.4.2.4364a; 5. leaf base, Pitsidia, Nr. 31.4.2.5785biv; 6. Pitsidia, Nr. 31.4.2.3737b; 7. Pitsidia, Nr. 31.4.2.4102b; 8. small leaf, Kassanoi, Nr. 31.6.2.147; 9. Kassanoi, Nr. 31.6.2.136; 10. Kassanoi, Nr. 31.6.2.122; 11. Kassanoi, Nr. 31.6.2.125; 12. leaf base, Kassanoi, Nr. 31.6.2.138i; 13. Kassanoi, Nr. 31.6.2.131; 14. slab with two leaves (arrows), Kassanoi, Nr. 31.6.2.126; 15. petiole, lamina margin and venation are partly lined, Metochia, Nr. 31.5.2.31a 
31.4.2.5845a,b; 31.4.2.6260ii;

31.4.2.6270ii,6243iii; 31.4.2.6306; 31.4.2.6317;

31.4.2.6496; 31.4.2.6519; 31.4.2.6537;

31.4.2.6718; 31.4.2.6789; 31.4.2.6790;

31.4.2.6794; 31.4.2.6940i; 31.4.2.6944a,b;

31.4.2.6988; 31.4.2.6951a,bi; 31.4.2.8108;

31.4.2.8161; 31.4.2.8180; 31.4.2.8215;

31.4.2.8208ai,bi; 31.4.2.8208aii; 31.4.2.8190).

Kassanoi, 5 complete or almost complete leaves and 37 fragmentary ones (Nrs 31.6.2.29ii;

31.6.2.113ii; 31.6.2.120v; 31.6.2.122; 31.6.2.123i;

31.6.2.124i; 31.6.2.125; 31.6.2.126i; 31.6.2.126ii;

31.6.2.128i,135i; 31.6.2.128ii,135ii; 31.6.2.128iii;

31.6.2.128iv; 31.6.2.129; 31.6.2.130i;

31.6.2.130ii; 31.6.2.131; 31.6.2.132; 31.6.2.133;

31.6.2.136; 31.6.2.137a,b; 31.6.2.138i,155;

31.6.2.139; 31.6.2.140; 31.6.2.142; 31.6.2.143;

31.6.2.144; 31.6.2.145; 31.6.2.146; 31.6.2.147;

31.6.2.148; 31.6.2.149; 31.6.2.150; 31.6.2.151i;

31.6.2.152i; 31.6.2.153; 31.6.2.154; 31.6.2.156;

31.6.2.170i; 31.6.2.174; 31.6.2.180ii; 31.6.2.221).

Metochia, one complete leaf (Nr. 31.5.2.31a,b).

Des c ription. Leaves petiolate, petiole robust, $8 \mathrm{~mm}$ to $>14 \mathrm{~mm}$ long, mostly incompletely preserved; lamina polymorphic in shape, coriaceous, mostly ovate, elliptic to obovate, rarely lanceolate 24-95 mm long and $10-50 \mathrm{~mm}$ wide, $\mathrm{L} / \mathrm{W}$ ratio 1.7-2.6, base angle acute, rarely obtuse, variable in shape from cuneate to convex or less frequently rounded or decurrent, occasionally slightly asymmetric, apex acute to acuminate, margin entire; venation suprabasal acrodromous, central primary vein stout, usually gently curved apically or throughout its length, lateral primary veins thinner, \pm alternately arranged, arising from central vein at $25-45^{\circ}$, at distances of $2-9 \mathrm{~mm}$ from lamina base, extending to upper third of lamina, main secondary veins in $\sim 4-7$ pairs at upper part of lamina, rather delicate, originating at $40-70^{\circ}$, initially straight, curved close to margin, forming well-developed loops, interior secondaries (between primary veins) closely arranged, mixed percurrent (opposite to alternate), almost perpendicular to primaries, minor secondaries (originating from lateral primaries outwards) arising at $30-50^{\circ}$, thin, course similar to main secondaries, tertiary veins weakly percurrent, higher-order veins forming a regular polygonal net.

Remarks. The affinity of these remains to $D$. polymorpha is obvious. This species is a dominant element in the flora of Kassanoi, with leaves typically broader and probably more leathery than those of Pitsidia and Metochia, suggesting either different ecological growth conditions or proximity to the depositional area. In the Greek Neogene, Daphnogene is quite common, with the exception of the Messinian floras of $\mathrm{N}$ Thessaly and $\mathrm{W}$ Macedonia. In Crete it has been documented in Makrilia (two specimens, as Cinnamomophyllum sp.) and Vrysses (two slender leaves) (Sachse, 2004; Zidianakis et al., 2007). Mantzouka et al. (2015) also described several leaves of this type from Metochia (as Daphnogene sp.). Pingen et al. (1994) described laurel fruit remains from the Miocene deposits of Kreuzau as Cinnamomum costatum (Mai) Pingen, Ferguson et Collinson, and proposed that these fruits and the foliage of $D$. polymorpha belong to the same natural species because both co-occur there.

\section{Genus Lindera Thunberg}

\section{?Lindera ovata Kolakovsky}

$$
\text { Pl. 7, figs 1-3 }
$$

?1957 Lindera ovata Kolakovsky, p. 277, pl. 14, figs 4, 5; pl. 15, fig. 1 (Kodor River, Abkhazia, Pliocene)

?2004 Dicotylophyllum type 3; Sachse, pl. 14, figs 11, 13, pl. 20, figs 39, 42 (Makrilia, E. Crete, Tortonian).

2015 ?Lindera ovata Kolakovsky; Mantzouka et al., figs 3.13-3.16 (Metochia, Gavdos Island, Tortonian).

Material. Pitsidia, two complete and two fragmentary leaves (Nrs 31.4.2.3956a,c; 31.4.2.3957a,b; 31.4.2.6925; 31.4.2.5806ai,bi). Metochia, two incomplete leaves (Nrs 31.5.2.12a,b; 31.5.2.16).

Description. Leaves petiolate, petiole fragmentary, $>7 \mathrm{~mm}$ long; lamina ovate to elliptic, possibly chartaceous, 35-52 mm long and $15-35 \mathrm{~mm}$ wide, L/W ratio $1.7-2.4$, base acute to obtuse, convex to cuneate, apex widely obtuse to rounded, rarely acute, margin entire; venation almost basal acrodromous, central primary vein moderately thick, \pm bent, lateral primary veins almost equal in thickness to central, suboppositely arranged, originating at $\sim 25-45^{\circ}$, running close to margin, sub-parallel, reaching upper quarter of lamina, main secondary veins in a few pairs, $\sim 3-5$, at upper part of lamina, delicate, originating at $35-50^{\circ}$, bent, looping along margin, interior secondaries dense, almost perpendicular to primaries, mixed percurrent (opposite to alternate), minor secondaries fine, 
markedly curved, forming loops at margin with adjacent ones, intersecondaries 1-3 per intercostal area, parallel, weak, higher-order veins forming a regular polygonal network.

Remarks. This material differs from $D$. polymorpha foliage mainly by the almost basal acrodromous venation and the wider apex. Quite similar leaves have been described by Kolakovsky (1957, 1964) from Kodor River. From Metochia, Mantzouka et al. (2015) assigned similar leaves to ?Lindera ovata as well, and, from Makrilia, Sachse (2004) referred several specimens to Dicotylophyllum type 3, which possibly matches our material.

?Lauraceae gen. et sp. indet. - folia Pl. 7, fig. 4

Material. Pitsidia, one complete leaf (Nr. 31.4.2.8115).

Description. Leaf shortly petiolate, petiole thick, $1.5 \mathrm{~mm}$ long, complete, lamina coriaceous, shape oblong, $27 \mathrm{~mm}$ long and $8 \mathrm{~mm}$ wide, $\mathrm{L} / \mathrm{W}$ ratio 3.4 , base almost cuneate, apex acute, margin entire, somewhat undulate; venation brochidodromous, primary vein strong, straight, secondary veins delicate, in $\sim 12$ pairs, originating at $50-75^{\circ}$, forming loops with adjacent ones near margin, intersecondaries present, 1-2 per intercostal area, parallel to secondaries, well developed, tertiary veins reticulate, forming a regular quadrangular to pentagonal network with higher-order venation.

Rem arks. Though small, this leaf resembles Lauraceae by its firm texture, entire margin and venation pattern.

\section{Monocotyledonae}

Family Arecaceae

Sub-family Coryphoideae

Genus Sabalites Saporta

\section{Sabalites sp.}

Pl. 6, fig. 1

?1999 Sabal major Heer; Velitzelos et al., fig. B in p. 461 (Vatera, Lesbos Island, Pliocene)

Material. Metochia, one incomplete leaf $(\mathrm{Nr}$. 31.5.2.44a,b).

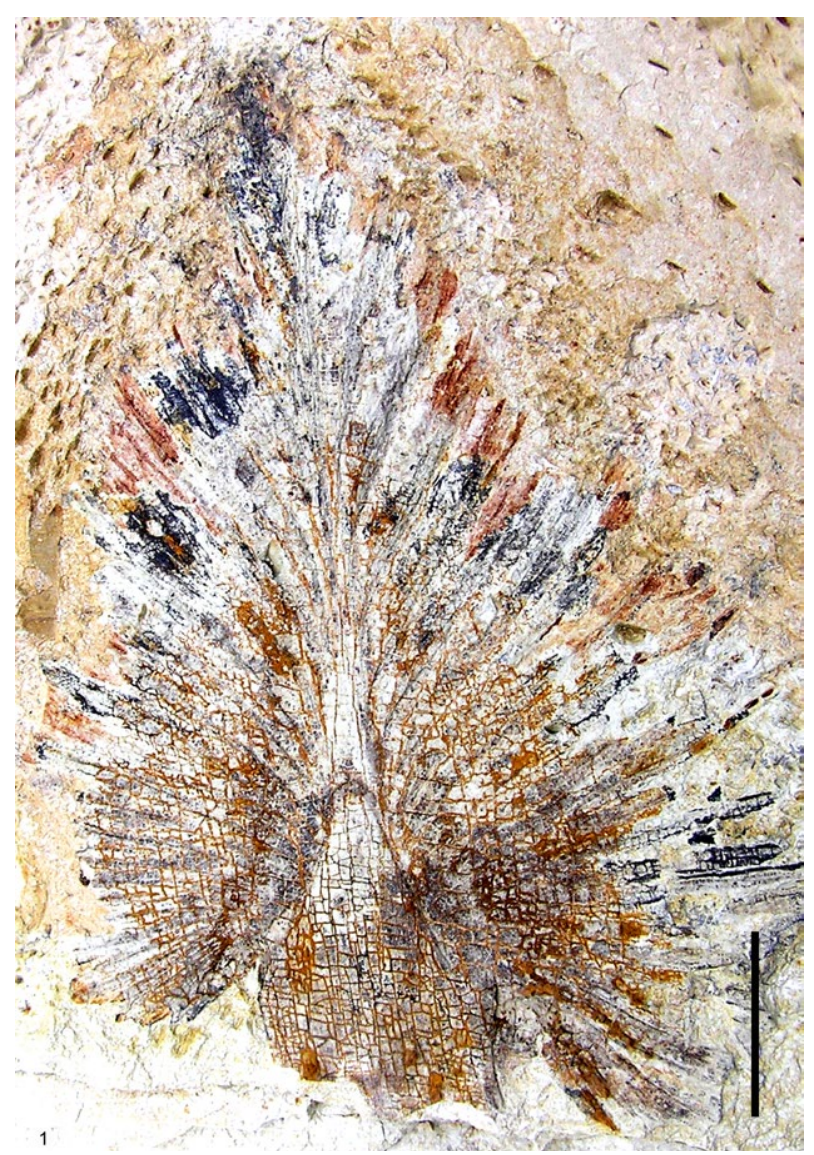

Plate 6. Palaeoflora of Metochia; 1. Sabalites sp., costapalmate leaf fragment, Nr. 31.5.2.44a. Scale bar $=2 \mathrm{~cm}$

Description. Leaf palmate, $13 \mathrm{~cm}$ long (incomplete) and $10 \mathrm{~cm}$ wide; petiole partly preserved, $1.4 \mathrm{~cm}$ long and $2.8 \mathrm{~cm}$ wide, robust, probably unarmed, extending into blade, forming a short costa $(2.5 \mathrm{~cm}$ long$)$ tapering rapidly towards apex; leaf segments $\sim 50$, emerging from costa in obtuse angles at basal part and in acute ones distally, fused, shape elongate, $\sim 5-8 \mathrm{~mm}$ wide in preserved part, wedge-shaped in transverse section; venation of segments parallelodromous, hardly visible.

Remarks. The costapalmate shape, along with the wedge-shaped segments, suggests an affinity to the tribes Corypheae or Borasseae of subfamily Coryphoideae (Dransfield et al., 2008). The relation of this specimen to Sabal is uncertain. Therefore, the fossil genus Sabalites, as introduced by Saporta (1865) and emended by Read and Hickey (1972), is considered more suitable. From the Miocene of Crete, the presence of fan palms has been recently reported from Makrilia (Velitzelos D. et al., 2014). 


\section{Family Altingiaceae}

\section{Genus Liquidambar L.}

\section{Liquidambar europaea}

\section{A. Braun (in Buckland)}

Pl. 7, figs 5-12; Pl. 8, figs 1-14; Pl. 9, figs 1-12; Fig. 13

1836 Liquidambar europaeum A. Braun (in Buckland), p. 513 (Öhningen, Germany, middle Miocene).

1954 Liquidambar europaea A. Braun; Hantke, p. 63 , pl. 8, figs 3-5, ?6; pl. 9, fig. 1 (Schrotzburg, Germany, Middle Miocene).

Folia:

1993 Liquidambar europaea A. Braun; Velitzelos, pl. 2, fig. 1 (Nea Stira, Euboea, early Miocene).

1994a Liquidambar europaeum A. Braun; Kleinhölter, pl. 21, figs 1-4 (Pyrgos and Zacharo basins, Peloponnese, Messinian).

1994b Liquidambar europaeum A. Braun; Kleinhölter, pl. 3, fig. 1 (Patra, Rion and Corinth basins, Peloponnese, Pliocene).

1995 Liquidambar europaeum A. Braun; Kleinhölter, pl. 2, fig. 6 (Patra, Rion and Corinth basins, Peloponnese, Pliocene).

?2002b Liquidambar europaea A. Braun; Velitzelos et al., p. 184 (Archangelos, Rhodes Island, Pleistocene) (no figure).

2010 Liquidambar europaea A. Braun; Zidianakis et al., fig. 21 (Pitsidia, central Crete, Tortonian).

2014 Liquidambar europaea A. Braun; Velitzelos D. et al., pl. 33, figs 3, 4 (Archangelos, Rhodes Island, Pleistocene).

Fructification:

1994a Liquidambar europaeum A. Braun; Kleinhölter, pl. 21, fig. 5 (Pyrgos and Zacharo basins, Peloponnese, Messinian).

1994a Liquidambar europaeum A. Braun; Kleinhölter, pl. 21, figs 6, 7 (Patra, Rion and Corinth basins, Peloponnese, Pliocene).

?1994a Liquidambar europaeum A. Braun; Kleinhölter, p. 197 (Skoura, Peloponnese, Pliocene) (no figure)

?2002b Liquidambar europaea A. Braun; Velitzelos et al., p. 184 (Archangelos, Rhodes Island, Pleistocene) (no figure).

2007 Liquidambar europaea A. Braun; Mai, Velitzelos, pl. 5, figs 17-19 (Kallithea, Rhodes Island, Pliocene/Pleistocene boundary).

2010 Liquidambar sp.; Zidianakis et al., fig. 2n (Pitsidia, central Crete, Tortonian).

2014 Liquidambar europaea A. Braun; Velitzelos D. et al., pl. 33, fig. 5 (Archangelos, Rhodes Island, Pleistocene).

2014 Liquidambar europaea A. Braun; Velitzelos D. et al., pl. 31, fig. 4 (Skoura, Peloponnese, Pliocene).

?2014 Liquidambar europaea A. Braun; Velitzelos D. et al., p. 70 (Elassona, Thessaly, Messinian) (no figure).
Material. Pitsidia, 2 almost complete leaves and 23 fragmentary ones (Nrs 31.4.2.276; 31.4.2.848ai,bi; 31.4.2.1487i; 31.4.2.2827a-d; 31.4.2.3747; 31.4.2.4014aii,bii; 31.4.2.4123a,b; 31.4.2.4253a,b; 31.4.2.4769a,b; 31.4.2.5278; 31.4.2.5358bi,5359i; 31.4.2.5385ai-c; 31.4.2.5601a,b; 31.4.2.5796a,b; 31.4.2.5808a,b; 31.4.2.5908a,b; 31.4.2.6001; 31.4.2.6082ai; 31.4.2.6149aopii; 31.4.2.6507; 31.4.2.6541; 31.4.2.6962i; 31.4.2.6964i; 31.4.2.8260; 31.4.2.8272); 38 almost complete fruiting heads and 20 fragmentary ones (Nrs 31.4.2.278; 31.4.2.820,821; ?31.4.2.881a,b; 31.4.2.975; 31.4.2.1034a,b; 31.4.2.1052; 31.4.2.1223iii; 31.4.2.1305a,b; 31.4.2.1600; 31.4.2.1857; 31.4.2.1928i; 31.4.2.1997; 31.4.2.2023; 31.4.2.2034; 31.4.2.2155a,b; 31.4.2.2375a,b; 31.4.2.2512; 31.4.2.2540ai,b; 31.4.2.2868a,b; 31.4.2.3047ai,bi; 31.4.2.3085a,b; 31.4.2.3145a,b; 31.4.2.3203; 31.4.2.3500; 31.4.2.3858; 31.4.2.3997aopii; 31.4.2.3997b; 31.4.2.4028bviii; 31.4.2.4028ci; 31.4.2.4028cii; 31.4.2.4037; 31.4.2.4093iii; 31.4.2.4327i; 31.4.2.4573; 31.4.2.4665; 31.4.2.4692; 31.4.2.4761; 31.4.2.4860; 31.4.2.4877,4865aii; 31.4.2.5096; 31.4.2.5181i; 31.4.2.5256; 31.4.2.5430aiv,bi; 31.4.2.5610; 31.4.2.5719; 31.4.2.5798; 31.4.2.5935ai,bi; 31.4.2.6026bi; 31.4.2.6039,6026bi; 31.4.2.6184a, b; 31.4.2.6209; 31.4.2.6809; 31.4.2.6813i; 31.4.2.6963aii,bi; 31.4.2.6980; 31.4.2.6982; 31.4.2.6989a,b; 31.4.2.8160).

Description. Leaves mostly fragmented, long petiolate, petiole rarely preserved, $>39 \mathrm{~mm}$ long; lamina palmate, three- or five-lobed, 27-50 mm long, 44-58 mm wide, $\mathrm{L} / \mathrm{W}$ ratio $0.63-0.85$, base mostly cordate, apex of lobes acute to acuminate, margin regularly crenulate, lobes oblong to lanceolate or triangular, central lobe broader than lateral ones, sinuses angular, acute to obtuse, teeth small, rounded or rarely acute, with glanduliferous apices; venation actinodromous, 3 or 5 primary veins, depending on number of lobes, in five-lobed leaves the lateral-most primary veins often originating supra-basally, central primary vein stout, straight or bent, lateral primary veins thinner, curved, rarely straight, arising at $50-95^{\circ}$ from midrib, secondary veins semicraspedodromous, mostly alternately arranged, curved, arising at rather acute angles, interconnected near margin, tertiary veins weakly percurrent (alternate), venation of higher orders forming an irregular network. 

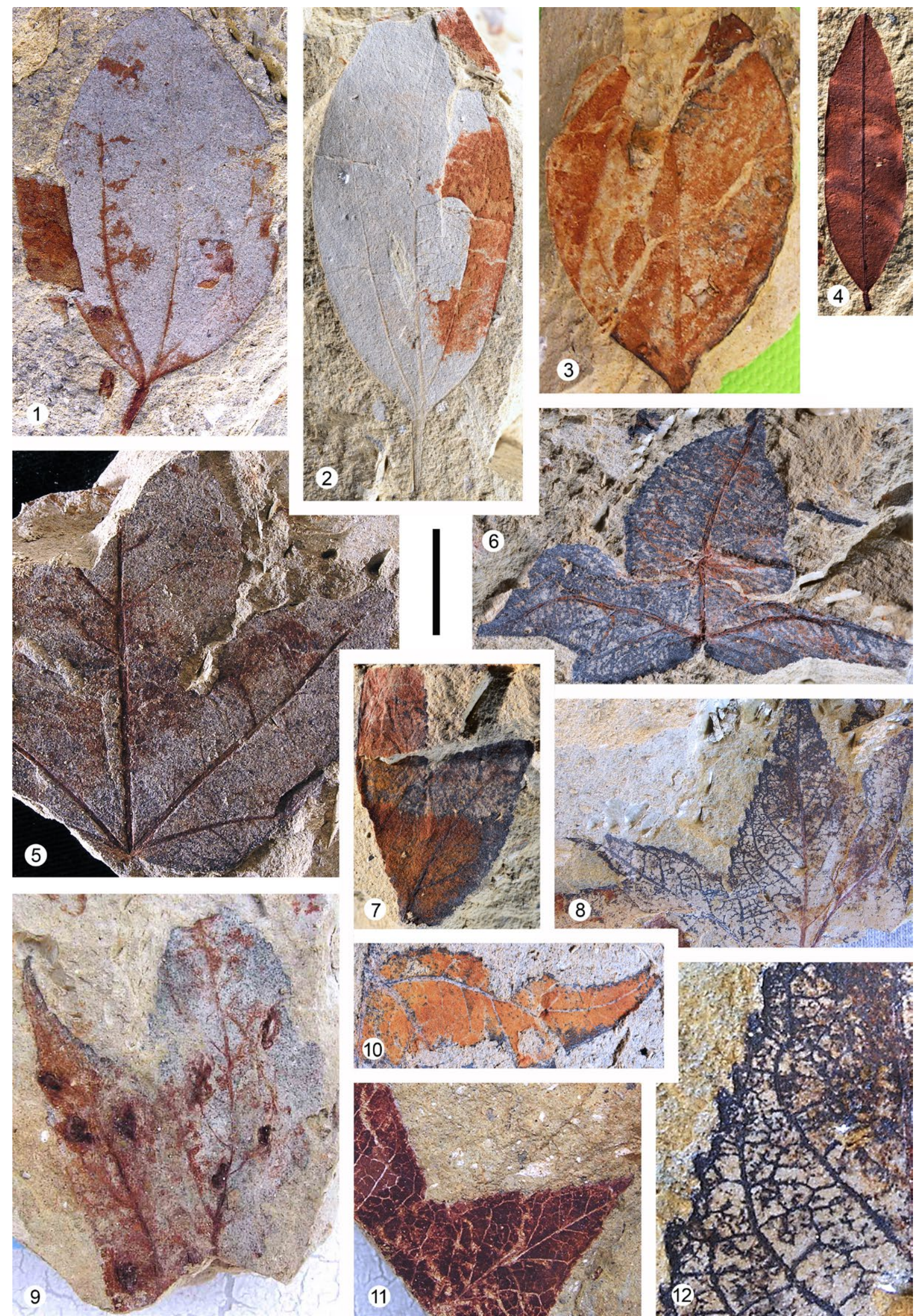

Plate 7. Cretan palaeofloras, scale bar $=1 \mathrm{~cm}$ (unless otherwise stated); 1-3. ?Lindera ovata Kolakovsky, foliage; 1. Pitsidia, Nr. 31.4.2.3957b; 2. Pitsidia, Nr. 31.4.2.6925; 3. Metochia, Nr. 31.5.2.12a; 4. ?Lauraceae gen. et sp. indet., foliage, Pitsidia, Nr. 31.4.2.8115; 5-12. Liquidambar europaea A. Braun, foliage, Pitsidia; 5. Nr. 31.4.2.5796a; 6. Nr. 31.4.2.6001; 7. Nr. 31.4.2.5808a; 8. well-preserved margin and venation details, Nr. 31.4.2.3747; 9. with prominent galls, Nr. 31.4.2.276; 10. leaf lobe, Nr. 31.4.2.6962i; 11. leaf fragment, Nr. 31.4.2.8260; 12. close-up, showing marginal teeth and venation pattern, Nr. 31.4.2.3747 detail, scale bar $=3 \mathrm{~mm}$ 

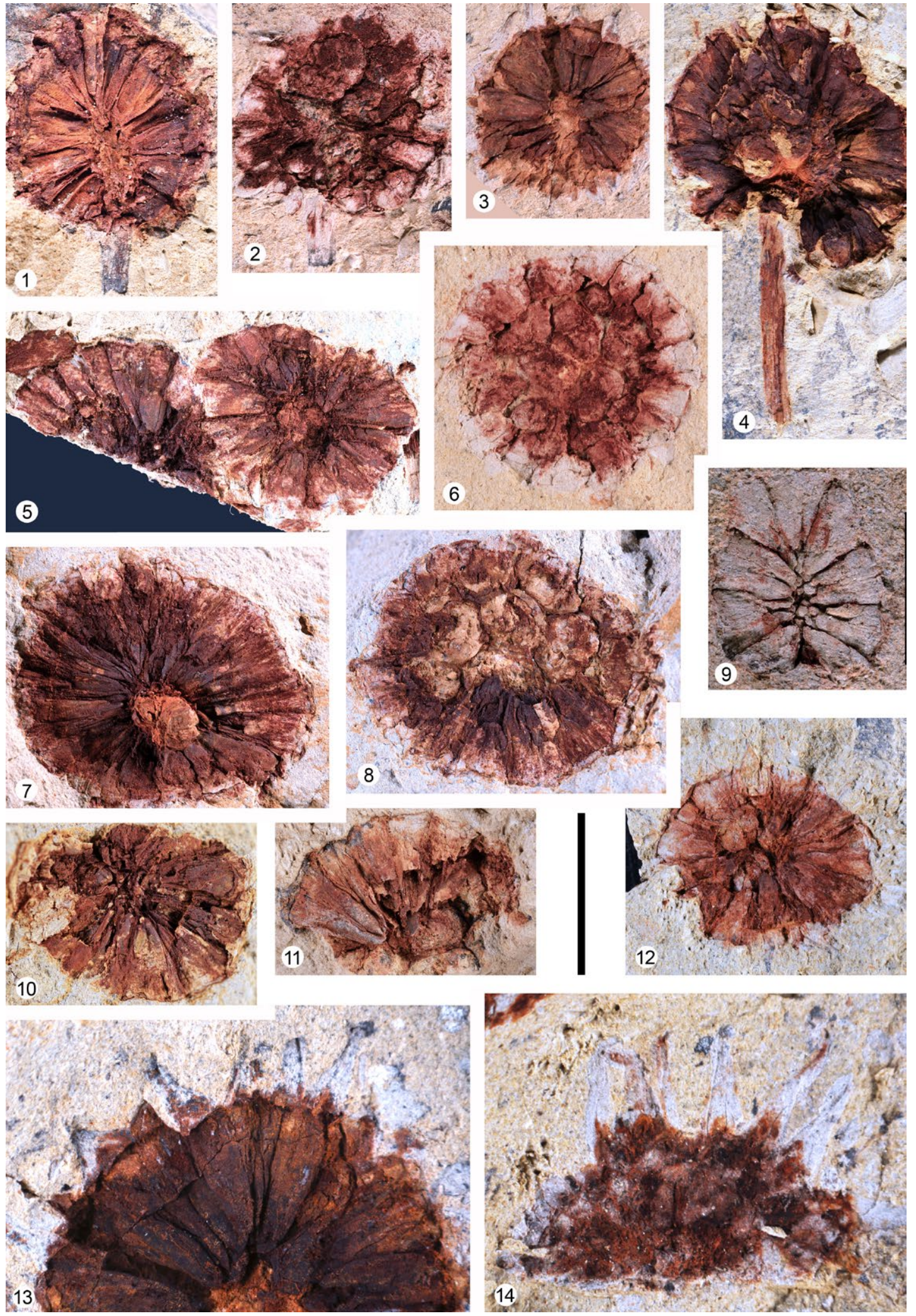

Plate 8. Palaeoflora of Pitsidia, scale bar $=1 \mathrm{~cm}$ (unless otherwise stated); 1-14. Liquidambar europaea A. Braun, fruiting heads; 1. note densely arranged bilocular capsules, Nr. 31.4.2.820; 2. Nr. 31.4.2.2868a; 3. numerous styles crowning the fructification, Nr. 31.4.2.6184a; 4. with long peduncle, Nr. 31.4.2.3500; 5. two fruiting heads closely arranged, Nr. 31.4.2.4028c; 6. Nr. 31.4.2.2375b; 7. central axis well-preserved, Nr. 31.4.2.2155a; 8. note honeycomb-like structure, Nr. 31.4.2.2155b; 9. impression, preserved in coarser sediment, Nr. 31.4.2.1034b; 10. Nr. 31.4.2.3047bi; 11. fragmentary head with well-preserved capsules, Nr. 31.4.2.5610; 12. complete styles crowning the fructification, Nr. 31.4.2.5798; 13. broken styles, close-up, Nr. 31.4.2.6184a detail, scale bar $=4 \mathrm{~mm}$; 14. complete styles, Nr. 31.4.2.5935bi, scale bar $=4 \mathrm{~mm}$ 

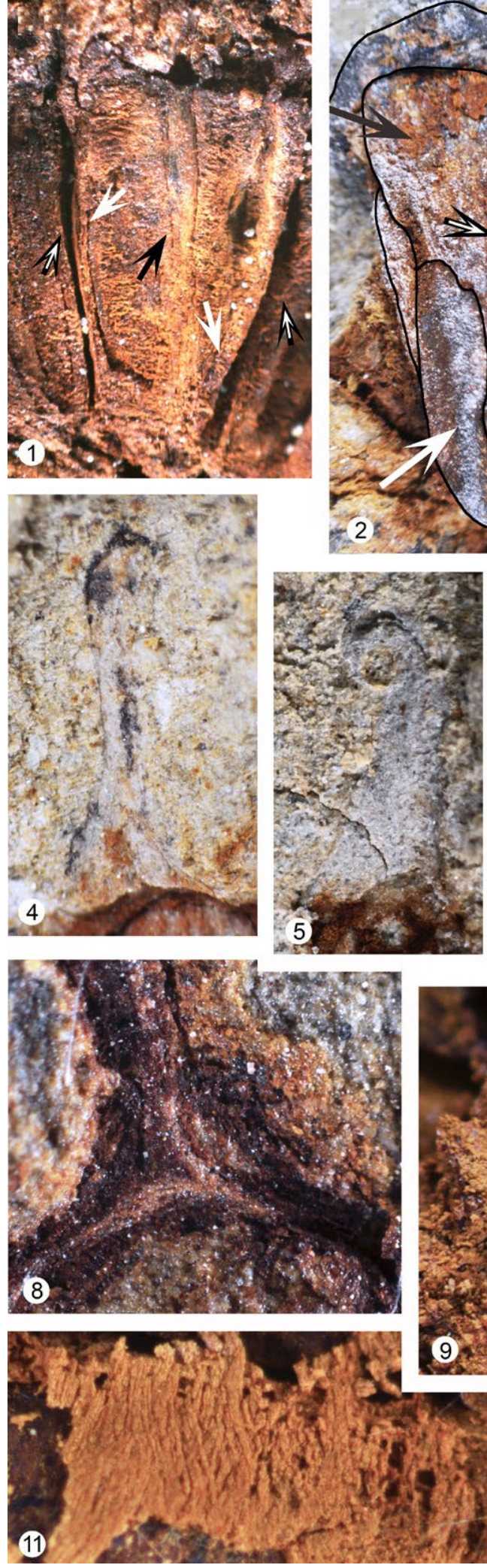
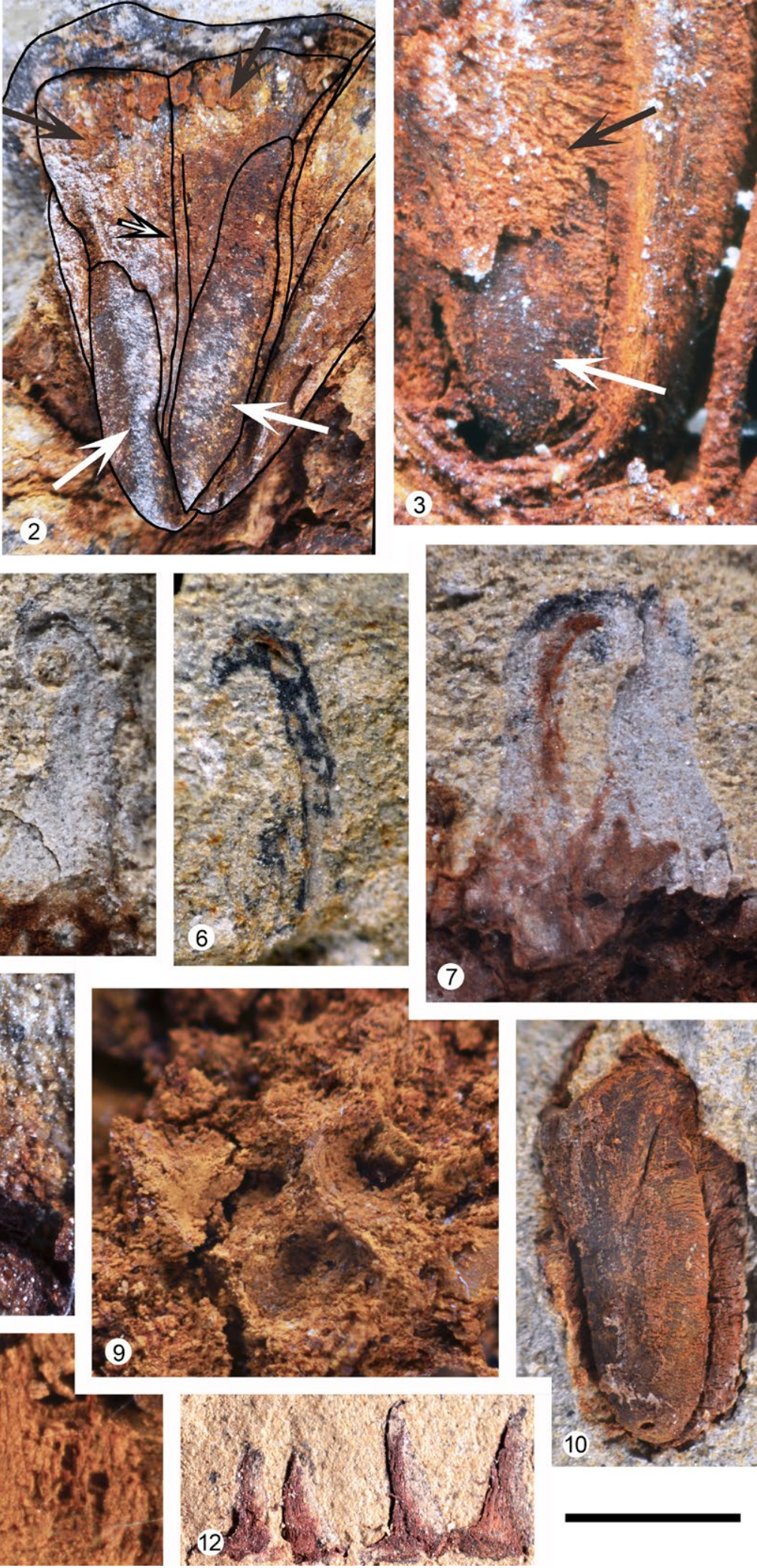

Plate 9. Palaeoflora of Pitsidia, scale bar = $1.5 \mathrm{~mm}$ (unless otherwise stated); 1-12 Liquidambar europaea A. Braun, details of fruiting heads; 1. capsule with two carpels, carpel fusion (ventral seem) (black arrow), dorsal seems (white arrows), gap between capsules (black-white arrow), Nr. 31.4.2.820 detail, scale bar $=2 \mathrm{~mm}$; 2. capsule, the two carpels (black arrows), ventral seam (black-white arrow), locules (white arrows) are lined, Nr. 31.4.2.5610 detail, scale bar $2.5 \mathrm{~mm}$; 3. basal part of carpel, note carpel wall characterised with fine transverse ridges (black arrow) and the seed (white arrow), Nr. 31.4.2.820 detail, scale bar = $1 \mathrm{~mm}$; 4. persistent style, Nr. 31.4.2.5798 detail; 5. persistent style, Nr. 31.4.2.5935bi; 6. persistent style, Nr. 31.4.2.5798 detail; 7. two adjacent persistent styles, Nr. 31.4.2.5935ai detail; 8. smooth, slightly thickened area between capsules (peripheral rim), close-up, Nr. 31.4.2.278 detail, scale bar $=1 \mathrm{~mm} ; \mathbf{9}$. scars of capsule bases on central axis of infructescence, Nr. 31.4.2.4573 detail, scale bar $=2 \mathrm{~mm}$; 10. isolated capsule detected in sediment, Nr. 31.4.2.6209, scale bar $=3 \mathrm{~mm} ; \mathbf{1 1}$. fine transverse ridges of carpel wall, close-up, Nr. 31.4.2.4573 detail, scale bar $=0.5 \mathrm{~mm} ; \mathbf{1 2}$. isolated styles detected in sediment, Nr. 31.4.2.881a, scale bar $=4 \mathrm{~mm}$ 


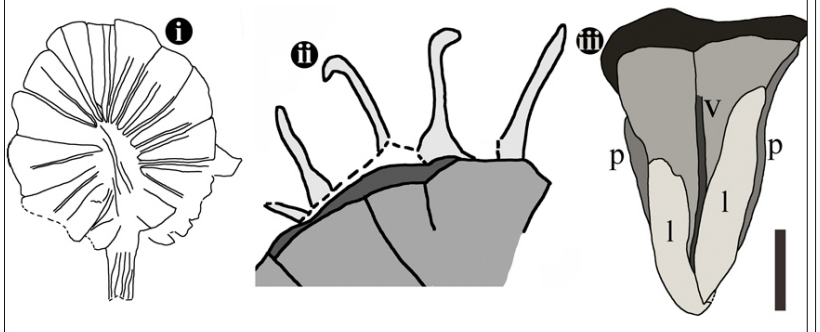

a

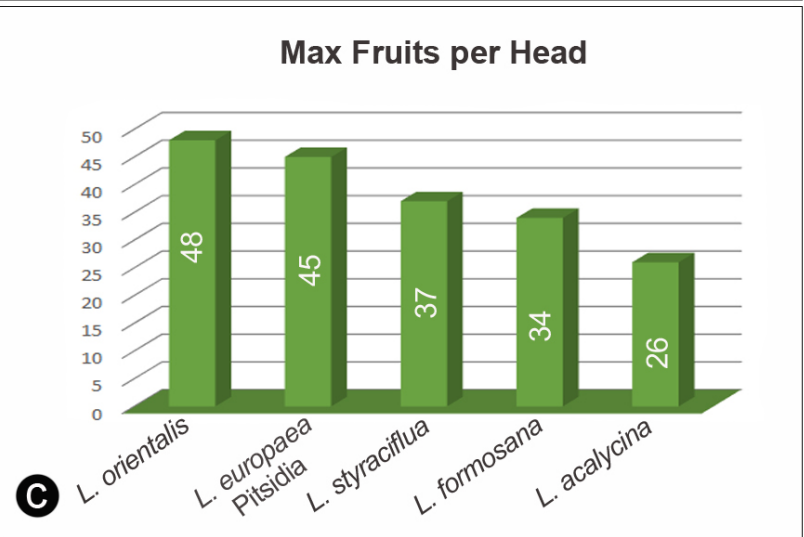

Fruiting Head Diameter

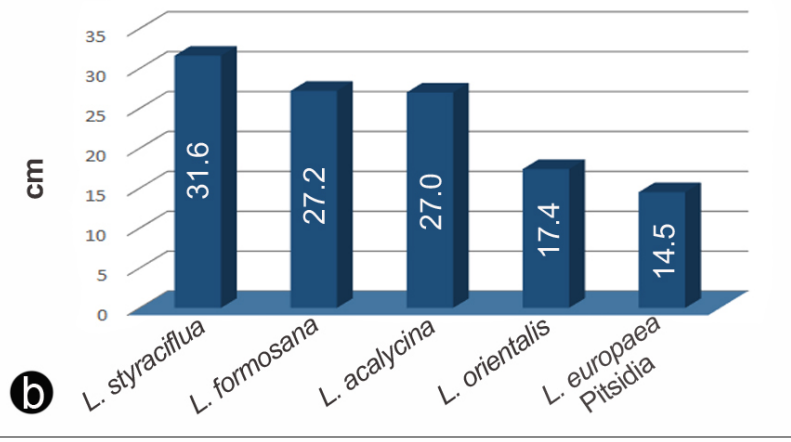

Length of Style Remnants

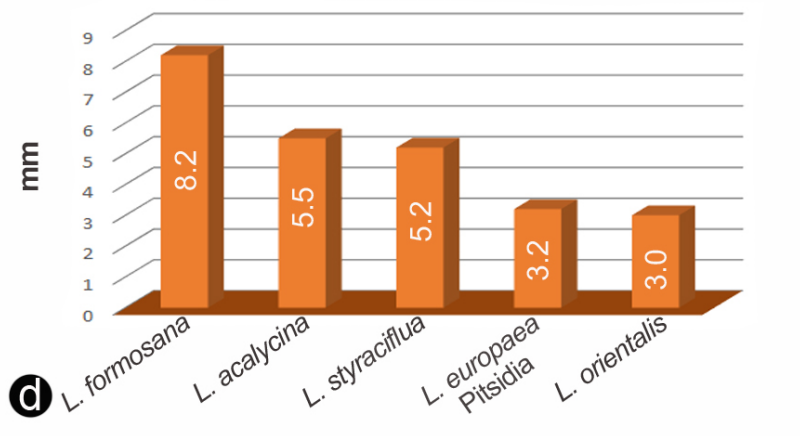

Fig. 13. Palaeoflora of Pitsidia. Liquidambar europaea; a. i-iii. fructification line drawings; i. fruiting head, Nr. 31.4.2.820, scale bar $=5 \mathrm{~mm}$; ii. pesistent styles of fruiting head with curved tips and triangular-shaped bases, Nr. 31.4.2.5798 detail, scale bar = $2 \mathrm{~mm}$; iii. capsule with two carpels (s. ventral seem, l. locules, p. pericarp), Nr. 31.4.2.5610 detail, scale bar $=2 \mathrm{~mm}$; b-d. biometric fructification comparisons with the extant species of Liquidambar; b. diameter of fruiting head; c. maximum fruits per head; $d$. length of style remnants; data for modern species are from Ickert-Bond et al. (2005)

Fructifications. Imprints with well-developed inorganic structures of solitary, probably woody, capitate infructescences (fruiting heads), pedunculate, composed of dense clusters of fruits; peduncles in most cases missing or fragmentarily preserved, $>12 \mathrm{~mm}$ long and $\sim 1.5 \mathrm{~mm}$ wide, extending into inner part of infructescence, as central axis; shape of fruiting head lenticular as a result of compression, original shape probably spherical or almost spherical, 8-21 mm (average $14.5 \mathrm{~mm}$ ) in diameter, $\mathrm{L} / \mathrm{W}$ ratio $1-1.1$, with $30-45$ fruits; fruits elongate, \pm wedge-shaped, bilocular capsules, 4.5-8 mm long, $2.5-4.5 \mathrm{~mm}$ wide, arranged fairly tightly on central axis, inner pericarp wall thin with fine transverse ridges on surface, locules elongate, cone- to sack-like; along outer surface of infructescence the adjacent fruits form roundish pentagons or hexagons (honeycomb-like structures), area between fruits peripheral rim sensu Gregor (1978) and Ferguson (1989) - smooth, somewhat thickened, with a fine fusion line; style remains occasionally preserved, narrow elongate, straight, slightly bent or S-like, with triangular-shaped bases and curved to hook-like tips, $2.5-4.0 \mathrm{~mm}$ (average $3.2 \mathrm{~mm}$ ) long and 1-2 mm wide at base, no other extrafloral structures such as spines or knobs detected.

Remarks. Unlike the foliage, the fruiting heads are quite abundant and well-preserved in Pitsidia. Several members of the Altingiaceae bear their fruits in a capitulum (head) at the end of a long peduncle. Specific features such as the capsule shape and the occurrence of persistent styles allowed an assignment to Liquidambar sensu stricto (Bolge, 1986; Ferguson, 1989; Ickert-Bond et al., 2005; Ickert-Bond and Wen 2006, 2013). According to Gregor (1978) and Mai (1997, 1999), most of the infructescences described from Europe as L. magniloculata Czeczott et Skirgiello, L. pliocenica Geylard et Kinkelin or L. orientalis fossilis constitute in fact L. europaea, which is considered the valid name for all of them. In many cases, however, fruiting heads are not well preserved, consisting of compressions without diagnostic features (Ferguson, 1989). L. wutzleri Gregor differs from $L$. europaea by 
the wart- to thorn-like radial extensions on the surface polygonals between the capsules (Gregor, 1993). Such structures are lacking in the examined material from Pitsidia.

Most palaeobotanists have classifed L. europaea to the modern section Liquidambar. Based on head macro- and micromorphological characters, some authors related it to modern $L$. orientalis (Mai, 1997, 1999) (contrary to the results from leaf morphology, which suggest a closer relationship to $L$. styraciflua), while earlier it was placed between $L$. orientalis and L. styraciflua (Unger, 1847; Heer, 1856; Gregor, 1978). The morphology and biometrics of the material from Pitsidia, such as size of heads and carpels, number of capsules per head, morphology and length of persistent styles, smooth thickened areas between adjacent fruits and the lack of other extrafloral structures, support a closer relation to the modern species L. orientalis (Fig. $13 \mathrm{~b}-\mathrm{d}$ ). So far, this element is absent from the palaeofloras of Vrysses, Kassanoi and Metochia. A single infructescence has been reported from Makrilia (Zidianakis, 2018: Pl. 52, fig. 7), whereas leaf remains are entirely lacking there.

\section{Family Fabaceae}

Genus Leguminosites

Bowerbank emend. Schimper

\section{Leguminosites $\mathrm{sp} .1$}

Pl. 10, fig. 1

M a t e r i a l. Pitsidia, one almost complete leaflet (Nr. 31.4.2.5295a,b).

Description. Probably a leaflet, petiolule missing, shape oblong to broad elliptic, $42 \mathrm{~mm}$ long, $19 \mathrm{~mm}$ wide, L/W ratio 2.3 , base obtuse, rounded but acute at the very base, somewhat asymmetric, apex retuse, margin entire; venation brochidodromous, primary vein strong, straight, secondary veins much more delicate, in $\sim 10$ pairs originating at $35-75^{\circ}$, almost straight, looping at different distances from margin, intersecondaries numerous, parallel, indistinct, higher-order venation hardly preserved.

Re m a r ks. The retuse apex, the slightly asymmetric base, the entire margin and the brochidodromous venation pattern, with several intersecondaries, are features that often occur in the family Fabaceae. From Makrilia, Sachse (2004) reported diverse leaflets of Fabaceae affinity. He classified most of them in eight different taxa. Some of them and especially ?Swartzia sp. show similarities to the specimen from Pitsidia. Although several specimens of leguminosoid leaflets are available from Vrysses, none closely resembles the leaflet at hand. Mantzouka et al. (2015) described four taxa of Fabaceae from Metochia. Judging from the descriptions and figures, Leguminosites sp. 2 resembles the here-described leaflet.

\section{Leguminosites sp. 2}

Pl. 10, fig. 2

2010 Leguminosae gen. indet., Zidianakis et al., fig. 3j (Pitsidia, central Crete, Tortonian).

Material. Pitsidia, one complete leaflet (Nr. 31.4.2.207).

Description. Leaflet shortly petiolulate, petiolule $5 \mathrm{~mm}$ long, texture coriaceous, shape slightly obovate, $51 \mathrm{~mm}$ long, $23 \mathrm{~mm}$ wide, $\mathrm{L} / \mathrm{W}$ ratio 2.1 , base cuneate at one side, convex at the other, asymmetric, apex obtuse, retuse, margin entire to slightly crenate apically; venation brochidodromous, midrib prominent, straight, abruptly bent at base, secondary veins $\sim 12$ pairs, delicate, originating at $45-75^{\circ}$, irregularly spaced, occasionally dichotomising close to primary vein, straight, gently curved distally, interconnected in loops with adjacent secondaries or intersecondaries along margin, intersecondary veins mostly one or even two per intercostal area, well developed, quite similar to secondaries, tertiary veins conspicuous, anastomosing with higher-order venation and forming an irregular net.

Remarks. This well-preserved specimen shares only a few features with Leguminosites sp. 1, such as apex shape and brochidodromous venation pattern. They are therefore treated as different taxa.

\section{?Leguminosites sp. 3}

Pl. 10, fig. 3

Material. Metochia, one complete and one fragmentary leaflet (Nrs 31.5.2.49; 31.5.2.51).

Description. Leaflets petiolulate, petiolule partly preserved, $1.5 \mathrm{~mm}$ long; texture coriaceous, shape narrow oblong, $\sim 35 \mathrm{~mm}$ long and 9-12 $\mathrm{mm}$ wide, L/W ratio almost 3 , base convex but concave near the very base, strongly asymmetric (basal insertion asymmetry), apex 


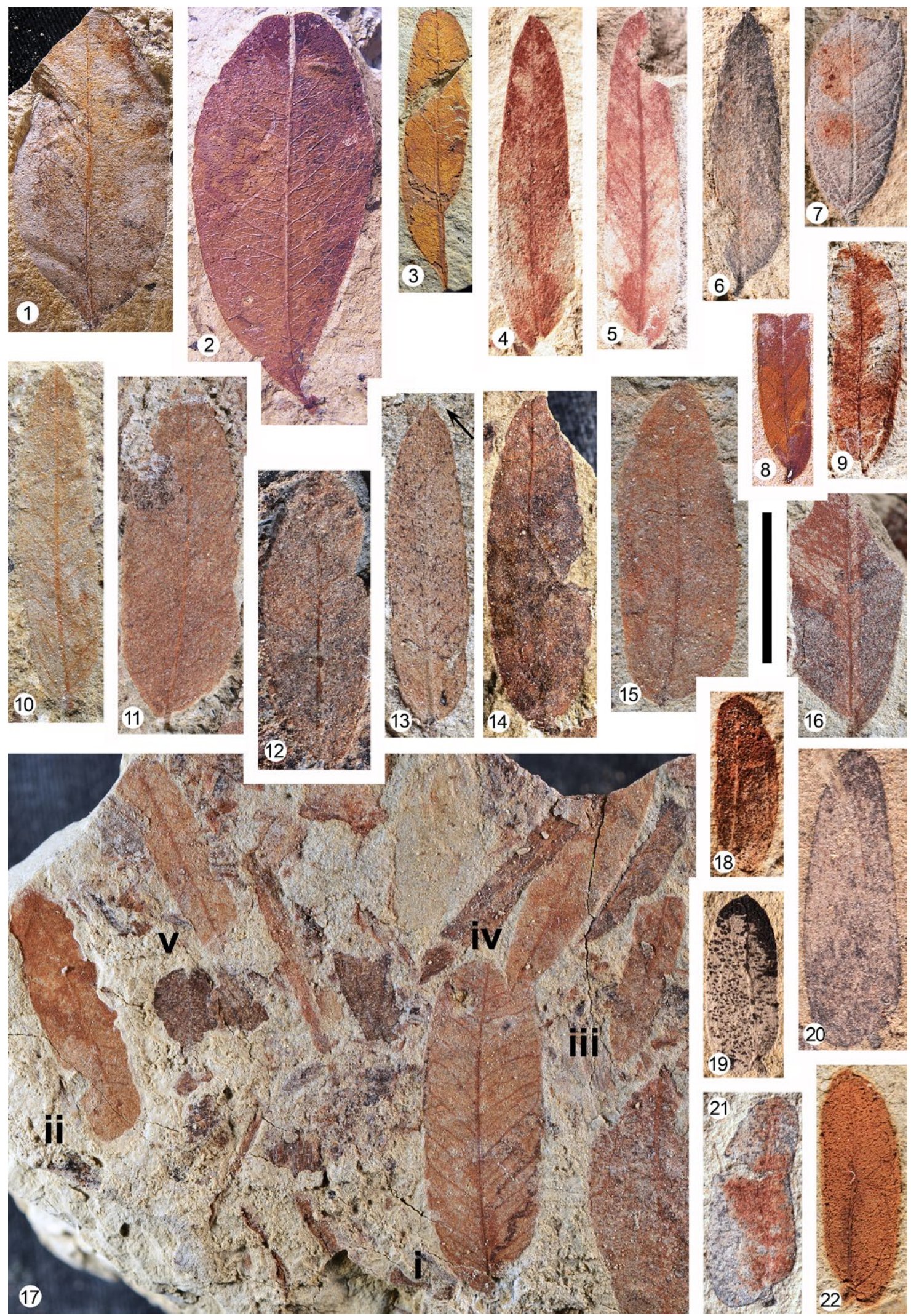

Plate 10. Cretan palaeofloras; 1-3. Leguminosites Bowerbank emend. Schimper, leaflets, scale bar $=2 \mathrm{~cm} ; 1$. Leguminosites sp. 1, Pitsidia, Nr. 31.4.2.5295a; 2. Leguminosites sp. 2, Pisidia, Nr. 31.4.2.207 (Fig. 3j in Zidianakis et al., 2010); 3. ?Leguminosites sp. 3, Metochia, Nr. 31.5.2.49; 4-17. Podocarpium podocarpum (A. Braun) Herendeen, leaflets, scale bar $=1 \mathrm{~cm} ; 4$. Pitsidia, Nr. 31.4.2.3801a; 5. Pitsidia, (counterpart of Pl. 10, fig. 4), Nr. 31.4.2.3801b; 6. Pitsidia, Nr. 31.4.2.5552i; 7. Pitsidia, Nr. 31.4.2.8244iii; 8. Pitsidia, Nr. 31.4.2.2705aii; 9. Pitsidia, Nr. 31.4.2.5215opi; 10. Kassanoi, Nr. 31.6.2.228; 11. Kassanoi, Nr. 31.6.2.15v; 12. Kassanoi, Nr. 31.6.2.180i; 13. note acuminate apex (arrow), Kassanoi, Nr. 31.6.2.205; 14. Kassanoi, Nr. 31.6.2.218; 15. Kassanoi, Nr. 31.6.2.169; 16. Kassanoi, Nr. 31.6.2.66aop; 17. slab with five leaflets closely arranged, Kassanoi, Nr. 31.6.2.168; 18-22. Mimosites sp., leaflets, Pitsidia, scale bar = 5 mm; 18. Nr. 31.4.2.2371; 19. Nr. 31.4.2.4398ai; 20. Nr. 31.4.2.5324; 21. Nr. 31.4.2.4087bi; 22. Nr. 31.4.2.4389aii 
rounded, slightly mucronate, margin entire; venation brochidodromous, primary vein strong, straight, tapering along length, secondary veins $\sim 10-14$ pairs, distinctly weaker than midvein, diverging from midrib at $40-75^{\circ}$, straight or smoothly bent upwards, near apex slightly recurved, joining in arcs the adjacent secondaries and intersecondaries at some distance from margin, intersecondary veins 1 or rarely 2 per intercostal area, well developed, parallel to secondaries, tertiary veins reticulate, anastomosing at various angles and forming an irregular network.

Rem arks. The strongly asymmetric base, the entire margin, apex shape and venation architecture point towards the legume family. The studied specimens do not match any of the leaf morphotypes within Fabaceae described by Mantzouka et al. (2015).

\section{Subfamily Caesalpinioideae}

\section{Genus Podocarpium}

A. Braun ex Stizenberger

\section{Podocarpium podocarpum}

(A. Braun) Herendeen

Pl. 10, figs 4-17; Pl. 11, figs 1-11; Fig. 14

1845 Gleditschia podocarpa A. Braun, p. 173 (Öhningen, Germany, middle Miocene)

1859 Podogonium knorrii (Braun) Heer, Heer pl. 134, figs 22-26a; pl. 135, figs 1-18, 20-26; pl. 136, figs 1-9 (Öhningen, Germany, middle Miocene)

1992a Podocarpium podocarpum (A. Braun); Herendeen, p. 732 (European Tertiary)

1880 Podocarpium lyellianum Heer; Stur in Teller, (Kap Nenita, Chios Island, Serravallian-Tortonian)

2004 Podocarpium podocarpum (A. Braun) Herendeen; Sachse, pl. 12, fig. 16 (Makrilia, E. Crete, Tortonian)

2010 Podocarpium podocarpum (A. Braun) Herendeen; Zidianakis et al., fig. 3e (Pitsidia, central Crete, Tortonian)

2014 Podocarpium podocarpum (A. Braun) Herendeen; Velitzelos D. et al., pl. 25, figs 3-5 (Kato Komi, Chios Island, Serravallian-Tortonian)

Material. Pitsidia, 7 complete or almost complete leaflets and 6 fragmentary ones

(Nrs 31.4.2.2705aii; 31.4.2.2720i;

31.4.2.3801a,b; 31.4.2.3933; 31.4.2.4016;

31.4.2.4183a,b; 31.4.2.4543ai,bi;

31.4.2.5215opi; 31.4.2.5552i; 31.4.2.5629a,b;

31.4.2.6297,6294op; 31.4.2.8180op;

31.4.2.8244iii); 12 complete or almost complete fruits and 8 fragmentary ones (Nrs 31.4.2.2704a,b; 31.4.2.3597a,b; 31.4.2.3727aopi; 31.4.2.3968a,b; 31.4.2.4134; 31.4.2.4284aii,b; 31.4.2.4396; 31.4.2.4495a,b; 31.4.2.4672;

31.4.2.4706a,b; 31.4.2.4833i; 31.4.2.5600ai,b; 31.4.2.5827; 31.4.2.5884ai,bi; 31.4.2.6166bopi; 31.4.2.6478ai,bi; 31.4.2.6575a,b; 31.4.2.6662a,b; 31.4.2.6931a,b; 31.4.2.8262iii).

Kassanoi, 26 complete or almost complete leaflets and 9 fragmentary ones

(Nrs 31.6.2.15iii; 31.6.2.15v; 31.6.2.24ii;

31.6.2.26ii; 31.6.2.30ii; 31.6.2.35iii; 31.6.2.37ii; 31.6.2.66aop; ?31.6.2.91ii; 31.6.2.100iii; 31.6.2.119ix; 31.6.2.119xii; 31.6.2.152ii;

31.6.2.166aii; 31.6.2.168ai,bi; 31.6.2.168aii,bii; 31.6.2.168aiii,biii; 31.6.2.168aiv,biv;

31.6.2.168av,bv; 31.6.2.169; 31.6.2.177i;

31.6.2.178; 31.6.2.180i; 31.6.2.182i; 31.6.2.185; 31.6.2.187; 31.6.2.188; 31.6.2.196i; 31.6.2.205; 31.6.2.206; ?31.6.2.210; 31.6.2.214; 31.6.2.216; 31.6.2.218; 31.6.2.228).

Description. Leaflets sessile or shortly petiolulate $(\sim 0.5 \mathrm{~mm}$ long), lamina narrow elliptic to lanceolate, $\sim 7-24 \mathrm{~mm}$ long and $2-8 \mathrm{~mm}$ wide, $\mathrm{L} / \mathrm{W}$ ratio $2.0-4.8$, base obtuse to acute, convex, occasionally cuneate, asymmetric, apex acute to obtuse or rounded, emarginate, seldom mucronate, margin entire; venation brochidodromous with characteristic pair of prominent asymmetric basal secondary veins originating at acute angles and running parallel to leaf margin; midrib strong, straight, secondary veins numerous, much weaker than midrib, arranged 0.5$1.5 \mathrm{~mm}$ apart, arising at acute angles and forming angular loops near margin, intersecondary veins present, simple, parallel to secondaries, weakly developed, tertiaries forming a dense, irregular, polygonal network.

Fruits. Long-stipitate one-seeded pods consisting of two valves, dehiscent along both sutures; stipe straight or slightly bent, $25-38 \mathrm{~mm}$ (average $31.5 \mathrm{~mm}$ ) long and $\sim 1 \mathrm{~mm}$ wide, slightly swollen at base; valves elliptic, 21-29 mm (average 24.6) long and 7-11 mm (average $9 \mathrm{~mm}$ ) wide, base acute, slightly oblique, apex acute, rounded or frequently with \pm developed projection (style remnant), margin entire, occasionally showing rather fine marginal line running parallel to valve edge, visible from inner side, distance of valve edge to marginal line $0.1-0.2 \mathrm{~mm}$, possibly representing the width of the suture, venation indistinct, oblique, with numerous anastomoses, forming a polygonal network; seeds not 

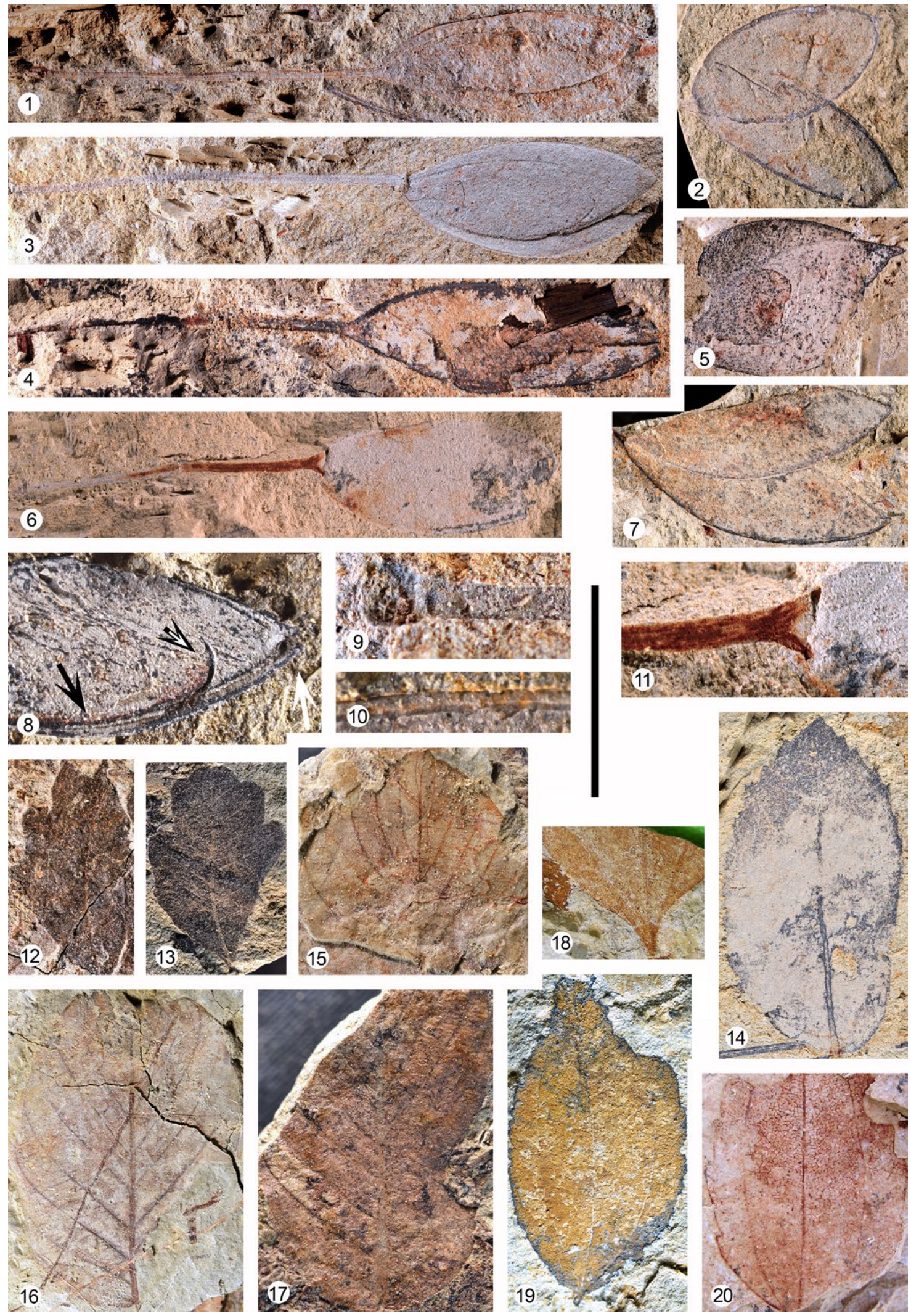

Plate 11. Cretan palaeofloras, scale bar $=2 \mathrm{~cm}$ (unless otherwise stated); 1-11. Podocarpium podocarpum (A. Braun) Herendeen, fruits (pods), Pitsidia; 1. Nr. 31.4.2. 6478ai; 2. Nr. 31.4.2.5884ai; 3. Nr. 31.4.2.3968a; 4. Nr. 31.4.2.4495a; 5. Nr. 31.4.2.3597a; 6. Nr. 31.4.2.4833i; 7. Nr. 31.4.2.5600b; 8. note suture (black arrow), style remnant (white arrow), funiculus (black-white arrow), valve close-up, Nr. 31.4.2.6662a detail, scale bar = $1 \mathrm{~cm} ; \mathbf{9}$. swollen base of stipe, Nr. 31.4.2.3968a detail, scale bar $=4 \mathrm{~mm} ; \mathbf{1 0}$. double-seamed margin of valve, $\mathrm{Nr}$ 31.4.2.4706a detail, scale bar $=2 \mathrm{~mm}$; 11. mechanical damage at stipe-valve connection, $\mathrm{Nr}$. 31.4.2.4833i detail, scale bar $=6 \mathrm{~mm} ; \mathbf{1 2}$, 13. Rosaceae gen. et sp. indet. type 2, foliage, Kassanoi; 12. Nr. 31.6.2.119vi; 13. Nr. 31.6.2.18ai; 14. Rosaceae gen. et sp. indet. type 1, lateral leaflet, Pitsidia, Nr. 31.4.2.6166a; 15-17. Berchemia multinervis (A. Braun) Heer, foliage, Kassanoi; 15. apical part, Nr. 31.6.2.163; 16. Nr. 31.6.2.158ii; 17. Nr. 31.6.2.170iii; 18-20. Ziziphus paradisiaca (Unger) Heer, foliage. Metochia; 18. basal part, Nr. 31.5.2.15; 19. Nr. 31.5.2.57; 20. Nr. 31.5.2.13ai 


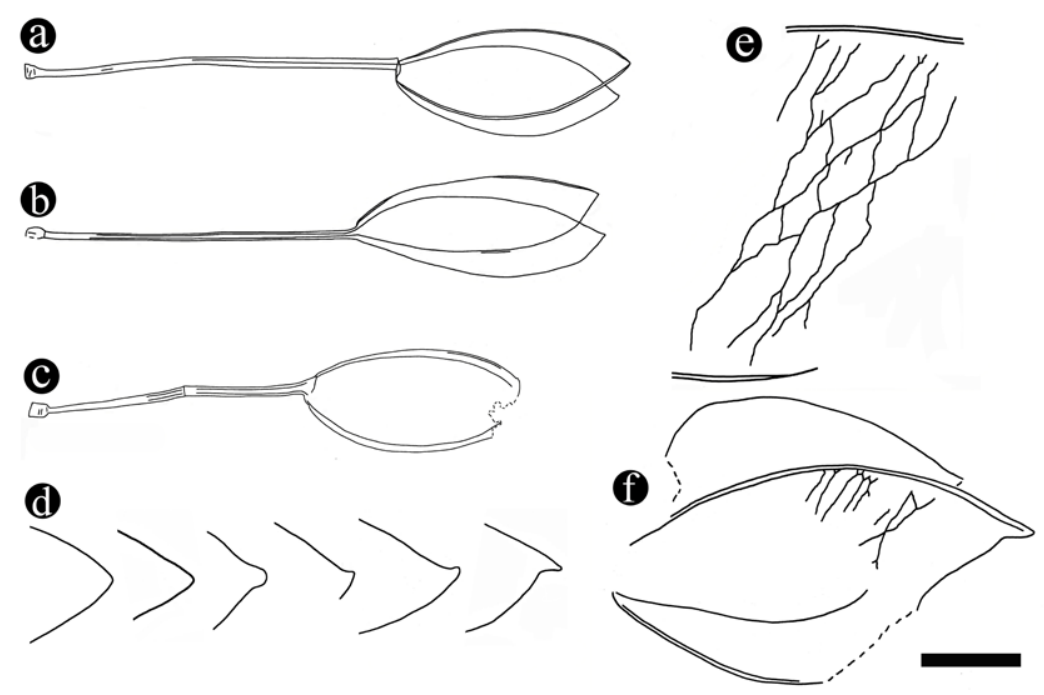

Fig. 14. Palaeoflora of Pitsidia. Podocarpium podocarpum fruits (pods), line drawings, scale bar $=1 \mathrm{~cm}$ (unless otherwise stated); a. Nr. 31.4.2.3968a; b. Nr. 31.4.2. 6478ai; c. Nr. 31.4.2.4833i; d. shape of valve apices, scale bar = 5 mm; e. venation on valve surface, Nr. 31.4.2.3597a detail, scale bar $=3 \mathrm{~mm}$; f. Nr. 31.4.2.3597a, scale bar $=5 \mathrm{~mm}$

preserved; funiculus discernable in a few specimens, slender, 2-3 mm long, curved, situated in apical third of placental suture, indicating seed attachment at apical part of pod.

Remarks. The features of both leaflets (especially the asymmetric base and the presence of a prominent basal pair of secondaries) and fruits match $P$. podocarpum very well. Although the remains of pods are numerous, no seeds were detected. Contrary to Pitsidia, in Kassanoi the vegetative remains of $P$. podocarpum are more abundant and display a wider range of leaflet variation, whereas pods are lacking completely. From Makrilia, Sachse (2004) described a few leaflets of this taxon. Podocarpium podocarpum is an extinct genus of the Leguminosae family (Herendeen, 1992a, b; Wang et. al, 2007). According to Herendeen (1992a), it is one of the few species in the European Neogene that possibly is related to modern African taxa, which would be biogeographically remarkable. In Central Europe it was abundant, mainly in late early to middle Miocene plant assemblages.

\section{Subfamily Mimosoideae}

\section{Genus Mimosites Bowerbank}

\section{Mimosites sp.}

$$
\text { Pl. 10, figs 18-22 }
$$

Material. Pitsidia, 13 complete leaflets and 2 fragmentary (Nrs 31.4.2.2305ii; 31.4.2.2371; 31.4.2.3075aiii,biii; 31.4.2.3338ii;

31.4.2.4087aii,bi; 31.4.2.4346ai,b;

31.4.2.4389aii,bii; 31.4.2.4398ai,b; 31.4.2.4417;

31.4.2.4574; 31.4.2.4750ii; 31.4.2.5324;

31.4.2.5505; 31.4.2.6006op; 31.4.2.6946).

Description. Leaflets, small, short-petiolulate, petiolule $\sim 0.5 \mathrm{~mm}$ long and $0.3-0.5 \mathrm{~mm}$ wide, with prominent wrinkled pulvinus, lamina strongly asymmetric, elliptic to oblong, rarely ovate to lanceolate, $5-10.5 \mathrm{~mm}$ long and $2-3.5 \mathrm{~mm}$ wide, $\mathrm{L} / \mathrm{W}$ ratio $1.5-3.5$, apex obtuse to rounded, often mucronate, base rounded or slightly cordate, asymmetric, margin entire; venation brochidodromous, primary vein thick, dividing the lamina into two distinctly unequally broad, straight or slightly curved parts; secondary veins thin, 5-6 pairs poorly visible except for basal secondaries, which are strongly curved upwards; secondaries originating at wide angles, looping near margin, tertiary veins reticulate.

Remarks. The venation architecture and especially the strongly asymmetric lamina with a wrinkled petiolule indicate a Fabaceae affinity of this foliage (Herendeen, 1992b). Furthermore, the size of the lamina and its asymmetry are characteristic of "mimosoid" leaflets. A more precise classification is not possible currently. From Makrilia, Sachse (2004) reported a few lanceolate leaflets of possible Mimosoideae origin (?Mimosites sp., Pl. 12, figs 4, 6; Pl. 20, fig. 31) which differ from the material at hand by the rather narrow lamina with an acute apex. 


\section{Family Rosaceae}

Rosaceae gen. et sp. indet. type 1 - folia

$$
\text { Pl. 11, fig. } 14
$$

Material. Pitsidia, one lateral leaflet, complete (Nr. 31.4.2.6166a,b).

De s c ri p ti o n. Lateral leaflet, subsessile, lamina somewhat asymmetric, elliptic to obovate, $32 \mathrm{~mm}$ long and $17 \mathrm{~mm}$ wide, $\mathrm{L} / \mathrm{W}$ ratio 1.9 , base rounded, apex widely acute, margin simple serrate in upper $2 / 3$, entire near base; teeth acute, triangular, basal side convex to straight, rarely flexuous, apical side concave to straight, tooth spacing regular, $3-5$ per $\mathrm{cm}$, sinus between teeth mostly angular, very narrow; venation craspedodromous, primary vein stout, slightly bent; secondary veins delicate, in 7-8 pairs, \pm curved, often forked close to margin, higher-order venation not preserved.

Re marks. The serrate margin and the venation pattern point to a Rosaceae affinity. This family shows high diversity in leaf form. An identification to genus level is difficult when based solely on the gross morphology of isolated leaflets.

Rosaceae gen. et sp. indet. type 2 - folia

$$
\text { Pl. 11, figs 12, } 13
$$

Material. Kassanoi, one complete and one fragmentary leaf (Nrs 31.6.2.18ai,bi; 31.6.2.119vi).

Description. Leaf shortly petiolate, petiole $1 \mathrm{~mm}$ long, lamina chartaceous, obovate, 19 to $>20 \mathrm{~mm}$ long and $11-13 \mathrm{~mm}$ wide, $\mathrm{L} / \mathrm{W}$ ratio $\sim 1.5$, base cuneate, apex obtuse, margin apically lobed, with two prominent lobes on each side, lobes convex on both sides, apex rounded; venation brochidodromous to craspedodromous, primary vein moderate, curved, secondary veins fine, in 9-10 pairs, straight or slightly bent, reaching apex of lobes or forming loops with adjacent secondaries, higher-order venation not visible.

R e m a rks. These small leaves with characteristic rounded lobes are morphologically close to various genera of the Rosaceae, such as Ribes L. and Crataegus Tournefort ex L.

\section{Family Rhamnaceae}

Genus Berchemia Necker ex de Candolle

Berchemia multinervis (A. Braun) Heer

Pl. 11, figs $15-17$

1836 Rhamnus multinervis A. Braun (in Buckland), p. 513 (Öhningen, Germany, middle Miocene).

1859 Berchemia multinervis (A. Braun); Heer, p. 77, pl. 128, figs 9-18 (Swiss Molasse, Switzerland, late Miocene).

1994a Berchemia multinervis (A. Braun) Heer; Kleinhölter, pl. 8, fig. 6; pl. 28 figs 7, 8 (Pyrgos and Zacharo basins, Peloponnese, Messinian).

1994b Berchemia multinervis (A. Braun) Heer; Kleinhölter, pl. 2, fig. 1 (Pyrgos and Zacharo basins, Peloponnese, Messinian).

Material. Kassanoi, one almost complete and three fragmentary leaves (Nrs 31.6.2.158ii; 31.6.2.163; 31.6.2.170iii; 31.6.2.173).

Des cription. Lamina ovate to broad elliptic, 30 to $\sim 37 \mathrm{~mm}$ long and 21 to $\sim 28 \mathrm{~mm}$ wide, $\mathrm{L} / \mathrm{W}$ ratio $\sim 1.5$, base rounded to slightly cordate, margin entire; venation eucamptodromous, primary vein strong, straight, secondary veins in 11-12 moderately thick pairs, arising at $40-60^{\circ}$, more acute angles distally, opposite to alternate, interspaced $2.5-4 \mathrm{~mm}$, parallel, initially straight (near base of lamina often weakly S-like) to gently curved, close to margin abruptly bent upwards, tertiary veins delicate, opposite percurrent, straight, 1620 per $\mathrm{cm}$, slightly S-like to almost straight, higher-order venation not visible.

Remarks. Leaves with such a characteristic venation pattern were classified by $\mathrm{A}$. Braun (in Buckland, 1836) to the genus Rhamnus L. Later they were transferred by A. Braun (1845) and Unger (1847) to the genus Karwinskia Zuccarini and, finally, Heer (1859) placed them in Berchemia. The exact systematic position of Berchemia multinervis remains unresolved, however, as its venation type occurs in different genera in Rhamnaceae. For such leaves, Jones, Dilcher (1980) proposed an extinct genus of Rhamnaceae, Berhamniphyllum (tribe Zizypheae).

Genus Ziziphus Miller

\section{Ziziphus paradisiaca (Unger) Heer}

Pl. 11, figs $18-20$ 
8-11; pl. 38, figs 1, ?2, ?3, 4-7 (Socka, Slovenia, Eocene).

1859 Zizyphus paradisiaca Unger; Heer, p. 74 (Socka, Slovenia, Eocene).

?1867 Cinnamomum rossmaessleri Heer; Unger, pl. 7, fig. 32 (Kimi, Euboea, early Miocene).

?2002a Ziziphus ziziphoides f. paradisiaca (Unger) Weyland; Velitzelos et al., pl. 7, fig. 32 (Kimi, Euboea, early Miocene).

2004 Dicotylophyllum sp. 3, Sachse, pl. 14, figs 7, 9, ?11, ?13, 14; pl. 20, figs ?39, 41, ?42 (Makrilia, E. Crete, Tortonian).

2007 cf. Ziziphus ziziphoides (Unger) Weyland; Zidianakis et al., figs 3N-P (Vrysses, W. Crete, Messinian).

Material. Metochia, one almost complete leaf, one incomplete, and one fragment (Nrs 31.5.2.13ai,b; 31.5.2.15; 31.5.2.57).

Description. Leaf petiolate, petiole partly preserved, >2 mm long; lamina ovate to broadly elliptic, 30-33 mm long (when complete) and $16-19 \mathrm{~mm}$ wide, $\mathrm{L} / \mathrm{W}$ ratio $1.7-1.9$, base widely convex to almost rounded, apex acuminate, entire-margined in lower 1/4 of lamina, simply, obtusely serrate to undulate in further part; teeth few, spaced at intervals of $\sim 4-7 \mathrm{~mm}$, basal side mostly convex, apical side convex to straight, apex obtuse to bluntly acute, tooth height $\sim 1 \mathrm{~mm}$, sinus shallow, narrow, angular to rounded; venation basal acrodromous, central primary vein straight to gently curved, lateral primary veins thinner, arising directly from the petiole-midrib fusion point at $30-50^{\circ}$ from central vein, running subparallel to margin, closer to margin than to midvein, reaching apex of lamina, interior secondary veins delicate, weakly developed, dense, originating at wide angles, straight, anastomosing with tertiary veins and forming an irregular polygonal network; minor secondaries numerous, hardly visible, originating at wide angles, initially almost straight, close to margin forked, forming loops with adjacent secondaries or intersecondaries, sending veinlets to margin, one of the veinlets inserting the tooth sinus.

Remarks. The shape and arrangement of the marginal teeth and especially the vein architecture (weakly developed interior secondaries merging with tertiaries) point towards Rhamnaceae affinity (Paliurus, Ceanothus and especially Ziziphus). The figured specimens show the leaf form characteristic of $Z$. paradisiaca, well known as an accessory element at several European localities and dominant in only a few floras such as Mecsek (Hungary) and Radoboj (Croatia) (Heer, 1859; Hably, 2020). Such leaves are common in the Cretan late Miocene. From Makrilia, Sachse, Mohr (1996: p. 164, Tab. 1, Pl. 3, figs 75-77) initially assigned such leaves to the Rhamnaceae, relating them to Ziziphus Miller, Paliurus Miller, Ceanothus L. and Colubrina Richard ex Brongniart. Sachse (2004) transferred them to incertae sedis as Dicotylophyllum sp. 3, recognizing more similarities with genera such as Lonicera L. (Caprifoliaceae) and Clematis L. (Ranunculaceae). Zidianakis et al. (2007) compared them to Ziziphus ziziphoides. All three-veined basal acrodromous specimens with a serrate or crenulate margin from these localities do not necessarily belong to a single species. For example, the leaf illustrated by Sachse (2004) on Pl. 14, fig. 14, showing a narrow cuneate base, is quite different from $Z$. paradisiaca.

\section{Family Ulmaceae}

\section{Genus Ulmus L.}

\section{Ulmus cf. plurinervia Unger}

Pl. 16, figs 1-4, 20; Fig. 15b, c, e

1847 Ulmus plurinervia Unger, p. 95, pl. 25, figs 1-4 (Parschlug, middle Miocene)

Material. Pitsidia, 4 complete or rather complete leaves and 9 fragmentary ones

(Nrs 31.4.2.2148a,bi; 31.4.2.2899; 31.4.2.3781i; 31.4.2.3950ai,bi; 31.4.2.4304a,b; 31.4.2.4557a,b; 31.4.2.4818; 31.4.2.5830a,b; 31.4.2.6277ai,b; 31.4.2.6318; 31.4.2.6383; 31.4.2.6935a,b; 31.4.2.8119). Kassanoi, 4 complete or almost complete leaves and 3 fragmentary ones $(\mathrm{Nrs}$ 31.6.2.68; 31.6.2.71; 31.6.2.78a,b; 31.6.2.79; 31.6.2.119iv; 31.6.2.119v; 31.6.2.237).

Description. Leaves shortly petiolate, petiole 4-5 mm long, thick, broader near base, slightly curved, in open angle with primary vein; lamina ovate to broad elliptic, $6-34 \mathrm{~mm}$ long and 4-23 mm wide, $\mathrm{L} / \mathrm{W}$ ratio $0.7-2.8$; apex bluntly acute to acuminate, base \pm asymmetric, rounded to subcordate, margin simple to double, finely serrate, teeth dense, broadly triangular, blunt or occasionally sharp, basal side mainly convex to straight or concave, apical side convex to slightly S-like; tooth apex bluntly acute, sinus angular, acute; venation craspedodromous, primary vein strong, straight or gently 
bent, tapering towards apex, secondary veins in 6 to $>12$ pairs, arising at $30-70^{\circ}$, straight or almost so, delicate, subparallel, often forked once, innervating the marginal teeth, tertiary veins percurrent, weakly developed, opposite or alternate, straight or S-like.

Remarks. For these specimens the generic position is evident by the asymmetric base, the shape and length of the petiole, the simple to double serrate margin and the forked secondaries. Morphologically similar taxa are $U$. carpinoides Goeppert and $U$. plurinervia Unger. Kvaček et al. (2002) examined material from both type localities (Sośnica and Parschlug). They considered more slender leaf forms, smaller size and fine serration to be characteristic of $U$. plurinervia as compared to

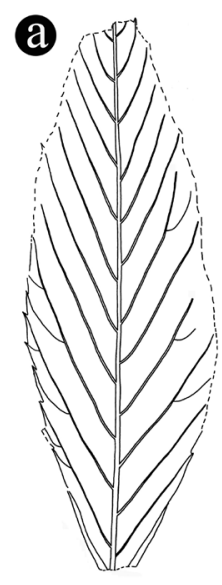

[]
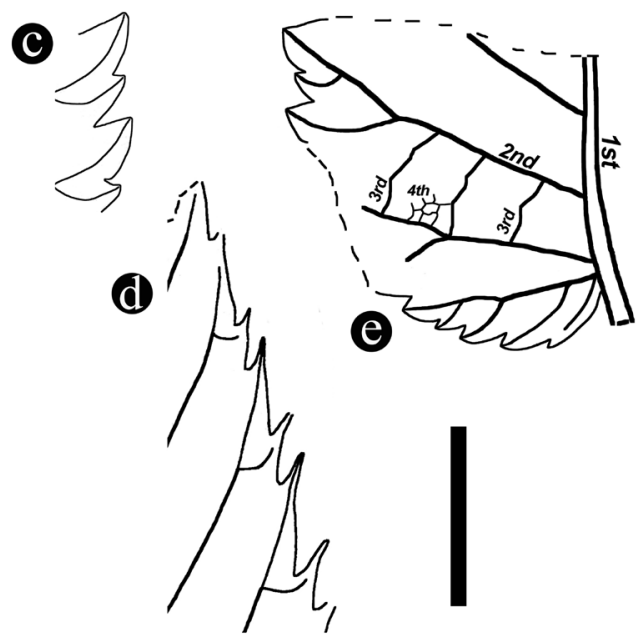

Fig. 15. Palaeoflora of Pitsidia. Ulmus and cf. Ostrya sp. foliage, line drawings, scale bar $=1 \mathrm{~cm}$ (unless otherwise stated); a. cf. Ostrya sp., note symmetric base and serrate margin, Nr. 31.4.2.8266; b. Ulmus cf. plurinervia, Nr. 31.4.2.3950ai; c. Ulmus cf. plurinervia, double serrate margin, Nr. 31.4.2.3950bi detail, scale bar $=3 \mathrm{~mm}$; d. cf. Ostrya sp., simple serrate margin, Nr. 31.4.2.6206b detail, scale bar $=3 \mathrm{~mm}$; e. Ulmus cf. plurinervia, margin and venation pattern of lamina base, Nr. 31.4.2.3950bi detail, scale bar $=5 \mathrm{~mm}$
$U$. carpinoides, which is usually larger, strongly asymmetric and broader, with a double serrate margin. Consequently, the examined foliage is closer morphologically to $U$. plurinervia.

Ulmus sp. - fructus

Pl. 16, fig. 5

Material. Pitsidia, one almost complete samara (Nr. 31.4.2.4150a,b).

Description. Samara shortly stalked, stalk $1 \mathrm{~mm}$ long, lacking any remnant of calyx; wings quite thin, almost circular in shape, $5.5 \mathrm{~mm}$ long and $5.0 \mathrm{~mm}$ wide, base broadly cuneate, apex indistinct, probably with doubleapex termination, marginal vein moderately strong, higher-order venation delicate, vaguely visible; endocarp broad elliptic, $4.0 \mathrm{~mm}$ long and $2.5 \mathrm{~mm}$ wide, seed slightly ovate, $1.7 \mathrm{~mm}$ long and $0.9 \mathrm{~mm}$ wide, positioned close to apex of fruit, with fine surface striation.

Remarks. The overall morphology of this winged fruit, the course of the prominent axial vein and the apex point towards Ulmus. The absence of the calyx remnant may be ascribed either to taphonomic factors or to its possibly deciduous nature (not persistent calyx). Similar winged fruits have been described by Goeppert (1855) from Sośnica, the type locality of Ulmus carpinoides (Pl. 14, figs 18-20). The winged fruit/seed from Makrilia which Sachse (2004) figured as Ulmus sp. (Pl. 17, fig. 24) is broader and bears more prominent venation.

Genus Zelkova Spach

\section{?Zelkova zelkovifolia \\ (Unger) Bůžek et Kotlaba}

Pl. 16, figs 6, 19

Material. Pitsidia, one almost complete leaf (Nr. 31.4.2.1663ai,bi).

Description. Lamina chartaceous, oblong to ovate, $41 \mathrm{~mm}$ long and $18 \mathrm{~mm}$ wide, $\mathrm{W} / \mathrm{L}$ ratio 2.3 , apex acute, base rounded, margin coarsely simple serrate; teeth, basal and apical sides convex, 1-2 mm long and wide, corresponding in number to secondary veins, sinus narrow angular; venation craspedodromous, primary vein slightly bent, moderately thick, secondaries delicate, arising at $40-70^{\circ}$, the steeper angles distally, straight or bent upwards, innervating 
the marginal tooth apex, close to the margin each secondary sending a veinlet to the apically adjacent sinus, tertiaries reticulate.

Remarks. The characteristic shape of the teeth and the pattern of second- and third-order venation point towards Zelkova zelkovifolia. The high number of teeth and more densely spaced secondary veins explain the hesitation to assign these remains unambiguously. In Crete, Sachse (2004) and Velitzelos D. et al. (2014) reported Z. zelkovifolia from Makrilia.

\section{Family Fagaceae}

\section{Genus Quercus L.}

\section{Quercus pseudocastanea}

Goeppert emend. Walther et Zastawniak

Pl. 12, figs 1-17; Fig. 16a-b

1852 Quercus pseudocastanea Goeppert, p. 276, pl. 35, fig. 1 (Sośnica, Poland, late Miocene).

1991 Quercus pseudocastanea (Goeppert); Walther, Zastawniak, p. 169, pl. 2, figs 2, 3, 5, 6; pl. 3, figs 1-6; text-fig. 8 (Sośnica, Poland, late Miocene).

1986 Quercus pseudocastanea Goeppert; Velitzelos, Knobloch, pl. 11, figs 2, 4, 7 (Skoura, Peloponnese, Pliocene).

1986b Quercus pseudocastanea Goeppert, Knobloch, Velitzelos, pl. 15, figs 1, 2 (Prosilio, W. Macedonia, Messinian).

1999 Quercus roburoides Massalongo; Velitzelos, Kvaček, pl. 1, fig. 5 (Vegora, W. Macedonia, Messinian).

1999 Quercus pseudocastanea Goeppert; Velitzelos et al., fig. D8 in p. 461 (Vegora, W. Macedonia, Messinian).

2002 Quercus pseudocastanea Goeppert emend. Walther et Zastawniak; Kvaček et al., pl. 13, figs $3-5$; pl. 14, figs 1, 2, 4-6; pl. 15, figs 1, 4, 6; pl. 30, fig. 4 (Vegora, W. Macedonia, Messinian).

2010 Quercus roburoides Massalongo; Zidianakis et al., fig. 2j (Pitsidia, central Crete, Tortonian).

2014 Quercus pseudocastanea Goeppert; Velitzelos D. et al., pl. 7, figs 5, 6, 8 (Grevena, W. Macedonia, early Miocene).

2014 Quercus pseudocastanea Goeppert; Velitzelos D. et al., pl. 15, fig. 6 (Vegora, W. Macedonia, Messinian).

2014 Quercus pseudocastanea Goeppert; Velitzelos D. et al., pl. 18, fig. 4 (Prosilio, W. Macedonia, Messinian).

2014 Quercus pseudocastanea Goeppert; Velitzelos D. et al., pl. 22, figs 5, 6 (Elassona, Thessaly, Messinian).

2014 Quercus pseudocastanea Goeppert emend. Walther et Zastawniak; Velitzelos D. et al., pl. 29, fig. 4 (Zeli, central Greece, Pliocene).
2014 Quercus pseudocastanea Goeppert; Velitzelos D. et al., pl. 30, figs 2, 3 (Skoura, Peloponnese, Pliocene).

2014 Quercus pseudocastanea Goeppert; Velitzelos D. et al., pl. 33, fig. 6 (Archangelos, Rhodes Island, Pleistocene).

Mat e r i a l. Pitsidia, 18 complete or almost complete leaves and 104 fragmentary ones (Nrs 31.4.2.322i; 31.4.2.824i; 31.4.2.853aii,bii; 31.4.2.874; 31.4.2.900; 31.4.2.918; 31.4.2.953i; 31.4.2.955; 31.4.2.1036a,b; 31.4.2.1138i; 31.4.2.1139; 31.4.2.1280a,b; 31.4.2.1405ii; 31.4.2.1419a,b; 31.4.2.1421ai,b; 31.4.2.1437i; 31.4.2.1578i; 31.4.2.1663aii,bii; 31.4.2.1663aiii,biii; 31.4.2.1709ai,b; 31.4.2.1715bviii; 31.4.2.1728; 31.4.2.1848; 31.4.2.1858; 31.4.2.1860; 31.4.2.1877; 31.4.2.2133i; 31.4.2.2135a,bi; 31.4.2.2135bop; 31.4.2.2137; 31.4.2.2159aiii,cii; 31.4.2.2164; 31.4.2.2266ai,b; 31.4.2.2276a,b; 31.4.2.2326ai,bi; 31.4.2.2431; 31.4.2.2756; 31.4.2.2834; 31.4.2.2941; 31.4.2.2960a,b; 31.4.2.3030ai,b; 31.4.2.3324; 31.4.2.3462a,b; 31.4.2.3636i; 31.4.2.3736ai,bi; 31.4.2.3807aii,bii; 31.4.2.3839; 31.4.2.3958ai,bi; 31.4.2.4010a,b; 31.4.2.4011; 31.4.2.4046; 31.4.2.4083bi; 31.4.2.4127a,b; 31.4.2.4135,4133aop; 31.4.2.4147ai,b; 31.4.2.4252; 31.4.2.4275ai,b; 31.4.2.4280ai,b; 31.4.2.4367a,b; 31.4.2.4457a,b; 31.4.2.4564a,b; 31.4.2.4641aiii,b; 31.4.2.4676; 31.4.2.4679; 31.4.2.4680; 31.4.2.4734a,b; 31.4.2.4735ai,bi; 31.4.2.4786a,b; 31.4.2.4820ai,b; 31.4.2.4852a,b; 31.4.2.4900a,bi; 31.4.2.4980ai,bi; 31.4.2.5021a,b; 31.4.2.5088a,b; 31.4.2.5092ai,b; 31.4.2.5217a,bi; 31.4.2.5313; 31.4.2.5357aop; 31.4.2.5446a,b; 31.4.2.5546; 31.4.2.5550; 31.4.2.5621,5620aop; 31.4.2.5681ai,bi; 31.4.2.5785ai,bi; 31.4.2.5817; 31.4.2.5883; 31.4.2.5945i; 31.4.2.5948a,b; 31.4.2.6003a,b; 31.4.2.6086; 31.4.2.6104ii; 31.4.2.6116i; 31.4.2.6123bop; 31.4.2.6152a,bi; 31.4.2.6152bii; 31.4.2.6178i; 31.4.2.6216aii,b; 31.4.2.6217ai,b; 31.4.2.6229a,b; 31.4.2.6494a,b; 31.4.2.6540i; 31.4.2.6617; 31.4.2.6802a,b; 31.4.2.6805; 31.4.2.6844aii,bii; 31.4.2.6866a,6873; 31.4.2.6867,6871b; 31.4.2.6933a,b; 31.4.2.6967; 31.4.2.8014opii; 31.4.2.8156ai,bi; 31.4.2.8157a,b; 31.4.2.8164; 31.4.2.8191a,b; 31.4.2.8193i; 31.4.2.8198ii; 31.4.2.8198iii; 31.4.2.8205; 31.4.2.8242ai,bi; 31.4.2.8242aii,bii; 31.4.2.8244i; 31.4.2.8271).

Description. Leaves petiolate, petiole slender, up to $25 \mathrm{~mm}$ long; lamina texture probably chartaceous, shape obovate to elliptic 

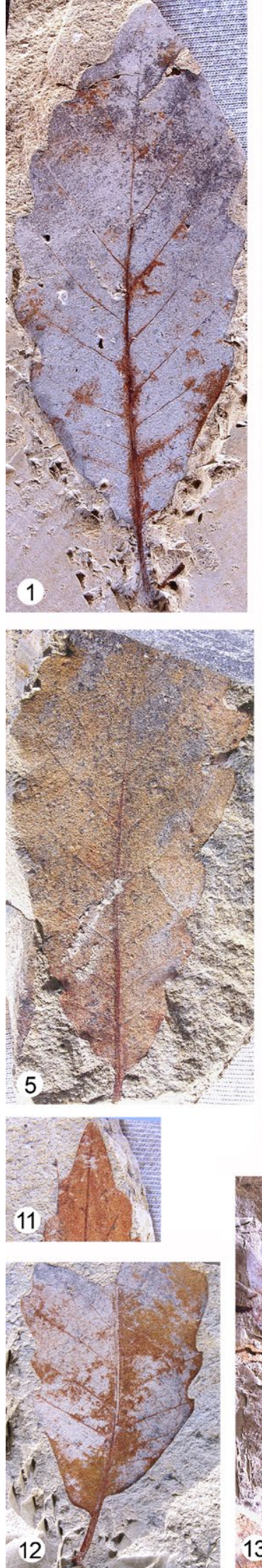
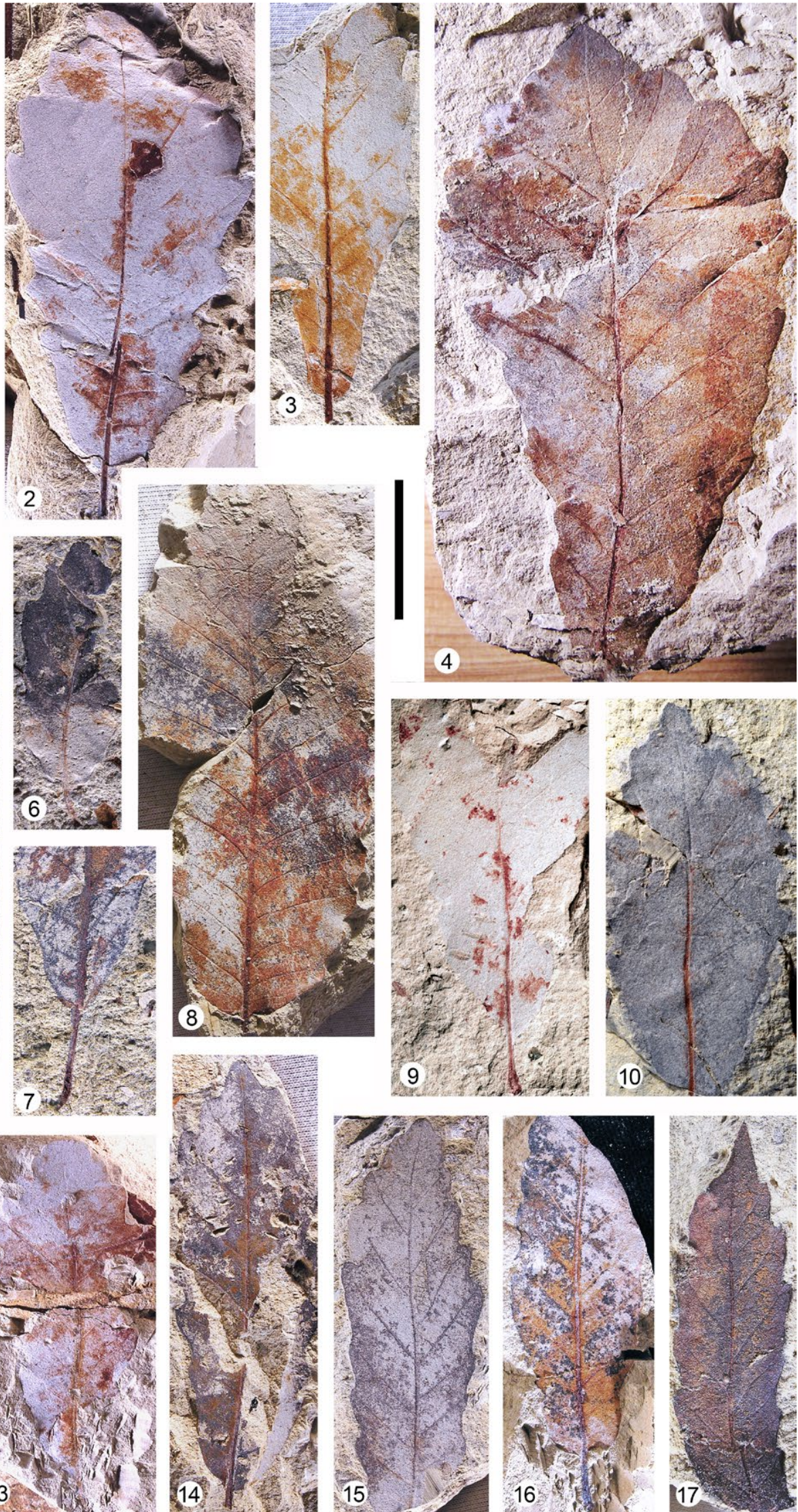

Plate 12. Palaeoflora of Pitsidia, scale bar $=2 \mathrm{~cm} ; 1$ 1-13. Quercus pseudocastanea Goeppert emend. Walther et Zastawniak, foliage, typical form; 1. Nr. 31.4.2.4786a; 2. Nr. 31.4.2.4820ai; 3. Nr. 31.4.2.4280ai; 4. Nr. 31.4.2.322i (Fig. 2j in Zidianakis et al., 2010); 5. Nr. 31.4.2.8191a; 6. small leaf, Nr. 31.4.2.5945i; 7. leaf base, Nr. 31.4.2.1139; 8. Nr. 31.4.2.1419 $\alpha$; 9. Nr. 31.4.2.8244i; 10. Nr. 31.4.2.5785bi; 11. leaf apex, Nr. 31.4.2.2137; 12. leaf base, Nr. 31.4.2.6933a; 13. damaged by sediment fracturing, Nr. 31.4.2.4011; 14-17. Quercus pseudocastanea Goeppert emend. Walther et Zastawniak, foliage, narrow form; 14. Nr 31.4.2.4641b; 15. Nr. 31.4.2.5681ai; 16. Nr. 31.4.2.4564b; 17. Nr. 31.4.2.1138i 
or oblanceolate, 32-92 $\mathrm{mm}$ (average $58 \mathrm{~mm}$ ) long and $13-51 \mathrm{~mm}$ (average $24.2 \mathrm{~mm}$ ) broad, $\mathrm{L} / \mathrm{W}$ ratio $1.5-3.4$, base symmetric to asymmetric, mostly acute, cuneate to rounded, rarely subcordate, apex acute to acuminate, margin coarsely simply lobate, often entire in basal third; lobes rounded, basal side flexuous to convex, apical side \pm convex, lobe apex occasionally pointed, sinuses shallow, rounded; venation craspedodromous, midvein straight or bent, moderately strong, secondary veins mainly alternate to more rarely subopposite, near their origin narrowing the midvein then curving outwards, diverging and further running straight or curved towards margin, ending in the lobe apices, in 7-13 pairs, originating mostly at $30-60^{\circ}$, interspaced $\sim 4-10 \mathrm{~mm}$, tertiary veins fine, percurrent, opposite or alternate, straight or sinuous, almost at right angles to secondaries, higher venation forming a polygonal net.

Remarks. The leaf variability well matches that of $Q$. pseudocastanea from Sośnica as emended by Walther, Zastawniak (1991), including $Q$. pseudorobur Kováts and $Q$. hispanica Rérolle, although the leaves are smaller. Q. roburoides, which is common in the European Pliocene, is morphologically very similar, usually differing in having deeper marginal lobes. Some leaves diverge morphologically from the typical form described from Pitsidia, having an elongated, narrower lamina (Pl. 12, figs 14-17). Because of the wide leaf variation of modern oak species, these leaves are included in $Q$. pseudocastanea as a distinct narrow leaf form. In modern oaks it is difficult to differentiate leaf species based on gross morphology. Therefore $Q$. pseudocastanea should better be considered as a species complex. In Central Europe, Q. pseudocastanea occurs from the middle Miocene to late Pliocene (Kovar-Eder et. al., 1994).

\section{Quercus kubinyii}

(Kováts ex Ettingshausen) Czeczott

$$
\text { Pl. 13, figs 1-18; Fig. 16c-g }
$$

1852 Castanea kubinyii (Kováts ex Ettingshausen), p. 5, pl. 1, fig. 12 (Erdóbénye, Hungary, middle Miocene).

1951 Quercus kubinyii (Kováts ex Ettingshausen); Czeczott, p. 392, fig. 7 (Zalesce, Poland, middle Miocene).

?2010 Quercus cf. kubinyii (Kováts ex Ettingshausen) Czeczott; Zidianakis et al., fig. 2k (Pitsidia, central Crete, Tortonian).
Material. Pitsidia, 16 complete or almost complete leaves and 27 fragmentary ones (Nrs 31.4.2.007; 31.4.2.831; 31.4.2.850a,b; 31.4.2.852; 31.4.2.870a,b; 31.4.2.956; 31.4.2.971a,b; 31.4.2.1087; 31.4.2.1094; 31.4.2.1416a,b; 31.4.2.1420a,b; 31.4.2.2200a,b; 31.4.2.2426a,b; 31.4.2.2705aop,b; 31.4.2.2914a,b; 31.4.2.2926a,b; 31.4.2.3374a,b; 31.4.2.3534a,3543aopi; 31.4.2.3806ai,bi;

31.4.2.3828,3516; 31.4.2.3922i; 31.4.2.3922ii; 31.4.2.4124; 31.4.2.4140a,b; 31.4.2.4161opi,4147opai; ?31.4.2.4189ai,b; 31.4.2.4360ai,bi; 31.4.2.4621a,b; 31.4.2.4646a,b; 31.4.2.5112aiop; 31.4.2.5177a,bi; 31.4.2.5462a,b; 31.4.2.6070,6141ii; 31.4.2.6938ai,bi; 31.4.2.6986ai,bi; 31.4.2.7037a,b; 31.4.2.8176ai,bi; 31.4.2.8192a,b; 31.4.2.8197; 31.4.2.8238; 31.4.2.8265; 31.4.2.8267; 31.4.2.8270).

Description. Leaves petiolate, petiole moderately thick, $10-27 \mathrm{~mm}$ long; lamina oblong to lanceolate or somewhat ovate, 25 to $>94 \mathrm{~mm}$ long and $11-47 \mathrm{~mm}$ wide, $\mathrm{L} / \mathrm{W}$ ratio $1.7-3.9$, base rounded, slightly cordate to broadly cuneate, \pm symmetric, apex acute to acuminate, margin simply dentate; teeth narrow, \pm triangular and mostly large, basal side concave or occasionally straight to retroflexuous, apical side convex, less frequently straight to flexuous, tooth apex acute to mucronate, sinus mainly deep, rounded to subangular; venation craspedodromous, primary vein stout, straight or smoothly curved basically or apically, secondary veins alternate to almost opposite, in 10-15 pairs, originating at $35-80^{\circ}$, angle decreasing towards apex, interspaces regular, distances 3-9 mm, course subparallel, unbranched, straight, occasionally bent along their length exmedially, tertiary veins dense, percurrent, opposite or alternate, straight to sinuous, usually perpendicular to secondaries; quaternary veins forming a polygonal network.

Remarks. These oak leaves, with sharp triangular teeth, also resemble $Q$. gigas Goeppert emend. Walther et Zastawniak. The affinity to Q. kubinyii is more probable, based on the relatively smaller and slender leaves and variation in shape. From Makrilia, Sachse (2004) reported a narrow, coarsely dentate leaf fragment as ?Quercus kubinyii. The arced secondary veins of this specimen are not parallel and their course close to the margin is unknown. 


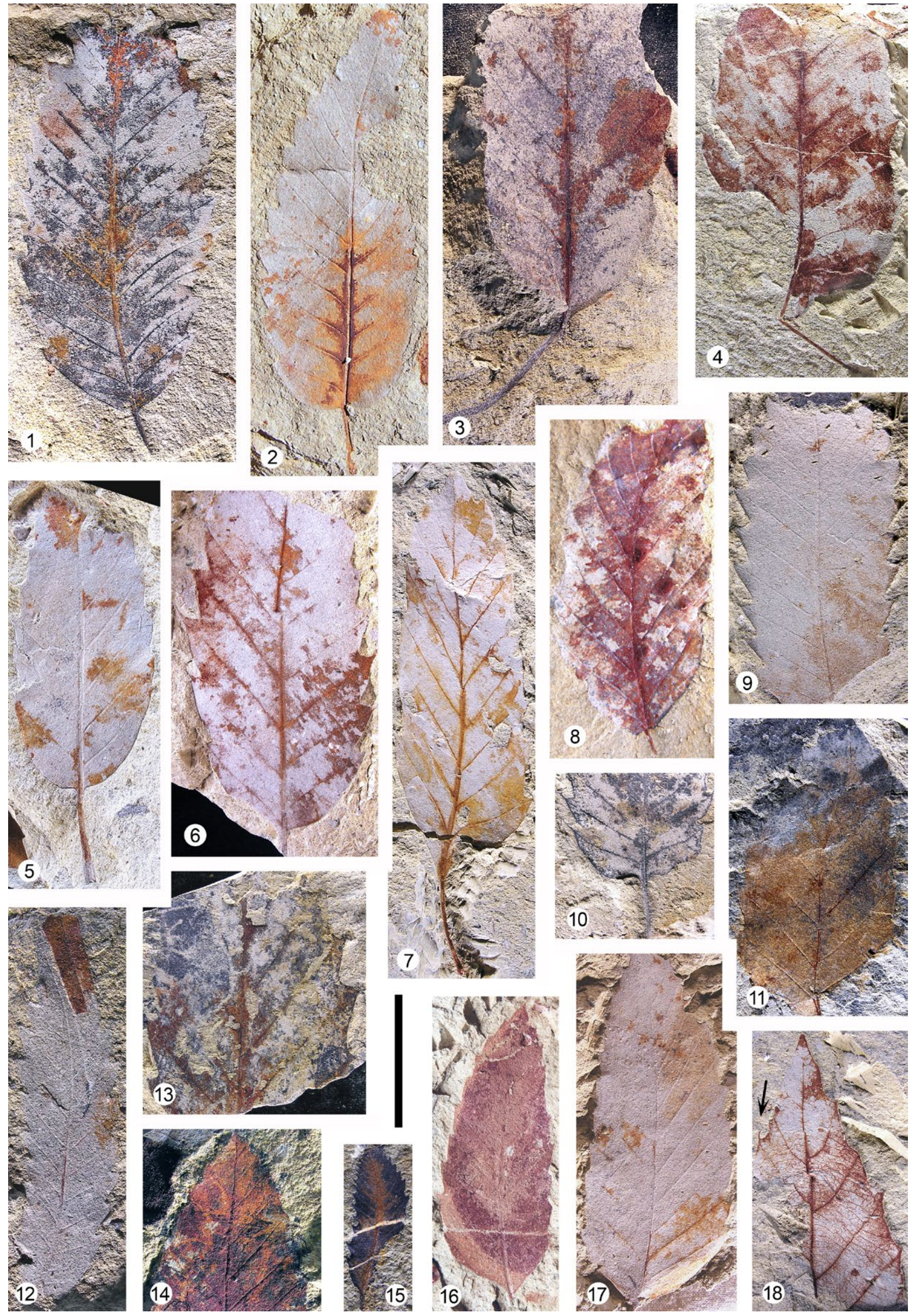

Plate 13. Palaeoflora of Pitsidia; 1-18. Quercus kubinyii (Kováts ex Ettingshausen) Czeczott, foliage, scale bar = $2 \mathrm{~cm} ; \mathbf{1}$. Nr. 31.4.2.4646a; 2. Nr. 31.4.2.8265; 3. Nr. 31.4.2.971a; 4. Nr. 31.4.2.4360bi; 5. Nr. 31.4.2.3806ai; 6. Nr. 31.4.2.2705aop; 7. Nr. 31.4.2.6938ai; 8. Nr. 31.4.2.007; 9. Nr. 31.4.2.6070; 10. Nr. 31.4.2.3828; 11. Nr. 31.4.2.2926b; 12. Nr. 31.4.2.8176bi; 13. Nr. 31.4.2.2426a; 14. Nr. 31.4.2.8197; 15. ?extreme leaf form, Nr. 31.4.2.8238; 16. Nr. 31.4.2.1416a; 17. Nr. 31.4.2.7037a; 18. note bristle-tipped tooth at upper part of lamina (arrow), Nr. 31.4.2.1420a 

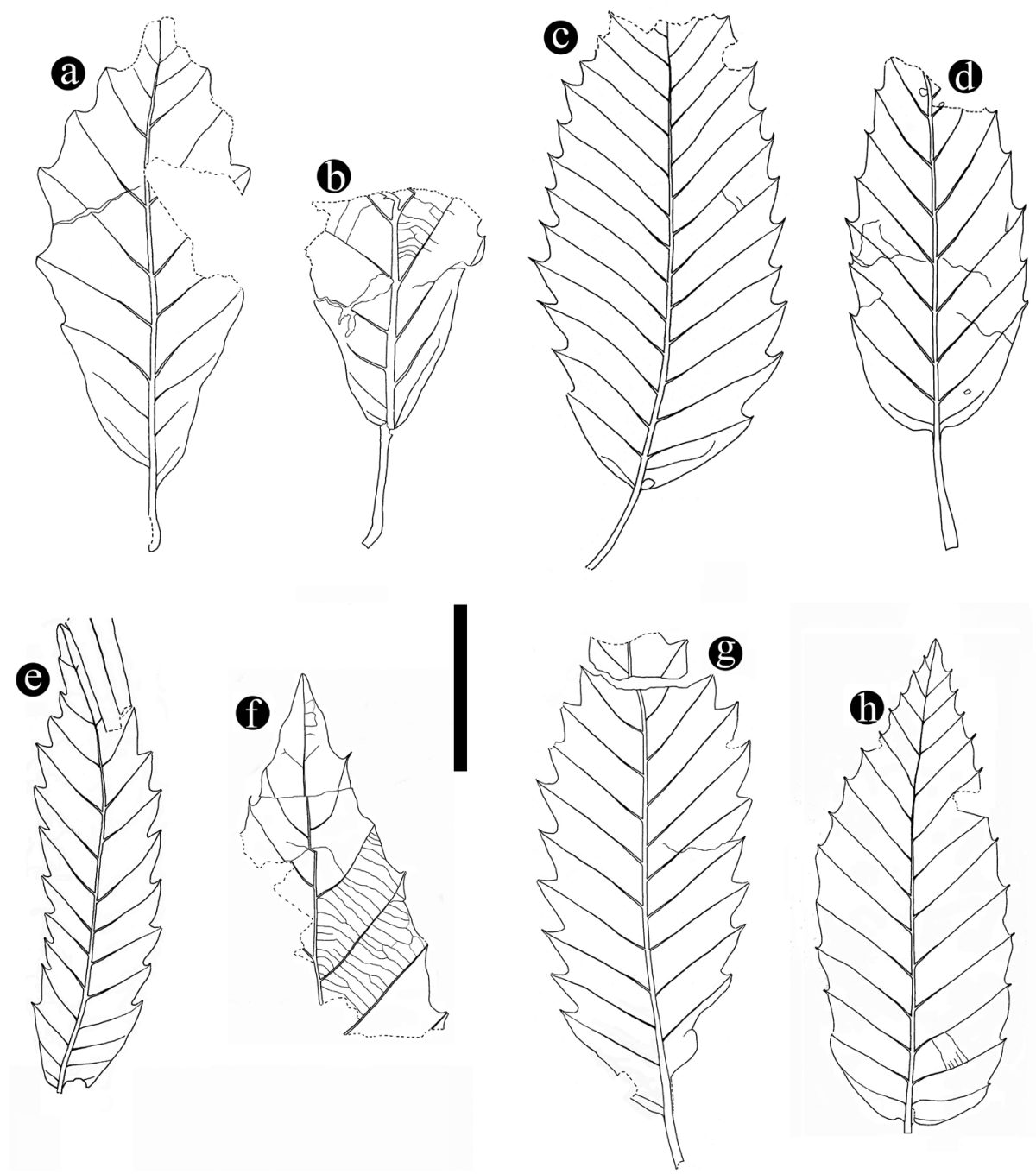

Fig. 16. Palaeoflora of Pitsidia. Fagaceae foliage, line drawings, scale bar $=2 \mathrm{~cm}$; a-b. Quercus pseudocastanea; a. Nr. 31.4.2.5785ai; b. leaf base, Nr. 31.4.2.1139; c-g. Quercus kubinyii; c. Nr. 31.4.2.4646b; d. Nr. 31.4.2.3806ai; e. Nr. 31.4.2.8176bi; f. lamina apex, Nr. 31.4.2.1420a; g. Nr. 31.4.2.6070,6141ii synthesis; h. Fagus gussonii, Nr. 31.4.2.7038

The assignment to $Q$. kubinyii is therefore uncertain. Especially during the late Miocene and Pliocene, Quercus kubinyii is known from numerous European sites and shows remarkable variation in leaf shape (Knobloch and Kvaček, 1976; Hably and Kvaček, 1997; Kvaček et al., 2002; Worobiec, 2003). However, records from the Greek peninsula and adjacent islands are restricted to Pitsidia and possibly Makrilia.

\section{Quercus mediterranea Unger}

Pl. 14, figs $1-5$

1847 Quercus mediterranea Unger, p. 114, pl. 32, figs 5-9 (Parschlug, Austria, middle Miocene).

?1862 Quercus mediterranea Unger; Unger, p. 158 (Kimi, Euboea, early Miocene) (no figure).

1867 Quercus mediterranea Unger; Unger, pl. 6, figs 1-22, pl. 13, figs 7-9 (Kimi, Euboea, early Miocene).
?1921 Quercus mediterranea Unger; Fritel, p. 472 (Oropos, Attica, early Miocene) (no figure).

1975 Quercus cf. ilex L.; Heimann et al., pl. 14, fig. 10 (Paghi, Corfu Island, Messinian).

1983 Quercus mediterranea Unger; Velitzelos, pl. 1, figs 2, 5, 6 (Pappades, Euboea, early Miocene).

?1985 Quercus mediterranea Unger; Dermitzakis, Velitzelos, p. 165 (Kato Komi, Chios Island, Serravallian-Tortonian) (no figure).

1985-86 Quercus mediterranea Unger; Dermitzakis et al., fig. 6.1 (Akropotamos, E. Macedonia, Messinian).

1986a Quercus cf. mediterranea Unger; Knobloch, Velitzelos, pl. 2, fig. 5 (Elassona, Thessaly, Messinian).

1986b Quercus cf. mediterranea Unger; Knobloch, Velitzelos, pl. 14, figs 4, 11; pl. 15, fig. 7 (Prosilio, W. Macedonia, Messinian).

1989 Quercus mediterranea Unger; Kvaček, Walther, text-figs 5a-b (Lava, W. Macedonia, Messinian).

1992 Quercus mediterranea Unger; Velitzelos et al., pl. 5, figs 1-15; pl. 7, figs 5-7; text-figs 5-7 (Aliveri, Euboea, early Miocene). 
1994a Quercus mediterranea Unger; Kleinhölter, pl. 6, fig. 1; pl. 23, figs 3, 6 (Pyrgos and Zacharo basins, Peloponnese, Messinian).

1996 Quercus mediterranea Unger; Sachse, Mohr, pl. 3, figs 9-11; pl. 5, fig. 5 (Makrilia, eastern Crete, Tortonian).

1999 Quercus mediterranea Unger; Velitzelos, Kvaček, pl. 1, fig. 7 (Vegora, W. Macedonia, Messinian).

2002 Quercus mediterranea Unger; Kvaček et al., pl. 10, figs 7, 9-11; pl. 31, figs 1, 2 (Vegora, W. Macedonia, Messinian).

2004 Quercus mediterranea Unger; Sachse, pl. 10, figs 4, 5, 8; pl. 19, figs 10, 11 (Makrilia, E. Crete, Tortonian).

2007 Quercus mediterranea Unger; Zidianakis et al., figs $2 \mathrm{H}-\mathrm{K}, 5 \mathrm{~J}$ (Vrysses, W. Crete, Messinian).

2010 Quercus mediterra.nea Unger; Zidianakis et al., fig. $2 \mathrm{~m}$ (Pitsidia, central Crete, Tortonian).

2014 Quercus mediterranea Unger; Velitzelos D. et al., pl. 18, fig. 3 (Prosilio, W. Macedonia, Messinian).

Material. Pitsidia, 4 complete or almost complete leaves and 5 fragmentary ones (Nrs ?31.4.2.271a,b; 31.4.2.272; 31.4.2.2159bii; 31.4.2.3732ai,bi; 31.4.2.4230; 31.4.2.4565a,b; 31.4.2.5183a,b; 31.4.2.5812a,b; 31.4.2.5813a,b). Metochia, one complete and one fragmentary leaf (Nrs 31.5.2.7; 31.5.2.59).

Description. Leaves short petiolate, petiole 0.5-4 $\mathrm{mm}$ long, lamina broad elliptic to obovate, 13-35 $\mathrm{mm}$ long and 9-20 mm wide, $\mathrm{L} / \mathrm{W}$ ratio $1.4-2.2$, base \pm rounded, apex obtuse to acute or shortly acuminate, margin entire near base, irregularly simpe serrate in upper half of lamina, teeth small with acute apices, sinuses wide, rounded; venation craspedodromous or eucamptodromous (in entire-margined part), primary vein stout, secondary veins strong, almost opposite to alternate, in 6-9 pairs, originating at $25-85^{\circ}$, angle decreasing distally, irregularly spaced, straight or curved, mostly not parallel, occasionally forked, running towards margin, entering teeth, tertiary veins opposite percurrent, straight or curved.

Remarks. These irregularly simple serrate leaves, which are smaller than the aforedescribed oaks, are characteristic of Quercus mediterranea. Based on leaf morphology, Denk et al. (2017) proposed a relation to Quercus, Group Ilex. Except for Kassanoi, Q. mediterranea has been reported from all Neogene floras of Crete (Sachse, 2004; Zidianakis et al., 2007). Especially in Vrysses, this oak is one of the dominant species. In contrast, in Pitsidia and Metochia it is rather rare.

\section{Quercus sp. - folia}

Pl. 14, figs 6, 7

Material. Kassanoi, three leaf fragments (Nrs 31.6.2.113i; 31.6.2.166ai,b; 31.6.2.167).

Description. Lamina probably obovate, $>46 \mathrm{~mm}$ long and >31 wide, base and apex missing, margin lobed; venation craspedodromous, primary vein strong, secondary veins moderately thick, originating at $45-55^{\circ}$, bent, innervating the lobes, tertiary veins dense, perpendicular to secondaries, percurrent, \pm opposite, curved or S-like, higher-order venation not preserved.

Remarks. The gross morphology of these specimens suggests a deciduous oak.

\section{Genus Fagus L.}

\section{Fagus gussonii}

Massalongo emend. Knobloch et Velitzelos

Pl. 14, figs 8-10; Fig. 16h

1859 Fagus gussonii Massalongo in Massalongo, Scarabelli, p. 202, pl. 25, figs 2, 5 (Senigallia, Italy, late Miocene).

1859 Fagus marsilii Massalongo in Massalongo, Scarabelli, p. 201, pl. 9, fig. 19; pl. 21, fig. 18 (Senigallia, Italy, late Miocene).

1986a Fagus gussonii Massalongo; Knobloch, Velitzelos, p. 9, pl. 2, figs 2-4, 6-8; pl. 5, fig. 11; pl. 6, fig. 5 (Elassona, N. Thessaly, Messinian).

1986b Fagus gussonii Massalongo; Knobloch, Velitzelos, pl. 14, fig. 2 (Prosilio, W. Macedonia, Messinian).

1987 Fagus gussonii Massalongo; Knobloch, Velitzelos, pl. 1, fig. 5 (Elassona, N. Thessaly, Messinian).

1996 Fagus sp., aff. Alnus sp.; Sachse, Mohr, pl. 3, figs 1, 2, 5 (Makrilia, E. Crete, Tortonian).

2002 Fagus gussonii Massalongo emend. Knobloch et Velitzelos; Kvaček et al., pl. 5, figs 3-9; pl. 6, figs 1-7; pl. 7, figs 1-5; pl. 29, figs 3, 4 (Vegora, W. Macedonia, Messinian).

2004 Fagus gussonii Massalongo emend. Knobloch et Velitzelos; Denk, pl. 12, figs B-F, I, K (Vegora, W. Macedonia, Messinian).

2004 Fagus gussonii Massalongo; Denk, pl. 12, figs G-H (Elassona, N. Thessaly, Messinian).

2004 Fagus gussonii Massalongo; Denk, pl. 12, fig. L (Makrilia, E. Crete, Tortonian).

2004 Fagus type gussonii, Fagus type attenuata; Sachse, pl. 10, figs 1, 2, 6, pl. 19, figs 1, 2, 5 (Makrilia, E. Crete, Tortonian).

?2010 Fagus type attenuata; Zidianakis et al., fig. 2i (Pitsidia, central Crete, Tortonian).

2014 Fagus gussonii Massalongo; Velitzelos D. et al., pl. 15, fig. 4 (Vegora, W. Macedonia, Messinian). 

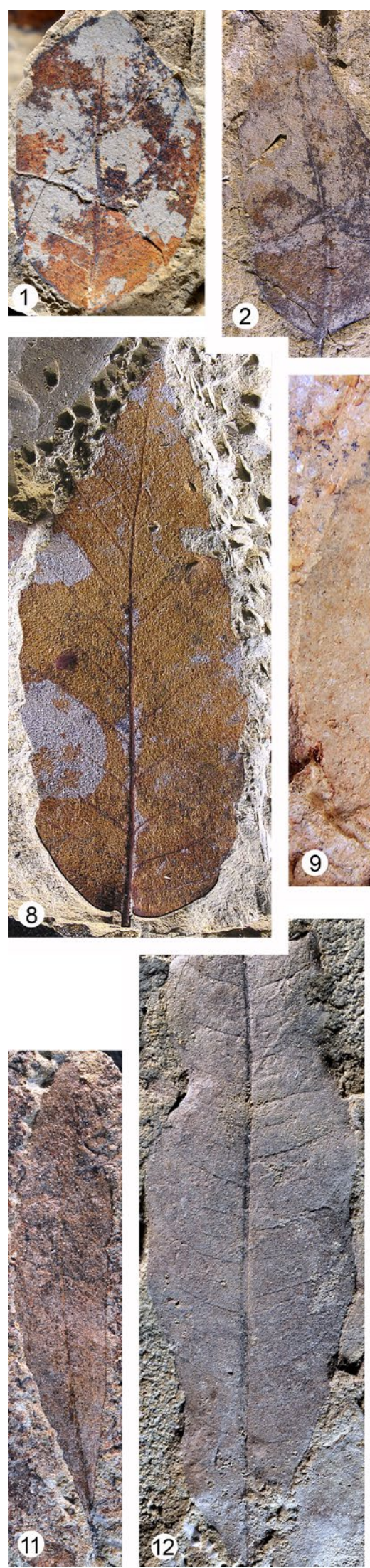
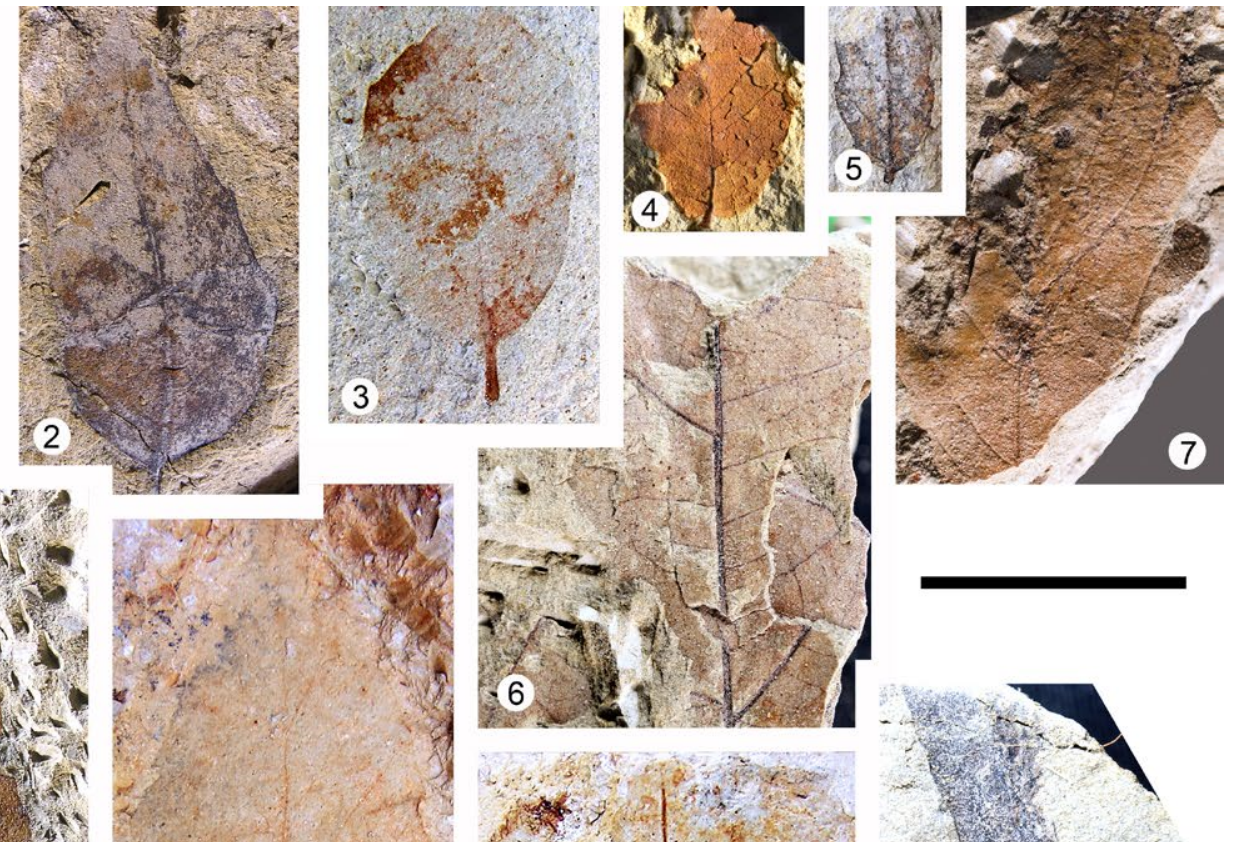
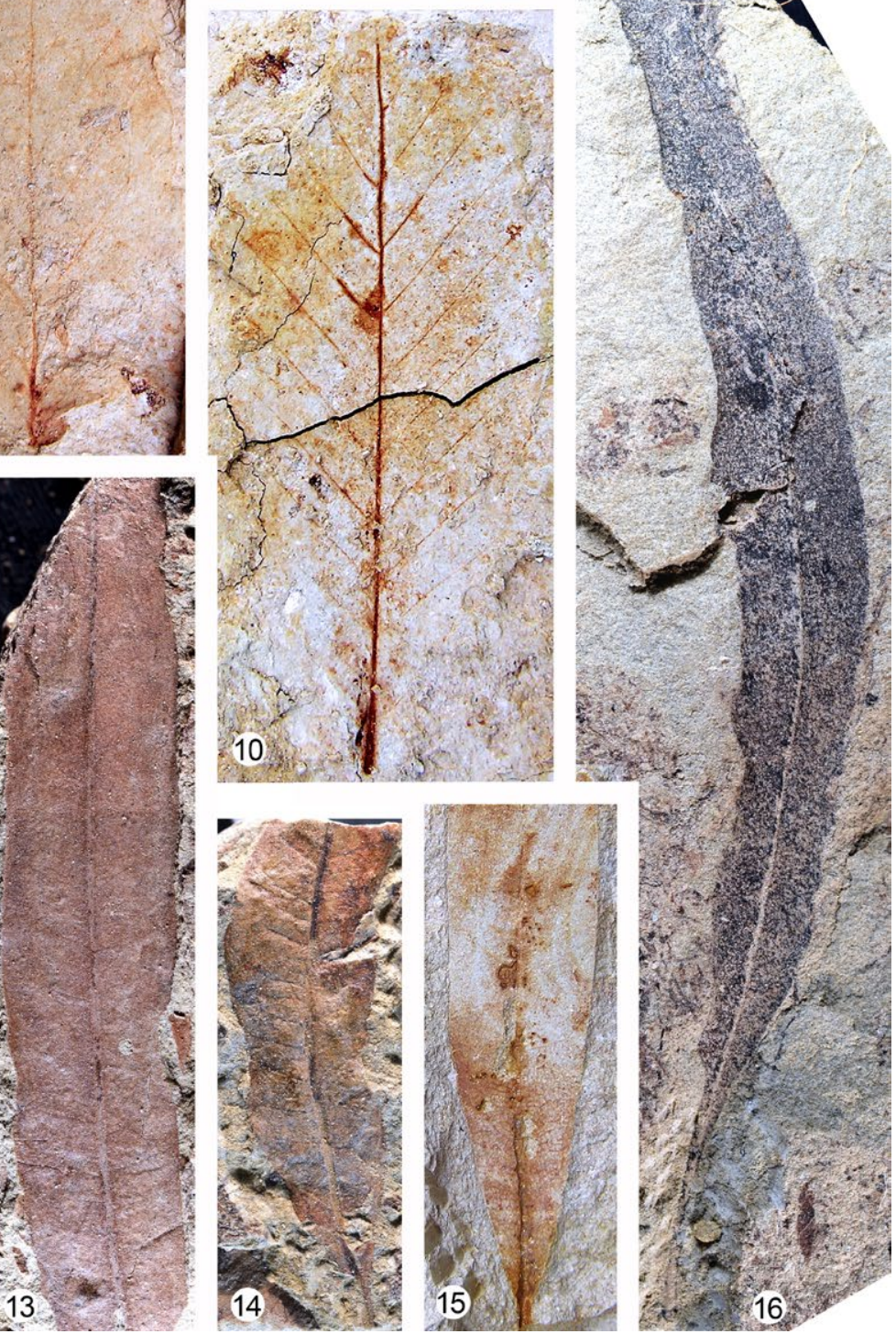

Plate 14. Cretan palaeofloras, scale bar $=2 \mathrm{~cm}$ (unless otherwise stated); 1-5. Quercus mediterranea Unger, foliage; 1. Pitsidia, Nr. 31.4.2.2159bii; 2. Pitsidia, Nr. 31.4.2.5812a; 3. Metochia, Nr. 31.5.2.59; 4. small leaf, Pitsidia, Nr. 31.4.2.5183a, scale bar $=1.5 \mathrm{~cm}$; 5. small leaf, Metochia, Nr. 31.5.2.7, scale bar $=1.5 \mathrm{~cm} ; \mathbf{6}, \mathbf{7}$. Quercus sp., foliage, Kassanoi; 6. Nr. 31.6.2.166ai; 7. Nr. 31.6.2.113i; 8-10. Fagus gussonii Massalongo emend. Knobloch et Velitzelos, foliage, 8. Pitsidia, Nr. 31.4.2.7038; 9. Metochia, Nr. 31.5.2.2; 10. Metochia, Nr. 31.5.2.21a; 11-16. Myrica lignitum (Unger) Saporta, foliage; 11. Kassanoi, Nr. 31.6.2.40; 12. Myrica ?lignitum (Unger) Saporta, Kassanoi, Nr. 31.6.2.95; 13. Kassanoi, Nr. 31.6.2.80i; 14. leaf base, Kassanoi, Nr. 31.6.2.69ii; 15. leaf base, Metochia, Nr. 31.5.2.46; 16. Kassanoi, Nr. 31.6.2.33ii 
2014 Fagus gussonii Massalongo; Velitzelos D. et al., pl. 17, fig. 7 (Prosilio, W. Macedonia, Messinian).

2014 Fagus gussonii Massalongo; Velitzelos D. et al., pl. 21, fig. 11 (Elassona, N. Thessaly, Messinian).

2015 Fagus gussonii Massalongo emend. Knobloch et Velitzelo; Mantzouka et al., figs 4.1-4.3 (Metochia, Gavdos Island, Tortonian).

Material. Pitsidia, 2 complete or almost complete leaves and 9 fragmentary ones (Nrs 31.4.2.1176ai,bi; 31.4.2.2316; 31.4.2.3870a,b; 31.4.2.3960; 31.4.2.4153a,b; 31.4.2.4339aiii; 31.4.2.4340ai,b;?31.4.2.6125iii;31.4.2.6241ai,b; 31.4.2.6387a,b; 31.4.2.7038). Metochia, 3 complete to almost complete leaves and 11 fragmentary ones (Nrs 31.5.2.2; 31.5.2.17; 31.5.2.18; 31.5.2.20; 31.5.2.21a,b; 31.5.2.22; 31.5.2.23; 31.5.2.24; 31.5.2.25; 31.5.2.26; 31.5.2.27a,b; 31.5.2.28a,b; 31.5.2.29ai,b; 31.5.2.32a,b).

Description. Leaves petiolate, petiole $>6-8 \mathrm{~mm}$ long, lamina probably chartaceous, oblong to ovate or elliptic, $\sim 40$ to $>82 \mathrm{~mm}$ long and 20 to $>62 \mathrm{~mm}$ wide, $\mathrm{L} / \mathrm{W}$ ratio $\sim 2-2.4$, base cuneate to rounded, apex acute, margin simple dentate, with small, sharp teeth alternating with open, shallow, rounded to S-like sinuses; venation craspedodromous, primary vein strong, straight to gently curved, often slightly sinuous near leaf apex, secondary veins delicate, alternate to subopposite, in 10-15 pairs, regularly spaced, arising at $30-80^{\circ}$, interspacing 2-8 $\mathrm{mm}$, angles and distances decreasing towards apex, course parallel to subparallel, straight, unbranched, entering marginal teeth, tertiary veins dense, opposite or alternate percurrent, oblique or perpendicular to secondaries, sinuous or straight.

Remarks. The marginal serration, craspedodromous venation, strictly straight and parallel secondary veins and the size of the lamina correspond with Fagus gussonii. This species is distributed mainly in southern Europe and Anatolia (Denk, 2004). It is very common especially in the late Miocene floras of Italy and northern Greece and in the middle Miocene floras of the Yatağan Basin in Turkey (Massalongo and Scarabelli, 1859; Knobloch and Velitzelos, 1986, Güner et al., 2017). From Crete, Sachse (2004) and Mantzouka et al. (2015) described several leaf remains of $F$. gussonii from Makrilia and Metochia. In Vrysses and Kassanoi this element has not yet been detected.
Family Myricaceae

Genus Myrica L.

\section{Myrica lignitum (Unger) Saporta}

Pl. 14, figs 11-16; Fig. 17a,b

Material. Pitsidia, (in Zidianakis, 2018). Kassanoi, 8 complete or almost complete leaves and 20 fragmentary ones $(\mathrm{Nrs}$ 31.6.2.16v; 31.6.2.33ii; 31.6.2.40; 31.6.2.41; 31.6.2.46; 31.6.2.47; 31.6.2.50; 31.6.2.69ii; 31.6.2.80i; $31.6 .2 .82 ; \quad 31.6 .2 .88 ; \quad 31.6 .2 .89$; 31.6.2.91iii; 31.6.2.94; ?31.6.2.95; 31.6.2.99; 31.6.2.106; 31.6.2.107i; 31.6.2.107ii; 31.6.2.109; 31.6.2.119viii; $\quad 31.6 .2 .120 \mathrm{i} ; \quad 31.6 .2 .120 \mathrm{ii}$; 31.6.2.123ii; $\quad 31.6 .2 .123 \mathrm{iii} ; \quad 31.6 .2 .124 \mathrm{ii} ;$ 31.6.2.217; 31.6.2.245opii). Metochia, 2 incomplete leaves (Nrs 31.5.2.46; 31.5.2.48ai,b).

Description. See Zidianakis et al. (2015)

Remarks. From Pitsidia the evidence of Myrica comprises not only leaves but also catkins, fruits and infructescences in a remarkable state of preservation; they have already

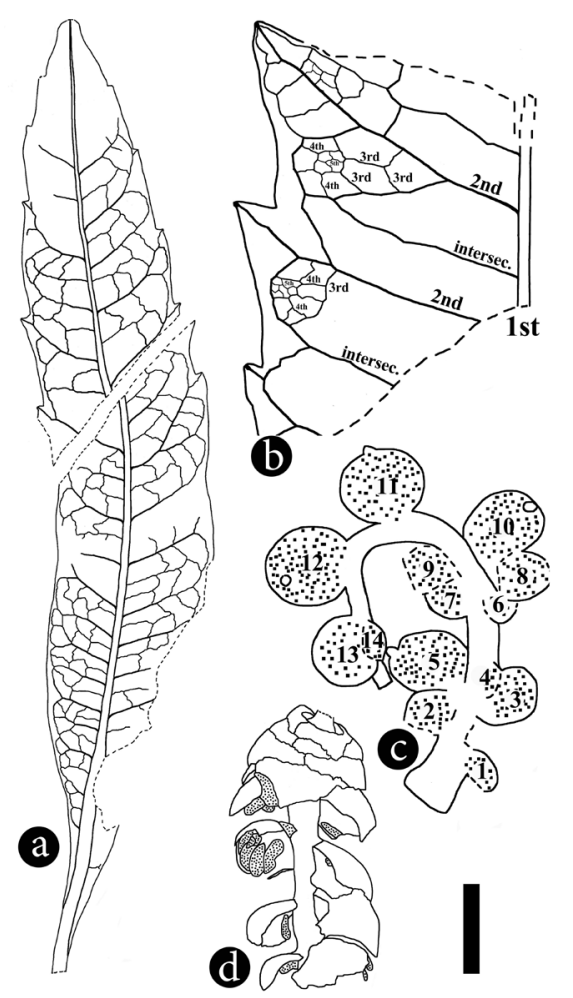

Fig. 17. Palaeoflora of Pitsidia. Myrica vegetative and fertile organs, line drawings, scale bar $=2.5 \mathrm{~mm}$ (unless otherwise stated); a. complete leaf of M. lignitum, Nr. 31.4.2.3782bii, scale bar $=6 \mathrm{~mm}$; b. leaf fragment, venation and margin details visible, Nr. 31.4.2.4407i; c. $M$. cf. goeppertii infructescence with 14 attached fruits, Nr. 31.4.2.8103b; d. M. ceriferiformis male catkin, Nr. 31.4.2.5300bi 
been dealt with separately (Zidianakis et al., 2015). In Kassanoi, Myrica lignitum is a dominant element, as it is in Pitsidia. The specimen figured in Pl. 14, fig. 12, with its broad leaf form and prominent secondary veins, may represent another Myrica species, but poor preservation prevents a diagnosis. The examination of the vegetative and reproductive organs of a single Myrica species (Myrica lignitum leaves, $M$. ceriferiformis fruits and $M$. cf. goeppertii male catkins) from Pitsidia suggests a relationship to section Cerophora (sensu Chevalier, 1901) of subgenus Morella and a closer affinity to the American, African and Macaronesian modern species of Myrica than to Eurasian ones (Zidianakis et al., 2015).

\section{Myrica ceriferiformis Kownas}

Fig. 17c

See Zidianakis et al. (2015)

A shoot remain reported as Cupressaceae gen. indet. by Zidianakis et al. (2010) is part of a bare infructescence axis of this taxon.

Myrica cf. goeppertii Kohlman-Adamska, Ziembińska-Tworzydło et Zastawniak

Fig. 17d

See Zidianakis et al. (2015). The inflorescence figured by Kröger (2004: fig. 2.3.4.b, as Carpinus betulus fossilis L.) is a catkin of this taxon.

Family Juglandaceae

Genus Carya Nuttall

$$
\text { Carya sp. - folia }
$$

Pl. 15, figs $1-11$

2010 Carya minor Saporta et Marion; Zidianakis et al., figs 2o, 3c (Pitsidia, central Crete, Tortonian).

2014 Carya serrifolia (Goeppert) Kräusel; Velitzelos D. et al., pl. 27, fig. 5 (Makrilia, E. Crete, Tortonian).

Material. Pitsidia, 20 complete or almost complete leaflets and 43 fragmentary ones (Nrs 31.4.2.206; 31.4.2.471; 31.4.2.971aop,973;

31.4.2.972ai,b; 31.4.2.990a,b;

31.4.2.1232i,1222aop; 31.4.2.1256i;

31.4.2.1684aiii; 31.4.2.1694a,b; 31.4.2.1808;

31.4.2.1920a,b; 31.4.2.2428a,b; 31.4.2.2439a,b;

31.4.2.2656ai,bi; 31.4.2.3359ai,bi; 31.4.2.3520op; 31.4.2.3572ai,bi;

31.4.2.3676,3635opiii; 31.4.2.3827aiv,biv;

31.4.2.3919bop; 31.4.2.3937a,b;

31.4.2.4149ai,bi; 31.4.2.4285; 31.4.2.4321a,b;

31.4.2.4422a,b; 31.4.2.4439ai,bi;

31.4.2.4442a,b; 31.4.2.4704; 31.4.2.4980aopiii;

31.4.2.5068; 31.4.2.5213ai,b; 31.4.2.5224,5551;

31.4.2.5226a,b; 31.4.2.5267aii,b; 31.4.2.5269opi;

31.4.2.5296a,b; 31.4.2.5386a,5385;

31.4.2.5417ai,b; 31.4.2.5447c,5447aii;

31.4.2.5466avii,5466cvi; 31.4.2.5472ai,bi;

31.4.2.5741a,b; 31.4.2.5900ai,bi; 31.4.2.5990a,b;

31.4.2.6192; 31.4.2.6479i,6464op;

31.4.2.6615a,b; 31.4.2.6661a,b; 31.4.2.6714a,b;

31.4.2.6715ii; 31.4.2.6719; 31.4.2.6722;

31.4.2.6949; 31.4.2.6963bbii; 31.4.2.6972;

31.4.2.8010i; 31.4.2.8102; 31.4.2.8212a,b;

31.4.2.8253; 31.4.2.8257i; 31.4.2.8257ii;

31.4.2.8258ai,b; 31.4.2.8259a,b).

Description. Leaflets subsessile (lateral ones) or petiolulate (terminal ones), lamina chartaceous, shape of lateral leaflets elliptic to ovate, shape of terminal ones obovate, 19-71 (average 47.5) $\mathrm{mm}$ long and 11-35 (average 25.5 ) $\mathrm{mm}$ wide, $\mathrm{L} / \mathrm{W}$ ratio $1.4-2.5$ (average 1.9 ), apex acute to acuminate, occasionally characteristically deformed by arthropod feeding, base rounded to widely cuneate, asymmetric in lateral leaflets, symmetric and decurrent in terminal ones; margin sharply simple serrate; teeth dense, fine, \pm irregular in shape, acute, basal side mostly straight, apical side straight to convex or slightly concave, $0.5-1 \mathrm{~mm}$ long, 5-7 teeth per cm, sinuses narrow, angular; primary vein strong, straight to curved or S-like, secondary venation semicraspedodromous to partly craspedodromous, secondaries delicate, almost opposite to alternate, $6-18$ pairs, interspaces $2-7 \mathrm{~mm}$, arising at $50-85^{\circ}$, course curved, slightly irregular, often forked once or more times, sending veinlets into marginal teeth, intersecondaries rare, parallel to secondaries, up to half of the secondary long, tertiary veins dense, percurrent, almost opposite, oblique or almost perpendicular to secondaries, straight to sinuous, quaternary veins forming an irregular square or pentagonal network.

Remarks. The gross morphological traits of these remains clearly suggest an affinity to Carya. Modern foliage of Carya does not show significant differences among the various species (Manchester, 1987). Delimitation of fossil species such as C. minor Saporta et Marion or 


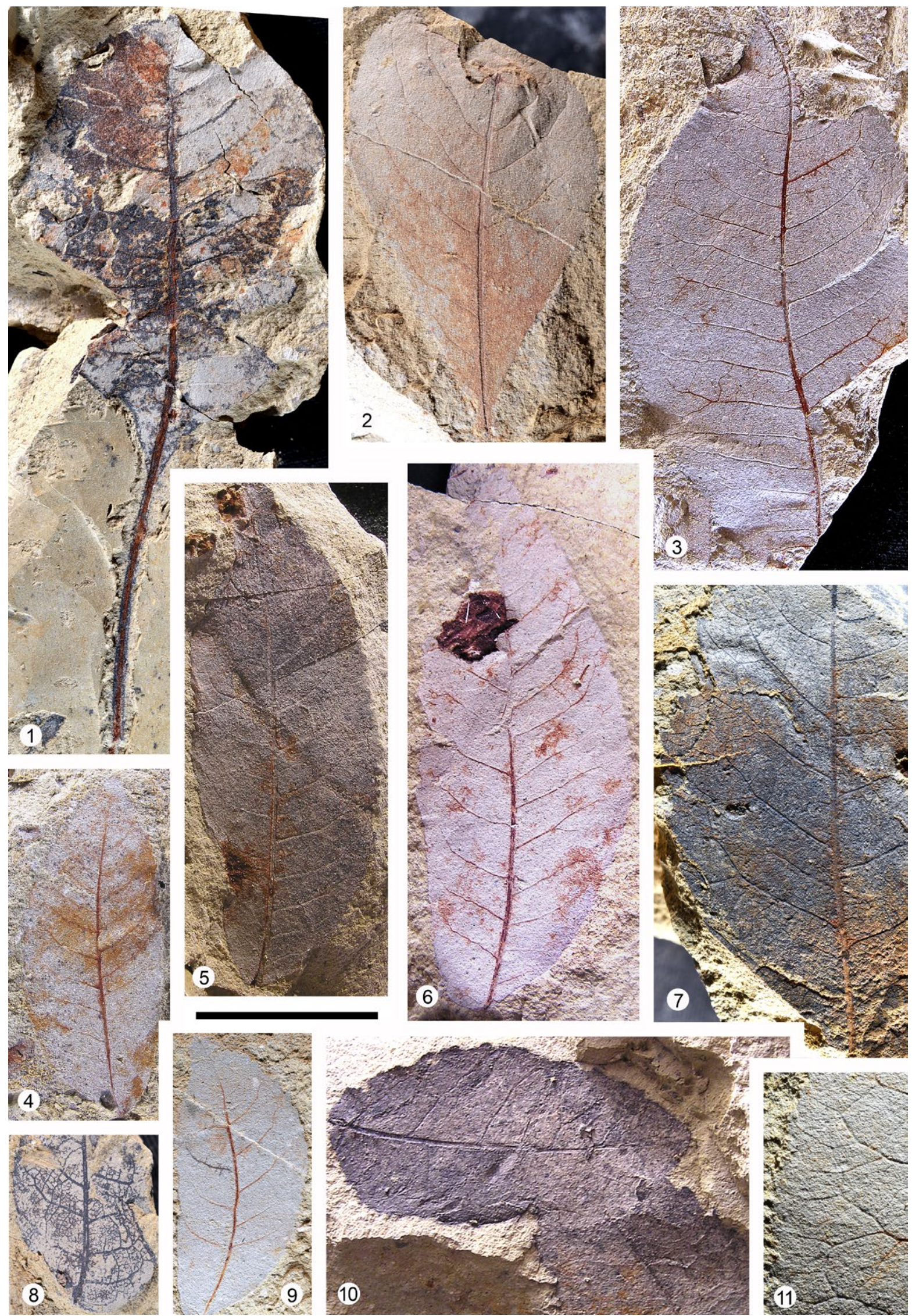

Plate 15. Palaeoflora of Pitsidia, Crete, scale bar $=2 \mathrm{~cm}$ (unless otherwise stated); 1, 2. Carya sp. terminal leaflets; 1 . physically attached on leaf rachis, Nr. 31.4.2.6615a; 2. Nr. 31.4.2.471 (Fig. 3c in Zidianakis et al., 2010); 3-11. Carya sp. lateral leaflets; 3. Nr. 31.4.2.5741a; 4. Nr. 31.4.2.6479i; 5. Nr. 31.4.2.5466cvi; 6. Nr. 31.4.2.206 (Fig. 2o in Zidianakis et al., 2010 ); 7. Nr. 31.4.2.6972; 8. asymmetric lamina base, Nr. 31.4.2.5267b; 9. Nr. 31.4.2.972b; 10. two leaflets, Nr. 31.4.2.8257i; 11. venation pattern close to margin, Nr. 31.4.2.5741a detail, scale bar $=1 \mathrm{~cm}$ 
C. serrifolia (Goeppert) Kräusel is also problematic. Therefore, assignment to a particular fossil species is avoided here. Based on fruits, a few different fossil species have been recognized, for example C. angulata C. Reid et E.M. Reid, C. askenasyi (Kinkelin) Mai and C. globosa (Ludwig) Mädler, suggesting some species diversity in Carya. From Makrilia, Velitzelos D. et al. (2014) figured a fragment of an elongated leaflet as Carya serrifolia, which resembles the slender leaflet forms of Pitsidia both in venation and in marginal teeth. A leaf reported as Quercus drymeja by Zidianakis et al. (2010) actually is a leaflet of this genus.

\section{Genus Pterocarya Kunth}

\section{Pterocarya sp. - fructus}

Pl. 16, fig. 10

Material. Pitsidia, a single fragmentary fruit (Nr. 31.4.2.3000).

Description. Two-winged nutlet, wings oriented parallel to main axis of nutlet, wings broad elliptic, $11 \mathrm{~mm}$ long and $8 \mathrm{~mm}$ wide, margin entire to undulate, with no differential thickenings; wing veins fine, continuous from edge of nutlet to wing margin, bifurcating and occasionally anastomosing; nutlet compressed globose, $3 \mathrm{~mm}$ in diameter, with two remnants of styles diverging from apex.

Remarks. The morphology of this fruit is characteristic of Pterocarya, especially the wing features and the occurrence of style remnants. This is the first report of a fruit of this genus from the fossil record of Greece; foliage of Pterocarya paradisiaca (Unger) Iljinskaya is well represented in the Neogene of continental Greece.

\section{Genus Engelhardia Leschenault ex Blume}

\section{Engelhardia orsbergensis}

(Wessel et Weber) Jähnichen, Mai et Walther

$$
\text { Pl. 16, figs 8, ?9 }
$$

1855 Banksia orsbergensis Wessel et Weber, p. 146, pl. 25, fig. 9a (Orsberg, Germany, late Oligocene).

1977 Engelhardia orsbergensis (Wessel et Weber); Jähnichen et al., p. 326, pls 38-49; text-figs 1-3 (European Tertiary).

1984 Palaeocarya orsbergensis (Wessel et Weber); Jähnichen et al., p. 109, pls 1-6; text-figs 2-4 (European Tertiary).
?1953 cf. Quercus lonchitis Unger; Berger, figs 2, 3 (Kastron, Lemnos Island, early Miocene).

1986b Palaeocarya orsbergensis (Wessel et Weber) Jähnichen, Friedrich, Takáč; Knobloch, Velitzelos, pl. 14, fig. 12 (Prosilio, W. Macedonia, Messinian).

1996 Palaeocarya sp., Sachse, Mohr, pl. 3, fig. 12; pl. 5, figs 2, 7, 8 (Makrilia, E. Crete, Tortonian).

?2002a Engelhardia orsbergensis (Wessel et Weber) Jähnichen, Mai et Walther; Velitzelos et al., p. 12 (Kimi, Euboea, early Miocene) (no figure).

2004 cf. Engelhardia orsbergensis (Wessel et Weber) Jähnichen, Mai et Walther; Sachse, pl. 11, figs 1-4; pl. 19, fig. 12 (Makrilia, E. Crete, Tortonian).

2014 Engelhardia orsbergensis (Wessel et Weber) Jähnichen, Mai et Walther; Velitzelos D. et al., pl. 13, fig. 4 (Lesbos Island, early Miocene).

?2014 Engelhardia orsbergensis (Wessel et Weber) Jähnichen, Mai et Walther; Velitzelos D. et al., p. 66 (Kimi-Nea Stira, Euboea, early Miocene) (no figure).

?2014 Engelhardia orsbergensis (Wessel et Weber) Jähnichen, Mai et Walther; Velitzelos D. et al., p. 69 (Prosilio and Lava, W. Macedonia, Messinian) (no figure).

2015 Engelhardia orsbergensis (Wessel et Weber) Jähnichen, Mai et Walther; Mantzouka et al., figs 5.12-5.13 (Metochia, Gavdos Island, Tortonian).

Material. Metochia, 2 complete leaflets (Nrs 31.5.2.3a,b; 31.5.2.5).

Description. Leaflets shortly petiolulate, petiolule 2 and $6 \mathrm{~mm}$ long; lamina chartaceous, shape lanceolate, asymmetric, 34 and $58 \mathrm{~mm}$ long, 9 and $12 \mathrm{~mm}$ wide, $\mathrm{L} / \mathrm{W}$ ratio 3.7 and 4.8 , base rounded to narrow cuneate, strongly asymmetric in one specimen (Pl. 16, fig. 9), apex acute, margin widely, simply dentate, teeth small, possibly with glands apically, basal side concave to straight, apically concave, sinuses open and shallow; venation camptodromous to semicraspedodromous, primary vein stout, \pm smoothly curved, secondary veins much more delicate, densely spaced, originating at $35-60^{\circ}$, intersecondary veins delicate, parallel to secondaries, higher-order venation not visible.

Remarks. The asymmetric lamina with fine, widely spaced marginal teeth and the venation pattern are characteristic of Engelhardia orsbergensis (Jähnichen et al., 1984). The specimen figured on Pl. 16, fig. 9 shows a rather long petiolule uncharacteristic for $E$. orsbergensis. Its assignment therefore remains somewhat uncertain. In the floras of the Greek peninsula, $E$. orsbergensis was a common element during the early Miocene, whereas in the late Miocene 
it appears mainly in the palaeofloras of Crete. In Makrilia, E. orsbergensis co-occurs with samaras of Engelhardia macroptera (Brongniart) Unger (Sachse, 2004). From Metochia, Mantzouka et al. (2015) described remains of incomplete leaflets.

\section{Juglandaceae gen. et sp. indet. - folia Pl. 16, fig. 7}

Material. Pitsidia: one complete leaflet (Nr. 31.4.2.5901a,b).

De s c r ipti o n. Leaflet possibly sessile, lamina elliptic, $44 \mathrm{~mm}$ long and $15 \mathrm{~mm}$ wide, $\mathrm{L} / \mathrm{W}$ ratio 2.9 , base rounded, apex bluntly acute, entiremargined with one or two pairs of blunt, inconspicuous teeth close to apex; venation brochidodromous to craspedodromous (apically), primary vein almost straight, secondary veins distinct, in $\sim 12$ pairs arising at $45-80^{\circ}$, intervals $3-4 \mathrm{~mm}$, initially straight, then curved, forming well-developed loops close to margin, apically innervating the marginal teeth, tertiary veins percurrent, almost perpendicular to secondaries.

Remarks. This leaf, especially its margin, the course of secondaries and percurrent tertiaries, rather resembles Juglans leaflets.

\section{Family Betulaceae}

\section{Genus Ostrya Scopoli \\ cf. Ostrya sp. - folia}

Pl. 16, figs 11-14, 21; Fig. 15a, d

Material. Pitsidia, 2 almost complete leaves and 5 fragmentary ones (Nrs 31.4.2.1923; 31.4.2.5261; 31.4.2.6206a,b; 31.4.2.6591; 31.4.2.6965a,b; 31.4.2.7036; 31.4.2.8266).

Description. Leaves short petiolate, petiole delicate, up to $5.5 \mathrm{~mm}$ long, lamina chartaceous, narrow elliptic to ovate, $\sim 35-47 \mathrm{~mm}$ long (average $39.5 \mathrm{~mm}$ ) and $11-18 \mathrm{~mm}$ wide (average $14 \mathrm{~mm}$ ), L/W ratio $2.2-3$, base acute, cuneate to convex, symmetric, apex acute to acuminate, not entirely preserved, margin finely simple to weakly double serrate, with narrow, acute teeth and angular sinuses, teeth $\sim 1 \mathrm{~mm}$ long, basal side concave, apical side straight to concave, with acute to acuminate tooth apex; venation craspedodromous, primary vein stout, moderately thick, straight, secondary veins in 12-14 pairs, delicate, densely arranged, interspaces $2.5-4 \mathrm{~mm}$, straight, originating at acute angles of less than $45^{\circ}$, straight to gently curved upwards, forked occasionally at variable distances from margin, forks mostly unequal, innervating the marginal teeth, tertiary veins percurrent, opposite or alternate, very fine, originating almost perpendicularly from secondaries.

R e m a rks. These leaves have a symmetric leaf base, densely spaced seconduries and a finely double serrate margin with delicate teeth. Such leaves often occur in the genus Ostrya.

\section{Family Salicaceae}

Genus Salix L.

Salix angusta A. Braun

Pl. 16, fig. 15

1836 Salix angustifolia A. Braun (in Buckland), p. 512 (Öhningen, Germany, middle Miocene).

1856 Salix angusta A. Braun; Heer, p. 30, pl. 69, figs 1-11 (Swiss Molasse, Switzerland, late Miocene).

?2015 Salix cf. angusta A. Braun; Mantzouka et al., figs 5.7-5.9 (Metochia, Gavdos Island, Tortonian).

M a t e ri a l. Kassanoi, single leaf, almost entire (Nr. 31.6.2.37i).

Description. Leaf lamina linear in shape with parallel margins, $>52 \mathrm{~mm}$ long and $4 \mathrm{~mm}$ wide, L/W ratio 13 , base cuneate, apex attenuate, margin entire to slightly crenulate; venation eucamptodromous, primary vein very strong, slightly bent, secondary veins numerous, $>15$ pairs, delicate, subopposite to alternate, arising at $40-70^{\circ}$, curved upward, forming broad arcs close to margin, intersecondary veins arising at wider angles than secondaries, reaching about half the length of secondaries, tertiary veins indistinct.

Remarks. Examining fossil material from the North Bohemian Basin, Bůžek (1971) combined the entire-margined leaf form, usually described as Salix angusta, with the finely serrate one of Salix lavateri Al. Brown as Salix haidingeri Ettingshausen. He based his viewpoint on the existence of transitional forms between the two extremes, and the lack of differential features. From Gavdos, Mantzouka 

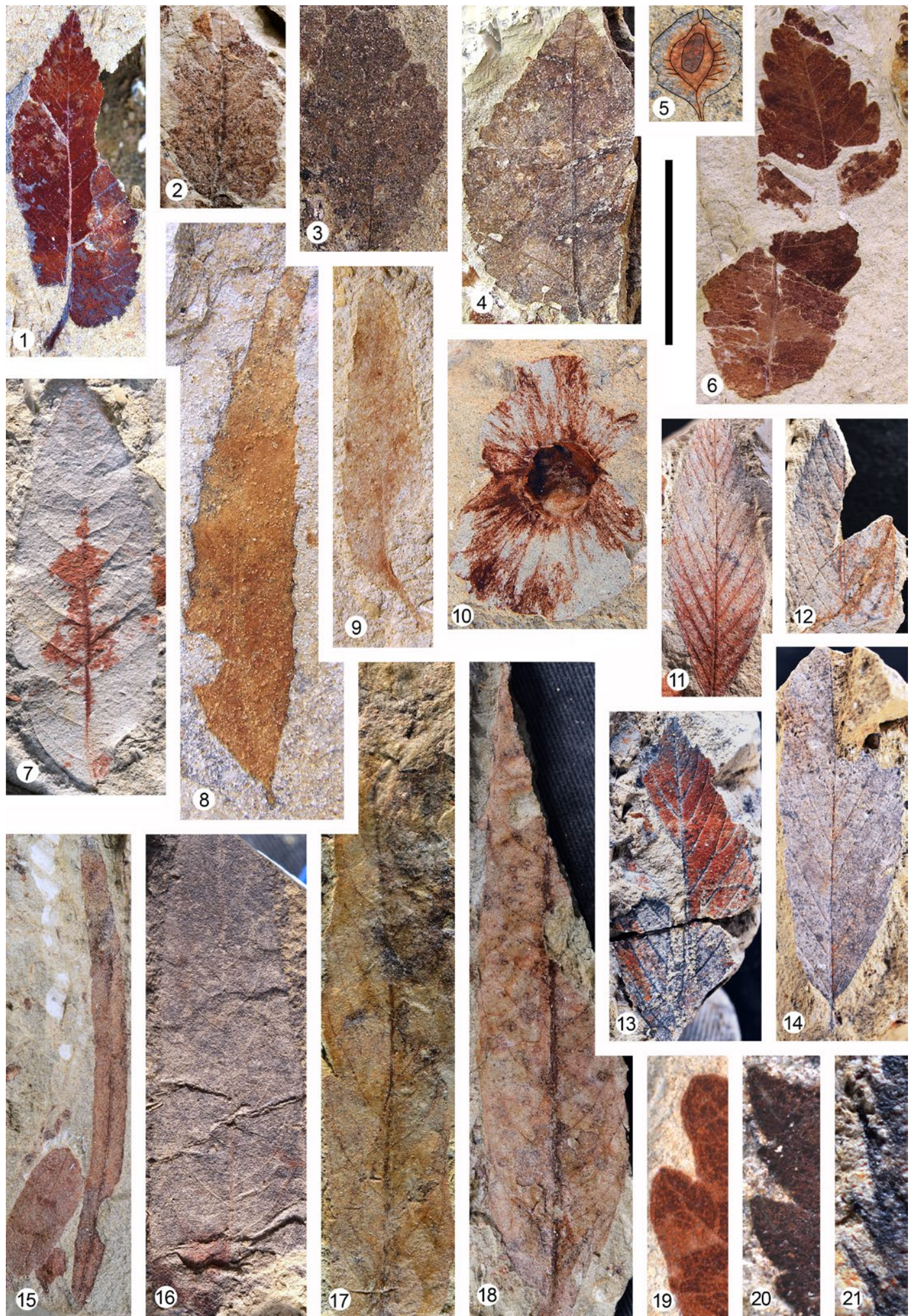

Plate 16. Cretan palaeofloras, scale bar $=2 \mathrm{~cm}$ (unless otherwise stated); 1-4. Ulmus cf. plurinervia Unger, foliage; 1. with strongly asymmetric base, Pitsidia, Nr. 31.4.2.3950ai; 2. Kassanoi, Nr. 31.6.2.119v; 3. Kassanoi, Nr. 31.6.2.79; 4. Kassanoi, Nr. 31.6.2.78a; 5. Ulmus sp., samara, seed, wing margin and preserved venation are lined, Pitsidia, Nr. 31.4.2.4150a, scale bar = $1 \mathrm{~cm}$; 6. ?Zelkova zelkovifolia (Unger) Bůžek et Kotlaba foliage, Pitsidia, Nr. 31.4.2.1663bi; 7. Juglandaceae gen. et sp. indet., leaflet, Pitsidia, Nr. 31.4.2.5901a; 8. Engelhardia orsbergensis (Wessel et Weber) Jähnichen, Mai et Walther, leaflet, Metochia, Nr. 31.5.2.3a; 9. ?Engelhardia orsbergensis (Wessel et Weber) Jähnichen, Mai et Walther, leaflet, Metochia, Nr. 31.5.2.5; 10. Pterocarya sp. winged fruit, Pitsidia, Nr. 31.4.2.3000, scale bar = 7.5 mm; 11-14. cf. Ostrya sp., foliage, Pitsidia; 11. with simple serrate margin, Nr. 31.4.2.8266; 12. with weakly double-serrate margin, Nr. 31.4.2.6206b; 13. Nr. 31.4.2.6591; 14. Nr. 31.4.2.5261; 15. Salix angusta A. Braun, foliage, closely arranged with Podocarpium podocarpum (A. Braun) Herendeen leaflet, Kassanoi, Nr. 31.6.2.37; 16. Salix sp., foliage, Pitsidia, Nr. 31.4.2.1125aiv; 17, 18. ?Salix sp., foliage, Kassanoi; 17. Nr. 31.6.2.49i; 18. Nr. 31.6.2.32; 19-21. leaf margin close-up, Pitsidia; 19. ?Zelkova zelkovifolia (Unger) Bůžek et Kotlaba, simple serrate, Nr. 31.4.2.1663ai detail, scale bar $=4 \mathrm{~mm} ; 2$. Ulmus cf. plurinervia Unger, double serrate, Nr. 31.4.2.3950bi detail, scale bar $=2 \mathrm{~mm}$; 21. cf. Ostrya sp., simple serrate, Nr. 31.4.2.6206b detail, scale bar $=2.5 \mathrm{~mm}$ 
et al. (2015) identified several elongate, entiremargined leaves of willow and assigned them to Salix angusta. These leaves well match the gross morphology of the specimen from Kassanoi. From Makrilia, Sachse (2004) described a number of elongate, entire-margined or probably indistinctly finely serrate leaves under the name Salix type 1 and ?Salix type purpurea. The venation of those specimens (as far as can be recognised) differs from the hereindescribed material by having secondaries that form less broad arcs and equal angles of the secondary and intersecondary veins. Sachse suggested that some of them probably are members of other plant families.

\section{Salix sp. - folia}

Pl. 16, fig. 16

M a te rial. Pitsidia, one fragmentary leaf (Nr. 31.4.2.1125aiv).

Description. Leaf fragment elongate, $\sim 55 \mathrm{~mm}$ long and $18 \mathrm{~mm}$ wide, $\mathrm{L} / \mathrm{W}$ ratio $>3$, base and apex missing, margin finely simple serrate; venation eucamptodromous, midvein moderate, gently curved, secondary veins numerous, rather thin, densely spaced, diverging from midrib at $40-80^{\circ}$, strongly curved along their length, alternating with weak intersecondaries; higher-order venation not visible.

Remarks. This specimen is attributed to Salix based on its laminar shape, the serrate margin, and the secondary as well as intersecondary venation. The determination to species level remains open.

$$
\begin{gathered}
\text { ? Salix sp. - folia } \\
\text { Pl. 16, figs } 17,18
\end{gathered}
$$

Material. Kassanoi: 20 leaves, rather fragmented (Nrs 31.6.2.16iii; 31.6.2.23; 31.6.2.25; 31.6.2.30i; 31.6.2.32; 31.6.2.35i; 31.6.2.43; 31.6.2.44; 31.6.2.45; 31.6.2.49i; 31.6.2.51i; 31.6.2.52i; $31.6 .2 .53 ; \quad 31.6 .2 .57 ; \quad 31.6 .2 .59$; 31.6.2.60;31.6.2.118ii;31.6.2.119vii;31.6.2.120iii; 31.6.2.120vi;).

Description. Leaves petiolate, petiole fragmented, $>5 \mathrm{~mm}$ long, lamina texture chartaceous, shape lanceolate to linear with subparallel margins, 53 to $>95 \mathrm{~mm}$ long, $12-32 \mathrm{~mm}$ wide (widest in lower half of lamina), L/W ratio 5-6, base convex to slightly cuneate, occasionally \pm asymmetric, apex attenuate, margin entire to crenulate; venation eucamptodromous, primary vein very stout, straight or slightly bent, secondary veins numerous, fine, subopposite to alternate, arising at wide angles, mostly $40-70^{\circ}$, interspaces $4-8 \mathrm{~mm}$, course initially straight, then uniformly curved upward, forming broad arcs, intersecondary veins arising at wider angles than secondaries, reaching about half the length of secondaries, tertiary veins invisible.

Remarks. Such leaves are common in the Kassanoi assemblage. They share a few morphological features with Salix but this assignment remains uncertain.

\section{Genus Populus L.}

\section{Populus latior A. Braun}

Pl. 17, figs 1-9

1845 Populus latior A. Braun, p. 169 (Öhningen, Germany, middle Miocene).

1850a Populus latior A. Braun; Unger, p. 416 (Öhningen, Germany, middle Miocene).

1867 Populus attenuata A. Braun; Unger, pl. 6, fig. 29 (Kimi, Euboea, early Miocene).

1994a Populus populina (Brongniart) Knobloch; Kleinhölter, pl. 9, fig. 10; pl. 31, fig. 5 (Pyrgos and Zacharo basins, Peloponnese, Messinian).

1994b Populus populina (Brongniart) Knobloch; Kleinhölter, pl. 2, fig. 5 (Pyrgos and Zacharo basins, Peloponnese, Messinian).

1995 Populus populina (Brongniart) Knobloch; Kleinhölter, pl. 31, figs 6, 7 (Patra, Rion and Corinth basins, Peloponnese, Pliocene).

1999 Populus sp.; Velitzelos, Kvaček, pl. 2, fig. 2 (Vegora, W. Macedonia, Messinian).

2002 Populus populina (Brongniart) Knobloch; Kvaček et al., pl. 21, figs 1-5 (Vegora, W. Macedonia, Messinian).

2007 P. tremula L. foss.; Zidianakis et al., fig. 3D (Vrysses, W. Crete, Messinian).

2010 Populus crenata Berger; Zidianakis et al., fig. 3b (Pitsidia, central Crete, Tortonian).

2014 Populus populina (Brongniart) Knobloch; Velitzelos D. et al., pl. 7, fig. 7 (Grevena, W. Macedonia, early Miocene).

?2014 Populus populina (Brongniart) Knobloch; Velitzelos D. et al., p. 70 (Elassona, Thessaly, Messinian) (no figure).

2015 Populus populina (Brongniart) Knobloch; Mantzouka et al., figs 5.10-5.11 (Metochia, Gavdos Island, Tortonian).

Material. Pitsidia, 5 complete or almost complete leaves and 12 fragmentary ones (Nrs 31.4.2.340a,b; 31.4.2.349a,b; 31.4.2.1140; 31.4.2.1178a,b;31.4.2.1585ai,bi;31.4.2.1940a,b; 

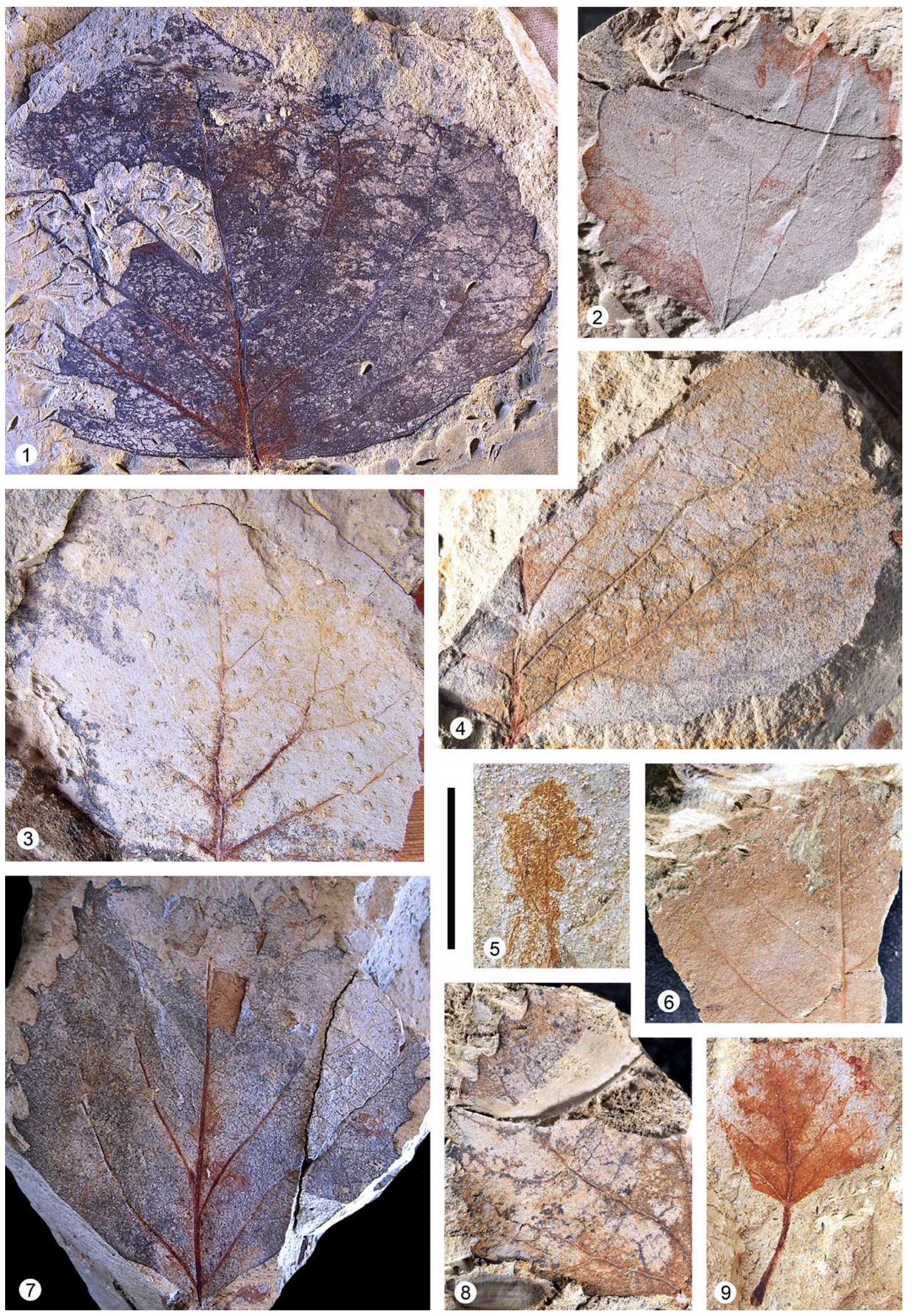

Plate 17. Cretan palaeofloras, scale bar $=2 \mathrm{~cm} ; \mathbf{1 - 9}$. Populus latior A. Braun foliage; 1. typical form, Pitsidia, Nr. 31.4.2.6131a; 2. three-veined form, Pitsidia, Nr. 31.4.2.3027ai; 3. Pitsidia, Nr. 31.4.2.1178b; 4. Pitsidia, Nr. 31.4.2.6948ai; 5. small three-veined leaf, Metochia, Nr. 31.5.2.4; 6. Kassanoi, Nr. 31.6.2.69i; 7. with prominent marginal teeth, Pitsidia, Nr. 31.4.2.349a (Fig. 3b in Zidianakis et al., 2010); 8. with prominent marginal teeth, Pitsidia, Nr. 31.4.2.6111a; 9. small leaf, Pitsidia, Nr. 31.4.2.340b 
31.4.2.2489a,b; 31.4.2.3027ai,b; 31.4.2.3958aii,bii; 31.4.2.4857; 31.4.2.5511aiii; 31.4.2.5933; 31.4.2.6111a,b; 31.4.2.6131a,b; 31.4.2.6934; 31.4.2.6948ai,b; 31.4.2.6999). Kassanoi, 2 fragmentary leaves (Nrs 31.6.2.69i,63; 31.6.2.77). Metochia, one complete leaf (Nr. 31.5.2.4).

Description. Leaves petiolate, petiole up to $63 \mathrm{~mm}$ long; laminar shape ovate to widely elliptic, 20 to $\sim 60 \mathrm{~mm}$ long and 16 to $\sim 80 \mathrm{~mm}$ wide, $\mathrm{L} / \mathrm{W}$ ratio $0.8-1$, base truncate to broadly rounded, apex broadly acute to acuminate, margin coarsely dentate to crenate with blunt, rounded teeth, sometimes glandular at tips, teeth occasionally rather large, acute, sinus rounded; venation semicraspedodromous to basal tri-veined actinodromous (Pl. 17, figs 2, 5), primary vein stout and almost straight, secondary veins in 4-7 pairs, basal pair rather stout, sub- or almost opposite, ascending towards middle part of lamina (in tri-veined specimens towards apex of lamina), secondaries otherwise subopposite to alternate, originating mostly at wide angles of $40-85^{\circ}$, angles decreasing towards apex, interspaces of 4-18 $\mathrm{mm}$, slightly to strongly curved, sending veinlets towards next apical teeth, intersecondaries infrequently present, tertiary veins percurrent, opposite or alternate, sinuous, $3-5$ per $\mathrm{cm}$ of secondary vein, quaternaries forming a polygonal net with further-order venation.

Remarks. The broad ovate shape of the lamina, the broad base and the coarsely dentate margin coincide exactly with the morphology of $P$. populina (Brongniart) Knobloch, which was used until recently and now is considered an illegitimate synonym of Populus latior (Doweld, 2017). The strongly tri-veined leaves (Pl. 17, figs 2,5$)$ well match $P$. populina from Vegora and Rhineland (Belz and Mosbrugger, 1994; Kvaček et al., 2002). In Metochia a similar triveined leaf has been described by Mantzouka et al. (2015: Figs 5.10-5.11 counterparts).

\section{Populus sp. - folia}

Pl. 20, fig. 8

Material. Pitsidia, one almost complete leaf (Nr. 31.4.2.8198i).

Description. Leaf lacking petiole, lamina broadly ovate, $\sim 82 \mathrm{~mm}$ long and $62 \mathrm{~mm}$ wide, base widely rounded, apex not preserved, margin poorly preserved, probably regularly dentate to serrate; venation semicraspedodromous, primary vein strong, almost straight, bent apically, secondary veins thinner, arising at $30-50^{\circ}$, angle decreasing towards apex, interspaced $13-22 \mathrm{~mm}$, course \pm curved, first pair arising at the base somewhat more prominent than the others, tertiary veins percurrent, opposite to alternate, perpendicular to secondaries, straight or slightly sinuous, 7-8 per $\mathrm{cm}$.

Remarks. This leaf differs from the abovedescribed species especially by the laminar shape, angles of secondaries and density of tertiary veins. The poor preservation of the margin prevents an examination of tooth shape and density. The available features match the variation of $P$. balsamoides Goeppert.

\section{Family Lythraceae}

\section{Genus Decodon J.F. Gmelin}

\section{Decodon gibbosus}

(E.M. Reid) E.M. Reid (in Nikitin) - folia

Pl. 20, figs 1-3

?1856 Ficus multinervis Heer, p. 63, pl. 81, figs 6-10; pl. 82, fig. 1 (Swiss Molasse, Switzerland, late Miocene).

?1859 Apocynophyllum helveticum Heer, p. 91, pl. 154, figs 2, 3 (Swiss Molasse, Switzerland, late Miocene).

1920 Diclidocarya gibbosa E.M. Reid, p. 82, pl. 4, figs 23, 25; text-fig. 1 left (Pont de Gail, France, Pliocene).

1929 Decodon gibbosus (E.M. Reid) E.M. Reid in Nikitin, p. 37, pl. 589, figs 8, 9 (Krivoborye, Russia, Pliocene).

1999 Decodon gibbosus (E.M. Reid) E.M. Reid; Kvaček, Sakala, pl. 1, figs 1-8; pl. 2, figs 1-12; pl. 3, figs 1-5; pl. 4, figs 1-6 (Bílina, Czech Republic, early Miocene).

Material. Kassanoi, 2 complete leaves and one fragmentary one (Nrs 31.6.2.35op; 31.6.2.171a,b; 31.6.2.192).

Description. Leaves petiolate, petiole moderately thick, preserved in one specimen, $>7 \mathrm{~mm}$ long; lamina shape ovate to elliptic, symmetric to slightly asymmetric, $\sim 20-55 \mathrm{~mm}$ long and $8.5-24 \mathrm{~mm}$ wide, $\mathrm{L} / \mathrm{W}$ ratio $2.2-2.6$, base cuneate to long cuneate or rounded, apex acuminate, entire-margined to undulate; venation brochidodromous, primary vein strong, straight or gently bent across its length, secondary veins much thinner, numerous, $>15$ pairs, originating at $60-80^{\circ}$, densely arranged, 
interspaces $2-3.5 \mathrm{~mm}$, straight to slightly zigzag, close to margin joining into an intramarginal vein, intersecondary veins $1-2$ per intercostal area, almost parallel to secondaries, reaching about half the length of secondaries, connecting with them and forming elongated, irregularly shaped meshes, only intersecondaries occasionally continuing to intramarginal vein, tertiary veins \pm oblique, interconnecting secondaries and intersecondaries, forming irregular network with higher-order venation.

Remarks. Leaves with this characteristic venation pattern and intramarginal vein are found in several families of modern angiosperms, (e.g. Moraceae, Lythraceae, Rutaceae, Apocynaceae, Asclepiadaceae). Kvaček, Sakala (1999) reported a leafy twig from the early Miocene of the Bilina mine with leaves of similar venation, bearing capsules with intact seeds of Decodon gibbosus (E.M. Reid) E.M. Reid. Some of the detached co-occurring leaves of this species are almost identical to the material from Kassanoi (Kvaček and Sakala, 1999: Pl. 2, figs $9,11)$. The plant fossil assemblages associated with Decodon gibbosus as well as the extant relative Decodon verticillatus (L.) Elliott (from North America) suggest a shallow-water to swampy habitat for this element.

\section{Family Sapindaceae}

\section{Genus Acer L.}

\section{Acer tricuspidatum Bronn}

Pl. 18, figs 1-12; Fig. 18

1838 Acer tricuspidatum Bronn, p. 865, pl. 35, figs $10 \mathrm{a}-\mathrm{b}$ (Salzhausen, Germany, middle Miocene).

1867 Acer trilobatum A. Braun; Unger, pl. 12, figs 28-29 (Kimi, Euboea, early Miocene).

1953 Acer trilobatum A. Braun; Berger, fig. 12 (Kastron, Lemnos Island, early Miocene).

1953 Acer (Palaeo-Spicata) ponzianum Gaudin; Berger, figs 24-26 (Allatini, Central Macedonia, Pliocene).

1981 Acer platyphyllum A. Braun; Velitzelos, Petrescu, pl. 3, fig. 3 (Vegora, W. Macedonia, Messinian).

?1985 Acer tricuspidatum Bronn; Dermitzakis et al., p. 165 (Kato Komi, Chios Island, SerravallianTortonian) (no figure).

1986a Acer tricuspidatum Bronn; Knobloch, Velitzelos, pl. 5, fig. 9 (Elassona, Thessaly, Messinian).

1986b Acer cf. tricuspidatum Bronn; Knobloch, Velitzelos, pl. 14, figs 1, 7 (Prosilio, W. Macedonia, Messinian).
?1987 Acer tricuspidatum Bronn; Knobloch, Velitzelos p. 160 (Lava, W. Macedonia, Messinian) (no figure).

?1993 Acer tricuspidatum Bronn; Velitzelos, p. 7 (Iliokomi-Kormitsa, E. Macedonia, Messinian) (no figure).

1994a Acer tricuspidatum Bronn; Kleinhölter, pl. 7, fig. 1; pl. 8, fig. 1; pl. 29 figs 6-8 (Pyrgos and Zacharo basins, Peloponnese, Messinian).

1999 Acer tricuspidatum Bronn; Velitzelos et al., fig. F3 in p. 461(Kastron, Lemnos Island, early Miocene).

2002 Acer tricuspidatum Bronn; Kvaček et al., pl. 23, figs 1-3, 6, 7; pl. 32, fig. 6 (Vegora, W. Macedonia, Messinian).

2014 Acer tricuspidatum Bronn; Velitzelos D. et al., pl. 7, fig. 10 (Grevena, W. Macedonia, early Miocene).

2014 Acer tricuspidatum Bronn; Velitzelos D. et al., pl. 18, figs 13, 14 (Prosilio, W. Macedonia, Messinian).

?2014 Acer tricuspidatum Bronn, Velitzelos D. et al., p. 70 (Paghi, Corfu Island, Messinian) (no figure).

2014 Acer tricuspidatum Bronn, Velitzelos D. et al., pl. 26, fig. 3 (Kato Komi, Chios Island, Serravallian-Tortonian).

?2014 Acer tricuspidatum Bronn, Velitzelos D. et al., p. 77 (Makrision, Peloponnese, Pliocene) (no figure).

Material. Pitsidia, 6 complete or almost complete leaves and 13 fragmentary ones (Nrs 31.4.2.853ai,bi; 31.4.2.998a,b; 31.4.2.1932a,b;

31.4.2.2139a,b; 31.4.2.2437a,b;

31.4.2.3496a,bi; 31.4.2.3985i; 31.4.2.4099;

31.4.2.4129; 31.4.2.4251ii; 31.4.2.4345ai,b;

?31.4.2.4361; 31.4.2.5112ai,b; 31.4.2.6327ii;

31.4.2.6922ai,b; 31.4.2.8195; 31.4.2.8203;

31.4.2.8247; 31.4.2.8262i).

Description. Leaves lacking petiole, lamina chartaceous, shape trilobate to simple tricuspidate, $\sim 21-65 \mathrm{~mm}$ long and $13-80 \mathrm{~mm}$ wide, L/W 0.8-1.7, base rounded to subcordate, lobe apices acute to acuminate, margin simple serrate, tooth size variable, teeth blunt (mostly in basal part of lamina) to sharp (mainly in apical part of lamina), basal side mostly concave, convex or flexuous, rarely straight, apical side straight, retroflexed or occasionally convex, 3-5 teeth per $\mathrm{cm}$, or less near lamina base, sinuses between lobes shallow and wide, \pm angular, lobes widely triangular, medial lobe 10-21 mm long and 20-35 mm wide, lateral lobes shorter and narrower; venation basal actinodromous with 3 main veins, moderately thick and strong, straight or slightly bent, diverging at $35-45^{\circ}$ in unlobed (tricuspidate) and at $32-65^{\circ}$ in three-lobed leaves, secondary 

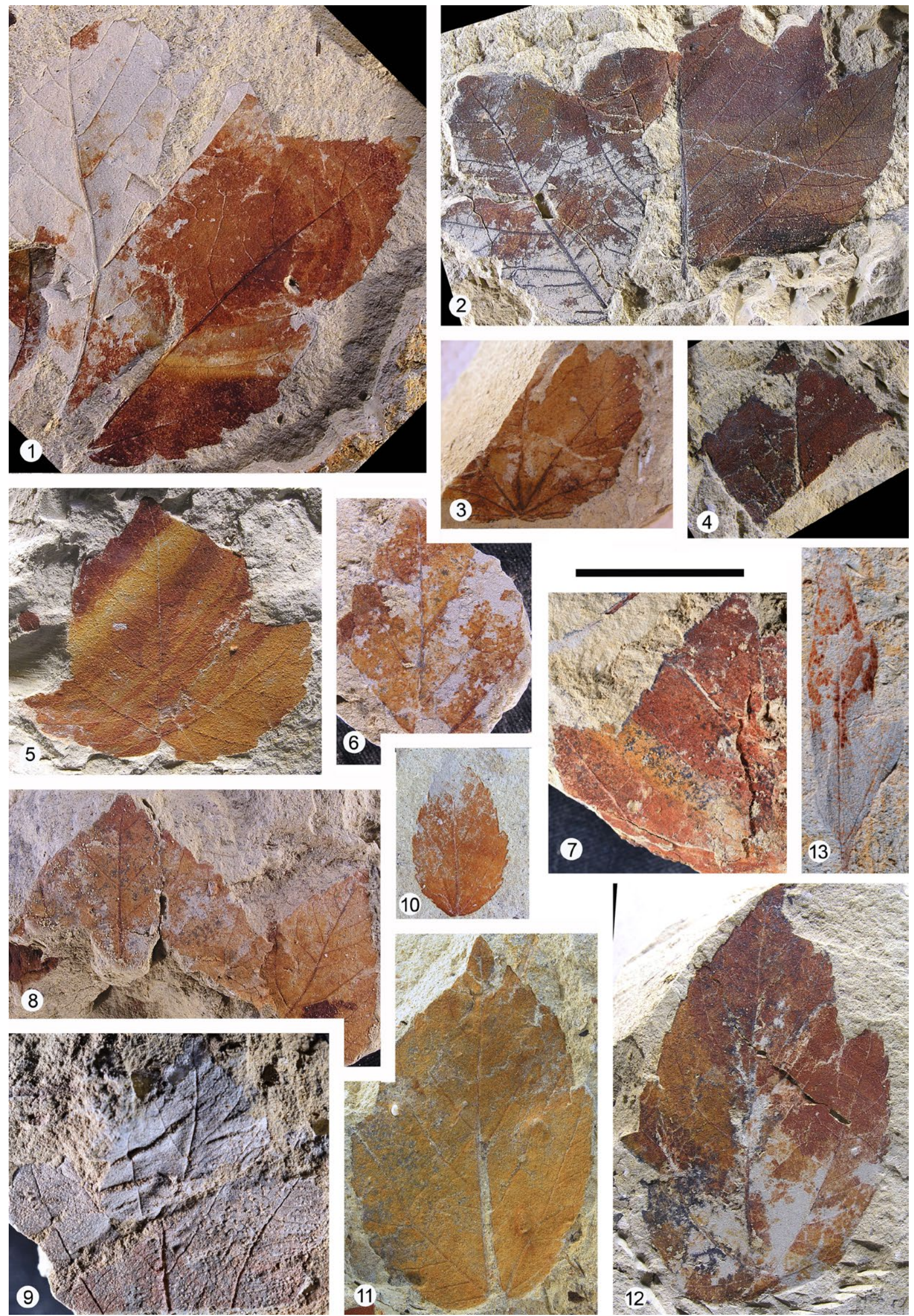

Plate 18. Palaeoflora of Pitsidia, scale bar $=2 \mathrm{~cm}$ (unless otherwise stated); 1-9. Acer tricuspidatum Bronn, foliage, lobed form; 1. Nr. 31.4.2.4345ai; 2. Nr. 31.4.2.853bi; 3. Nr. 31.4.2.998a; 4. Nr. 31.4.2.4099; 5. Nr. 31.4.2.6922ai; 6. Nr. 31.4.2.4361; 7. Nr. 31.4.2.4129; 8. Nr. 31.4.2.2437a; 9. Nr. 31.4.2.8247; 10-12. Acer tricuspidatum Bronn, foliage, tricuspidate form; 10. small leaf, Nr. 31.4.2.8262i; 11. Nr. 31.4.2.3496bi; 12. Nr. 31.4.2.5112ai; 13. ?Acer aegopodifolium (Goeppert) Bajkovskaya ex Iljinskaya, leaflet, Nr. 31.4.2.5697bii, scale bar $=1 \mathrm{~cm}$ 

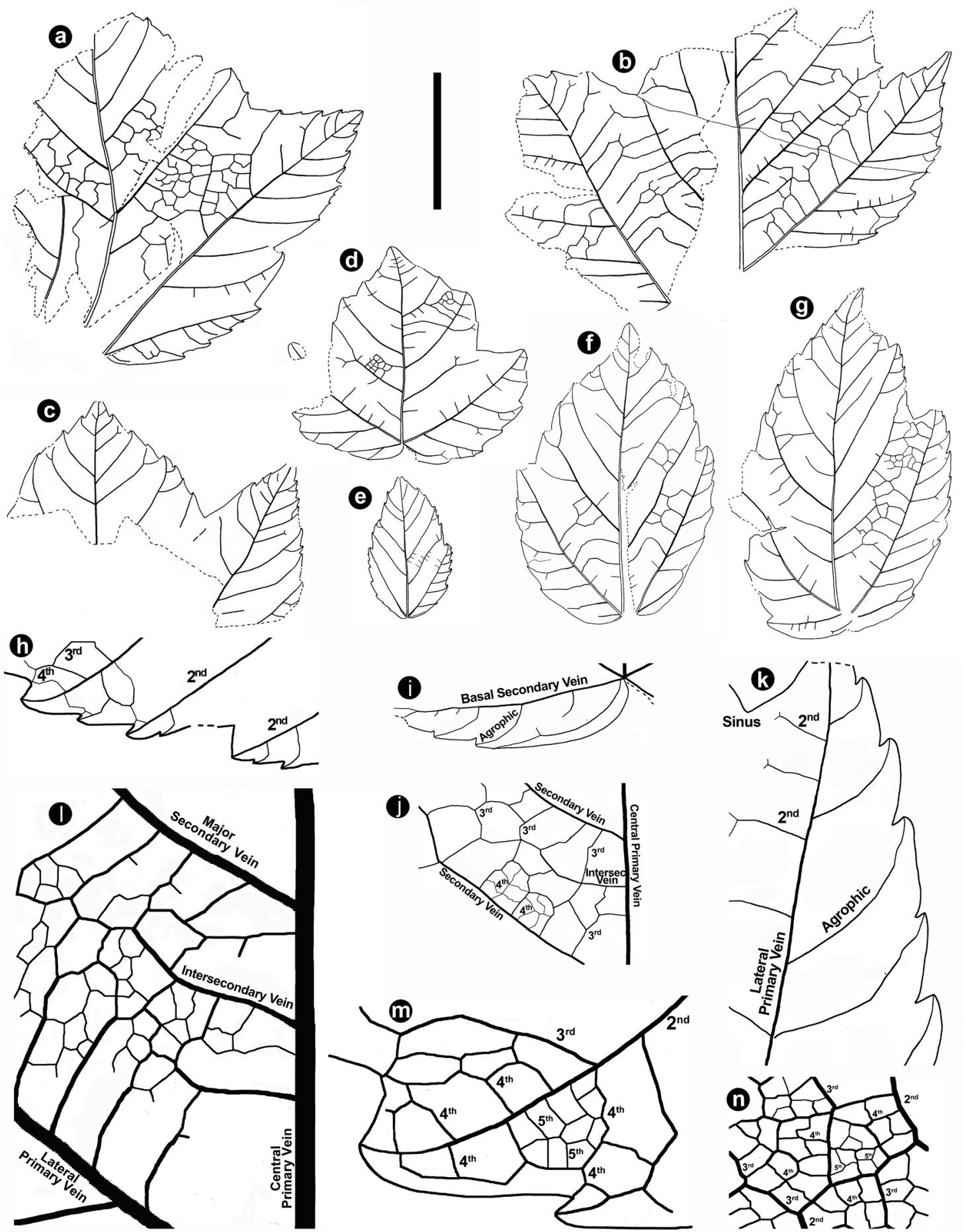

Fig. 18. Palaeoflora of Pitsidia. Acer tricuspidatum, foliage, line drawings, scale bar $=2 \mathrm{~cm}$ (unless otherwise stated); a-d with lobed lamina; a. Nr. 31.4.2.4345ai; b. Nr. 31.4.2.853bi; c. Nr. 31.4.2.2437a; d. Nr. 31.4.2.6922ai; e-g. with tricuspidate lamina; e. Nr. 31.4.2.8262i; f. Nr. 31.4.2.3496bi; g. Nr. 31.4.2.5112ai; h-k. margin and venation details, scale bar = $5 \mathrm{~mm}$; h. Nr. 31.4.2.853ai detail; i. Nr. 31.4.2.6922ai detail; j. Nr. 31.4.2.6922ai detail; k. Nr. 31.4.2.5112ai detail; l-n. margin and venation details, scale bar $=1.25 \mathrm{~mm}$; . Nr. 31.4.2.853ai detail; $\mathbf{m}$. Nr. 31.4.2.853ai detail; $\mathbf{n}$. Nr. 31.4.2.5112ai detail

veins mostly craspedodromous, in 6-9 pairs, position alternate or subopposite, originating at $30-70^{\circ}$, usually irregularly spaced, curved or rarely straight, intersecondary veins absent or one per intercostal area, usually not well developed, less than half the length of secondary, \pm parallel to secondaries, forked; agrophic veins in basal part of lamina well developed,
5-7 on each side of lamina, tertiary veins very fine, reticulate or very weakly alternate percurrent, $\sim 5-6$ per $\mathrm{cm}$ of secondary, arising at $\sim 90^{\circ}$, forming \pm irregular polygonal network; $4^{\text {th }}$ - and $5^{\text {th }}$-order veins \pm reticulate, forming polygons in the former and mostly pentagons in the latter; tooth principal vein terminating in tooth apex, course of accessory tooth veins convex. 
Remarks. The material of Pitsidia shows remarkable variability, ranging from broad trilobate forms to small, narrow, simple, tricuspidate leaves. This variation well matches A. tricuspidatum, a widespread floristic element during the late Oligocene and Neogene across Central Europe (Kovar-Eder et al., 1994). Because of its morphological variability, A. tricuspidatum has been ascribed several forms or subspecies (e.g. Procházka and Bůžek, 1975; Hummel, 1983; Ströbitzer-Hermann, 2002), mostly related to swampy and riparian habitats. Among them, A. tricuspidatum forma pyrenaicum Rérolle sensu Ströbitzer-Hermann is closer to the Pitsidia material.

\section{Acer integrilobum Weber sensu Walther}

\section{Pl. 19, figs 1-7; Fig. 19}

1852 Acer integrilobum Weber, p. 196, pl. 22, figs 5a-b (Rott, Germany, Oligocene).

1972 Acer integrilobum Weber; Walther, p. 111, pl. 25, figs 1-7, 9, ?10; pl. 26, figs 1, 2, 4-7, ?8, 9, 10; pl. 56, figs 6, 7 (European Tertiary).

1986b Acer integrilobum Weber; Knobloch, Velitzelos, pl. 14, fig. 5 (Prosilio, W. Macedonia, Messinian).

1994b Acer integrilobum Weber, Kleinhölter, pl. 31, fig. 2 (Pyrgos and Zacharo basins, Peloponnese, Messinian).

1996 Acer decipiens A. Braun, Sachse, Mohr, pl. 3, figs ?38, 39; pl. 7, fig. 7 (Makrilia, E. Crete, Tortonian).

2002 Acer integrilobum Weber; Kvaček et al., pl. 25, figs 3-5, 7 (Vegora, W. Macedonia, Messinian).

2004 Acer ser. Monspessulana Pojark; Sachse, pl. 8, figs 12, ?13, 14; pl. 20, figs ?2, 3 (Makrilia, E. Crete, Tortonian).

2007 Acer pseudomonspessulanum Unger; Zidianakis et al., figs 3I-L, 5L, P, R (Vrysses, W. Crete, Messinian).

2010 Acer pseudomonspessulanum Unger; Zidianakis et al., fig. 3k (Pitsidia, central Crete, Tortonian).

Material. Pitsidia, 6 complete and 3 fragmentary leaves (Nrs 31.4.2.211a,b; 31.4.2.851a,bi; 31.4.2.1030ai,b; 31.4.2.2581ai,b; 31.4.2.3627aop,3610; $\quad 31.4 .2 .4537 \mathrm{ai}, \mathrm{b}$; 31.4.2.5464ai,c; 31.4.2.5494a,b; 31.4.2.6103ai,b).

Description. Palmately three-lobed leaves lacking petiole, lamina chartaceous, shape broad ovate, 23-48 (average 34) $\mathrm{mm}$ long and 26-54 (average 42) $\mathrm{mm}$ wide, lamina $\mathrm{L} / \mathrm{W}$ ratio $0.8-1$ (average 0.9 ), base subcordate to rounded, margin entire, central lobe more prominent, abruptly narrowing, longer than lateral ones, lobe apices mostly acute, tip rounded, sinuses between lobes usually rounded and wide; venation basal actinodromous with three moderately strong primary veins, often bent apically, angles between central primary and lateral veins $40-70^{\circ}$ (average $57^{\circ}$ ), secondary veins slender, brochidodromous, originating at $45-90^{\circ}$ (average $65^{\circ}$ ) from primaries, \pm straight, looping with adjacent ones close to margin, intersecondary veins frequent in central lobe, very fine, tertiary veins random reticulate or very weakly alternate percurrent, forming \pm irregular polygonal net with $4^{\text {th }}$ - and $5^{\text {th }}$-order venation.

Rem arks. This material differs from A. pseudomonspessulanum Unger by the longer and broader, abruptly narrowing central lobe, wide and rounded sinuses, and lateral lobes narrowing continuously. Acer integrilobum usually constitutes an accessory element in mesophytic forests of the European Paleogene/Neogene. In Crete, A. integrilobum is represented by several specimens, not only in Pitsidia but also in Makrilia and Vrysses (Sachse, 2004; Zidianakis et al., 2007).

\section{?Acer aegopodifolium}

(Goeppert) Bajkovskaya ex Iljinskaya

Pl. 18, fig. 13

?1855 Rhus aegopodifolia Goeppert, p. 37, pl. 25, fig. 10 (Sośnica, Poland, late Miocene).

?1968 Acer aegopodifolium (Goeppert) BajkovskayaIljinskaya, p. 67, pl. 9, figs 12-15; pl. 20, figs 5, 6 (Rika, Ignatovskoe, Russia, Neogene).

Material. Pitsidia, a single complete leaflet (Nr. 31.4.2.5697aii,bii).

Description. Lamina texture probably chartaceous, shape asymmetrically lanceolate, $20 \mathrm{~mm}$ long and $6 \mathrm{~mm}$ wide, $\mathrm{L} / \mathrm{W}$ ratio 3.3 , base narrow cuneate, apex acute, margin probably entire on one side, two teeth on the other; teeth prominent with acute apices, sinuses rounded; venation suprabasal actinodromous with two primary veins, central primary vein stout, smoothly curved near apex, lateral primary vein very similar to central one, entering rather large lower marginal tooth; secondary veins on toothed side craspedodromous to camptodromous, 3-4 in number, originating at $35-50^{\circ}$, curved, on entire-margined side indistinct, camptodromous, higher-order venation reticulate, forming irregular network.

Remarks. This sample possibly is a lateral leaflet of $A$. aegopodifolium. However, its identification should remain open because it is 

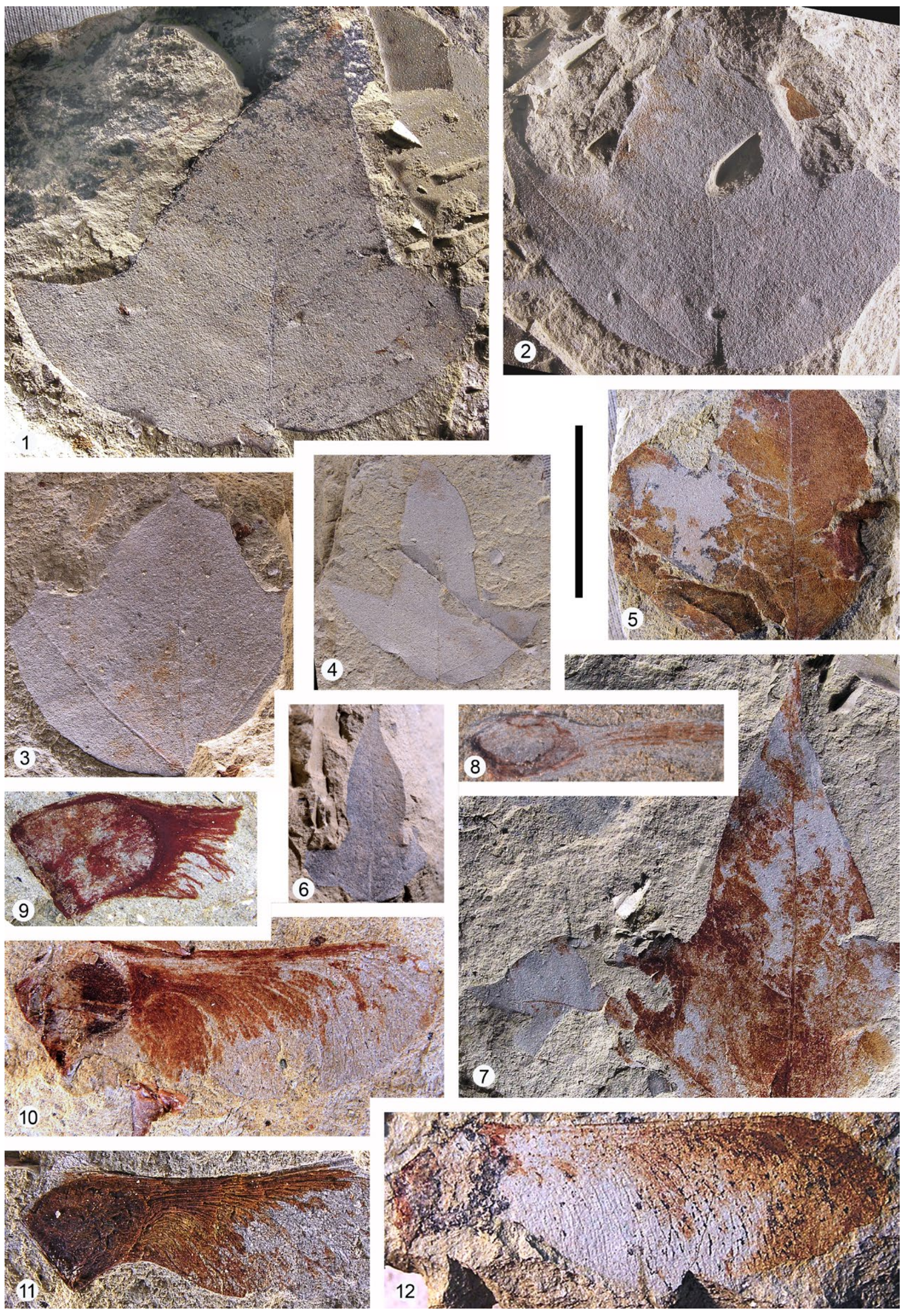

Plate 19. Palaeoflora of Pitsidia; 1-7. Acer integrilobum Weber sensu Walther, foliage, scale bar = $2 \mathrm{~cm}$; 1. Nr. 31.4.2.6103ai; 2. Nr. 31.4.2.5464ai; 3. Nr. 31.4.2.211b; 4. small leaf, Nr. 31.4.2.1030b; 5. Nr. 31.4.2.851a; 6. small leaf, Nr. 31.4.2.3627aop; 7. Nr. 31.4.2.4537ai; 8. Acer sp. 2, winged fruit, Nr. 31.4.2.1653b, scale bar = $1 \mathrm{~cm} ; \mathbf{9 - 1 2}$. Acer $\mathrm{sp}$. 1, winged fruits, scale bar $=1$ cm; 9. Nr. 31.4.2.4390a; 10. Nr. 31.4.2.3949ai; 11. Nr. 31.4.2.5545a; 12. Nr. 31.4.2.8263 


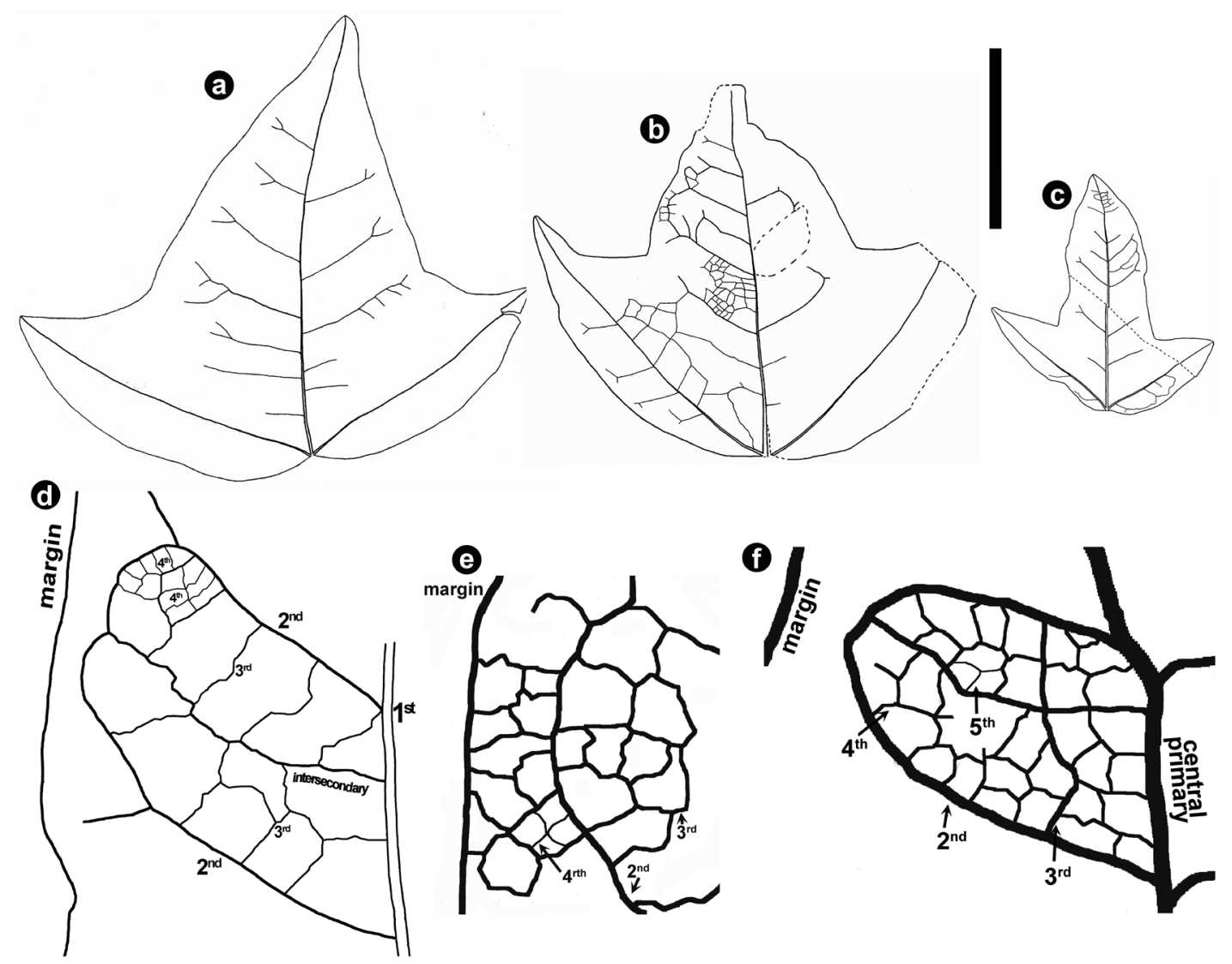

Fig. 19. Palaeoflora of Pitsidia. Acer integrilobum foliage, line drawings, scale bar $=2 \mathrm{~cm}$ (unless otherwise stated); a. complete leaf, Nr. 31.4.2.6103ai; b. almost complete leaf, Nr. 31.4.2.5464ai; c. small leaf, Nr. 31.4.2.1030b; d-f. venation pattern details of central lobe; $\mathbf{d}$. Nr. 31.4.2.1030ai detail, scale bar = 2.5 mm; e. Nr. 31.4.2.1030ai detail, scale bar = $0.75 \mathrm{~mm}$; f. close to lobe apex, Nr. 31.4.2.1030b detail, scale bar $=0.75 \mathrm{~mm}$

difficult to clarify whether the entire margin on the left side represents the original leaf shape or is a taphonomic distortion. References to this species from the Greek Neogene are very rare: only one specimen from Vegora has been reported (Velitzelos and Kvaček, 1999).

\section{Acer sp. 1 - fructus}

Pl. 19, figs 9-12; Fig. 20

Material. Pitsidia, 2 complete and 4 fragmentary samaras (Nrs 31.4.2.3949ai,bi; 31.4.2.4289; 31.4.2.4390a,b; 31.4.2.4453a,b; 31.4.2.5545a,b; 31.4.2.8263)

Description (for terminology see Fig. 20). Winged fruits, $25-31 \mathrm{~mm}$ long, nutlet flat, broad elliptic to oval, 6-9 $\mathrm{mm}$ long and 4-6 mm wide, contact line of nutlet $5-7 \mathrm{~mm}$ long; angle between proximal margin of wing and contact line of nutlet (attachment angle) $50-58^{\circ}$; wing $18-24 \mathrm{~mm}$ long and $8-10 \mathrm{~mm}$ wide, proximal side of wing gently concave, distal one distinctly convex, wing apex widely obtuse to rounded, wing broadest in its middle part, gradually narrowing towards point of attachment and frequently clasping less than $1 / 3$ of nutlet, veins numerous, distinct, curved, dichotomised more than twice.

Remarks. Sachse (2004) reported from Makrilia three different winged fruit types of Acer. The Makrilia specimen referred to Acer sp. type 3 (Sachse, 2004: Pl. 17, fig. 3) shows similarities with the herein described fruits based on wing shape and size as well as nutlet attachment angle.

Acer sp. 2 - fructus

Pl. 19, fig. 8; Fig. 20

Material. Pitsidia: two incomplete samaras (Nrs 31.4.2.1653a,b; 31.4.2.8080).

Description. Fruit winged, $>21 \mathrm{~mm}$ long; nutlet elliptic, 6-8 $\mathrm{mm}$ long and 3-4 mm wide, contact line of nutlet $\sim 3 \mathrm{~mm}$ long; attachment angle $\sim 40-45^{\circ}$; wing partly preserved, rather narrow especially close to nutlet, the preserved part $4 \mathrm{~mm}$ wide, proximal side of wing S-like, distal side concave, wing apex not preserved; wing veins numerous. 


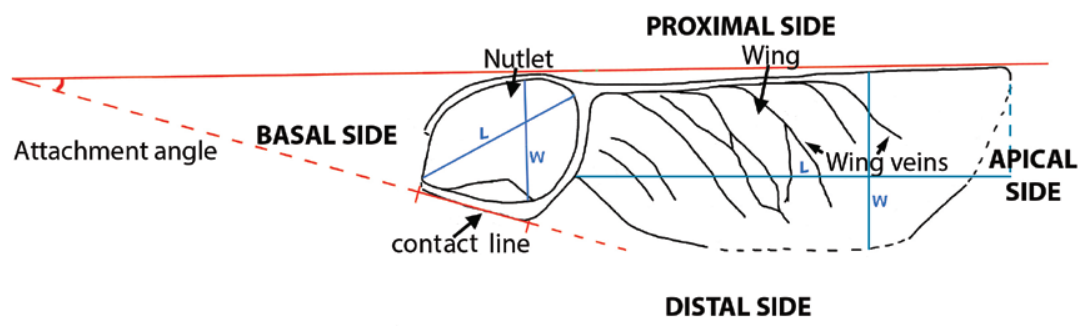

Fig. 20. Terminology of winged fruits of Acer (from Wolfe and Tanai, 1987)

Re m a rks. Acer sp. 2 differs from Acer sp. 1 by the shape of the nutlet, the short wing attachment, and wing shape. These two types of samaras probably belong to the maple species described above on the basis of leaves.

\section{Family Oleaceae}

\section{Genus Fraxinus L.}

Fraxinus sp. - folia

Pl. 20, figs $4-7$

?1994a Fraxinus ungeri (Gaudin) Knobloch et Kvaček - Kleinhölter, pl. 32, figs 6, 7 (Patra, Rion and Corinth basins, Peloponnese, Pliocene)

Material. Kassanoi, a complete leaflet and two fragmentary ones (Nrs 31.6.2.18aii,bii; 31.6.2.159a,b; 31.6.2.160).

Description. Leaflets petiolulate, petiolule strong, > $2 \mathrm{~mm}$ long; lamina probably chartaceous, elongate oblong to lanceolate or falcate, 62 to $>75 \mathrm{~mm}$ long and 17-26 $\mathrm{mm}$ wide, $\mathrm{L} / \mathrm{W}$ ratio $3.2-3.5$, base cuneate, strongly asymmetric, apex widely acute to acuminate, margin coarsely serrate to crenulate, teeth small, blunt, irregularly spaced, 1.5-2.5 per $\mathrm{cm}$, sinuses shallow, rounded; venation semicraspedodromous, midrib strong, proximally \pm bent, $\sim 12$ pairs of thin secondary veins, arising at $50-70^{\circ}$, initially straight, close to margin bent, forked, one branch forming weak loops with supradjacent secondary, the other giving rise to veinlets, reaching marginal sinuses, intersecondary veins occasionally present, half the length of and parallel to secondaries, tertiary veins reticulate, forming irregular network with higher-order venation.

Remarks. Based on the laminar shape and the secondary and tertiary venation pattern, these remains resemble leaflets of Fraxinus. Contrary to Juglandaceae, in which the tertiary venation is mainly percurrent, in Fraxinus it is reticulate. Reports of ash leaflets are generally not common, possibly because shed ash foliage rapidly decays. The cuticle preservation, which enables distinction from Juglandaceae, is even rarer (Kovar-Eder and Krainer, 1991). The only records from the Greek region derive from the Pliocene basins of Patra, Rio and Corinth in the North Peloponnese (Kleinhölter, 1994a). Unlike foliage, ash fruits are rather common, probably due to their robustness. Although several fossil species have been established, gross morphology is not sufficient for an assignment to species level (Kovar-Eder et al., 2004). Fruits of ash have also been reported from various Greek Neogene localities such as Makrilia, Vegora, Prosilio, Likoudi (late Miocene) and N. Peloponnese (Pliocene) (Kleinhölter, 1994a; Sachse, 2004; Velitzelos D. et al., 2014).

Angiospermae incertae sedis

\section{Monocotyledonae}

Apart from the below-described specimens (Monocotylophyllum sp. 1-10), at least 68 leaf fragments from Pitsidia and 38 from Kassanoi with parallel primary veins are available. All of them are of monocotyledonous affinity. Their identification is biased, however, by poor preservation and a lack of diagnostic features. These monocotyledons probably represent hydrophilic grass-like herbs or reeds and sedges.

\section{Genus Monocotylophyllum E.M. Reid et Chandler}

\section{Monocotylophyllum sp. 1}

\author{
Pl. 22, figs 1, 2, 17
}

Material. Pitsidia, 3 incomplete leaves (in groups) and 15 isolated leaf fragments (Nrs 31.4.2.907i; 31.4.2.1182ai,b; 31.4.2.1576ai,b; 31.4.2.1576aii; 31.4.2.1588i; 31.4.2.1595a,bi; 31.4.2.1748a,b; 31.4.2.2313a,b; 31.4.2.2315a,b; 31.4.2.2368a,b; 31.4.2.2425a,b; 31.4.2.4334a-d; 

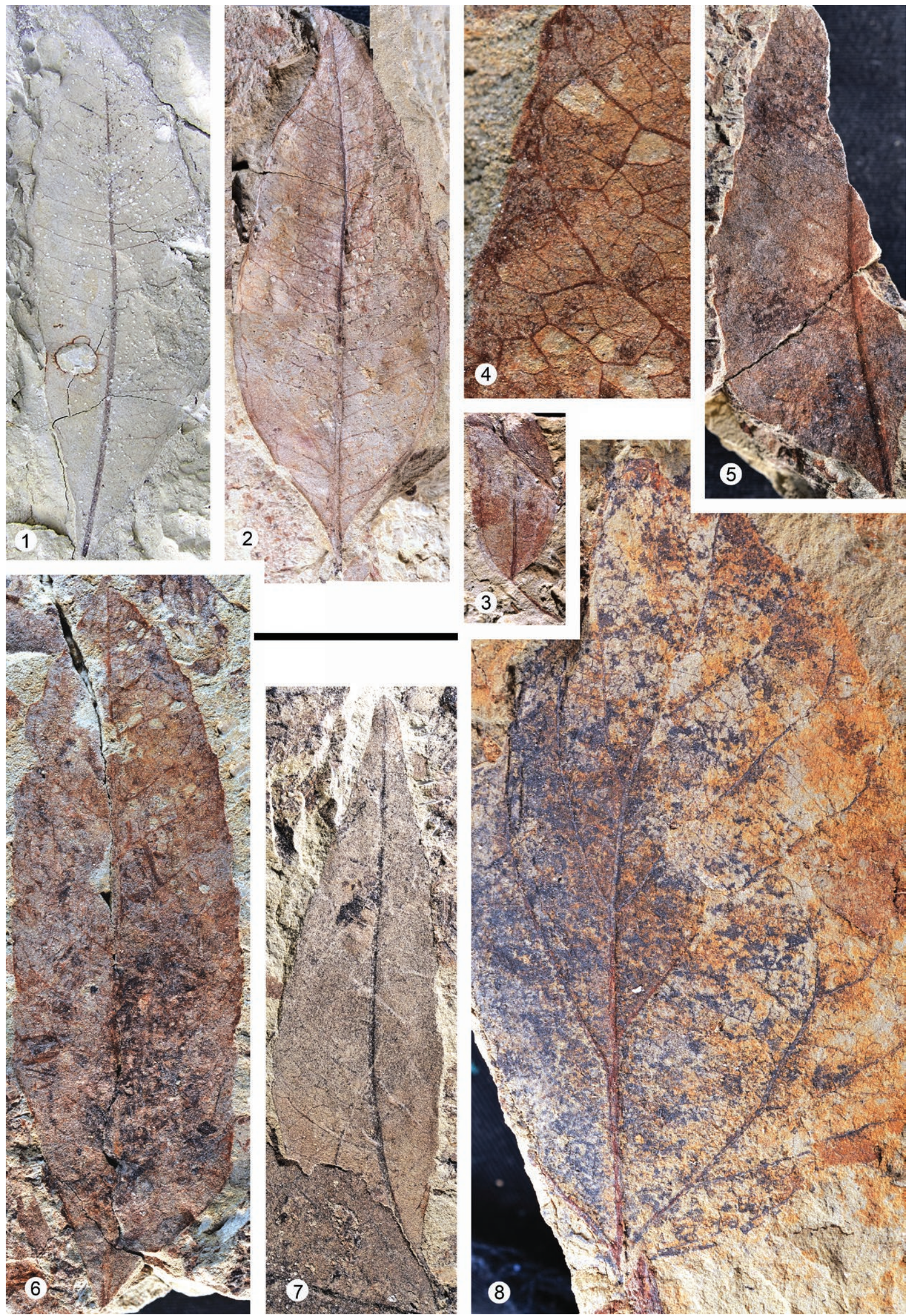

Plate 20. Cretan palaeofloras, scale bar $=2 \mathrm{~cm}$ (unless otherwise stated); 1-3. Decodon gibbosus (E.M. Reid) E.M. Reid, foliage, Kassanoi; 1. Nr. 31.6.2.35op; 2. synthesis of counterparts, Nr. 31.6.2.171a,b; 3. small leaf, Nr. 31.6.2.192; 4-7. Fraxinus sp., leaflets, Kassanoi; 4. venation pattern, close-up, Nr. 31.6.2. 159b detail, scale bar = $7.5 \mathrm{~mm}$; 5. Nr. 31.6.2.160; 6. Nr. 31.6.2.159a; 7. Nr. 31.6.2.18aii; 8. Populus sp., foliage, Pitsidia; Nr. 31.4.2.8198i 
31.4.2.4359; 31.4.2.4959a,b; 31.4.2.5571a,b; 31.4.2.6321; 31.4.2.6576; 31.4.2.8082).

Description. Fragmentary leaves, single or in groups of 2-3, connected at base, linear in shape, $>80 \mathrm{~mm}$ long and 5-12 $\mathrm{mm}$ wide, entire-margined with numerous, often hardly visible, parallel primary veins of similar thickness interspaced $\sim 0.2 \mathrm{~mm}$, higher-order venation not visible; leaves frequently mechanically damaged, forming a group of strings and belts. Occasionally, coarse sand is accumulated at the basal part where the leaves are fused (Pl. 22, figs 2, 17).

Remarks. The preservation of organically connected leaves implies that this monocot thrived in or very close to the waterbody where it was embedded. Coarse sand grains apparently were trapped at the base of these herbaceous plants.

\section{Monocotylophyllum sp. 2}

Pl. 21, figs 10, 11; Fig. 21

Material. Pitsidia, 16 leaf fragments (Nrs 31.4.2.1017bop; 31.4.2.1452; 31.4.2.2872op; 31.4.2.3027aiii; 31.4.2.3198op; 31.4.2.3939; 31.4.2.3940; 31.4.2.4750i; 31.4.2.4774; 31.4.2.4955; 1.4.2.5949iii; 31.4.2.5981opi; 31.4.2.6051biii; 31.4.2.6101aiii,biii; 31.4.2.6261; 31.4.2.5542).

Description. Parallel-margined leaf fragments, mostly tiny and carbonized, up to $50 \mathrm{~mm}$ long and $10 \mathrm{~mm}$ wide, margin inconspicuously serrate; venation parallel, with numerous similarly thick primary veins, interspaced $\sim 0.15 \mathrm{~mm}$, dense, almost perpendicular interconnecting veins (15-25 per $5 \mathrm{~mm}$ ); stomata in rows parallel to primary veins, $\sim 20$ stomata per $\mathrm{mm}$, epidermal cells elongated, papillose, $\sim 60-80 \mu \mathrm{m}$ long.

Remarks. These tiny leaf fragments are quite common in Pitsidia, but due to their small size they are not easily detected. The original size of the leaves is unknown. The epidermis structure of several specimens is wellpreserved (Fig. 21).

\section{Monocotylophyllum sp. 3}

Pl. 21, fig. 12

Material. Pitsidia, one leaf fragment (Nr. 31.4.2.8254).
Description. Tiny leaf fragment of a probably linear leaf, $7 \mathrm{~mm}$ long and $4 \mathrm{~mm}$ wide, venation parallel, with numerous veins of similar thickness at intervals of $\sim 0.5 \mathrm{~mm}$, interconnected by (almost) perpendicular cross veins, $3-5$ per $5 \mathrm{~mm}$.

Remarks. This fragment closely resembles Monocotylophyllum sp. 2 but the venation is less dense.

\section{Monocotylophyllum sp. 4}

Pl. 21, fig. 1

Material. Pitsidia, one leaf fragment (Nr. 31.4.2.1562ai,bi).

Description. Leaf fragment probably linear in shape, $33 \mathrm{~mm}$ long and $3.5 \mathrm{~mm}$ wide, slightly V-shaped in cross section, margin probably serrate with inconspicuous teeth, one primary vein, moderately thick, 10-12 very thin secondaries, hardly visible, running across lamina and paralleling the primary vein.

Remarks. This leaf differs from the other monocotyledon remains by the $\mathrm{V}$-shape, the serrate margin and the venation pattern.

\section{Monocotylophyllum sp. 5}

Pl. 21, fig. 2; Pl. 22, fig. 3

Material. Pitsidia, two leaf fragments (Nrs 31.4.2.4697aiii,biii, 31.4.2.4904).

Description. Parallel-sided leaf fragments, 22 and $40 \mathrm{~mm}$ long, 8 and $15 \mathrm{~mm}$ wide, entiremargined; venation parallel, primary veins $\sim 14-18$, interspaced $\sim 0.5-0.8 \mathrm{~mm}$, secondary veins thin, hardly visible, running parallel to primaries.

Remarks. These leaves are broader than the afore-described ones. The main veins are distinct, with numerous parallel veins between them but without oblique or perpendicular veinlets.

\section{Monocotylophyllum sp. 6}

Pl. 22, fig. 4

Material. Kassanoi, three leaf fragments (Nrs 31.6.2.15vi; 31.6.2.83op; 31.6.2.199).

Description. Leaf shape probably broad linear, $>47 \mathrm{~mm}$ long and $31 \mathrm{~mm}$ wide, entiremargined; venation parallelodromous, primary vein single, strong, forming prominent keel, 

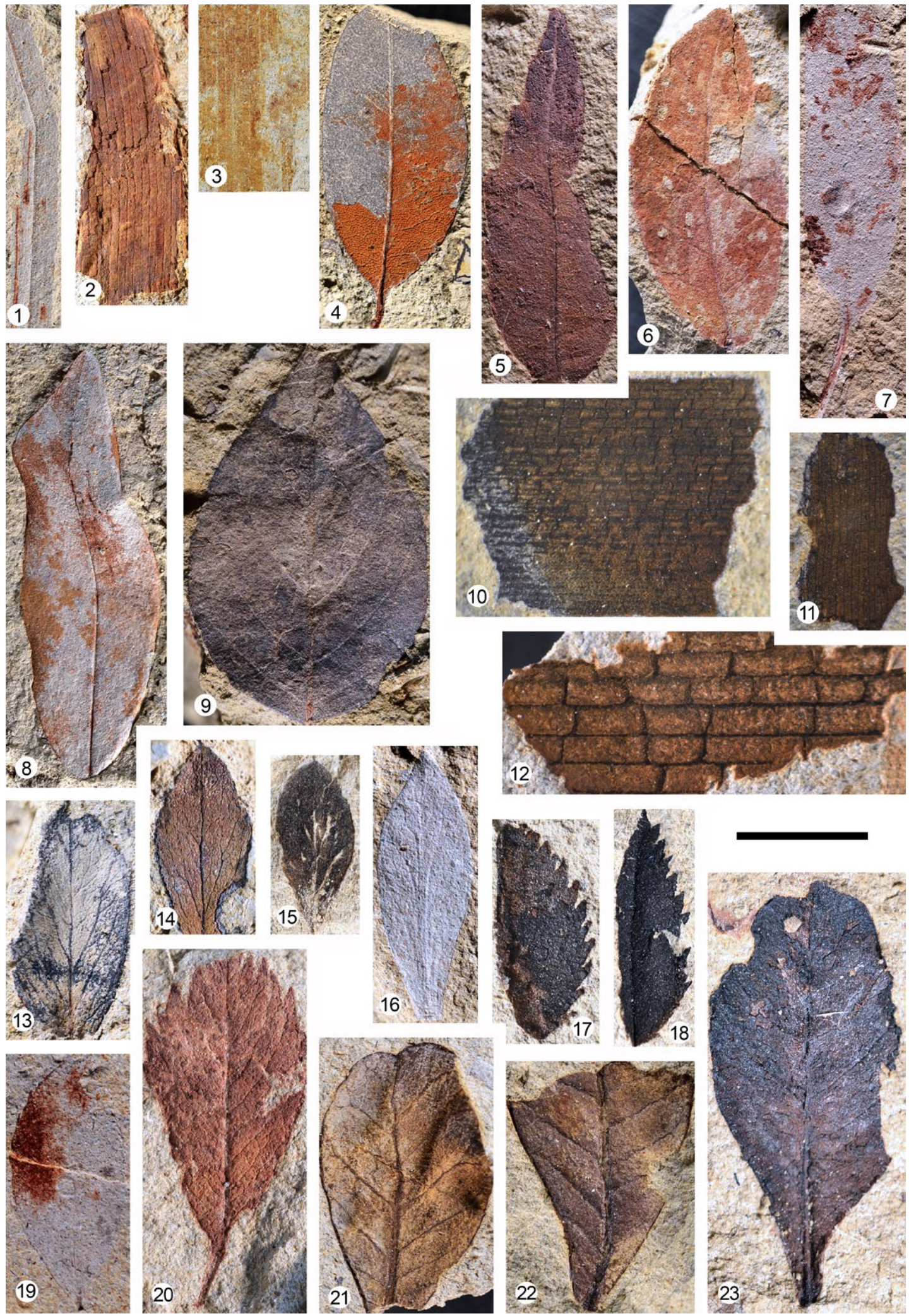

Plate 21. Cretan palaeofloras, scale bar $=1 \mathrm{~cm}$ (unless otherwise stated); 1. Monocotylophyllum sp. 4, Pitsidia, Nr. 31.4.2.1562ai; 2. Monocotylophyllum sp. 5, Pitsidia, Nr. 31.4.2.4697biii; 3. Monocotylophyllum sp. 9, leaf fragment, Metochia, Nr. 31.5.2.41aii; 4. Dicotylophyllum sp. 2, Pitsidia, Nr. 31.4.2.5902b; 5. Dicotylophyllum sp. 3, Pitsidia, Nr. 31.4.2.8255; 6. Dicotylophyllum sp. 4, Pitsidia, Nr. 31.4.2.6997; 7. Dicotylophyllum sp. 5, Pitsidia, Nr. 31.4.2.5306; 8. Dicotylophyllum sp. 6, Pitsidia, Nr. 31.4.2.5929i; 9. Dicotylophyllum sp. 12, Pitsidia, Nr. 31.4.2.6987a; 10, 11. Monocotylophyllum sp. 2, Pitsidia, scale bar $=2$ $\mathrm{mm} ; \mathbf{1 0}$. tiny leaf framgment, Nr. 31.4.2.4955; 11. tiny leaf framgment, Nr. 31.4.2.3198op; 12. Monocotylophyllum $\mathrm{sp.} 3$, tiny leaf framgment, Pitsidia, Nr. 31.4.2.8254, scale bar $=2 \mathrm{~mm} ; \mathbf{1 3 - 1 6}$. Dicotylophyllum sp. 7, Pitsidia, scale bar $=5 \mathrm{~mm} ; \mathbf{1 3}$. Nr. 31.4.2.4699a; 14. Nr. 31.4.2.5650; 15. Nr. 31.4.2.4283ii; 16. Nr. 31.4.2.4502a; 17, 18. Dicotylophyllum sp. 8, Pitsidia, scale bar $=5$ mm; 17. Nr. 31.4.2.1269i; 18. Nr. 31.4.2.4283i; 19. Dicotylophyllum sp. 9, Pitsidia, Nr. 31.4.2.3592ii, scale bar = 5 mm; 20. Dicotylophyllum sp. 10, Pitsidia, Nr. 31.4.2.1922, scale bar $=5 \mathrm{~mm} ; \mathbf{2 1 - 2 3}$. Dicotylophyllum sp. 11, Pitsidia, scale bar $=5 \mathrm{~mm}$; 21. Nr. 31.4.2.4182ai; 22. Nr. 31.4.2.4651aii; 23. Nr. 31.4.2.8109 

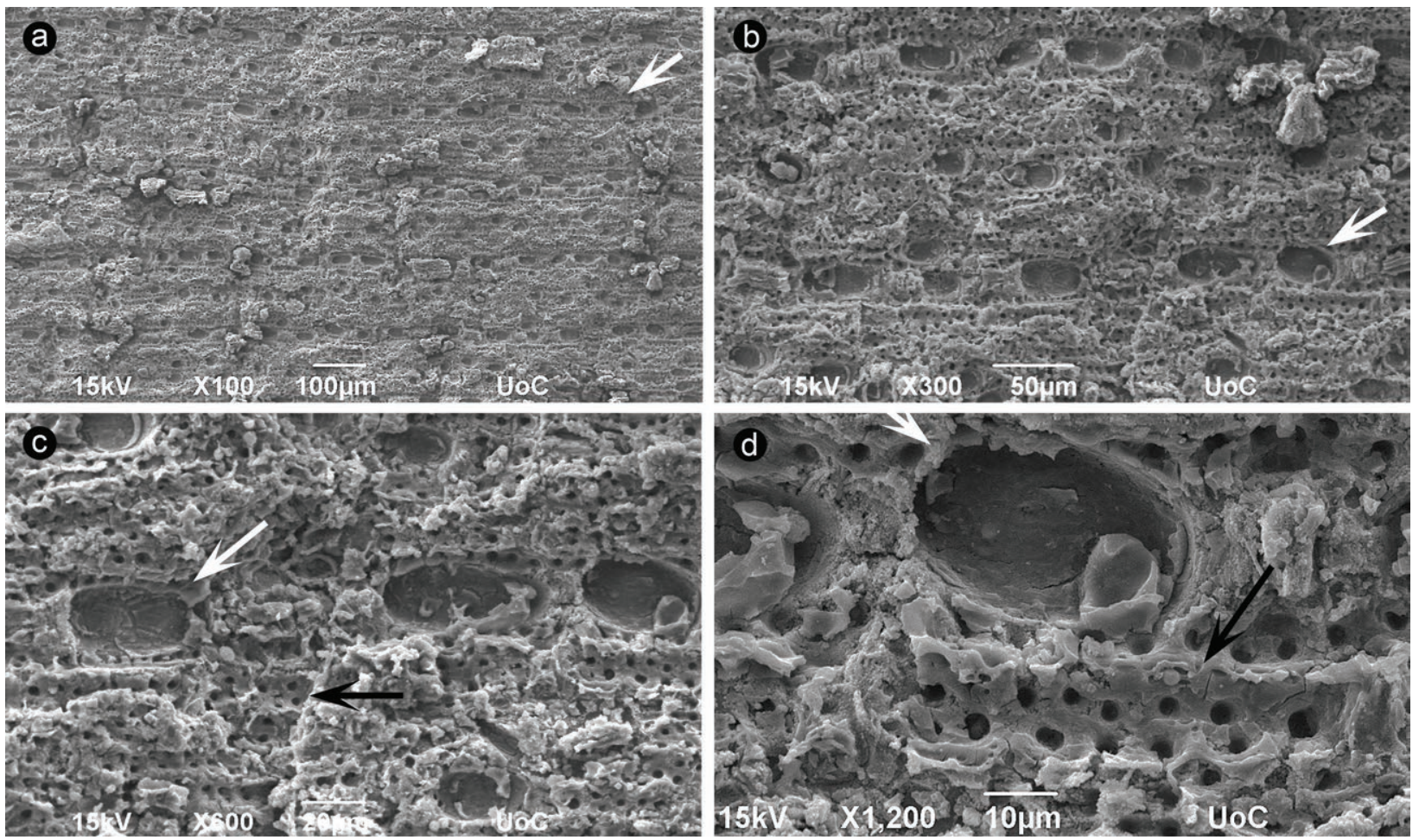

Fig. 21. Palaeoflora of Pitsidia. a-d. Monocotylophyllum sp. 2, coalified leaf fragment; stoma rows, substomatal chambers (white arrows) and elongated, papillose epidermal cells (black arrows) visible, SEM, Nr. 31.4.2.4955 detail

secondary veins parallel to midrib, numerous, delicate, interspaced $0.4-0.6 \mathrm{~mm}$, higher-order venation not visible.

Remarks. This leaf shows a prominent primary vein and numerous secondaries.

\section{Monocotylophyllum sp. 7}

Pl. 22, fig. 5

Material. Kassanoi, one leaf fragment (Nr. 31.6.2.203).

De s c riptio n. Leaf fragment linear, $>57 \mathrm{~mm}$ long and $16 \mathrm{~mm}$ wide, entire-margined; venation parallelodromous, primary veins numerous, delicate, indistinct, straight, interspaces $0.5-0.6 \mathrm{~mm}$, no veinlets present.

Remarks. This specimen is morphologically close to Monocotylophyllum sp. 5 but is distinguished by its delicate primary veins.

\section{Monocotylophyllum sp. 8}

Pl. 22, fig. 6

Material. Kassanoi, one leaf fragment (Nr. 31.6.2.184).

Description. Leaf probably broad linear, $>96 \mathrm{~mm}$ long and 24 wide, margin not preserved; venation parallelodromous, primary veins numerous, $>15$, moderately thick, interspaced $2 \mathrm{~mm}$, veinlets perpendicular to primary veins, distinct, interspaces $\sim 1.5 \mathrm{~mm}$.

Remarks. This fragment somewhat resembles Monocotylophyllum sp. 3 but the venation is less dense.

\section{Monocotylophyllum sp. 9}

\section{Pl. 21, fig. 3}

Mate rial. Metochia, two leaf fragments (Nrs 31.5.2.10; 31.5.2.41aii).

Description. Leaf fragments probably linear, 11-26 mm long and 8-9 mm wide, entiremargined; venation parallelodromous, primary veins numerous, interspaced $\sim 1 \mathrm{~mm}$, secondary veins thinner than primaries; transverse veinlets not detected.

Remarks. Such leaf fragments of monocotyledonous affinity are very rare in Metochia. They resemble Monocotylophyllum sp. 5 but their venation is less dense.

\section{Monocotylophyllum sp. 10}

Pl. 22, fig. 8

Material. Metochia, one incomplete leaf (Nr. 31.5.2.40a,b). 

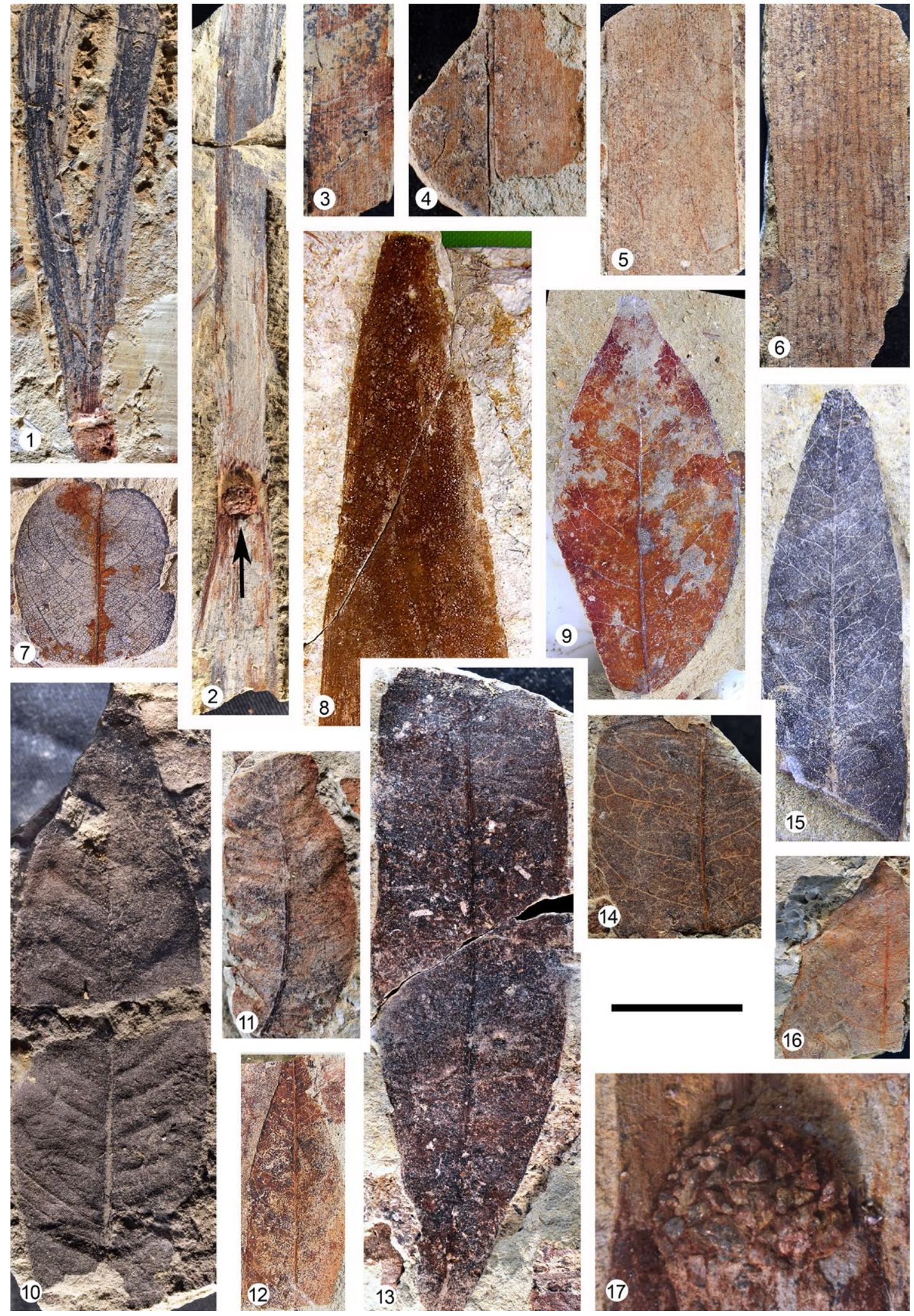

Plate 22. Cretan palaeofloras, scale bar $=2 \mathrm{~cm}$ (unless otherwise stated); 1, 2. Monocotylophyllum sp. 1, Pitsidia; 1. two basically connected linear leaves, Nr. 31.4.2.1182ai; 2. linear leaf with sand accumulation close to base (arrow), Nr. 31.4.2.2425a; 3. Monocotylophyllum sp. 5, Pitsidia, Nr. 31.4.2.4904; 4. Monocotylophyllum sp. 6, Kassanoi, Nr. 31.6.2.83op; 5. Monocotylophyllum sp. 7, Kassanoi, Nr. 31.6.2.203; 6. Monocotylophyllum sp. 8, Kassanoi, Nr. 31.6.2.184; 7. Dicotylophyllum sp. 1, Pitsidia, Nr. 31.4.2.5216i; 8. Monocotylophyllum sp. 10, incomplete broad leaf, Metochia, Nr. 31.5.2.40a; 9. Dicotylophyllum sp. 13, Pitsidia, Nr. 31.4.2.4250a; 10, 11. Dicotylophyllum sp. 14, Kassanoi; 10. Nr. 31.6.2.5; 11. Nr. 31.6.2.165i; 12-15. Dicotylophyllum sp. 15, Kassanoi; 12. Nr. 31.6.2.16i; 13. Nr. 31.6.2.20; 14. fragment of large leaf, Nr. 31.6.2.15i; 15. Nr. 31.6.2.17; 16. Dicotylophyllum sp. 16, Kassanoi, Nr. 31.6.2.70; 17. Monocotylophyllum sp. 1, sand accumulation, close-up, Pitsidia, Nr. 31.4.2.2425b detail, scale bar $=3 \mathrm{~mm}$ 
Description. Lamina coriaceous, shape broad, not parallel-sided, $115 \mathrm{~mm}$ long and $35 \mathrm{~mm}$ wide, fragmentary, entire-margined, venation indistinct, parallelodromous, primary veins numerous, $3-5$ delicate secondary veins between two primary ones.

Re $\mathrm{m}$ a r ks. This specimen is well distinguished by its broad shape. Its thickness explains its indistinct venation.

\section{Dicotyledonae}

\section{Genus Dicotylophyllum Saporta}

\section{Dicotylophyllum sp. 1}

Pl. 22, fig. 7

Material. Pitsidia, one leaf, fragmentary (Nr. 31.4.2.5216i).

Description. Upper part of a probably obovate leaf, lamina $28 \mathrm{~mm}$ long (incomplete) and $24 \mathrm{~mm}$ wide, apex emarginate, margin entire; venation eucamptodromous to weakly brochidodromous, primary vein stout, straight, secondary veins almost opposite to alternate, arising at $55-80^{\circ}$, interspaced $5-9 \mathrm{~mm}$, curved, not entirely parallel to each other, intersecondary veins 1-2 per intercostal area, parallel to secondaries, well developed, reaching more than half the length of secondaries, tertiary veins weakly percurrent, opposite to alternate, higher-order veins regular quadrangular or pentagonal.

Remarks. Although fragmentary, the venation of this leaf is rather distinct. The emarginate shape of the apex probably is a result of damage. A Lauraceae affinity for this specimen is possible.

\section{Dicotylophyllum sp. 2}

Pl. 21, fig. 4

Material. Pitsidia, two incomplete leaves (Nrs 31.4.2.5471ai,bi; 31.4.2.5902a,b).

Description. Leaf petiolate, coriaceous, petiole $3.5 \mathrm{~mm}$ long, complete, lamina elliptic, $\sim 25-30 \mathrm{~mm}$ long and $12-14 \mathrm{~mm}$ wide, $\mathrm{L} / \mathrm{W}$ ratio $\sim 2.1$, slightly asymmetric, base obtuse, apex not preserved, margin entire; venation brochidodromous, midvein thick, almost straight, secondary veins numerous, rather indistinct, arising at $50-80^{\circ}$, straight, intersecondaries present, weak, tertiary veins reticulate, quaternary veins forming irregular quadrangular to pentagonal network.

Remarks. This leaf appears rather coriaceous, indicating evergreen origin.

\section{Dicotylophyllum sp. 3}

Pl. 21, fig. 5

Material. Pitsidia, one almost complete leaf/ leaflet (Nr. 31.4.2.8255).

Description. Lamina lanceolate, $29 \mathrm{~mm}$ long and $9 \mathrm{~mm}$ wide, L/W ratio 3.2 , base rounded, apex acute, margin coarsely, simply dentate, teeth unequal in size, irregularly spaced, sinus shallow, mostly rounded, teeth blunt, basal side convex to flexuous, apical side concave to straight; venation craspedodromous to brochidodromous, primary vein moderately thick, almost straight, secondary veins delicate, vaguely visible, originating at $30-65^{\circ}$, curved, innervating the tooth or forming loops close to margin.

Remarks. The affinity of this leaf or leaflet is unknown.

\section{Dicotylophyllum sp. 4}

Pl. 21, fig. 6

Material. Pitsidia, two complete leaves or leaflets (Nrs 31.4.2.1879; 31.4.2.6997).

Description. Probably subsessile leaves or leaflets, lamina chartaceous, elliptic to obovate, 26 and $36 \mathrm{~mm}$ long and $12 \mathrm{~mm}$ wide, $\mathrm{L} / \mathrm{W}$ ratio $2.2-3$, base rounded, slightly asymmetric, apex bluntly acute, entire-margined; venation brochidodromous, primary vein strong, gently bent, secondary veins moderately strong, in $\sim 8$ mainly subopposite pairs, arising at $45-70^{\circ}$, interspaced $2-4 \mathrm{~mm}$, course straight to curved, forming loops close to margin, higher-order venation not visible.

Remarks. These remains likely are lateral leaflets of compound leaves.

\section{Dicotylophyllum sp. 5}

Pl. 21, fig. 7

Material. Pitsidia, one complete leaf (Nr. 31.4.2.5306).

Description. Leaf long-petiolate, petiole $>8 \mathrm{~mm}$ long, lamina oblong, $\sim 30 \mathrm{~mm}$ long 
(incomplete) and $8 \mathrm{~mm}$ wide, base acute, asymmetric, apex not preserved, margin entire; primary vein strong, slightly curved, secondaries hardly visible, arising at $40-55^{\circ}, \pm$ straight, higher-order veins not visible.

R e marks. The poor preservation of this longpetiolate, entire-margined leaf hinders any further assignment.

\section{Dicotylophyllum sp. 6}

Pl. 21, fig. 8

Material. Pitsidia, one complete leafleaflet (Nr. 31.4.2.5929i).

Description. Lamina probably coriaceous, elliptic, somewhat asymmetric, $33 \mathrm{~mm}$ long and $10 \mathrm{~mm}$ wide, $\mathrm{L} / \mathrm{W}$ ratio 3.3 , base rounded, apex acute, entire-margined; primary vein moderately thick, S-like, secondary veins very delicate, arising at $40-60^{\circ}$, straight, forked close to margin.

Remarks. This specimen lacks diagnostic features for a more accurate determination.

\section{Dicotylophyllum sp. 7}

Pl. 21, figs 13-16

M a t e ri al. Pitsidia, 4 complete or almost complete leaves (Nrs 31.4.2.4283ii; 31.4.2.4502a,b; 31.4.2.4699a,b; 31.4.2.5650).

Description. Small leaves, lamina obovate to spatulate or elliptic, $6.5-10 \mathrm{~mm}$ long and 4-5 mm wide, L/W ratio $1.3-2.5$, base narrow cuneate, apex acute to shortly acuminate or obtuse, entire-margined, venation brochidodromous, primary vein moderately thick and straight, secondary veins almost equally thick as midrib, originating at acute angles of $25-45^{\circ}$, in 5-6 pairs, ascending steeply, straight, onceto multi-forked, forming weak, angular loops with branchlets of adjacent secondaries close to margin, the first 2 or 3 pairs of secondaries more prominent, reaching close to apex, tertiary veins hardly visible, reticulate.

Remarks. This foliage is well distinguished by several features such as the small, mainly obovate lamina as well as the dense, steeply ascending and forked secondaries which diverge from the midrib at rather narrow angles. The venation pattern resembles Hedera multinervis Kolakovsky. The material from Pitsidia differs by the small leaf size.

\section{Dicotylophyllum sp. 8}

Pl. 21, figs 17,18

Material. Pitsidia, two incomplete leaves/ leaflets (Nrs 31.4.2.1269i; 31.4.2.4283i).

Description. Small leaves/leaflets, lamina coriaceous, ovate, $8-9 \mathrm{~mm}$ long and $4-6 \mathrm{~mm}$ wide, L/W ratio $\sim 1.7-2$, base rounded, apex acute to obtuse, margin serrate, teeth sharp, densely spaced, 6 per $0.5 \mathrm{~cm}$, basal side convex, apical side concave, sinus deep, angular; venation craspedodromous, primary vein thick, almost straight, secondary veins hardly visible.

Remarks. The large, sharp teeth of these specimens are very characteristic, resembling Rosaceae. The systematic affinity of these leaves should remain open.

\section{Dicotylophyllum sp. 9}

Pl. 21, fig. 19

Material. Pitsidia, one complete leaf (Nr. 31.4.2.3592ii).

Description. Leaf short petiolate, lamina chartaceous, elliptic, $10 \mathrm{~mm}$ long and $4 \mathrm{~mm}$ wide, L/W ratio 2.5 , base cuneate, apex damaged, margin coarsely serrate at upper 2/3 part of lamina, teeth small, sharp, sinuses narrow, angular; primary vein moderately thick, almost straight, secondary veins very fine, initially severely bent, close to margin indistinct.

Remarks. The size of this leaf, its subsessile character and the type of the marginal teeth resemble the extant Mediterranean shrub Phillyrea latifolia L. (Oleaceae).

\section{Dicotylophyllum sp. 10}

$$
\text { Pl. 21, fig. } 20
$$

Material. Pitsidia, one complete leaf (Nr. 31.4.2.1922).

Description. Leaf petiolate, petiole $>2 \mathrm{~mm}$ long, lamina obovate, $12 \mathrm{~mm}$ long and $7 \mathrm{~mm}$ wide, $\mathrm{L} / \mathrm{W}$ ratio 1.7 , base cuneate, apex not preserved, entire-margined, at upper quarter of lamina serrate, teeth densely spaced, triangular, sharp; venation mostly craspedodromous, primary vein strong, straight, secondary veins in 9-10 pairs, originating at narrow angles, straight or gently curved, the upper pairs innervating the marginal teeth, tertiaries 
reticulate, forming an irregular network with higher-order venation.

Remarks. The lamina shape as well as the serration are characteristic. A Rosaceae affinity (e.g. Crataegus or Rosa) is possible for this specimen.

\section{Dicotylophyllum sp. 11}

Pl. 21, figs 21-23

M a te ri a l. Pitsidia, 5 complete and 2 fragmentaryleaves(Nrs. 31.4.2.3163ai,b; 31.4.2.4182ai,b; 31.4.2.4651aii,b; 31.4.2.4782a,b; 31.4.2.4971ii; 31.4.2.5215; 31.4.2.8109).

Description. Lamina obovate to broadly elliptic, 6-22 mm long and 2.5-11 mm wide, $\mathrm{L} / \mathrm{W}$ ratio 2 , apex emarginate to obtuse, base narrow cuneate to decurrent, entire-margined; venation brochidodromous, primary vein strong, initially straight or slightly bent, zig-zag at upper third of lamina, secondaries delicate, in $5-10$ pairs, originating at $35-70^{\circ}$, straight or almost so, forked close to margin, forming open loops with adjacent ones, intersecondary veins rare, parallel to secondaries, weak, tertiaries reticulate.

Remarks. The systematic affinity of this unusual foliage is unclear.

\section{Dicotylophyllum sp. 12}

\section{Pl. 21, fig. 9}

Material. Pitsidia, one complete leaf (Nr. 31.4.2.6987a,b).

Description. Leaf petiolate, petiole $\sim 3 \mathrm{~mm}$ long, lamina chartaceous, ovate to almost elliptic, $29 \mathrm{~mm}$ long and $17.5 \mathrm{~mm}$ wide, $\mathrm{L} / \mathrm{W}$ ratio 1.7, apex acute, base widely rounded, margin entire or with inconspicuous teeth in apical part; venation ?eucamptodromous, primary vein stout, straight, secondary veins in $\sim 6$ pairs, delicate, sub-oppositely positioned, arising at $30-50^{\circ}$, angles decreasing distally, interspaces $3-5 \mathrm{~mm}$ increasing distally, running uniformly in wide arcs over their whole length towards margin, intersecondaries not observed, tertiary veins hardly visible.

Remarks. This small leaf shows affinities to Alnus (Betulaceae), especially in the lamina shape, the secondary vein course and the possible occurrence of tiny marginal teeth.
Nevertheless, a different systematic position cannot be ruled out.

\section{Dicotylophyllum sp. 13}

Pl. 22, fig. 9

Material. Pitsidia, one almost complete leaf (Nr. 31.4.2.4250a).

Description. Lamina possibly slightly coriaceous, shape elliptic, $\sim 65 \mathrm{~mm}$ long and $31 \mathrm{~mm}$ wide, L/W ratio 2.1; base convex to slightly rounded, somewhat asymmetric; apex acuminate, margin entire; venation brochidodromous, primary vein stout, straight, secondary veins distinctly weaker, in 8 pairs, alternate, originating at $50-70^{\circ}$ from midrib, irregularly spaced, straight or gently curved, forking at some distance from margin, forming loops with adjacent one, additonal loops formed by higher-order venation as well, single weak intersecondary veins present, tertiaries very delicate but distinct, reticulate, higher-order venation forming regular polygonal network.

Remarks: The entire margin, the acuminate apex, the brochidodromous pattern of the main veins and the regular network of higherorder venation suggest a Nyssa origin of this specimen. This leaf superficially resembles Dicotylophyllum sp. 2 described by Knobloch and Velitzelos (1986a) from Elassona, but that specimen bears small marginal teeth and a prominent basal pair of secondaries reaching up to the middle of the lamina.

\section{Dicotylophyllum sp. 14}

Pl. 22, figs 10,11

Material. Kassanoi, two leaves, incomplete (Nrs 31.6.2.5; 31.6.2.165i).

Description. Lamina likely coriaceous, shape oblong to lanceolate, $>95 \mathrm{~mm}$ long and $21-30 \mathrm{~mm}$ wide, $\mathrm{L} / \mathrm{W}$ ratio $\sim 3.8$, apex bluntly acute, base missing, entire-margined; venation brochidodromous, primary vein stout, straight or bent, secondary veins in $>15$ pairs, rather strong, undulating the lamina, originating at $55-80^{\circ}$ at intervals of $4-8 \mathrm{~mm}$, higher-order venation hardly visible.

Remarks. This taxon has large leaves with coriaceous, conspicuously undulating lamina. Its origin remains unknown. 


\section{Dicotylophyllum sp. 15}

Pl. 22, figs $12-15$

Material. Kassanoi, 17 fragmentary leaves (Nrs 31.6.2.4; 31.6.2.8; 31.6.2.10; 31.6.2.11; 31.6.2.12; 31.6.2.120iv; 31.6.2.13; 31.6.2.14; 31.6.2.158iii; 31.6.2.15i; 31.6.2.16i; 31.6.2.16ii; 31.6.2.17; 31.6.2.171aop; 31.6.2.19; 31.6.2.20; 31.6.2.21).

Description. Lamina texture probably coriaceous, shape oblong to elliptic, $>100 \mathrm{~mm}$ long and $22-31 \mathrm{~mm}$ wide, $\mathrm{L} / \mathrm{W}$ ratio $\sim 4-5$, base decurrent, apex acute to acuminate, margin entire; venation semicraspedodromous, primary vein stout, straight to gently bent basally, secondary veins much thinner, numerous ( $>12$ pairs), interspaces $5-8 \mathrm{~mm}$, arising at $35-80^{\circ}$, slightly zig-zag in course, dichotomising close to margin, one branch reaching margin, the other often forming weak, angular loops with supradjacent secondary, intersecondary veins 1-2 per intercostal area, parallel or almost so, more than half of the secondary long, tertiary veins delicate, oblique to perpendicular to secondaries, bent or S-like, joining secondaries with adjacent intersecondaries, higher-order venation not preserved.

Re m arks. These elongate leaves are common in the assemblage. Their large size, and especially the rather irregular venation pattern, with delicate secondaries showing a slight zig-zag in their course, and intersecondaries, are very characteristic and make them easily distinguishable from other elongate, entiremargined leaf forms in this assemblage.

\section{Dicotylophyllum sp. 16}

Pl. 22, fig. 16

Material. Kassanoi, one leaf fragment (Nr. 31.6.2.70).

Description. Lamina fragmentary, $\sim 3.5 \mathrm{~cm}$ long ( $>5 \mathrm{~cm}$ when complete) and $\sim 3 \mathrm{~cm}$ wide, base missing, apex acute, margin coarsely, sharply dentate, teeth triangular with straight to concave sides and acute apex, sinus shallow, broad rounded; venation brochidodromous, secondary veins delicate, originating at wide angles, \pm bent, forming loops near margin, loops sending veinlets towards margin which either innervate the teeth or form smaller loops with adjacent veinlets, intersecondary veins one per intercostal area, half of the secondary long, parallel to secondaries, tertiary veins reticulate, forming irregular network.

Rem arks. This fragment of a broad, toothed leaf resembles Mahonia L. and Ilex L. based on the margin and secondary venation pattern.

\section{Dicotylophyllum sp. 17}

Pl. 23, figs 1,2

Material. Kassanoi, 2 complete or almost complete leaves and 3 fragmentary ones (Nrs 31.6.2.22; 31.6.2.27; 31.6.2.31,39; 31.6.2.33i; 31.6.2.38).

Description. Leaves petiolate, petiole moderately thick, 5.5-9 long, lamina chartaceous, lanceolate to oblong or narrow elliptic, 33 to $\sim 42 \mathrm{~mm}$ long and $10-16 \mathrm{~mm}$ wide, $\mathrm{L} / \mathrm{W}$ ratio $3-4$, base obtuse convex, apex acute or occasionally obtuse, margin entire; venation eucamptodromous, primary vein moderate, slightly curved, secondary veins very delicate, mostly in 10-12 pairs, alternate to subopposite, arising from primary vein at $35-50^{\circ}$ proximally and $60-70^{\circ}$ distally, interspaced 2-6 mm, gently curved, reaching margin, intersecondary veins one or rarely two per intercostal area, half the length of secondaries, tertiary veins percurrent, opposite, perpendicular to oblique to secondaries, mostly curved or S-like, higher-order venation not visible.

R e m a rks. No assignment of these remains to a specific taxon of dicots is possible.

\section{Dicotylophyllum sp. 18}

Pl. 23, fig. 3

Material. Kassanoi, a complete leaf and one fragment (Nrs 31.6.2.117; 31.6.2.162).

Description. Lamina shape broad elliptic, $36-45 \mathrm{~mm}$ long and $23-32 \mathrm{~mm}$ wide, $\mathrm{L} / \mathrm{W}$ ratio 1.4-1.6, base rounded, apex bluntly acute, margin entire to somewhat undulate; venation eucamptodromous, primary vein moderately thick, straight, secondary veins alternate, originating at $30-60^{\circ}$ (angles decreasing distally), interspaces wide, $3.5-13 \mathrm{~mm}$ (distances increasing distally), course curved, tertiary veins distinctly more delicate than secondaries, 
very dense, 20 per $\mathrm{cm}$, percurrent, \pm straight, perpendicular to widely acute to the primary vein, higher-order venation hardly visible.

Remarks. The overall gross morphology of these specimens suggests affinities to Cornaceae (e.g. Cornus) or Rhamnaceae (e.g. Rhamnus, Berchemia, Rhamnidium).

\section{Dicotylophyllum sp. 19}

Pl. 23, figs 4,5

Material. Kassanoi, 2 complete and one fragmentary leaf (Nrs 31.6.2.102; 31.6.2.119x; 31.6.2.195).

Description. Leaf petiolate, petiole moderately thick, $\sim 2 \mathrm{~mm}$ long; lamina \pm coriaceous, obovate, $12-16 \mathrm{~mm}$ long, $6-9 \mathrm{~mm}$ wide, $\mathrm{L} / \mathrm{W}$ ratio 1.8-2.7, base narrow cuneate to decurrent, apex emarginate, margin entire; venation camptodromous, primary vein strong, almost straight, secondary veins numerous, fine, densely arranged, $\sim 15$ per $\mathrm{cm}$, arising at $30-45^{\circ}$, running parallel, interspacing with numerous intersecondaries towards margin, tertiary veins oblique to secondaries, joining them, straight, higher-order venation not visible.

Remarks. The systematic position of these leaves remains unknown.

\section{Dicotylophyllum sp. 20}

Pl. 23, fig. 7

Material. Metochia, 3 incomplete leaves (Nrs 31.5.2.30a,b; 31.5.2.35a,b; 31.5.2.42,45).

Description. Leaves petiolate, petiole strong, $>8 \mathrm{~mm}$ long; lamina coriaceous, narrow elliptic to lanceolate, $>60 \mathrm{~mm}$ long and $15-25 \mathrm{~mm}$ wide, $\mathrm{L} / \mathrm{W}$ ratio $\sim 4$, base cuneate, apex acute, margin entire; venation brochidodromous, primary vein strong, straight to smoothly bent, secondary veins much thinner, in $>8$ pairs, arising at $30-80^{\circ}$ (the most acute proximally), looping along margin, intersecondary veins mostly one per intercostal area, of the same course but shorter than secondaries, tertiary veins reticulate, almost perpendicular to secondaries, forming regular network with higher-order veins, areolation 3-4-sided.

Remarks: The gross morphology of these specimens and especially the venation architecture indicate a lauraceous origin.

\section{Dicotylophyllum sp. 21}

Pl. 23, fig. 6

Material. Metochia, one complete leaf (Nr. 31.5.2.1a,b).

Description. Lamina elliptic, $30 \mathrm{~mm}$ long, $15 \mathrm{~mm}$ wide, $\mathrm{L} / \mathrm{W}$ ratio 2 , base rounded, apex acuminate, margin simply, regularly serrate in upper two thirds of lamina, teeth prominent, narrow triangular to hook-like, ending in distinct bristles apically; venation possibly craspedodromous, primary vein strong, gently bent, tapering towards apex, secondary veins much thinner, in $\sim 10$ pairs, arising at $40-70^{\circ}$, \pm bent, indistinct close to margin.

R e m arks. A Fagaceae affinity of this leaf with characteristic bristle-tipped marginal teeth is probable. It could represent an extreme form of Quercus mediterranea.

\section{Male inflorescence}

Fam. et gen. et sp. indet.

Pl. 23, fig. 24

Material. Pitsidia, one incomplete male inflorescence (Nr. 31.4.2.6891).

Des criptio n. Staminate catkin, simple, (sub) cylindrical, secondarily flattened, $15 \mathrm{~mm}$ long and $3 \mathrm{~mm}$ wide, with numerous inconspicuous flowers ( $>20)$, loosely crowded, inflorescence axis unbranched; florets poorly preserved, 1-1.5 mm long, probably spirally arranged on axis.

R e m arks. From the hundreds of catkins available from Pitsidia, this specimen is the only one that does not belong to Myrica, because of the loosely crowded florets on the axis. Its overall appearance is closer to Quercus, but more and better-preserved material is required.

Genus Antholithes Brongniart

\section{Antholithes sp.}

Pl. 23, fig. 19

Material. Kassanoi, a part of a flower (Nr. 31.6.2.118i).

Des cription. Flower remain, probably calyx, actinomorphic to slightly zygomorphic, with five, almost free sepals; sepals $2 \mathrm{~mm}$ long and 1-1.5 mm wide, with slender primary vein. 
Remarks. This specimen probably belongs to a dicotyledonous plant taxon with pentameric flowers. In Makrilia, several isolated flowers have been discovered (Sachse, 2004: Pl. 17, figs 17-19) but none of them resembles the specimen from Kassanoi. Among them, two are octameric and have been identified as Asterocalyx styriacus Ettingshausen (Kovar-Eder et al., 2004).

\section{Fruit}

Fam. et gen. et sp. indet.

$$
\text { Pl. 23, fig. } 18
$$

Material. Kassanoi, one fragmentary fruit (Nr. 31.6.2.80ii).

Description. Winged fruit, incomplete, size $11 \times 8 \mathrm{~mm}$, consisting possibly of a nutlet $\sim 2.5 \mathrm{~mm}$ in diameter encircled by a persistent, thick, five-lobed calyx. Sepals partly preserved, elongate, sinuses between sepals acute, deeply incised; sepal venation consisting of subparallel veins, prominent, \pm equal, arising independently from the base, other veins not visible.

Remarks. Wind-dispersed fruits with a persistent five-lobed calyx occur in various extant genera (e.g. Porana, Dinetus, Astronium, Gluta, Monotes) as well as in the fossil Chaneya Wang et Manchester. In the latter the lobes are entire-margined, elliptic to obovate with rounded apices, and with venation consisting mostly of five longitudinal veins in each lobe, originating independently from the base (Wang and Manchester, 2000). The preserved features of the calyx lobes of the specimen from Kassanoi are morphologically close to this extinct genus.

\section{?Fruit}

Fam. et gen. et sp. indet.

Pl. 23, fig. 14

Material. Metochia, one fragment (Nr. 31.5.2.63).

Description. Possibly a fruit fragment, ovate, $11 \mathrm{~mm}$ long and $11 \mathrm{~mm}$ wide, with two distinct lateral extensions, pedicel $6 \mathrm{~mm}$ long, special features on the external surface absent.

R e m arks. This specimen possibly was part of a fertile organ (e.g. exocarp or cup). Its systematic position remains uncertain.

\section{Bud scales}

Fam. et gen. et sp. indet.

\section{Bud scale type 1}

Pl. 23, fig. 23

Material. Pitsidia, 14 isolated bud scales (Nrs 31.4.2.1275; 31.4.2.3621ai,b; 31.4.2.3702i; 31.4.2.4292; 31.4.2.4389aiii,biii; 31.4.2.5143i; 31.4.2.5692ii; 31.4.2.6151ii; 31.4.2.6171op; 31.4.2.8044; 31.4.2.8050, 8034; 31.4.2.8124a,b; 31.4.2.8185; 31.4.2.8258aiii).

Description. Bud scales broad ovate, $5-11.5$ (average 7.2) $\mathrm{mm}$ long and 6.5-13 (average 9.5) $\mathrm{mm}$ wide, L/W ratio $0.7-0.9$, apex obtuse, rounded, base almost straight or slightly irregular, perpendicularly cutting longitudinal axes of scale, margin entire, a few subparallel linear scars visible at base of scale, other ornamentation or appendages absent.

Re marks. Bud scales are not frequent in Pitsidia. This type of scale is the most abundant one in the assemblage.

\section{Bud scale type 2 \\ Pl. 23, fig. 21}

Mat e rial. Pitsidia, 6 isolated bud scales (Nrs 31.4.2.1629; 31.4.2.3600; 31.4.2.4172i;

31.4.2.4298; 31.4.2.4950,4952;

31.4.2.5823,5815bopi).

Description. Bud scales ovate, $8-13 \mathrm{~mm}$ long and 5-9 $\mathrm{mm}$ wide, L/W ratio 1.4-1.7, apex obtuse, base almost straight or slightly irregular, perpendicularly cutting longitudinal axis of scale, margin entire, occasionally subparallel linear scars visible.

Remarks. This type of bud scale is morphologically very close to the previous one. It differs in its more elongate shape and acute apex.

$$
\begin{gathered}
\text { Bud scale type } 3 \\
\text { Pl. } 23 \text {, fig. } 22
\end{gathered}
$$

Materia l. Pitsidia, 5 isolated bud scales (Nrs 31.4.2.1751iii; 31.4.2.2183bopii;

31.4.2.3030aopiii; 31.4.2.3768ai,bi; 31.4.2.8217).

Description. Bud scales elongated, elliptic to ovate, 11-13 $\mathrm{mm}$ long and 3-7 mm wide, $\mathrm{L} / \mathrm{W}$ ratio $\sim 2.5-3$, apex acute, entire-margined, 

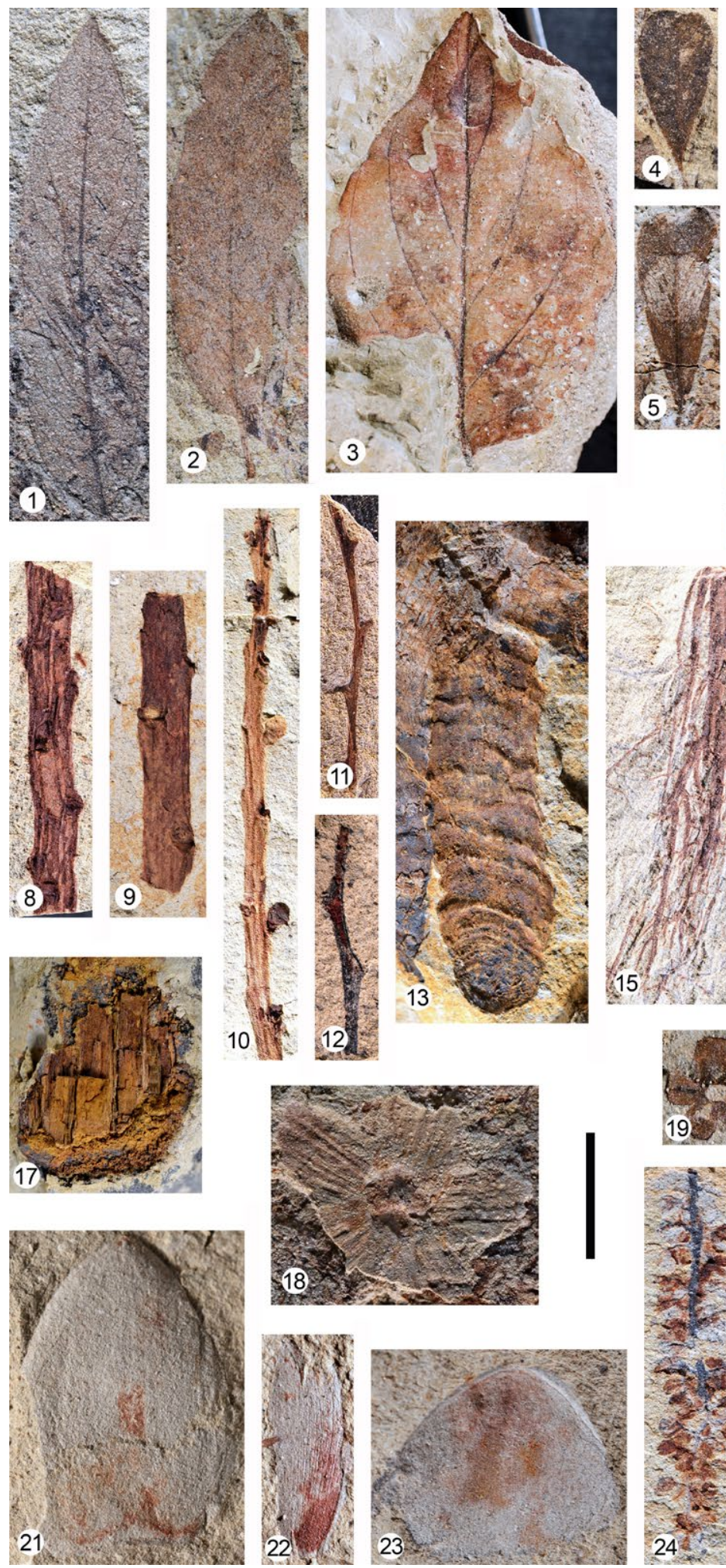

Plate 23. Cretan palaeofloras, scale bar $=1 \mathrm{~cm}$ (unless otherwise stated); 1, 2. Dicotylophyllum sp. 17, Kassanoi; 1. Nr. 31.6.2.33i; 2. Nr. 31.6.2.31; 3. Dicotylophyllum sp. 18, Kassanoi, Nr. 31.6.2.117; 4, 5. Dicotylophyllum sp. 19, Kassanoi; 4. Nr. 31.6.2.195; 5. lamina skeletonization due to arthropod feeding, Nr. 31.6.2.119x; 6. Dicotylophyllum sp. 21, serrate margin with bristle-tipped teeth, Metochia, Nr. 31.5.2.1a; 7. Dicotylophyllum sp. 20, Metochia, Nr. 31.5.2.30a; 8-12. Defoliated long shoots of woody dicots, fam. et. gen. et sp. indet., Pitsidia; 8. Nr. 31.4.2.1163; 9. Nr. 31.4.2.2283i; 10. with well-preserved buds, Nr. 31.4.2.5373b; 11. Nr. 31.4.2.4602i; 12. Nr. 31.4.2.5884aii; 13. ?Rhizome, Nr. 31.4.2.2574ai, Pitsidia; 14. ?Fruit fragment, fam. et gen. et sp. indet., Metochia, Nr. 31.5.2.63; 15, 16. Root remains, fam. et. gen. et sp. indet., Pitsidia; 15. adventitious system, Nr. 31.4.2.1127; 16. adventitious system, Nr. 31.4.2.2957; 17. Fragment of wood as inorganic replica, Pitsidia, Nr. 31.4.2.1835; 18. Winged fruit, fam. et gen. et sp. indet., Kassanoi, Nr. 31.6.2.80ii, scale bar $=5 \mathrm{~mm}$; 19. Antholithes sp., calyx, Kassanoi, Nr. 31.6.2.118i, scale bar $=5 \mathrm{~mm}$; 20. ?Rhizome base with characteristic stirs, Pitsidia, Nr. 31.4.2.2574ai detail, scale bar $=5 \mathrm{~mm} ;$ 21-23. Bud scales, fam. et. gen. et sp. indet., Pitsidia, scale bar $=5 \mathrm{~mm}$; 21. type 2, Nr. 31.4.2.5823; 22. type 3, Nr. 31.4.2.3768ai; 23. type 1, Nr. 31.4.2.4389aiii; 24. Male inflorescence, fam. et gen. et sp. indet., Pitsidia, Nr. 31.4.2.6891, scale bar = $5 \mathrm{~mm}$; 25. Defoliated shoot of woody dicot, cross section, pith (p), cork (c) and epidermis (e), Pitsidia, Nr. 31.4.2.3295, scale bar $=0.75 \mathrm{~mm}$ 
with numerous subparallel, equally strong veins running longitudinally.

Remarks. The overall shape of this material and its venation pattern are close to the buds produced by the genus Acer (Gabrielyan and Kovar-Eder, 2011: Pl. 6 figs 9-41).

\section{Defoliated long shoots / Wood fragments}

Fam. et gen. et sp. indet.

Pl. 23, figs $8-12,17,25$

Material. Pitsidia, 387 fragments of long shoots of woody dicots and 133 small fragments of wood, as inorganic replicas or impressions (see collection numbers in Appendix 2).

Description. Defoliated shoots, mostly fragmentary, diverse in length and diameter, mostly with scars of leaf and buds alternately arranged; also, wood fragments preserved as inorganic replicas, cell-level structures not preserved.

Remarks. Due to the lack of any diagnostic features, these vegetative remains cannot be assigned to a specific plant group. In several specimens the quality of the replica preservation is high (Pl. 23, fig. 25).

\section{?Rhizome}

Fam. et gen. et sp. indet.

$$
\text { Pl. 23, figs 13, } 20
$$

Material. Pitsidia, one fragment (Nr. 31.4.2.2574ai).

Description. Possibly a rhizome fragment, $32 \mathrm{~mm}$ long and $9 \mathrm{~mm}$ wide, with short internodes and numerous characteristic stirs arranged around central point of basal disc.

Remarks. Such specimens are very rare in Pitsidia. They may be rhizome fragments.

\section{Roots}

Fam. et gen. et sp. indet. Pl. 23, figs 15, 16

Material. Pitsidia, 24 root remains, mainly fragmentary (Nrs 31.4.2.1127; 31.4.2.1223iv; 31.4.2.1440; 31.4.2.2066aiii,b; 31.4.2.2178opii; 31.4.2.2279op; 31.4.2.2957; 31.4.2.3073;

31.4.2.3406; 31.4.2.4100a,b; 31.4.2.4643biii;

31.4.2.4725iii; 31.4.2.5010; 31.4.2.5105;

31.4.2.5168; 31.4.2.5472aii; 31.4.2.5609i;

31.4.2.5916; 31.4.2.6666a,b; 31.4.2.6792iii;

31.4.2.7001; 31.4.2.7002; 31.4.2.7003;

31.4.2.7004).

Des c ription. Root remains, either developed from one point in clusters, \pm similarly thick (adventitious), or with a primary root and the lateral ones distinctly thinner (tap).

R e marks. Specimens of roots are uncommon in the assemblage and represent both monocots and dicots.

\section{FLORA, TAPHONOMY AND VEGETATION RECONSTRUCTION}

\section{PITSIDIA}

The palaeoflora of Pitsidia comprises an alga, two ferns, at least five conifers and more than 45 angiosperms (Tab. 1). Conifers are documented mostly by needle-like leaves and needle shoots, and secondarily by ovulate scales, pollen cones and bracts (Fig. 8b). Dicots are represented by leaves and leaflets as well as inflorescences, fruits/seeds and infructescences, whereas monocots are documented only by fragmentary foliage. Most of the examined fertile remains are associated with taxa identified based on foliage such as Pinus, Liquidambar, Podocarpium, Myrica and Acer. The only exception is Pterocarya, represented exclusively by a winged fruit. Arboreal elements prevail in the assemblage, while remains of herbs are less frequent, i.e. five morpho-species of monocots. Floristically the assemblage shows the predominance of deciduous elements comprising $\sim 2 / 3$ of the identified dicots, whereas thermophilic taxa are less common. Regarding leaf size, the highest number of leaves represent microphyll foliage.

The assemblage is characterised by the mass occurrence of two fossil taxa, Myrica and Pinus pitsidiensis, represented by hundreds of vegetative and fertile remains (Tab. 1, Fig. 8c). This allows the first reconstruction of $M$. lignitum whole plant and the identification of a new pine species (Zidianakis et al., 2015, 2016). Among the plant families, Pinaceae, Lauraceae, Fabaceae, Ulmaceae, Fagaceae, 
Salicaceae and Sapindaceae are the most common and diversified. Remarkably, Pitsidia lacks Betulaceae components except for some ambiguous remains (cf. Ostrya sp., Dicotylophyllum sp. 12), although this family is wellknown from several other Miocene European and Cretan floras (i.e. Alnus, Betula, Carpinus). Fagaceae are fairly diverse, with four different species including Fagus as well as lobed and toothed oaks. The leaves of Quercus pseudocastanea and $Q$. kubinyii are most abundant, while $Q$. mediterranea and Fagus gussonii, two common elements in the Cretan fossil record, are represented by just a few leaf remains. Other well-represented woody plants are Daphnogene polymorpha, Liquidambar europaea, Carya sp., Acer tricuspidatum, Рориlus latior and the legumes Podocarpium podocarpum and Mimosites sp. Conifers are mostly represented by various pine species and Taxodium dubium. "Pteris" oeningensis is the only identified fern. The occurrence of Equistum sp., Buxus pliocenica, Quercus drymeja and Comptonia difformis (Zidianakis et al., 2010) was not confirmed.

At Pitsidia and in the adjacent area, the geological and sedimentological settings imply a transitional marine landscape where estuarine palaeoenvironments interfingered with backswamp, floodplain, riverbank and bog habitats located close to the coast (Kröger, 2004). The almost complete absence of organic matter and the medium $\mathrm{CaCO}_{3}$ content in the fossiliferous sequence of Pitsidia reflect a depositional environment with good oxygen circulation, where oxidising conditions prevailed (Zidianakis, 2018). The grain-size of the plant-bearing layers suggests that the plant material was deposited in calm or stagnant waters of shallow depth. Disarticulated bones, mostly of a single fish taxon, are common in the studied deposits. The identified faunal elements reveal freshwater ecological preferences for fishes (Cyprinidae), molluscs (Planorbidae) and ostracods (Candonidae) (Zidianakis, 2018). The lack of entire fish skeletons or articulated bones suggests their allochthonous origin, probably having been transported by water currents.

The assemblage has many rather fragmented leaves; this condition applies to $\sim 65 \%$ of them, implying pre-depositional mechanical damage. The extensive pre-burial mechanical damage reveals that most leaves had clearly undergone transport.
We estimate that about half of the plant findings in Pitsidia comprise foliage, mostly Myrica lignitum, 1700 leaves per $\mathrm{m}^{3}$ sediment (Fig. 8b). Leafy twigs, mostly of Pinus and Taxodium, as well as shoot fragments and scales/bracts, are very common. All these vegetative remains co-occur with fertile plant organs, mostly catkins, fruits/seeds and pollen cones, in considerable numbers that total $\sim 15 \%$ of the collected material (Fig. 8b). Especially for Myrica and P. pitsidiensis, their extreme abundance, along with high organ diversity, probably reflect growth close to the depositional area, and parautochthonous deposition.

According to most authors, the breakup of the Aegeis landmass began in the middle to the late Miocene (Dermitzakis and Papanikolaou, 1981; Dermitzakis, 1990; Meulenkamp and Sissingh, 2003). As a consequence, differently oriented faults in the Messara Basin formed several relatively small intermontane basins in which deposits of variable facies (fluvial, brackish, shallow-marine) accumulated (ten Veen and Postma, 1999; Zachariasse et al., 2011). Understanding the landscape's heterogeneity, vegetation structure and plant associations in the Pitsidia area, the geological, sedimentological and taphonomic evidence, along with leaf physiognomy and putative plant autecology (Appx. 3) are taken into account. For the present phytosociological approach, we applied the vegetation units proposed by Denk (2016: VU 0-7). Apart from the Pitsidia macro-assemblage, we also supplementarily evaluated the time-equivalent pollen and spore flora of Kastellios Hill, located in the eastern part of the Messara Basin (Appx. 1, 3). The pollen record from Kastellios Hill yields a diverse conifer as well angiosperm spectrum of taxa (Sen et al., 1986) (Appx. 4). Although both floras share several taxa, including the dominant Taxodioideae, Myricaceae, Quercus and Carya, Kastellios Hill yields taxa that have not been recorded in Pitsidia. Among them, non-arboreal elements, high-altitude conifers, thermophilic taxa (Engelhardia, Symplocos, Arecaceae) and deciduous mesophytic woody plants such as Carpinus, Corylus, Betula, Juglans, Ilex and Tilia reflect habitats of a wider range.

Two typical floristic elements of swamp vegetation, the conifer Taxodium dubium and the dicot shrub Myrica lignitum, were well documented in both the Pitsidia and Kastellios Hill floras (VU 3). These elements probably were 
Table 1. Plant assemblage of Pitsidia, floristic composition

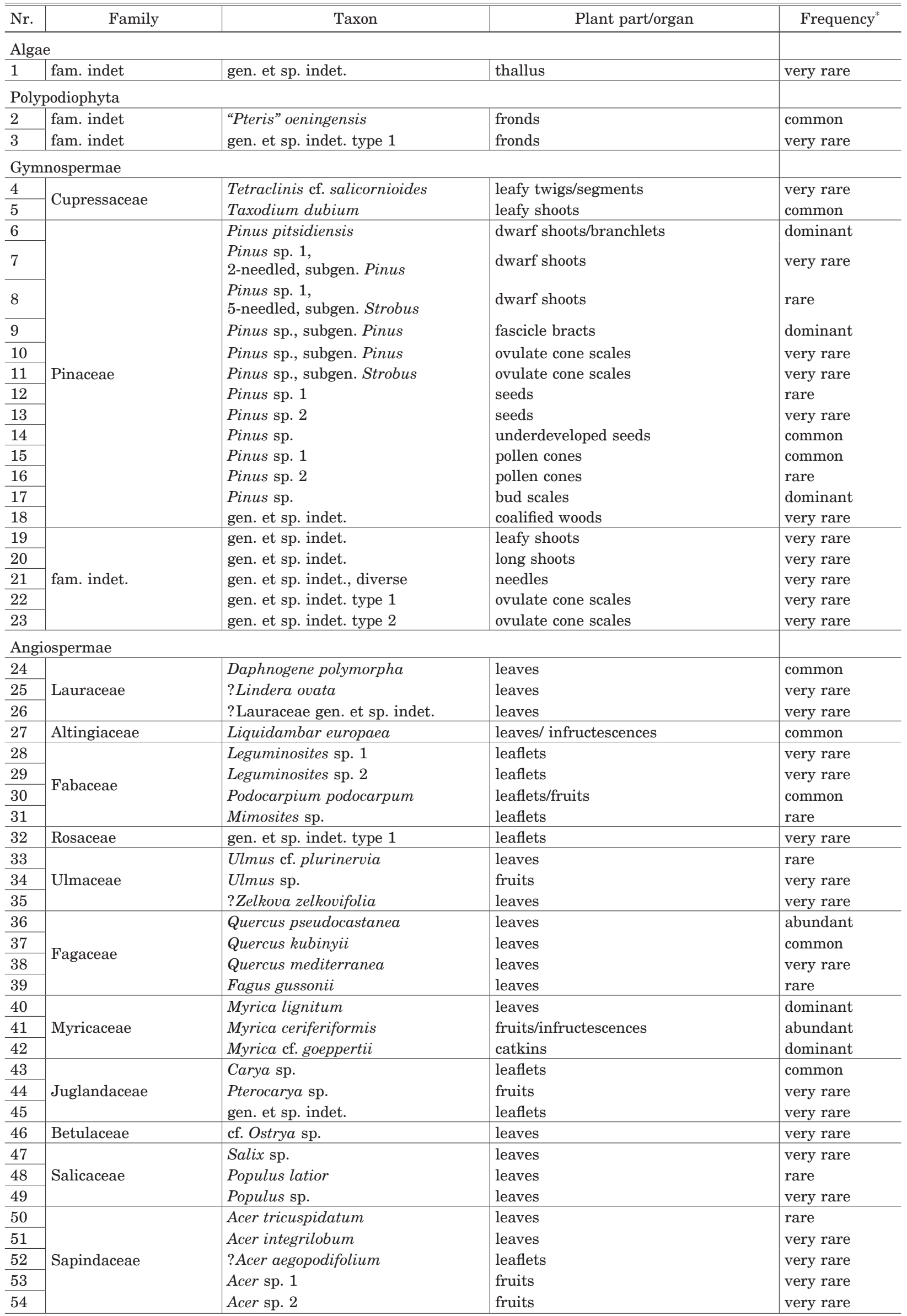


Table 1. Continued

\begin{tabular}{|c|c|c|c|c|}
\hline Nr. & Family & Taxon & Plant part/organ & Frequency" \\
\hline 55 & \multirow{25}{*}{ fam. indet. } & Monocotylophyllum sp. 1 & leaves & rare \\
\hline 56 & & Monocotylophyllum sp. 2 & leaves & rare \\
\hline 57 & & Monocotylophyllum sp. 3 & leaves & very rare \\
\hline 58 & & Monocotylophyllum sp. 4 & leaves & very rare \\
\hline 59 & & Monocotylophyllum sp. 5 & leaves & very rare \\
\hline 60 & & Dicotylophyllum sp. 1 & leaves & very rare \\
\hline 61 & & Dicotylophyllum sp. 2 & leaves & very rare \\
\hline 62 & & Dicotylophyllum sp. 3 & leaves/leaflets & very rare \\
\hline 63 & & Dicotylophyllum sp. 4 & leaves/leaflets & very rare \\
\hline 64 & & Dicotylophyllum sp. 5 & leaves & very rare \\
\hline 65 & & Dicotylophyllum sp. 6 & leaves/leaflets & very rare \\
\hline 66 & & Dicotylophyllum sp. 7 & leaves & very rare \\
\hline 67 & & Dicotylophyllum sp. 8 & leaves/leaflets & very rare \\
\hline 68 & & Dicotylophyllum sp. 9 & leaves & very rare \\
\hline 69 & & Dicotylophyllum sp. 10 & leaves & very rare \\
\hline 70 & & Dicotylophyllum sp. 11 & leaves & very rare \\
\hline 71 & & Dicotylophyllum sp. 12 & leaves & very rare \\
\hline 72 & & Dicotylophyllum sp. 13 & leaves & very rare \\
\hline 73 & & gen. et sp. indet. & inflorescences & very rare \\
\hline 74 & & gen. et sp. indet. type 1 & bud scales & rare \\
\hline 75 & & gen. et sp. indet. type 2 & bud scales & very rare \\
\hline 76 & & gen. et sp. indet. type 3 & bud scales & very rare \\
\hline 77 & & gen. et sp. indet., diverse & $\begin{array}{l}\text { defoliated long shoots of woody dicots/ } \\
\text { wood fragments (inorganic) }\end{array}$ & dominant \\
\hline 78 & & gen. et sp. indet. & ?rhizoms & very rare \\
\hline 79 & & gen. et sp. indet., diverse & roots & rare \\
\hline
\end{tabular}

*very rare $\leq 9$, rare 10-29, common 30-99, abundant 100-299, dominant $\geq 300$

associated in swamp habitats with several broad-leaved deciduous arboreal elements such as Liquidambar europaea, Acer tricuspidatum, Alnus and Nyssa, and possibly Palmae. Modern swamp forests of southeastern North America can serve as the modern equivalent to the expected setting in the Pitisidia region during the Tortonian.

The wet alluvial forest in better-drained areas and along the canals probably included Carya, polars (Populus latior, Populus sp.), Salix, Ulmus, Alnus, Liquidambar europaea and Daphnogene polymorpha (UV4). The occurrence of $M$. lignitum in the understory is likely, whereas ferns such as "Pteris" oeningensis and monocots would be expected as herb layer components.

Based on the abundance of individual taxa in the assemblage, the long-needled Pinus pitsidiensis was probably widespread in the lowlands, forming coastline woodlands potentially associated with $M$. lignitum. Both represent likely elements of early successional stages. The pine forests along the coastal flatlands in southeastern North America serve as a modern analogue, where $P$. palustris forests are widely distributed and $M$. cerifera is one of the understory species
(Miyawaki et al., 1994). Due to parautochthonous deposition, we cannot exclude the possibility that $P$. pitsidiensis thrived on sites with higher soil fertility and moisture close to the wetland, like extant Pinus elliottii Engelmann in Everglades pinelands.

Farther from the deposition area, in the adjacent surroundings, well-drained lowland forests probably comprised deciduous and to a lesser extent broad-leaved evergreen taxa (VU5). Quercus pseudocastanea and Quercus kubinyii in the macrorecord, and Fagaceae in the microflora, are well represented. Daphnogene polymorpha may have been common. Different maples, Carya sp., Tetraclinis cf. salicornioides and several other taxa better captured in the palynological record of Kastellios Hill (Engelhardia, Juglans, Ostrya and other Betulaceae) complement the composition of this zonal vegetation as accessory elements.

Upland forests may have included a Fagus mesic forest (VU6). A number of conifers represented in the microflora, mostly Cedrus, Tsuga, Picea and Abies, along with some broad-leaved deciduous trees such as maples and Betulaceae, may have contributed to these upland forests or formed pure conifer forests. 
The ecological signal of several identified taxa in the macrorecord is difficult to assess. The degree to which some of them (e.g., Dicotylophyllum sp. 2, 7, 8 and 10, several Fabaceae, Quercus mediterranea, two- and five-needled Pinus) represent "sclerophyllous" components remains open (Denk, 2016; Denk, et al. 2017). For instance, modern Fabaceae occur in a wide range of environments and not only in dry areas. The occurrence of sclerophyllous woodlands in lowland areas with less favorable conditions for plants (shallow and relatively dry soils, south-exposed slopes) may be assumed in the surroundings of Pitsidia.

Ephedra and Artemisia, along with Amarathaceae/Chenopodiaceae and Asteraceae pollen, indicate more open habitats (VU0). Taxa with possibly wide ecological ranges such as Zelkova, Ostrya, Palmae and Fabaceae are expected in such open landscapes.

Integrated Plant Record (IPR) Vegetation Analysis (Kovar-Eder and Kvaček, 2007; Kovar-Eder et al., 2008; Teodoridis et al., 2011) was applied to the flora of Pitsidia (Tab. 2, Appx. 5a). This semiquantitaive method serves to determine major zonal vegetation types based on assignment of the taxa to a suite of defined components reflecting the leaf physiognomy and autecology of the taxa. The major vegetation types are defined by the proportions of key components (i.e. zonal taxa). For the palaeoflora of Pitsidia, this approach yielded a subhumid sclerophyllous forest (ShSF) as the most likely zonal vegetation type.

\section{KASSANOI}

The palaeoflora of Kassanoi includes 23 taxa of angiosperms based almost exclusively on leaf remains (Tab. 3). Arboreal elements trees and shrubs - prevail, while herbs (monocots and Decodon gibbosus) are less frequent. Deciduous woody elements comprise about three fifths of the dicot spectrum. Daphnogene polymorpha, Podocarpium podocarpum, Myrica lignitum, ?Salix and Dicotylophyllum sp. 15 are the dominant ones. In this flora, not a single pine remain has been reported and other conifers are scarce, among them a few leafy twigs of Tetraclinis cf. salicornioides. Quercus and Acer, two of the most common genera in the Cretan late Miocene, are represented in Kassanoi by only a few leaves of Quercus sp., while maples are entirely absent.

Based on the alternation of sandy and silty/ clay beds and the presence of freshwater molluscs and in situ root remains, Kassanoi could reflect a fluvio-lacustrine environment. The plant material possibly accumulated at overbank, freshwater reservoirs with fluctuations in water flow that temporarily held rooted plants. The frequent occurrence of plant debris in bedding planes and the high fragmentation rate of the leaf material indicate higher water flow and that some time had passed before the plant material was finally embedded. Wind transport apparently played a minor role, because winged fruits and flower remains are scarce.

In Kassanoi the depositional setting agrees well with the autecology of the reported taxa. Most of them such as Salix cf. angusta, Populus latior, Fraxinus, Daphnogene polymorpha and Myrica lignitum likely belonged to moist broad-leaved gallery forests. This association corresponds to VU4 of Denk (2016). Apart from $M$. lignitum and possibly Decodon gibbosus, typical swamp elements are absent (VU3). D. verticillatus, which is considered the modern analogue of the latter, is an aquatic plant inhabiting stream shores and shallow water at the edges of lakes and swamps (Miyawaki et al., 1994). In the surroundings, outside the influence of flooding, a mixed broad-leaved forest probably developed, with deciduous and evergreen taxa such as deciduous oaks, Podocarpium podocarpum

Table 2. Results derived by IPR Vegetation Analysis (sensu Kovar-Eder et al., 2008; Teodoridis et al., 2011) for the studied fossil assemblages; regarding Metochia, the floristic elements reported by Mantzouka et al. (2015) are also taken into account

\begin{tabular}{|c|c|c|c|c|c|c|c|c|c|c|c|c|}
\hline 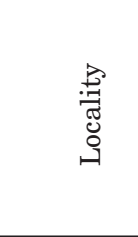 & 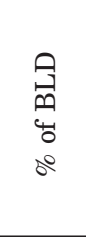 & $\begin{array}{l}\text { 四 } \\
\qquad 0 \\
0 \\
0 \\
0\end{array}$ & 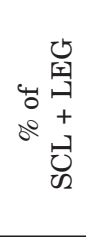 & 宓岕 & 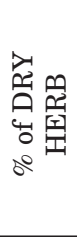 & 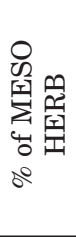 & 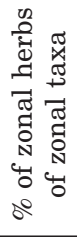 & 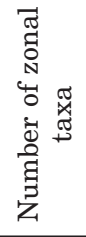 & 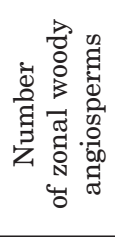 & 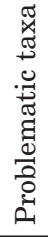 & 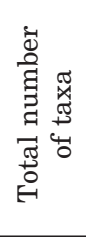 & 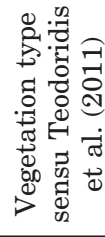 \\
\hline Pitsidia & 61.40 & 12.40 & 26.20 & 0 & 0 & 1.26 & 1.26 & 39.72 & 36.22 & 0 & 52.97 & ShSF \\
\hline Kassanoi & 50.00 & 29.63 & 20.37 & 0 & 0 & 3.33 & 3.33 & 15 & 13.5 & 0 & 23 & ShSF \\
\hline Metochia & 58.62 & 18.97 & 20.69 & 1.72 & 0 & 0 & 0 & 32 & 29 & 0 & 38 & ShSF \\
\hline
\end{tabular}


Table 3. Plant assemblage of Kassanoi, floristic composition

\begin{tabular}{|c|c|c|c|c|}
\hline $\mathrm{Nr}$. & Family & Taxon & Plant part/organ & Frequency $^{*}$ \\
\hline \multicolumn{5}{|c|}{ Polypodiophyta } \\
\hline 1 & fam. indet. & gen. et sp. indet. type 2 & fronds & rare \\
\hline \multicolumn{5}{|c|}{ Gymnospermae } \\
\hline 2 & Cupressaceae & Tetraclinis cf. salicornioides & leafy twigs & rare \\
\hline \multicolumn{5}{|c|}{ Angiospermae } \\
\hline 3 & Lauraceae & Daphnogene polymorpha & leaves & abundant \\
\hline 4 & Fabaceae & Podocarpium podocarpum & leaflets & abundant \\
\hline 5 & Rosaceae & gen. et sp. indet. type 2 & leaves & rare \\
\hline 6 & Rhamnaceae & Berchemia multinervis & leaves & rare \\
\hline 7 & Ulmaceae & Ulmus cf. plurinervia & leaves & common \\
\hline 8 & Fagaceae & Quercus sp. & leaves & rare \\
\hline 9 & Myricaceae & Myrica lignitum & leaves & abundant \\
\hline 10 & \multirow{3}{*}{ Salicaceae } & Salix angusta & leaves & \\
\hline 11 & & ? Salix sp. & leaves & abundant \\
\hline 12 & & Populus latior & leaves & rare \\
\hline 13 & Lythraceae & Decodon gibbosus & leaves & rare \\
\hline 14 & Oleaceae & Fraxinus sp. & leaflets & rare \\
\hline 15 & \multirow{11}{*}{ fam. indet. } & \multirow{11}{*}{$\begin{array}{l}\text { Monocotylophyllum sp. } 6 \\
\text { Monocotylophyllum sp. } 7 \\
\text { Monocotylophyllum sp. } 8 \\
\text { Dicotylophyllum sp. } 14 \\
\text { Dicotylophyllum sp. } 15 \\
\text { Dicotylophyllum sp. } 16 \\
\text { Dicotylophyllum sp. } 17 \\
\text { Dicotylophyllum sp. } 18 \\
\text { Dicotylophyllum sp. } 19 \\
\text { Antholithes } \text { sp. } \\
\text { gen. et sp. indet. }\end{array}$} & \multirow{11}{*}{$\begin{array}{l}\text { leaves } \\
\text { leaves } \\
\text { leaves } \\
\text { leaves } \\
\text { leaves } \\
\text { leaves } \\
\text { leaves } \\
\text { leaves } \\
\text { leaves } \\
\text { flowers } \\
\text { ?fruits }\end{array}$} & \multirow{11}{*}{$\begin{array}{l}\text { rare } \\
\text { rare } \\
\text { rare } \\
\text { rare } \\
\text { abundant } \\
\text { rare } \\
\text { common } \\
\text { rare } \\
\text { rare } \\
\text { rare } \\
\text { rare }\end{array}$} \\
\hline 16 & & & & \\
\hline 17 & & & & \\
\hline 18 & & & & \\
\hline 19 & & & & \\
\hline 20 & & & & \\
\hline 21 & & & & \\
\hline 22 & & & & \\
\hline 23 & & & & \\
\hline 24 & & & & \\
\hline 25 & & & & \\
\hline
\end{tabular}

" rare $1-4$, common $5-15$, abundant $\geq 16$

and D. polymorpha. Berchemia multinervis either represented a climber or was part of the understory. Ulmus cf. plurinervia, Tetraclinis cf. salicornioides, Fraxinus, Rosaceae and Salicaceae could also have been part of this association (VU5).

For Kassanoi the application of IPR Vegetation Analysis is hampered by the limited number of zonal taxa and the poor preservation of the leaf material, which makes it difficult to assign the components. The zonal vegetation type deduced by IPR Vegetation Analysis is subhumid sclerophyllous forest (ShSF) (Tab 2; Appx. 5b).

\section{METOCHIA}

For the palaeoflora of Metochia on Gavdos Island, eight further taxa were identified in this study, enriching the record reported by Mantzouka et al. (2015). (Tab. 4; Appx. 6). Among them are Sabalites, Quercus mediterranea, Ziziphus paradisiaca and a 5-needled pine.

The Metochia assemblage originated in a marine environment supplied by river flooding (Antonarakou, 2001; Tsaparas, 2005). The delta plain possibly was located in the southern parts of central and western Crete (e.g., Meulenkamp et al., 1988; Postma et al., 1993). The occurrence of fishes such as Bregmaceros albyi Sauvage and Lepidopus sp. in the plant-bearing layers indicates a maximum sea depth of $300 \mathrm{~m}$ (Gaudant et al., 2005; Tsaparas, 2005).

Similar to Pitsidia and Kassanoi, application of IPR Vegetation Analysis for the plant assemblage of Metochia indicates a subhumid sclerophyllous forest (ShSF) (Tab. 2; Appx. 5c). Due to differences in scoring some taxa such as Daphnogene and Leguminosites div. sp., our results stand in contrast to those of Mantzouka et al. (2015), who assumed transitional vegetation between broad-leaved deciduous (BLDF) and mixed mesophytic forests (MMF).

\section{THE STUDIED FLORAS IN THE MIOCENE CONTEXT OF CRETE}

Apart from the herein-described floras, two more macro-assemblages - Makrilia in the eastern part of the island (late Tortonian, 
Table 4. Plant assemblage of Metochia, floristic elements identified in this study

\begin{tabular}{|c|c|c|c|c|}
\hline Nr. & Family & Taxon & Plant part/organ & Frequency $^{*}$ \\
\hline \multicolumn{5}{|c|}{ Gymnospermae } \\
\hline 1 & Cupressaceae & Tetraclinis cf. salicornioides & leafy twigs & rare \\
\hline 2 & Pinaceae & Pinus sp. 2, 5-needled, subgen. Strobus & needles & rare \\
\hline \multicolumn{5}{|c|}{ Angiospermae } \\
\hline 3 & \multirow{2}{*}{ Lauraceae } & \multirow{2}{*}{$\begin{array}{l}\text { Daphnogene polymorpha } \\
\text { ?Lindera ovata }\end{array}$} & \multirow{2}{*}{$\begin{array}{l}\text { leaves } \\
\text { leaves }\end{array}$} & \multirow{2}{*}{$\begin{array}{l}\text { rare } \\
\text { rare }\end{array}$} \\
\hline 4 & & & & \\
\hline 5 & Arecaceae & Sabalites sp. & leaves & rare \\
\hline 6 & Fabaceae & ?Leguminosites $\mathrm{sp} .3$ & leaflets & rare \\
\hline 7 & Rhamnaceae & Ziziphus paradisiaca & leaves & rare \\
\hline 8 & \multirow{2}{*}{ Fagaceae } & \multirow{2}{*}{$\begin{array}{l}\text { Quercus mediterranea } \\
\text { Fagus gussonii }\end{array}$} & \multirow{2}{*}{$\begin{array}{l}\text { leaves } \\
\text { leaves }\end{array}$} & \multirow{2}{*}{$\begin{array}{l}\text { rare } \\
\text { common }\end{array}$} \\
\hline 9 & & & & \\
\hline 10 & Myricaceae & Myrica lignitum & leaves & rare \\
\hline 11 & Juglandaceae & Engelhardia orsbergensis & leaflets & rare \\
\hline 12 & Salicaceae & Populus latior & leaves & rare \\
\hline 13 & \multirow{5}{*}{ fam. indet. } & \multirow{5}{*}{$\begin{array}{l}\text { Monocotylophyllum sp. } 9 \\
\text { Monocotylophyllum sp. } 10 \\
\text { Dicotylophyllum sp. } 20 \\
\text { Dicotylophyllum sp. } 21 \\
\text { gen. et sp. indet. }\end{array}$} & \multirow{5}{*}{$\begin{array}{l}\text { leaves } \\
\text { leaves } \\
\text { leaves } \\
\text { leaves } \\
\text { ? fruits }\end{array}$} & \multirow{5}{*}{$\begin{array}{l}\text { rare } \\
\text { rare } \\
\text { rare } \\
\text { rare } \\
\text { rare }\end{array}$} \\
\hline 14 & & & & \\
\hline 15 & & & & \\
\hline 16 & & & & \\
\hline 17 & & & & \\
\hline
\end{tabular}

"rare $1-5$, common $\geq 6$

Sachse, 2004) and Vrysses in western Crete (Messinian, Zidianakis et al., 2007) - have been reported previously (Fig. 1). The Makrilia plant assemblage occurs in a silty layer a few meters thick, being part of alternating series of hemipelagic marls and sand turbiditic layers. In Vrysses the plant-bearing layers comprise marls and marly limestones deposited in a shallow semi-enclosed marine embayment. The present study revises the original floristic lists of these assemblages, taking into account the newly described findings (Velitzelos D. et al., 2014; Zidianakis et al., 2016; Zidianakis, 2018) and a re-examination of the available material (Appx. 7, 8).

Due to their spatial and temporal proximity, the Cretan palaeofloras (Makrilia, Vrysses, Metochia, Pitsidia, Kassanoi) are quite similar floristically. In most of them (except for Kassanoi), Pinaceae, Lauraceae, Fagaceae, Fabaceae, Juglandaceae, Salicaceae and Sapindaceae are well represented in terms of species diversity and abundance (Tab. 5). They share Daphnogene polymorpha, Myrica lignitum, Quercus mediterranea, two-needled Pinus (except for Kassanoi) and Populus latior (except for Makrilia).

The Makrilia and Metochia plant-bearing sediments were deposited in an open marine environment, Vrysses in a shallow semienclosed marine embayment, and Pitsidia and Kassanoi in freshwater reservoirs. For the taphocoenoses of Makrilia and Metochia a more regional character may be assumed; this is expressed by the higher diversity of taxa and smaller leaf size, especially in Makrilia. Pitsidia and Kassanoi seem to depict a more local origin which better expresses the adjacent habitats. In this context, the swampy and riparian elements are better represented in Pitsidia and Kassanoi than the other floras are. The occurrence of zonal broad-leaved taxa and especially beech is more distinct in Makrilia and Metochia, implying a stronger representation of taxa from the hinterland. In Pitsidia the dominant lobed oak Quercus pseudocastanea, which is entirely absent from the other assemblages, is likely related to its local occurrence in the surroundings of the deposition area. Alternatively, this oak may be azonal. Thermophilic elements (e.g. Sabalites, Lauraceae, Asteroxylon, Engelhardia) are more frequent in Makrilia and Metochia. This may be related to the higher floristic diversity of these sites or to a climatic shift towards warmer conditions. Contrary to the other floras, in Vrysses, Tetraclinis is represented by twig fragments of the type $T$. brachyodon, which may be considered more xerophytic than T. salicornioides occurring in the other floras. Apart from T. brachyodon, the dominance of several sclerophyllous elements in Vrysses (e.g. 2-needled pine, Quercus metiderranea, Ziziphus paradisiaca) is evident. 
Table 5. Floristic comparison of the Cretan palaeofloras

\begin{tabular}{|c|c|c|c|c|c|c|}
\hline Nr. & Taxon & Kassanoi & Pitsidia & Metochia & Makrilia & Vrysses \\
\hline \multicolumn{7}{|c|}{ Algae } \\
\hline 1 & Fam. et gen. et sp. indet. - thallus & & + & & & \\
\hline
\end{tabular}

Polypodiophyta

\begin{tabular}{l|l|c|c|c|c|c}
\hline 2 & Equisetum sp. & & & & + & \\
\hline 3 & "Pteris" oeningensis & & ++ & & & \\
\hline 4 & Polypodiophyta fam. et gen. et sp. indet. - frond & $+(1$ type $)$ & $+(1$ type $)$ & & & \\
\hline
\end{tabular}

Gymnospermae

\begin{tabular}{l|l|c|c|c|c|c}
\hline 5 & Tetraclinis salicornioides & cf. + & cf. + & ++ & + & \\
\hline 7 & Tetraclinis brachyodon & & & & & + \\
\hline 8 & Taxodium dubium & & ++ & + & + & \\
\hline 9 & Cupressaceae gen. et sp. indet. - leafy shoot & & & & + & \\
\hline 10 & Pinus pitsidiensis & & +++ & & & + \\
\hline 11 & Pinus sp. - 2-needled fascicles & + & + & + & +++ \\
\hline 12 & Pinus sp. - 5-needled fascicles & & + & + & + & \\
\hline 13 & Cathaya vel Keleteria vel Cedrus sp. - cone scale & & & & cf.+ & \\
\hline 14 & Pinaceae gen. et sp. indet. (not Pinus $)-$ seed & & & & + & \\
\hline
\end{tabular}

Angiospermae

\begin{tabular}{|c|c|c|c|c|c|c|}
\hline 15 & Daphnogene polymorpha & +++ & ++ & ++ & + & + \\
\hline 16 & Laurophyllum sp. & & & +++ & $+(4$ types $)$ & \\
\hline 17 & Lindera ovata & & $?+$ & $?++$ & & \\
\hline 18 & Sassafras sp. - folia & & & $?+$ & & \\
\hline 19 & Lauraceae gen. et sp. indet. & & $?+$ & & & \\
\hline 20 & Cymodocea vel Posidonia sp. - rhizome & & & & ++ & \\
\hline 21 & Ruppia sp. - seed & & & & cf.+ & \\
\hline 22 & Smilax cf. petiolata & & & & + & \\
\hline 23 & Sabalites sp. & & & + & & \\
\hline 24 & Berberis vel Mahonia & & & & cf.+ & \\
\hline 25 & Mahonia sp. & & & & + & \\
\hline 26 & Buxus pliocenica & & & & + & + \\
\hline 25 & Buxus cf. egeriana & & & & + & \\
\hline 27 & Liquidambar europaea & & ++ & & + & \\
\hline 28 & Ampelopsis vel Vitis sp. - seed & & & & cf.+ & \\
\hline 29 & Podocarpium podocarpum & +++ & ++ & & ++ & \\
\hline 30 & Mimosites sp. & & + & & $?+$ & \\
\hline 31 & Leguminosites sp. & & $+(2$ types $)$ & $+(? 5$ types $)$ & $+(? 7$ types $)$ & $+(2$ types $)$ \\
\hline 32 & Leguminosites sp. - seed & & & & cf.+ & \\
\hline 33 & Leguminocarpon sp. & & & $+(1$ type $)$ & $+(1$ type $)$ & \\
\hline 34 & Rosaceae gen. et sp. indet. type 1 - folia & & + & & & \\
\hline 35 & Rosaceae gen. et sp. indet. type $2-$ folia & + & & & & + \\
\hline 36 & "Parrotia" pristina & & & & & $?+$ \\
\hline 37 & Berchemia multinervis & + & & & & \\
\hline 38 & Paliurus tiliifolius & & & + & & \\
\hline 39 & Ziziphus paradisiaca & & & + & + & ++ \\
\hline 40 & Ulmus cf. plurinervia & ++ & + & + & + & \\
\hline 41 & Ulmus sp. - fructus & & + & & + & \\
\hline 42 & Zelkova zelkovifolia & & $?+$ & & + & \\
\hline 43 & Quercus pseudocastanea & & +++ & & & \\
\hline 44 & Quercus kubinyii & & ++ & & $?+$ & \\
\hline 45 & Quercus mediterranea & & + & + & ++ & +++ \\
\hline 46 & Quercus sp. deciduous - folia & + & & & & \\
\hline 47 & Quercus sp. evergreen - folia & & & & & + \\
\hline 48 & Quercus sp. - fructus & & & & + & \\
\hline 49 & Fagus gussonii & & + & +++ & +++ & \\
\hline 50 & Myrica lignitum & +++ & +++ & +++ & ++ & + \\
\hline 51 & Juglans acuminata & & & & & $?+$ \\
\hline 52 & Carya serrifolia & & & & + & \\
\hline 53 & Carya sp. - folia & & ++ & & & \\
\hline
\end{tabular}


Table 5. Continued

\begin{tabular}{|c|c|c|c|c|c|c|}
\hline Nr. & Taxon & Kassanoi & Pitsidia & Metochia & Makrilia & Vrysses \\
\hline 54 & Pterocarya sp. - fructus & & + & & & \\
\hline 55 & Engelhardia orsbergensis & & & ++ & ++ & \\
\hline 56 & Juglans vel Carya sp. - fructus & & & & + & \\
\hline 57 & Juglandaceae gen. et sp. indet. - folia & & + & & & \\
\hline 58 & Alnus gaudinii & & & & cf.+ & \\
\hline 59 & Carpinus sp. - folia & & & $?+$ & ++ & \\
\hline 60 & Carpinus type orientalis - fructus & & & & + & \\
\hline 61 & Betula sp. & & & + & & \\
\hline 62 & Ostrya sp. - folia & & cf.+ & & & \\
\hline 63 & Salix angusta & + & & cf. +++ & & \\
\hline 64 & Salix type purpurea & & & & $?+$ & \\
\hline 65 & Salix sp. - folia & $?+++$ & $+(1$ type $)$ & & $++(1$ type $)$ & $?+(1$ type $)$ \\
\hline 66 & Populus latior & + & + & + & & + \\
\hline 67 & Populus sp. - folia & & + & & & \\
\hline 68 & Populus sp. - fructus & & & & + & \\
\hline 69 & Decodon gibbosus & + & & & & \\
\hline 70 & Sapindus graecus & & & + & & \\
\hline 71 & Acer tricuspidatum & & + & & & \\
\hline 72 & Acer integrilobum and/or A. pseudomonspessulanum & & + & & +++ & +++ \\
\hline 73 & Acer aegopodifolium & & $?+$ & & & \\
\hline 74 & Acer cf. integerrimum & & & & + & + \\
\hline 75 & Acer angustilobum & & & + & + & \\
\hline 76 & Acer sp. - fructus & & $+(2$ types $)$ & & $+(3$ types $)$ & \\
\hline 77 & Toddalia sp. - seed & & & & cf.+ & \\
\hline 78 & Ailanthus pythii & & & + & & \\
\hline 79 & Aquilaria sp. - folia & & & & + & \\
\hline 80 & Tilia sp. - bracts & & & & cf.+ & \\
\hline 81 & Symplocos cf. minutula & & & & $?+$ & \\
\hline 82 & Fraxinus sp. - folia & + & & & & \\
\hline 83 & Fraxinus sp. - fructus & & & & + & \\
\hline 84 & Asterocalyx styriacus & & & & + & \\
\hline 85 & Monocotylophyllum sp. & $+(3$ types $)$ & $+(5$ types $)$ & $+(>2$ types $)$ & ++ & $++(2$ types $)$ \\
\hline 86 & Dicotylophyllum sp. & $+++(6$ types $)$ & $+(13$ types $)$ & $+(8$ types $)$ & $+(20$ types $)$ & $+(12$ types $)$ \\
\hline 87 & Carpolithus sp. & & & & $+(3$ types $)$ & \\
\hline 88 & Antholithes sp. & $+(1$ type $)$ & & & & \\
\hline
\end{tabular}

THE FLORAS OF PITISIDIA, KASSANOI AND METOCHIA IN THE CONTEXT OF VEGETATION DEVELOPMENT IN EUROPE

During the Neogene, North Mediterranean plant ecosystems underwent considerable changes. Humid and thermophilous taxa successively became extinct, and more open landscapes frequently replaced dense forest vegetation. Although typical Mediterranean sclerophyllous plants such as Olea, Ceratonia, Phillyrea and Quercus ilex-type have been documented in the pollen record since the early Miocene, modern-type sclerophyllous Mediterranean ecosystems probably did not develop prior to the beginning of the late Pliocene (Suc et al., 2018). Studies focused on vegetation in South and Southeast Europe show a progressive reduction in thermophilous plants and those with high water requirements during the Miocene, and an increase in (warm-) temperate deciduous and seasonally adapted taxa during the late Miocene and Pliocene (Bertini, 2003; Kovar-Eder et al., 2006; Jiménez-Moreno et al., 2007; Utescher et al., 2007; Ivanov et al., 2011; Suc et al., 2018). Reconstructions based on macrofloras generally indicate forest vegetation in the northern Mediterranean realm for the Tortonian. Palynological records, however, point to more open, sclerophyllous woodlands, especially in northern Spain and central Anatolia (Bertini, 2003; Suc et al., 2018). A more or less droughtadapted vegetation is inferred for the southern part of the Balkan Peninsula (Kovar-Eder et al., 2006; Utescher et al., 2007). Climate reconstructions for European low latitudes 
show conditions too dry for fully humid vegetation, indicating open woodlands (François et al., 2011). Large-mammal data support the presence of open landscape in South Europe since the early late Miocene (Agustí et al., 1999; Fortelius et al., 2006). Note, however, that Denk et al. (2018) reconstructed the vegetation in the Eastern Mediterranean, including Pitsidia, Metochia, Makrilia and Vrysses floras, pointing to mesic forests for the late Miocene. According to Denk et al. (2018) the only exceptions were two pollen floras from the Serres Basin in northern Greece, where, along with a mesic forest, a steppe forest with Pinaceae probably existed.

According to Kovar-Eder et al. (2008), in the time interval around 12-8.5 Ma, the Central European vegetation was characterised by broad-leaved deciduous forests (BLDF) which had replaced early Miocene evergreen forests (BLEF) and mixed mesophytic forests (MMF) as well as Middle Miocene subhumid sclerophyllous forests (ShSF) (Kovar-Eder and Teodoridis, 2018). In the late Miocene and early Pliocene, warmth- and humidity-requiring forests (BLEF and MMF) were still present in some refugia such as the northern Balkan and Italian peninsulas. At the same time, the first records of xeric grasslands were recognised near the northern margin of the Black Sea region (Kovar-Eder et al., 2008). Subhumid sclerophyllous forests (ShSF) were largely restricted to southern parts of Europe. The assignment of Pitsidia, Metochia and Kassanoi to subhumid sclerophyllous forests (ShSF) and the high percentages of the sclerophyllous and legume-like component agree with and confirm the occurrence of this vegetation type in these southern parts of Europe at that time (Tab. 2).

From the Messinian to the middle Zanclean, open woodlands gradually appeared in the central and southern parts of the Italian and Greek peninsulas (Kovar-Eder et al., 2008). IPR Vegetation Analysis of the Messinian floras of Vrysses in Crete and of Vegora in northern Greece resulted in ShSF as the most likely zonal vegetation type. Here the sclerophyllous and legume-like component accounts for 34\% and $26 \%$ at the two sites, respectively (KovarEder et al., 2008; Mantzouka et al., 2015).

\section{CLIMATE PROXIES}

We applied the Coexistence Approach (CA) for the palaeofloras from Pitsidia and Metochia, and the Climate Leaf Analysis Multivariate Program (CLAMP) for Pitsidia. The results of CLAMP for Metochia in Mantzouka et al. (2015) are also taken into consideration. Because of its low diversity, Kassanoi is considered inappropriate for application because the precision of climatic calculations is strongly related to the diversity of taxa (Mosbrugger and Utescher, 1997; Wolfe and Spicer, 1999).

The Coexistence Approach estimates quantitative climatic data from fossil floras using the climate tolerance of the nearest living

Table 6. a. Estimated ranges of 7 palaeoclimatic parameters for Pitsidia and Metochia assessed by the Coexistence Approach (CA): MAT (mean annual temperature), CMT (coldest month mean temperature), WMT (warmest month mean temperature), MAP (mean annual precipitation), MPwet (mean precipitation of the wettest month), MPdry (mean precipitation of the driest month), MPwarm (mean precipitation of the warmest month); b. Estimated ranges for 5 palaeoclimatic parameters for Pitsidia and Metochia assessed by CLAMP (physiognomic and gridded meteorological calibration datasets from 189 sites); MAT (mean annual temperature), WMT (warmest month mean temperature), CMT (coldest month mean temperature), 3-WET (precipitation during 3 consecutive wettest months), 3-DRY (precipitation during 3 consecutive driest months)

\begin{tabular}{|c|c|c|c|c|c|c|c|c|c|c|c|c|c|c|c|}
\hline a & 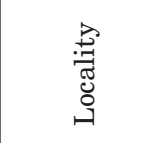 & 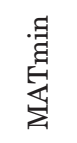 & 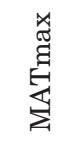 & $\sum_{\Xi}^{\exists}$ & 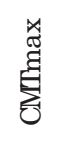 & $\sum_{3}^{\exists}$ & $\sum_{3}^{\not ্]}$ & 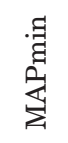 & 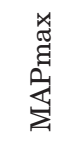 & 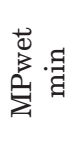 & 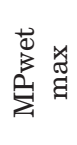 & 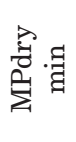 & 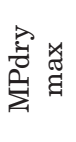 & 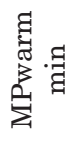 & 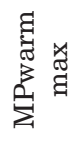 \\
\hline \multirow{2}{*}{$\begin{array}{l}\text { This } \\
\text { study }\end{array}$} & Pitsidia & 13.5 & 18.5 & 2.5 & 7.7 & 23.3 & 28.1 & 897 & 1613 & 167 & 195 & 20 & 64 & 78 & 80 \\
\hline & Metochia & 13.8 & 18.5 & 3.1 & 9.4 & 22.8 & 26.4 & 843 & 1741 & 170 & 195 & 17 & 70 & 73 & 80 \\
\hline \multirow{2}{*}{$\begin{array}{l}\text { Mantzouka } \\
\text { et al., } 2015\end{array}$} & Pitsidia & 13.5 & 19.7 & 2.5 & 9.4 & 19.6 & 27.5 & 897 & 1333 & 160 & 191 & 8 & 56 & 84 & 100 \\
\hline & Metochia & 13.8 & 18.5 & 3.1 & 9.4 & 22.5 & 26.4 & 843 & 1741 & 170 & 195 & 17 & 70 & 73 & 80 \\
\hline
\end{tabular}

\begin{tabular}{l|l|c|c|c|c|c}
\hline \hline $\mathrm{b}$ & Locality & $\begin{array}{c}\text { MAT } \\
\left({ }^{\circ} \mathrm{C}\right)\end{array}$ & $\begin{array}{c}\mathrm{CMT} \\
\left({ }^{\circ} \mathrm{C}\right)\end{array}$ & $\begin{array}{c}\text { WMT } \\
\left({ }^{\circ} \mathrm{C}\right)\end{array}$ & $\begin{array}{c}3 \text {-WET } \\
(\mathrm{mm})\end{array}$ & $\begin{array}{c}3-\mathrm{DRY} \\
(\mathrm{mm})\end{array}$ \\
\hline This study & Pitsidia & 14.7 & 4.0 & 25.9 & 643 & 227 \\
\hline $\begin{array}{l}\text { Mantzouka } \\
\text { et al., 2015 }\end{array}$ & Metochia & 15.2 & 7.5 & 24.9 & 736 & 185 \\
\hline
\end{tabular}


relatives (Mosbrugger and Utescher, 1997; Utescher et al., 2014). The results indicate a warm temperate to subtropical climate for Pitsidia, with mean annual temperature (MAT) between $13.5^{\circ} \mathrm{C}$ and $18.5^{\circ} \mathrm{C}$, warmest month mean temperature (WMT) between $23.3^{\circ} \mathrm{C}$ and $28.1^{\circ} \mathrm{C}$, coldest month mean temperature $(\mathrm{CMT})>2.5^{\circ} \mathrm{C}$ and mean annual precipitation (MAP) of 897-1613 mm (Tab. 6a; Appx. 9a). This climatic analysis implies weak dry-season conditions [mean precipitation of the driest month (MPdry) of 20-64 mm] that may not have coincided with the warmest period of the year, as illustrated by the mean precipitation of the warmest month (MPwarm) of 78-80 mm. CA results for Metochia indicate climatic conditions very close to those of Pitsidia (Tab. 6a; Appx. 9b). The CA results for Pitsidia and Metochia differ only slightly from those derived by Mantzouka et al. (2015), although the floristic spectrum has been enriched considerably by our study.

CLAMP is based on a multivariate statistical technique to quantitatively determine palaeoclimatic parameters, using the leaf physiognomy of woody dicots (Wolfe and Spicer, 1999; Spicer et al., 2009). The application of CLAMP provides estimations for three temperature (MAT, CMT, WMT) and two precipitation variables (3-WET: precipitation during the 3 consecutive wettest months; 3-DRY: precipitation during the 3 consecutive driest months). In both palaeofloras, Pitsidia and Metochia, the estimated CLAMP temperature values fall into the ranges suggested by CA (Tab. 6b; Appx. 10). Regarding precipitation, CLAMP and $\mathrm{CA}$ reconstruct different parameters not allowing direct comparison. Similar to the CA results, CLAMP values indicate seasonality in precipitation, somewhat more pronounced in Metochia.

In the Messara Basin, climatic data derived from shallow-water coral carpets dated as early Tortonian suggest surface sea temperatures above $18^{\circ} \mathrm{C}$ (Brachert et al., 2006). Based on stable isotope records of $\delta^{18} \mathrm{O}$ and $\delta^{13} \mathrm{C}$ in coral skeletons, annual seasonality and interannual fluctuations in sea surface temperature at a time-scale of 2 to 5 years are well expressed. Based on the analysis of non-lattice-bound element concentrations within the coral skeletons (Mertz-Klaus et al., 2009), strong seasonality in precipitation has been proposed, with higher values in the winter.
In a wider climatic context, the mean $\delta^{18} \mathrm{O}$ values from planktonic foraminifera increased gently through the late Miocene until the Pliocene, indicating cooling related to the onset of Arctic glaciation, although several short-time warming events took place (Thiede et al., 1998; Zachos et al., 2001; Winkler et al., 2002; Lear et al., 2003). Climate data for western Eurasia derived from fossil floras and faunas mostly correlated well with the marine records (e.g. Böhme, 2003; Mosbrugger et al., 2005; Bruch et al., 2007; Fauquette et al., 2007; JiménezMoreno, Suc, 2007). According to these data, a general cooling trend took place from the middle to late Miocene in Europe, characterised by a weak increase in both latitudinal and seasonal differentiation for temperature parameters and to a lesser degree in the latitudinal precipitation gradient (Mosbrugger et al., 2005; Bruch et al., 2006, 2007, 2011; Utescher et al., 2011). A warm and humid climate within a Cfa-type climate sensu Köppen-Geiger is documented during the Tortonian, with high latitudes being significantly warmer than today, while the low latitudes ranged at about the same level. Suc et al. (2018) argue that the climatic pattern indicates a north-south climatic gradient during the Tortonian, with increasing temperature and decreasing precipitation.

Using CA, Bruch et al. (2006) estimated MAT of $\sim 14-18^{\circ} \mathrm{C}$, mean temperature of the warmest month (WMT) of $24-27^{\circ} \mathrm{C}$, and mean temperature of the coldest month (CMT) of $2-9^{\circ} \mathrm{C}$ in the Tortonian for Central and South Europe, with warmer values at lower latitudes. The temperature parameters we calculated for Pitsidia and Metochia are consistent with these data.

The precipitation rate in western Eurasia was generally higher during the Tortonian than today, and slightly wetter as compared to the Messinian and the Serravallian (Mosbrugger et al., 2005; Bruch et al., 2006, 2011). MAP mostly exceeded $1000 \mathrm{~mm}$, and according to Mosbrugger et al. (2005) this value did not change drastically until the Pliocene. Bruch et al. $(2006,2011)$ reconstructed MAP for Central and South Europe in the range $~ 750-1400 \mathrm{~mm}$, representing humid conditions. Spatial differentiation is mostly expressed by lower precipitation in the south, especially in southern Greece. The calculated values of MAP coexistence intervals from Pitsidia and Metochia fall into the range estimated by Bruch et al. (2006, 2011). 


\section{ACKNOWLEDGMENTS}

We thank the members of the $\mathrm{PhD}$ thesis examination committee of the first author (Nikolaos Kontopoulos, Katerina Kouli, Maria Panitsa, Maria Geraga and Pavlos Avramidis) for their help and useful remarks. Many thanks to the Natural History Museum of Crete and especially to Charalampos Fassoulas, Curator of the geological and palaeontological collections of the Museum, for support in the excavations and preparation of the material. Eleni Koutsopoulou and Sandra Galanopoulou, SEM technicians in the Scanning Electron Microscopy Laboratory of the University of Patras and the University of Crete, respectively, helped to perform the SEM studies. We also thank Aggelos Agathaggelou for fish teeth identifications, and Torsten Utescher and Vasilis Teodoridis for providing data for the Coexistence Approach and Integrated Plant Record Vegetation Analysis, respectively.

\section{REFERENCES}

Agustí, J., Cabrera, L., Garcés, M., Llenas, M., 1999. Mammal turnover and global climate change in the late Miocene terrestrial record of the Vallès-Penedès Basin (NE Spain). In: Agustí, J., Rook, L., Andrews, P. (eds), Hominoid Evolution and Climatic Change in Europe. Cambridge University Press, Cambridge, pp. 397-412.

Anastasakis, G.C., Dermitzakis, M.D., Triantaphyllou, M.V., 1995. Stratigraphic framework of the Gavdos island Neogene sediments. Newsletters on Stratigraphy 32(1), 1-15.

Antonarakou, A., 2001. Biostratigraphy and paleoenvironmental implications on Miocene sediments of Eastern Mediterranean (Gavdos Island). PhD Thesis, University of Athens, Greece.

Ash, A.W., Ellis, B., Hickey, L.J., Johnson, K.R., Wilf, P., 1999. Manual of leaf architecture: morphological description and categorization of dicotyledons and net-veined monocotyledonous angiosperms. Smithsonian Institution, Washington, D.C.

Belz, G., Mosbrugger, V., 1994. Systematisch-paläoökologische und paläoklimatische Analyse von Blattfloren im Mio/Pliozän der niederrheinishen Bucht (NWDeutschland). Palaeontographica B 233, 19-156.

Benda, L., Meulenkamp, J.E., Zahariasse, W.J., 1974. Biostratigraphic correlations in the Eastern Mediterranean Neogene. 1. Correlation between planktonic foraminiferal, uvigerinid, sporomorphal and mammal zonations of the Cretan and Italian Neogene. Newsletter on Stratigraphy 3, 205-217.

Berger, W., 1953. Jungtertiäre Pflanzenreste aus dem Gebiete der Ägäis (Lemnos, Thessaloniki). Annales Géologiques pays Helléniques 5, 34-65.

Bertini, A., 2003. Palinological evidence of the upper Neogene environments in Italy. In: Kvaček, Z. (ed.), Neogene vegetation and climate reconstructions. Vol 46. Acta Universitatis Carolinae Geologica, Prague, pp. 15-25.
Böhme, M., 2003. The Miocene Climatic Optimum: evidence from ectothermic vertebrates of Central Europe. Palaeogeography, Palaeoclimatology, Palaeoecology 195, 389-401.

Bolge, A.L., 1986. The floral morphology and vascular anatomy of the Hamamelicaceae: subfamily Liquidamaroideae. Annals of the Missouri Botanical Garden 73, 325-347.

Bonneau, M., 1984. Correlation of the Hellenide nappes in the south-east Aegean and their tectonic reconstruction. In: Dixon J.E., Robertson A.H.F. (eds), The geological evolution of the eastern Mediterranean. Geological Society, Special Publ. 17, London, pp. 517-527.

Brachert, T., Reuter, M., Felis, T., Kröger, K.F., Lohmann, G., Michaels, A., Fassoulas, C., 2006. Porites corals from Crete (Greece) open a window into Late Miocene (10 Ma) seasonal and interannual climate variability. Earth and Planetary Science Letters 245(1-2), 81-94.

Braun, A., 1845. Die Tertiär-Flora von Öhningen. Neues Jahrbuch für Geologie und Paläontologie 1845, 164-173.

Bremer, B., Bremer, K., Chase, M.W., Reveal, J.L., Soltis, D.E., Soltis, P.S., Stevens, P.F., (Angiosperm Phylogeny Group) 2003. An update of the Angiosperm Phylogeny Group classification for the orders and families of flowering plants: APG II. Botanical Journal of the Linnean Society 141, 399-436.

Bremer, B., Bremer, K., Chase, M.W., Reveal, J.L., Soltis, D.E., Soltis, P.S., Stevens, P.F., (Angiosperm Phylogeny Group) 2009. An update of the Angiosperm Phylogeny Group classification for the orders and families of flowering plants: APG III. Botanical Journal of the Linnean Society 161, 105-121.

Brongniart, A., 1822. Description des végétaux fossiles du terrain de sédiment supérieur. In: Cuvier, M.M.G., Brongniart, A. (eds), Description géologique dés environs de Paris. Chez G. Dufour et E. d'Ocagne libraires, Paris, pp. 335-402.

Bronn, H.G., 1837-1838. Lethaea geognostica oder Abbildungen und Beschreibungen der für die Gebirgs-Formationen bezeichnendsten Versteinerungen. II. Das Kreide- und Molasse-Gebirge enthaltend. E. Schweizerbar's Verlags-Buchhandlung, Stuttgart.

Bruch, A.A., Utescher, T., Mosbrugger, V., Gabrielyan, I., Ivanov, D.A., 2006. Late Miocene climate in the circum-Alpine realm - a quantitative analysis of terrestrial palaeofloras. Palaeogeography, Palaeoclimatology, Palaeoecology 238, 270-280.

Bruch, A.A., Uhl, G., Mosbrugger, V., 2007. Miocene climate in Europe - Patterns and evolution. - A first synthesis of NECLIME. Palaeogeography, Palaeoclimatology, Palaeoecology 253, 1-7.

Bruch, A.A., Utescher, T., Mosbrugger, V., NECLIME members 2011. Precipitation patterns in the Miocene of Central Europe and the development of continentality. Palaeogeography, Palaeoclimatology, Palaeoecology 304, 202-211. 
Buckland, W., 1836. Geology and mineralogy considered with reference to natural theology. W. Pickering, London.

Butzmann, R., Ioakim, C., Velitzelos, D., Velitzelos, E., 2007a. Cenozoic ferns from Greece - indicators of climate and ecology. In: Elicki, O., Schneider, J.W. (eds), Fossile Ökosysteme. 77. Jahrestagung der Paläontologischen Gesellschaft, Kurzfassungen der Vorträge und Poster, Wissenschaftliche Mitteilungen, Technische Universität Bergakademie Freiberg, Institut für Geologie, Freiberg, pp. 23-24.

Butzmann, R., Velitzelos, D., Velitzelos, E., 2007b. Oligozäne Makroflora aus den tuffitischen Mergeln des westlichen Ergene-Beckens, Tychero, W-Thrakien, NE- Griechenland. In: Elicki, O., Schneider, J.W. (eds), Fossile Ökosysteme. 77. Jahrestagung der Paläontologischen Gesellschaft, Kurzfassungen der Vorträge und Poster, Wissenschaftliche Mitteilungen, Technische Universität Bergakademie Freiberg, Institut für Geologie, Freiberg, pp. 24-25.

Bůžek, Č., 1971. Tertiary flora from the northern part of Petipsy Area (North bohemian basin). Rozpravy Ústředního Ústavu Geologického 36, 1-118.

Chatzaras, V., Xypolias, P., Doutsos, T., 2006. Exhumation of high-pressure rocks under continuous compression: a working hypothesis for the southern Hellenides (Central Crete, Greece). Geological Magazine 143, 859-876.

Chevalier, A., 1901. Monographie des Myricaceés. Mémoires de la Société Nationale des Sciences Naturelles de Cherbourg 32, 85-340.

Christenhusz, M.J.M., Chase, M.W., 2014. Trends and concepts in fern classification. Annals of Botany 113(4), 571-594.

Christenhusz, M.J.M., Reveal, J.L., Farjon, A., Gardner, M.F., Mill, R.R., Chase, M.W., 2011. A new classification and linear sequence of extant gymnosperms. Phytotaxa 19, 55-70.

Creutzburg, N., Seidel, E., 1975. Zum Stand der Geologie des präneogens auf Kreta. Neues Jahrbuch für Geologie und Paläontologie Abh. 149, 363-383.

Czeczott, H., 1951. Środkowo-miocéńska flora Zalesiec koło Wiśniowca. I. Acta Geologica Polonica 2, 349-445.

Denk, T., 2004. Revision of Fagus from the Tertiary of Europe and southwestern Asia and its phylogenetic implications. Documenta Naturae 150, 1-72.

Denk, T., 2016. Palaeoecological interpretation of the late Miocene landscapes and vegetation of northern Greece: a comment to Merceron et al., 2016 (Geobios, doi:10.1016/j.geobios.2016.01.004). Geobios 49, 135-146.

Denk, T., Velitzelos, D., Güner, T.H., Bouchal J.M., Grímsson, F., Grimm, G., 2017. Taxonomy and palaeoecology of two widespread western Eurasian Neogene sclerophyllous oak species: Quercus drymeja Unger and $Q$. mediterranea Unger. Review of Palaeobotany and Palynology 241, 98-128.

Denk, T., Zohner,C.M., Grimm, G.W., Renner, S.S., 2018. Plant fossils reveal major biomes occupied by the late Miocene Old-World Pikermian fauna. Nature Ecology and Evolution 2, 1864-1870.

Dermitzakis, D.M., 1990. Paleogeography, geodynamic processes and event stratigraphy during the late Cenozoic of the Aegean area. Accademia Nazionale de Lincei 85, 263-288.

Dermitzakis, D.M., Papanikolaou, D.J., 1981. Paleogeography and geodynamics of the Aegean region during the Neogene. Annales Géologiques pays Helléniques 30, 245-289.

Dermitzakis, M.D., Velitzelos, E., 1985. Tertiary flora remains from Aegean area: The macroflora from Chios Island (Greece). Rapport Commission International Mer Méditerranée 29(2), 165-166.

Dermitzakis, M.D., Georgiades-Dikeoulia, E., Velitzelos, E., 1985-86. Ecostratigraphic observation on the Messinian deposits of Akropotamos Area (Kavala, N. Greece). Annales Géologiques pays Helléniques 33, 367-376.

Dilcher, D.L., 1974. Approaches to the identification of angiosperm leaf remains. Botanical Review 40(1), $1-157$.

Doweld, A.B., 2017. Nomenclatural novelties and taxonomic changes for extant and fossils Populus (Salicaceae). Kew Bulletin 72, 1-6.

Dransfield, J., Uhl, N.W., Asmussen, C.B., Baker, W.J., Harley M., Lewis, C., 2008. Genera Palmarum: The evolution and classification of palms. The Royal Botanic Gardens, Kew.

Drivaliari, A., 1993. Images polliniques et paléoenvironnements au Néogène supérieur en Méditerranée orientale. Aspects climatiques et paléogéographiques d'un transect latitudinal (de la Roumanie au Delta $\mathrm{du}$ Nil). PhD Thesis, University of Montpellier, France.

Ellis, B., Daly, D.C., Hickey, L.J., Johnson, K.R., Mitchell, J.D., Wilf, P., Wing, S.L., 2009. Manual of leaf architecture. Cornell University Press, New York.

Erdei, B., Kvaček, Z., 1997. A newly recorded collection of the early Miocene flora of Kymi (Greece) previously misinterpreted as the Upper Miocene flora of Tallya (NE Hungary). Annales Historico-naturales Musei Nationalis Hungarici 89, 5-10.

Estenban, L.G., De Palacios, P., 2009. Comparative wood anatomy in Abietoideae (Pinaceae). Botanical Journal of the Linnean Society 160, 184-196.

Ettingshausen, C.V., 1851. Die tertiäre Flora der Umgebungen von Wien. Abhandlungen der Kaiserlich Königlichen Geologischen Reichsanstalt 1, 1-36.

Ettingshausen, C.V., 1852. Fossile Pflanzenreste aus dem trachytischen Sandstein von Heiligenkreuz bei Kremnitz. Abhandlungen der Kaiserlich-Königlichen Geologischen Reichsanstalt 1, 1-14.

Fassoulas, C., 2001. The tectonic development of a Neogene basin at the leading edge of the active European margin: the Heraklion basin, Crete, Greece. Journal of Geodynamics 31, 49-70.

Fauquette, S., Suc, J.-P., Jiménez-Moreno, G., Micheels, A., Jost, A., Favre, E., Bachiri-Taoufiq, N., Bertini, 
A., Clet-Pellerin, M., Diniz, F., Farjanel, G., Feddi, N., Zheng, Z., 2007. Latitudinal climatic gradients in Western European and Mediterranean regions from the Mid-Miocene (c. $15 \mathrm{Ma}$ ) to the Mid-Pliocene (c. 3.5 Ma) as quantified from pollen data. In: Williams, M., Haywood, A., Gregory, J., Schmidt, D.N. (eds), Deep-time perspectives on climate change: Marrying the signal from computer models and biological proxies. Micropaleontol. Soc., Geol. Soc. London, Spec. Publ., London, pp. 481-502.

Ferguson, D.K., 1989. A survey of the Liquidambaroideae (Hamamelidaceae) with a view to elucidating its fossil record. In: Crane, P.R., Blackmore, S. (eds), Evolution, systematics, and fossil history of the Hamamelidae. Vol. 1. Clarendon Press, Oxford, pp. 249-272.

Ferguson, D.K., Pingen, M., Zetter, R., Jofmann, C.C., 1998. Advances in our knowledge of the Miocene plant assemblage from Kreuzau, Germany. Review of Palaeobotany and Palynology 101, 147-177.

Fortelius, M., Eronen, J., Liu, L., Pushkina, D., Tesakov, A., Vislobokova, I., Zhang, Z., 2006. Late Miocene and Pliocene large land mammals and climatic changes in Eurasia. Palaeogeography, Palaeoclimatology, Palaeoecology 238, 219-227.

François, L., Utescher, T., Favre, E., Henrot, A.-J., Warnant, P., Micheels, A., Erdei, B., Suc, J.-P., Cheddadi R., Mosbrugger, V., 2011. Modelling Late Miocene vegetation in Europe: Results of the CARAIB model and comparison with palaeovegetation data. Palaeogeography, Palaeoclimatology, Palaeoecology 304, 359-378.

Fritel, P.H., 1921. Flore aquiranienne d'Oropo (Grèce). Bulletin du Muséum d'Histoire Naturelle 27, 471-476.

Gabrielyan, I., Kovar-Eder, J., 2011. The genus Acer from the lower/middle Pleistocene Sisian Formation, Syunik region, South Armenia. Review of Palaeobotany and Palynology 165, 111-134.

Gaudant, J., Tsaparas, N., Antonarakou, A., Drinia, H., Dernitzakis, M.D., 2005. The Tortonian fish fauna of Gavdos Island (Greece). Comptes Rendus Palevol 4, 687-695.

Goeppert, H.R., 1852. Beiträge zur Tertiärflora Schlesiens. Palaeontographica 2, 260-282.

Goeppert, H.R., 1855. Die tertiäre Flora von Schossnitz in Schlesien. Heyn'sche Buchhandlung, Görlitz.

Gregor, H.J., 1978. Die miozänen Frucht- und SamenFloren der Oberpfälzer Braunkohle. I. Funde aus den sandigen Zwischenmitteln. Palaeontographica B 167(1-3), 8-103.

Gregor, H.J., 1993. Wutzlers Amberbaum - ein neues exotisches Element aus dem Obermiozän von Hambach (Rheinbraun, Koln). Documenta Naturae 80, 1-9.

Güner, H.T., Bouchal, J.M., Köse, N., Göktaş, F., Mayda, S., Denk, T., 2017. Landscape heterogeneity in the Yatağan Basin (southwestern Turkey) during the middle Miocene inferred from plant macrofossils. Palaeontographica B 296(1-6), 113-171.
Hably, L., 2020. The Karpatian (late early Miocene) flora of the Mecsek area. Acta Palaeobotanica 60(1), $51-122$.

Hably, L., Kvaček, Z., 1997. Early Pliocene plant megafossils from the volcanic area in West Hungary. Studia Naturalia 10, 5-151.

Hantke, R., 1954. Die fossile Flora der obermiozänen Oehninger Fundstelle Schrotzburg. Denkschriften der Schweizerischen Naturforschenden Gesellschaft 80, 31-118.

Heer, O., 1853. Übersicht der Tertiärflora der Schweiz. Mittheilungen der Naturforschenden Gesellschaft Zürich 3(7), 88-153.

Heer, O., 1855-1859. Flora Tertiaria Helvetiae - Die tertiäre Flora der Schweiz. Vol. 1-3. J. Wurster et Compagnie, Winterhud.

Heimann, K.O., Junk, W., Braune, K., 1975. Schichtenfolge und Flora des Messinien in Nord-Korfu (Griechenland). Mitteilungen der Bayerischen Staatssammlung für Paläontologie und Historische Geologie 15, 169-177.

Herendeen, P.S., 1992a. Podocarpium podocarpum (A. Braun) Herendeen, comb. n., the correct name for Podogonium knorrii (A. Braun) Heer, nom. illegit. (Leguminosae). Taxon 41, 731-736.

Herendeen, P.S., 1992b. The fossil history of the Leguminosae from the Eocene of southeastern North America. In: Herendeen, P.S., Dilcher, D.L. (eds), Advances in Legume systematics, part 4. The Royal Botanical Gardens, Kew, pp. 85-160.

Hickey, L.J., 1973. Classification of the architecture of dicotyledonous leaves. American Journal of Botany $60,17-33$.

Hilgen, F.J., Krijgsman, W., Langereis, C.G., Lourens, L.J., Santarelli, A., Zachariasse, W.J., 1995. Extending the astronomical polarity time scale into the Miocene. Earth and Planetary Science Letters 136, $495-510$.

Hummel, A., 1983. The Pliocene leaf flora from Ruszow near Zary in Lower Silesia, SW Poland. Prace Muzeum Ziemi 36, 9-104.

Ickert-Bond, S.M., Wen, J., 2006. Phylogeny and biogeography of Altingiaceae: Evidence from combined analysis of five non-coding chloroplast regions. Molecular Phylogenetics and Evolution 39, 512-528.

Ickert-Bond, S.M., Wen, J., 2013. A taxonomic synopsis of Altingiaceae with nine new combinations. Phytokeys $31,21-61$.

Ickert-Bond, S.M., Pigg, K.B., Wen, J., 2005. Comparative infructescence morphology in Liquidambar (Altingiaceae) and its evolutionary significance. American Journal of Botany 92, 1234-1255.

I.G.M.E., 1993. Geological map of Greece, 1:50.000. Institute of Mining and Subsurface Research, Athens.

I.G.M.E., 1994. Geological map of eastern Messara, Crete, 1:25.000. Institute of Mining and Subsurface Research, Athens. 
I.G.M.E., 2002. Geological map of Crete, 1:50.000, sheets: Ano Viannos and Mochos. Institute of Mining and Subsurface Research, Athens.

Iljinskaya, I.A., 1968. Neogenovye flory Zakarpatskoj oblasti USSR. Izdatelstvo Nauka, Leningrand.

Ivanov, D., Utescher, T., Mosbrugger, V., Syabryaj, S., Djordjević-Milutinović, C., Molchanoff, S., 2011. Miocene vegetation and climate dynamics in Eastern and Central Paratethys (Southeastern Europe). Palaeogeography, Palaeoclimatology, Palaeoecology 304, 262-275.

Jähnichen, H., Mai, D.H., Walther, H., 1977. Blätter und Früchte von Engelhardia Lesch. ex Bl. (Juglandaceae) aus dem europäischen Tertiär. Feddes Repertorium 88(5-6), 323-363.

Jähnichen, H., Friedrich, W., Takáč, M., 1984. Engelhardioid leaves and fruits from the European Tertiary. Part II. Tertiary Research 6, 109-134.

Jiménez-Moreno, G., Suc, J.-P., 2007. Middle Miocene latitudinal climatic gradient in Western Europe: Evidence from pollen records. Palaeogeography, Palaeoclimatology, Palaeoecology 253, 224-241.

Jiménez-Moreno, G., Popescu, S.-M., Ivanov, D., Suc, J.-P., 2007. Neogene flora, vegetation and climate dynamics in southeastern Europe and the northeastern Mediterranean. In: Williams, M., Haywood, A.M., Gregory, F.J., Schmidt, D.N. (eds), Deep-Time Perspectives on Climate Change: Marrying the Signal from Computer Models and Biological Proxies. Geological Society London, Special Publications, London, pp. 503-516.

Jones, J.H., Dilcher, D.L., 1980. Investigations of angiosperms from the Eocene of North America: Rhamnus marginatus (Rhamnaceae) reexamined. American Journal of Botany 67, 959-967.

Kleinhölter, K., 1994a. Die neogenen Floren der Peloponnes. Ph.D. Thesis, Münster University, Germany.

Kleinhölter, K., 1994b. Zur stratigraphischen Einstufung der Platana-Formation im Pyrgos- und Zacharo- Becken (West-Peloponnes, Griechenland). Münstersche Forschungen zur Geologie und Palaeontologie 76, 263-270.

Kleinhölter, K., 1995. Oberpliozäne Makrofloren aus dem Bereich des Patras-, Rion- und Korinth-Grabens (Peloponnes und SW-Kontinentalgriechenlnad). Münstersche Forschungen zur Geologie und Palaeontologie 77, 467-478.

Knobloch, E., 1964. Haben Cinnamomum scheuchzeri Heer und Cinnamomum polymorphum (Al. Braun) Heer nomenklatorisch richtige Namen. Neues Jahrbuch für Geologie und Paläontologie, Monatshefte 10, 597-603.

Knobloch, E., Kvaček, Z., 1976. Miozäne Blätterfloren vom Westrand der Böhmischen Masse. Rozpravy Ústředního Ústavu Geologického 42, 1-131.

Knobloch, E., Velitzelos, E., 1986a. Die obermiozäne Flora von Likudi bei Elassona (Thessalien, Griechenland). Documenta Naturae 29, 5-20.
Knobloch, E., Velitzelos, E., 1986b. Die obermiozäne Flora von Prosilion bei Kozani (Sud-Mazedonien, Griechenland). Documenta Naturae 29, 29-33.

Knobloch, E., Velitzelos, E., 1987. New leaf floras in the Neogene of Greece. Věstník Ústředního Ústavu Geologického 62, 157-164.

Kolakovsky, A.A., 1957. Pervoe dopolnenie k kodorskoj pliotsenovoj flore (Meore-Athara). Trudy Sukhumskogo Botanicheskogo Sada 10, 237-318.

Kolakovsky, A.A., 1964. Pliotsenovaja flora Kodora. Sukhumskii Botanicheskii Sad Monografii 1, 1-209.

Kopp, K.O., 1977. Stratigraphic and tectonic sequence of Crete. In: Closs, H., Roeder, H.D., Schmidt, K.E. (eds), Alps, Apennines, Hellenides. Schweizerbart, Stuttgart, pp. 439-442.

Kovar-Eder, J., Krainer, B., 1991. Flora und Sedimentologie der FundsteIle Reith bei Unterstorcha, Bezirk Feldbach in der Steiermark (Kirchberger Schotter, Pannonium C, Miozän). Jahrbuch der Geologischen Bundesanstalt 134(4), 737-771.

Kovar-Eder, J., Kvaček, Z., 2007. The integrated plant record (IPR) to reconstruct Neogene vegetation: the IPR-vegetation analysis. Acta Palaeobotanica 47(2), 391-418.

Kovar-Eder, J. Teodoridis, V., 2018. The Middle Miocene Central European plant record revisited; widespread subhumid sclerophyllous forests indicated. Fossil Imprint 74(1-2), 115-134.

Kovar-Eder, J., Kvaček, Z., Ströbitzer-Hermann, M., 2004. The Miocene Flora of Parschlug (Styria, Austria). Revision and Synthesis. Annalen des Naturhistorischen Museums in Wien 105A, 45-159.

Kovar-Eder, J., Kvaček, Z., Martinetto, E., Roiron, P., 2006. Late Miocene to Early Pliocene vegetation of southern Europe (7-4 Ma) as reflected in the megafossil plant record. Palaeogeography, Palaeoclimatology, Palaeoecology 238, 321-339.

Kovar-Eder, J., Jechorek, H., Kvaček, Z., Parashiv, V., 2008. The integrated plant record: an essential tool for reconstructing Neogene zonal vegetation in Europe. Palaios 23, 97-111.

Kovar-Eder, J., Givulescu, R., Hably, L., Kvaček, Z., Mihajlovic, D., Teslenko, J., Walther, H., Zastawniak, E., 1994. Floristic changes in the areas surrounding the Paratethys during Neogene time. In: Boutler, M.C., Fischer, H.C. (eds), Cenozoic Plants and Climates of the Arctic. NATO ASI ser. I, vol. 27. Springer, Berlin, pp. 347-369.

Krijgsman, W., Hilgen, F.J., Langereis, C.G., 1995. Late Miocene magnetostratigraphy, biostratigraphy and cyclostratigraphy in the Mediterranean. Earth and Planetary Science Letter 136, 475-494.

Krijgsman, W, Hilgen F.J., Langereis, C.G., Zachariasse, W.J., 1994. The age of the Tortonian/Messinian boundary. Earth and Planetary Science Letter $121,533-547$.

Kröger, K.F., 2004. Sedimentary environments and climate change: a case study (late Miocene, central Crete). Ph.D. Thesis, Johannes Gutenberg Universität, Mainz, Germany. 
Kunzmann, L., Kvaček, Z., Mai, D.H., Walther, H., 2009. The genus Taxodium (Cupressaceae) in the Palaeogene and Neogene of Central Europe. Review of Palaeobotany and Palynology 153, 153-183.

Kvaček, Z., 1989. Fosilní Tetraclinis Mast. (Cupressaceae). Časopis Národního Muzea. Rada Přírodovědna 155/86, 45-53.

Kvaček, Z., Sakala, J., 1999. Twig with attached leaves, fruits and seeds of Decodon (Lythraceae) from the Lower Miocene of northern Bohemia, and implications for the dentification of detached leaves and seeds. Review of Palaeobotany and Palynology 107, 201-222.

Kvaček, Z., Walther, H., 1989. Paleobotanical studies in Fagaceae of the European Tertiary. Plant Systematics and Evolution 162, 213-229.

Kvaček, Z., Manchester, S.R., Schorn, H.E., 2000. Cones, seeds, and foliage of Tetraclinis salicornioides (Cupressaceae) from the Oligocene and Miocene of western North America: A geographic extension of the European tertiary species. International Journal of Plant Sciences. 161(2), 331-344.

Kvaček, Z., Velitzelos, D., Velitzelos, E., 2002. Late Miocene Flora of Vegora Macedonia N. Greece. Koralis press, Athens.

Lear, C.H., Elderfield, H., Wilson, P.A., 2003. A Cenozoic seawater $\mathrm{Sr} / \mathrm{Ca}$ record from benthic foraminiferal calcite and its application in determining global weathering fluxes. Earth and Planetary Science Letters 208, 69-84.

Lin, C.P., Huang, J.P., Wu, C.S., Hsu, C.Y., Chaw, S.M., 2010. Comparative chloroplast genomics reveals the evolution of Pinaceae genera and subfamilies. Genome Biology Evolution 2, 504-517.

Lister, G.S., Banga, G., Feenstra, A., 1984. Metamorphic core complexes of cordilleran type in the Cyclades, Aegean Sea, Greece. Geology 12, 221-225.

Mai, D.H., 1994. Two conifers - Tetraclinis Mast. (Cupressaceae) and Metasequoia Miki (Taxodiaceae) - relicts of palaeoclimatic indicators of the past. In: Boutler, M.C., Fischer, H.C. (eds), Cenozoic plants and climates of the Arctic. NATO ASI ser. 1, vol. 27. Springer, Berlin, pp. 199-213.

Mai, D.H., 1995. Tertiäre Vegetationsgeschichte Europas. Gustav Fisher Verl., Jena.

Mai, D.H., 1997. Die oberoligozänen Floren an Nordrand der Sachsischen Lausitz. Palaeontographica B 244, 1-124.

Mai, D.H., 1998. Contribution to the flora of the middle Oligocene Calau Beds in Brandenburg, Germany. Review of Palaeobotany and Palynology 101, 43-70.

Mai, D.H., 1999. Die untermiozänen Floren aus der Spremberger Folge und dem. 2. Flözhorizont in der Lausitz. Teil II, Polycarpicae und Apetale. Palaeontographica B 251(1-3): 1-70.

Mai, D.H., Velitzelos, E., 2007. The fossil flora of Kallithea (Rhodes, Greece) at the Pliocene/Pleistocene boundary. Palaeontographica B 277, 75-99.
Manchester, S.R., 1987. The fossil history of the Juglandaceae. Monographs in Systematic Botany from the Missouri Botanical Garden 21, 1-137.

Mantzouka, D., Kvaček, Z., Teodoridis, V., Utescher, T., Tsaparas, N., Karakitsios, V., 2015. A new late Miocene (Tortonian) flora from Gavdos Island in southernmost Greece evaluated in the context of vegetation and climate in the Eastern Mediterranean. Neues Jahrbuch für Geologie und Paläontologie Abh. 275(1), 47-81.

Maravelis, A., Manutsoglou, E., Konstantopoulos, P., Pantopoulos, G., Makrodimitras, G., Zoumpoulis, E., Zelilidis, A., 2015. Hydrocarbon plays and prospectivity of the Mediterranean ridge. Energy Sources, Part A: Recovery, Utilization, and Environmental Effects 37, 347-355.

Massalongo, A., Scarabelli, E.G., 1859. Studii sulla flora fossile e geologia stratigrafica del Senigalliese. Tip. Galeati I. e figlio, Imola.

Mertz-Kraus, R., Brachert, T.C., Jochum, K.P., Reuter, M., Stoll, B., 2009. LA-ICP-MS analyses on coral growth increments reveal heavy winter rain in the Eastern Mediterranean at 9 Ma. Palaeogeography, Palaeoclimatology, Palaeoecology 273, 25-40.

Meulenkamp, J.E., Sissingh, W., 2003. Tertiary palaeogeography and tectonostratigraphic evolution of the Northern and Southern Peri-Tethys platforms and the intermediate domains of the African-Eurasian convergent plate boundary zone. Palaeogeography, Palaeoclimatology, Palaeoecology 196(1-2), 209-228.

Meulenkamp, J.E., Dermitzakis, M., GeorgiadouDiceoulia, E., Jonkers, H.A., Beoger, H., 1979. Field Guide to the Neogene of Crete. University of Athens, Department of Geology and Palaeontology, ser. A 32, 1-32.

Meulenkamp, J.E., Wortel, M.J.R., Van Wamel, W.A., Spakman, W., Hoogerduynstrating, E., 1988. On the Hellenic subduction zone and the geodynamic evolution of Crete since the late Middle Miocene. Tectonophysics 146, 203-215.

Meulenkamp, J.E., Van der Zwaan, G.J., Van Wamel, W.A. 1994. On late Miocene to recent vertical motions in the Cretan segment of the Hellenic arc. Tectonophysics 234, 53-72.

Miyawaki, A., Iwatsuki, K., Grandtner, M. 1994. Vegetation of Eastern North America. University of Tokyo Press, Tokyo.

Mohr, B., Köhler, J., Adamek-Jacobs, E., 1991. A late Miocene leaf flora from southern Crete (Greece). Pan-european Palaeobotanical Conference, abstract volume, Naturhistorisches Museum Wien, Austria, p. 26.

Mosbrugger, V., Utescher, T. 1997. The coexistence approach - a method for quantitative reconstructions of Tertiary terrestrial palaeoclimate data using plant fossils. Palaeogeography, Palaeoclimatology, Palaeoecology 134, 61-86.

Mosbrugger, V., Utescher, T., Dilcher, D.L., 2005. Cenozoic continental climatic evolution of Central Europe. Proceedings of the National Academy of Sciences 102(42), 14964-14969. 
Mountrakis, D., Tranos, M., Papazachos, C., Thomaidou, E., Karagianni, E., Vamvakaris, D., 2006. Neotectonic and seismological data concerning major active faults and the stress regimes of Northern Greece. In: Robertson, M.N.F., Mountrakis, D. (eds), Tectonic Development of the Eastern Mediterranean Region. Vol. 260. Geological Society, special publ., London, pp. 649-670.

Nikitin, P.A., 1929. The systematic position of the fossil genus Diclidocarya E.M. Reid. Journal of Botany 67, 33-38.

Papanikolaou, D., Vassilakis, E., 2010. Thrust faults and extensional detachment faults in Cretan tectono-stratigraphy: Implications for Middle Miocene extension. Tectonophysics 488, 233-247.

Pingen, M., Ferguson, D.K., Collinson, M.E., 1994, Homalanthus costatus Mai: a new Miocene fruit of Cinnamomum Schaeffer (Lauraceae). Palaeontographica B 232, 155-174.

Postma, G., Hilgen, F.J., Zachariasse, W.J., 1993. Precession-punctuated growth of a late Miocene submarine-fun lobe on Gavdos (Greece). Terra nova 5, 438-444.

Procházka, M., Bůžek Č., 1975. Maple leaves from the Tertiary of North Bohemia. Rozpravy Ústředního Ústavu Geologického 41, 1-86.

Read, R.W., Hickey, L.J., 1972. A revised classification of fossil palm and palm-like leaves. Taxon 21: 129-137.

Reid, E.M., 1920. Recherche sur quelques graines pliocènes du Pont-de-Gail (Cantal). Bulletin de la Société Géologique de France, ser. IV 20, 48-87.

Reveal, J.L., 2012. An outline of a classification scheme for extant flowering plants. Phytoneuron 37, 1-221.

Ring, U., Glodny, J., Will, T., Thomson, S.N., 2010. The Hellenic subduction system: high-pressure metamorphism, exhumation, normal faulting, and largescale extension. Annual Review of Earth and Planetary Sciences 38, 45-76.

Sachse, M., 1997. Die Makrilia-flora (Kreta, Griechenland) - Ein Beitrag zur Neogenen Klima- und Vegetationsgeschichte des östlichen Mittelmeergebietes. $\mathrm{PhD}$ Thesis, ETH, Eidgenössischen Technischen Hochschule Zürich, Switzerland.

Sachse, M., 2004. Die neogene Mega- und Mikroflora von Makrilia auf Kreta und ihre Aussagen zur Klima- und Vegetationgeschichte des östlichen Mittelmeergebietes. Flora Tertiaria Mediterranea 6(12), 1-323.

Sachse, M., Mohr, B.A.R., 1996. Eine obermiozäne Makro- and Mikroflora aus Südkreta (Griechenland), und deren paläoklimatische InterpretationVorläufige Betrachtungen. Neues Jahrbuch für Geologie und Paläontologie Abh. 200, 149-182.

Sachse, M., Mohr, B.A.R., Suc, J.P., 1999. The Makrilia flora. A contribution to the Neogene history of the climate and vegetation of the Eastern Mediterranean. Acta Palaeobotanica suppl. 2, 365-372.
Saporta, G., 1865. Études sur la végétation du Sud-Est de la France à l'époque tertiairia deuxième partie III. Annales des Sciences Naturelles, Botanique 5, $5-152$.

Saporta, G., 1873. Examen critique d'une collection de plants fossiles de Coumi (Eubée). Annales scientifiques de l'École normale supérieure 2, 325-352.

Schimani, V., Schneider, H., 1993-1995. Die Pflanzenfossilien des Burdigal der Mittel-Hellenischen Senke im Gebiet Nordöstlich von Trikala. Annales Géologiques pays Helléniques 36, 467-476.

Seidel, E., Kreuzer, H., Harre, W., 1982. A late Oligocene/early Miocene high pressure belt in the External Hellinides. Geologisches Jahrbuch 23, 165-206.

Sen, S., Valet, J.-P., Ioakim, C., 1986. Magnetostratigraphy and biostratigraphy of the Neogene deposits of Kastellios Hill (Central Crete, Greece). Palaeogeography, Palaeoclimatology, Palaeoecology 53, 321-334.

Simonelli, V., 1894. Appunti sopra i terreni neogenici e quarternari dell' isola di Candia. Atti della reale Accademia dei Lincei 5, 265-268.

Spicer, R.A., Valdes, P.J., Spicer, T.E.V., Craggs, H.J., Srivastava, G., Mehrotra, R.C., Yang, J., 2009. New Developments in CLAMP: Calibration using global gridded meteorological data. Palaeogeography, Palaeoclimatology, Palaeoecology 283, 91-98.

Sternberg, K.V., 1823. Versuch einer geognostisch botanischen Darstellung der Flora der Vorwelt. E. Brenck's Witwe, Regensburg.

Ströbitzer-Hermann, M., 2002. Systematik, Variabilität, regionale und stratigraphische Verbreitung sowie Ökologie der Gattung Acer L. in Mitteleuropa vom Oligo- bis ins Pliozän. Ph.D. Thesis, Universität Wien, Austria.

Suc, J.-P., Popescu, S.-M., Fauquette, S., Bessedik, M., Jiménez-Moreno, G., Bachiri-Taoufiq, N., Zheng, Z., Médail, F., Klotz, S., 2018. Reconstruction of Mediterranean flora, vegetation and climate for the last 23 million years based on an extensive pollen dataset. Ecologia mediterranea, Faculté des sciences et techniques de St Jérôme, Institut méditerranéen d'écologie et de paléoécologie 44(2), 53-85.

Teller, F., 1880. Geologische Beobachtungen auf der Insel Chios. Denkschriften der Kaiserlichen Akademie der Wissenschaften Mathematisch-Naturwissenschaftliche Klasse 40, 340-356.

ten Veen, J.H., Postma, G., 1999. Neogene tectonics and basin fill patterns in the Hellenic outer-arc (Crete, Greece). Basin Research 11, 223-241.

Teodoridis, V., Kovar-Eder, J., Mazouch, P., 2011. Integrated plant record (IPR) vegetation analysis applied to modern vegetation in south China and Japan. Palaios 26, 623-638.

Thiede, J., Winkler, A., Wolfwelling, T., Eldholm, O., Myhre, A.M., Baumann, K.H., Henrich, R., Stein, R., 1998. Late Cenozoic history of the polar North Atlantic - results from ocean drilling. Quaternary Science Reviews 17, 185-208. 
Tsaparas, N., 2005. Contribution in the history of sedimentation of the marine formations from the Late Cenozoic of Gavdos Island. PhD Thesis, University of Athens, Greece.

Unger, F., 1841-1847. Chloris protogaea: Beiträge zur Vorwelt. W. Engelmann, Leipzig.

Unger, F., 1850a. Genera et species plantarum fossilium. W. Braumüller, Wien.

Unger, F., 1850b. Die fossile Flora von Sotzka. Denkschriften der Kaiserlichen Akademie der Wissenschaften Mathematisch-Naturwissenschaftliche Klasse 2, 127-197.

Unger, F., 1862. Wissenschaftliche Ergebnisse einer Reise in Griechenland und in den ionischen Inseln. W. Braumüller, Wien.

Unger, F., 1867. Die fossile Flora von Kumi auf der Insel Euboea. Denkschriften der Kaiserlichen Akademie der Wissenschaften Mathematisch-Naturwissenschaftliche Klasse 27, 27-87.

Utescher, T., Mosbrugger, V., 2015. The Palaeoflora Database. Available from: http://www.palaeoflora. de. Accessed February 2018.

Utescher, T., Erdei, B., François, l., Mosbrugger, V., 2007. Tree diversity in the Miocene forests of Western Eurasia. Palaeogeography, Palaeoclimatology, Palaeoecology 253, 226-250.

Utescher, T., Bruch, A.A., Micheels, A., Mosbrugger, V., Popova, S., 2011. Cenozoic climate gradients in Eurasia - a palaeo-perspective on future climate change? Palaeogeography, Palaeoclimatology, Palaeoecology 304, 351-358.

Utescher, T., Bruch, A.A., Erdei, B., François, L., Ivanov, D., Jacques, F.M.B., Kern, A.K., Liu, Y.C., Mosbrugger, V., Spicer, R.A., 2014. The Coexistence Approach - Theoretical background and practical considerations of using plant fossil for climate quantification. Palaeogeography, Palaeoclimatology, Palaeoecology 410, 58-73.

Vafidis, A., Andronikidis, N., Economou, N., Panagopoulos, G., Zelilidis, A., Manoutsoglou, E., 2012. Reprocessing and interpretation of seismic reflection data at Messara Basin, Crete, Greece. Journal of the Balkan Geophysical Society 15, 31-40.

Van der Weerd, A., 1983. Palynology of some Upper Miocene and Pliocene formations in Greece. Geologisches Jahrbuch Reihe B 48, 3-63.

van Hinsbergen, D.J.J., Meulenkamp, J.E., 2006. Neogene supradetachment basin development on Crete (Greece) during exhumation of the South Aegean core complex. Basin Research 18, 103-124.

Velitzelos, D., Bouchal, J.M., Denk, T., 2014. Review of the Cenozoic floras and vegetation of Greece. Review of Palaeobotany and Palynology 204, 56-117.

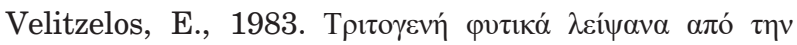

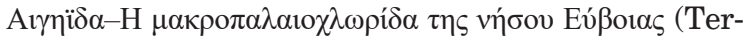
tiary plant remains from Aegeis-The macroflora of Euboea Island). Evia Archive Studies 25, 281-288 [in Greek].
Velitzelos, E., 1993. Neue paläofloristische Daten zu känophytischen Floren Griechenlands. Documenta Naturae 78, 1-17.

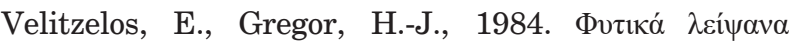

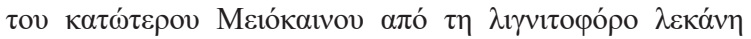

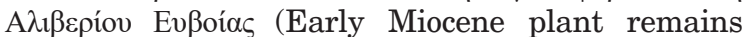
from the lignite-bearing Aliveri basin, Euboea). Evia Archive Studies 25, 184-191 [in Greek].

Velitzelos, E., Gregor, H.-J., 1990. Some aspects of the Neogene floral history in Greece. Review Palaeobotany and Palynology 62, 291-307.

Velitzelos, E., Knobloch, E., 1986. Die pliozäne Flora von Skoura bei Sparta auf dem Peloponnes (Griechenland). Documenta Naturae 29(1), 21-28.

Velitzelos, E., Kvaček, Z., 1999. Review of the Late Miocene flora of Vegora, Western Macedonia, Greece. Acta Palaeobotanica suppl. 2, 419-427.

Velitzelos, E., Petrescu, I., 1981. Seltene pflanzliche Fossilien aus dem Braunkohlenbecken von Vegora. Annales Géologiques pays Helléniques 30, 767-777.

Velitzelos, E., Schneider, H.E., 1977. Jungtetiäre Pflanzenfunde aus dem Becken von Vegora in WestMazedonien (Griechenland). Annles Musei Goulandris 3, 173-180.

Velitzelos, E., Bůžek, C., Kvaček, Z., 1992. Contribution to the Lower Miocene flora of Aliveri (Island of Evia, Greece). Documenta Naturae 74, 10-25.

Velitzelos, E., Kvaček, Z., Velitzelos, D., 1999.

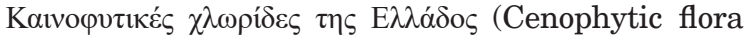
of Greece). Proceedings of the International Symposium for protected natural areas and environmental education, Sigri, Lesbos, Greece, pp. 460-467 [in Greek].

Velitzelos, E., Kvaček, Z., Denk, T., Velitzelos, D., 2002a. Palaeontology and palaeobotany. In: Velitzelos D. (ed.), Field guide to the Neogene of the Island of Evia - Early Miocene flora of Kymi, 6th Europ. Palaeobotany-Palynology Conference, Athens, pp. 10-61.

Velitzelos, E., Velitzelos, D., Papagiannis, G., Dia-

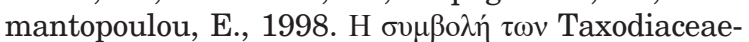

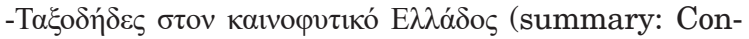
tribution of Taxodiaceae in the Greek Cenophytic). Proceedings of 3rd international symposium on protected areas managment and natural monuments, Molyvos, Lesbos, Greece, pp. 272-291.

Velitzelos, E., Teodoridis, V., Kvaček, Z., Velitzelos, D. 2002b. Plio-Pleistocene flora from Archangelos, Rhodes Island, Greece. 6th Europ. PalaeobotanyPalynology Conference, abstracts volume, Athens, pp. 184-185.

Vicente, J.C., 1970. Étude géologique de ile de Gavdos (Grèce), la plus meridional de l'Europe. Bulletin de la Société Géologique de France 7(12), 481-495.

Walther, H., 1972. Studien über tertiäre Acer Miltteleuropas. Abhandlungen des Staatlichen Museums für Mineralogie und Geologie 19, 1-309.

Walther, H., Zastawniak, E., 1991. Fagaceae from Sośnica and Malczyce (near Wrocław, Poland). A revision of original materials by Goeppert 1852 
and 1855 and a study of new collections. Acta Palaeobotanica 31, 153-199.

Wang, Q., Dilcher, D.L., Lott, T.A., 2007. Podocarpium A. Braun ex Stizenberger 1851 from the middle Miocene of Eastern China, and its palaeoecology and biogeography. Acta Palaeobotanica 47(1), 237-251.

Wang, Y-F, Manchester, S.R., 2000. Chaneya, a new genus of winged fruit from the Tertiary of North America and eastern Asia. International Journal of Plant Sciences 161(1), 167-178.

Watson, L., Dallwitz, M.J., 2008. The families of gymnosperm, DELTA database. Available from: http:// www.delta-intkey.com/gymno/index.htm. Accessed Mai 2018.

Weber, O. 1852. Die Tertiärflora der Niederrheinischen Braunkholenformation. Palaeontographica 2, 3-122.

Wessel, P., Weber, O., 1855. Neuer Beitrag zur Tertiärflora der niederrheinischen Braunkohlenformation. Palaeontographica 4, 111-130.

Winkler, D.W., Dunn, P.O., McCulloch, C.E., 2002. Predicting the effects of climate change on avian lifehistory traits. Proceedings of the National Academy of Sciences of the USA 99, 13595-13599.

Wolfe, J.A., Spicer, R.A., 1999. Fossil Leaf Character States: Multivariate Analysis. In: Jones, T.P., Rowe, N.P. (eds), Fossil Plants and Spores: Modern Techniques. Geological Society, London, pp. 233-239.

Wolfe, J.A., Tanai, T., 1987. Systematics, phylogeny, and distribution of Acer (maples) in the Cenozoic of Western North America. Journal of the Faculty of Sciences Hokkaido University 22(1), 1-246.

Worobiec, G., 2003. New fossil floras from Neogene deposits in the Bełchatów Mine. Acta Palaeobotanica suppl. 3, 3-133.

Yang, J., Spicer, R.A., Spicer, T.E.V., Li, C-S., 2011. 'CLAMP' Online: a new web-based palaeoclimate tool and its application to the terrestrial Paleogene and Neogene of North America. Palaeobiodiversity and Palaeoenvironments 91, 163-183.

Young, D.J., Watson, L., 1969. Softwood structure and the classification of conifers. New Phytol. 68, 427-432.
Zachariasse, W.J., 1975. Planktonic foraminiferal biostratigraphy of the Late Neogene of Crete (Greece). Utrecht Micropaleontological Bulletins 11, 1-171.

Zachariasse, W.J., van Hinsbergen, D.J.J., Fortuin, A.R., 2011. Formation and fragmentation of a late Miocene supradetachment basin in central Crete: implications for exhumation mechanisms of highpressure rocks in the Aegean forearc. Basin Research 23(6), 678-701.

Zachos, J., Pagani, M., Sloan, L., Thomas, E., Billups, K., 2001. Trends, rhythms, and aberrations in global climate $65 \mathrm{Ma}$ to present. Science 292, 686-693.

Zelilidis, A., Tserolas, P., Chamilaki, E., Pasadakis, N., Kostopoulou, S., Maravelis, A.G., 2016. Hydrocarbon prospectivity in the Hellenic trench system: organic geochemistry and source rock potential of upper Miocene-lower Pliocene successions in the eastern Crete Island, Greece. International Journal of Earth Sciences 105, 1859-1878.

Zidianakis, G., Mohr, B.A.R., Fassoulas, C., 2007. A Late Miocene leaf assemblage from Vrysses, western Crete, Greece, and its paleoenvironmental and paleoclimatic interpretation. Geodiversitas 29(3), 351-377.

Zidianakis, G., Iliopoulos, G., Fassoulas, C., 2010. A new late Miocene plant assemblage from Messara Basin (Crete, Greece). Bulletin of the Geological Society of Greece 63, 781-792.

Zidianakis, G., Iliopoulos, G., Zelilidis, A., Kovar-Eder, J., 2015. Myrica from the plant assemblage of Pitsidia (Crete, Late Miocene): putting the puzzle together. Palaeontographica B 293, 149-171.

Zidianakis, G., Iliopoulos, G., Zelilidis, A., Kovar-Eder, J., 2016. Pinus remains from the Pitsidia plant assemblage document costal pine forests in southern Crete during the Late Miocene. Review of Palaeobotany and Palynology 235, 11-30.

Zidianakis, G., Iliopoulos, G., Zelilidis, A., KovarEder, J., 2020. Evidences of plant-arthropod interaction in the fossil assemblage from Pitsidia (Messara Basin, Crete, Greece, Upper Miocene). Neues Jahrbuch für Geologie und Paläontologie 295(2), 1-15. 
Appendix 1. Simplified geological map of Crete and Gavdos Islands, showing the localities referred to in the text (modified from Krijgsman et al., 1994)

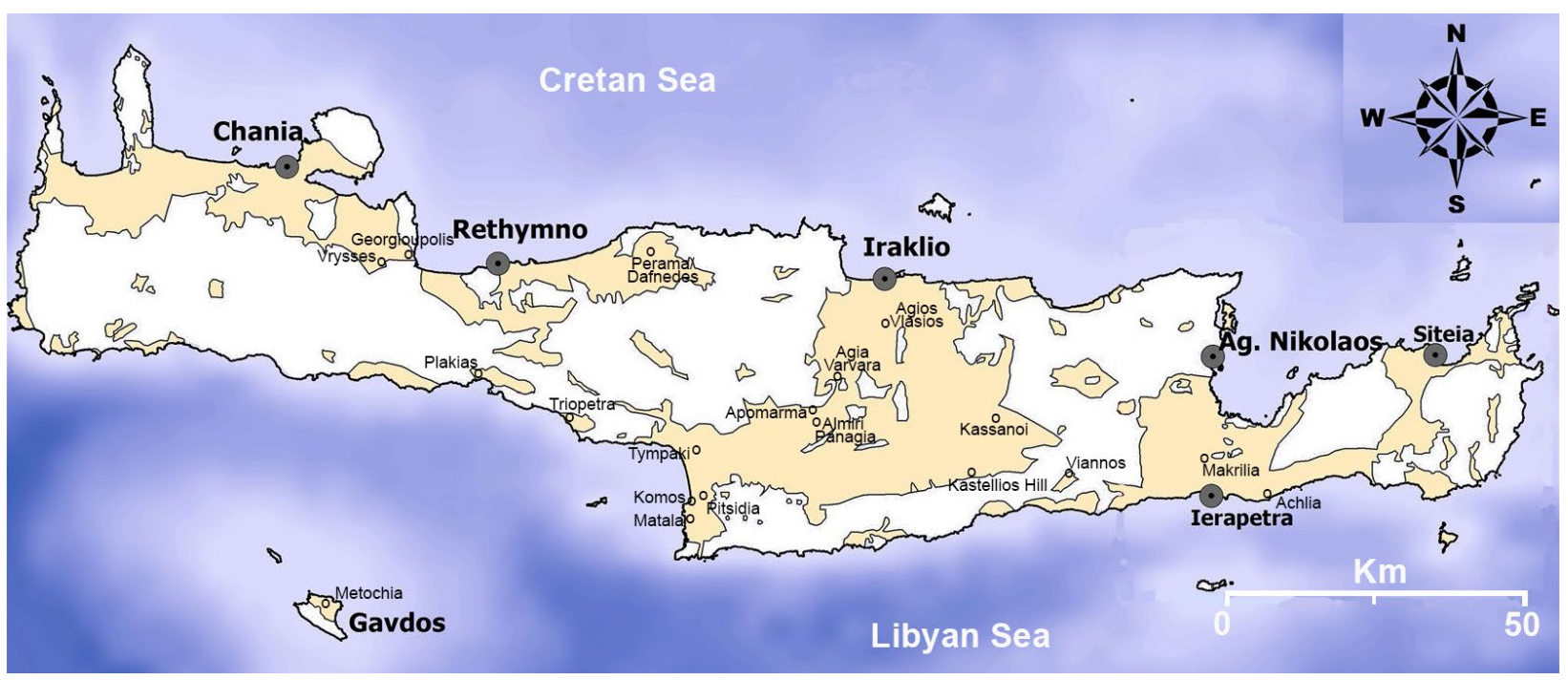

Appendix 2. Pitsidia, collection numbers for defoliated long shoots and wood fragments

Fragments of defoliated long shoots

Material: Nrs 31.4.2.812aopi; 31.4.2.812opii; 31.4.2.819ai,bi; 31.4.2.835; 31.4.2.847; 31.4.2.927; 31.4.2.940; 31.4.2.952; 31.4.2.1042; 31.4.2.1097; 31.4.2.1098; 31.4.2.1119; 31.4.2.1163,1158a,b; 31.4.2.1182aii; 31.4.2.1187; 31.4.2.1193ii; 31.4.2.1202,1185op; 31.4.2.1246; 31.4.2.1297; 31.4.2.1301ii; 31.4.2.1476; 31.4.2.1479; 31.4.2.1501a,b; 31.4.2.1510; 31.4.2.1516; 31.4.2.1637,1635aiii; 31.4.2.1648opi; 31.4.2.1708,1698; 31.4.2.1725; 31.4.2.1729ii; 31.4.2.1751i; 31.4.2.1751op; 31.4.2.1782; 31.4.2.1792; 31.4.2.1804; 31.4.2.1806; 31.4.2.1839,1807; 31.4.2.1871a,b; 31.4.2.1881; 31.4.2.1924; 31.4.2.1928ii; 31.4.2.2017i; 31.4.2.2084; 31.4.2.2098; 31.4.2.2169; 31.4.2.2180; 31.4.2.2185ii; 31.4.2.2188; 31.4.2.2199; 31.4.2.2215; 31.4.2.2270; 31.4.2.2283i; 31.4.2.2333; 31.4.2.2395; 31.4.2.2451; 31.4.2.2489bop; 31.4.2.2500; 31.4.2.2535; 31.4.2.2567; 31.4.2.2575; 31.4.2.2593; 31.4.2.2618ai,bi; 31.4.2.2632i; 31.4.2.2658a,b; 31.4.2.2666; 31.4.2.2702; 31.4.2.2712a,b; 31.4.2.2778; 31.4.2.2792; 31.4.2.2816; 31.4.2.2856; 31.4.2.2862; 31.4.2.2865; 31.4.2.2943iii; 31.4.2.2972i; 31.4.2.2989; 31.4.2.3004i; 31.4.2.3022; 31.4.2.3030aopii; 31.4.2.3035ii; 31.4.2.3039; 31.4.2.3063aop; 31.4.2.3065bii; 31.4.2.3066a,b; 31.4.2.3067bii; 31.4.2.3070; 31.4.2.3104op; 31.4.2.3109; 31.4.2.3112; 31.4.2.3115ai; 31.4.2.3128ai,bi; 31.4.2.3139ai,bi; 31.4.2.3139aii; 31.4.2.3139aiii; 31.4.2.3146bii; 31.4.2.3150bopii; 31.4.2.3161; 31.4.2.3162; 31.4.2.3163aii; 31.4.2.3168; 31.4.2.3169a,b; 31.4.2.3169a,bii; 31.4.2.3174ii; 31.4.2.3198iii; 31.4.2.3216; 31.4.2.3219; 31.4.2.3238i; 31.4.2.3238iil 31.4.2.3238iii; 31.4.2.3247ii; 31.4.2.3295; 31.4.2.3306opi; 31.4.2.3338i; 31.4.2.3345iii; 31.4.2.3401; 31.4.2.3449a,b; 31.4.2.3452v; 31.4.2.3458a,bi; 31.4.2.3461; 31.4.2.3483; 31.4.2.3484; 31.4.2.3496aopii; 31.4.2.3500op; 31.4.2.3504ii; 31.4.2.3526a,b; 31.4.2.3533ii; 31.4.2.3539; 31.4.2.3543bopv; 31.4.2.3543bopvi; 31.4.2.3560op; 31.4.2.3573ai,b; 31.4.2.3581; 31.4.2.3584a,b; 31.4.2.3590aii; 31.4.2.3602; 31.4.2.3613; 31.4.2.3621bii; 31.4.2.3622; 31.4.2.3625; 31.4.2.3627bop; 31.4.2.3627c; 31.4.2.3629i; 31.4.2.3633; 31.4.2.3635ii; 31.4.2.3645; 31.4.2.3658; 31.4.2.3673; 31.4.2.3682; 31.4.2.3684; 31.4.2.3701iii; 31.4.2.3706opii; 31.4.2.3707aii,bii; 31.4.2.3710ai,bi; 31.4.2.3716ii; 31.4.2.3732aii,bii; 31.4.2.3736aiii; 31.4.2.3740b; 31.4.2.3741aii,biv; 31.4.2.3744bopii; 31.4.2.3744bopiii; 31.4.2.3750,3748aop; 31.4.2.3751; 31.4.2.3753; 31.4.2.3765a,b; 31.4.2.3769; 31.4.2.3772i; 31.4.2.3774; 31.4.2.3776; 31.4.2.3780; 31.4.2.3781ii; 31.4.2.3797; 31.4.2.3806aopii; 31.4.2.3810i; 31.4.2.3811opiii; 31.4.2.3819; 31.4.2.3822; 31.4.2.3843; 31.4.2.3847i; 31.4.2.3854; 31.4.2.3855; 31.4.2.3863i; 31.4.2.3863ii; 31.4.2.3893; 31.4.2.3894a,b; 31.4.2.3897; 31.4.2.3904aii,bii; 31.4.2.3914iii; 31.4.2.3917ii; 31.4.2.3924i; 31.4.2.3924ii; 31.4.2.3953a,b; 31.4.2.3984i; 31.4.2.3989; 31.4.2.3994ii; 31.4.2.3997aopi; 31.4.2.4003i; 31.4.2.4004i; 31.4.2.4012a,b; 31.4.2.4021i; 31.4.2.4030i; 31.4.2.4031i; 31.4.2.4044iii; 31.4.2.4051ii; 31.4.2.4053; 31.4.2.4063aii,bii; 31.4.2.4068i; 31.4.2.4083bopii; 31.4.2.4115; 31.4.2.4116; 31.4.2.4125; 31.4.2.4169; 31.4.2.4170; 31.4.2.4221; 31.4.2.4235i; 31.4.2.4240ii; 31.4.2.4240iii; 31.4.2.4241; 31.4.2.4256ii; 31.4.2.4262; 31.4.2.4263ii; 31.4.2.4269; 31.4.2.4276; 31.4.2.4281; 31.4.2.4309ii; 31.4.2.4339bii; 31.4.2.4347aii,bii; 31.4.2.4357; 31.4.2.4393bii; 31.4.2.4411iii; 31.4.2.4418; 31.4.2.4421bii; 31.4.2.4433aii; 31.4.2.4434; 31.4.2.4440; 31.4.2.4469a,b; 31.4.2.4499ii; 31.4.2.4500i; 31.4.2.4501; 31.4.2.4538aiv; 31.4.2.4539aopii; 31.4.2.4562aii,bii; 31.4.2.4572ii; 31.4.2.4575; 31.4.2.4581i; 31.4.2.4602i; 31.4.2.4606av,bv; 31.4.2.4610; 31.4.2.4614; 31.4.2.4616; 31.4.2.4641ai; 31.4.2.4696aiii,biii; 31.4.2.4739ai,bi; 31.4.2.4754; 31.4.2.4758a,b; 31.4.2.4771; 31.4.2.4779a,b; 31.4.2.4827ii; 31.4.2.4851ai,bi; 31.4.2.4874; 31.4.2.4958; 31.4.2.4978a,b; 31.4.2.4981aiii; 31.4.2.4984; 31.4.2.4986; 31.4.2.5005; 31.4.2.5013; 31.4.2.5066op; 31.4.2.5093; 31.4.2.5094a,b; 31.4.2.5097opii; 31.4.2.5138; 31.4.2.5200; 31.4.2.5231op; 31.4.2.5233ii; 31.4.2.5264; 31.4.2.5292; 31.4.2.5293; 31.4.2.5358biii; 31.4.2.5361aii; 31.4.2.5361b; 31.4.2.5362ai; 31.4.2.5373a,b; 31.4.2.5404; 31.4.2.5466aopi; 31.4.2.5466aopii; 31.4.2.5468; 31.4.2.5496ii; 31.4.2.5514; 31.4.2.5575; 31.4.2.5599; 31.4.2.5607; 31.4.2.5635; 31.4.2.5643i; 31.4.2.5649a,b; 31.4.2.5657; 31.4.2.5676opii; 31.4.2.5703ii; 31.4.2.5720; 31.4.2.5725; 31.4.2.5730; 31.4.2.5765; 31.4.2.5768i; 31.4.2.5770; 31.4.2.5806bopi; 31.4.2.5815aopi,5824; 31.4.2.5831; 31.4.2.5884aii,bii; 31.4.2.5890av,bv; 31.4.2.5928ai,bi; 31.4.2.5935aiii; 31.4.2.5962i; 31.4.2.5966; 31.4.2.5974ii; 31.4.2.5985; 31.4.2.6067aii; 31.4.2.6067aiv; 


\section{Appendix 2. Continued}

31.4.2.6068opi; 31.4.2.6185ai,bi; 31.4.2.6186i; 31.4.2.6186ii; 31.4.2.6189aii; 31.4.2.6203; 31.4.2.6232op; 31.4.2.6271; 31.4.2.6276i; 31.4.2.6277aii; 31.4.2.6277aiii; 31.4.2.6278i; 31.4.2.6283opi; 31.4.2.6287; 31.4.2.6290; 31.4.2.6308; 31.4.2.6325aiii; 31.4.2.6326; 31.4.2.6345iii; 31.4.2.6369; 31.4.2.6378; 31.4.2.6389a,b; 31.4.2.6447ii; 31.4.2.6473i; 31.4.2.6479opi; 31.4.2.6513; 31.4.2.6516; 31.4.2.6532ii; 31.4.2.6556aop; 31.4.2.6562,6556aop; 31.4.2.6567opi; 31.4.2.6584; 31.4.2.6589; 31.4.2.6593; 31.4.2.6605; 31.4.2.6626op; 31.4.2.6669; 31.4.2.6679; 31.4.2.6706i; 31.4.2.6706ii; 31.4.2.6723; 31.4.2.6729; 31.4.2.6731; 31.4.2.6765op; 31.4.2.6772op; 31.4.2.6780op; 31.4.2.6834; 31.4.2.6834op; 31.4.2.6835; 31.4.2.6836; 31.4.2.6837; 31.4.2.6850; 31.4.2.6856; 31.4.2.6869op; 31.4.2.6899,6866aop; 31.4.2.6948aiv; 31.4.2.6951aop; 31.4.2.2842a,b; 31.4.2.8019; 31.4.2.8033; 31.4.2.8056; 31.4.2.8057; 31.4.2.8061,8079; 31.4.2.8062,8063i; 31.4.2.8072; 31.4.2.8075; 31.4.2.8076; 31.4.2.8077,8058; 31.4.2.8083; 31.4.2.8166a,b; 31.4.2.8167iii.

\section{Wood fragments}

Material: Nrs 31.4.2.818bii; 31.4.2.1056; 31.4.2.1058ii; 31.4.2.1080a,b; 31.4.2.1269op; 31.4.2.1270; 31.4.2.1290ii; 31.4.2.1311ii; 31.4.2.1341ii; 31.4.2.1356; 31.4.2.1361ii; 31.4.2.1590; 31.4.2.1591vi; 31.4.2.1835; 31.4.2.1917v; 31.4.2.1917vi; 31.4.2.1950; 31.4.2.1951; 31.4.2.2000aii,bii; 31.4.2.2020i; 31.4.2.2037; 31.4.2.2078i; 31.4.2.2194; 31.4.2.2255; 31.4.2.2321; 31.4.2.2331; 31.4.2.2376; 31.4.2.2393; 31.4.2.2554ii; 31.4.2.2629; 31.4.2.2631i; 31.4.2.2632ii; 31.4.2.2638; 31.4.2.2661i; 31.4.2.2674; 31.4.2.2706a,b; 31.4.2.2734; 31.4.2.2739aop; 31.4.2.2793; 31.4.2.2797; 31.4.2.2823,2824; 31.4.2.2882; 31.4.2.2894; 31.4.2.2898; 31.4.2.2923; 31.4.2.2932; 31.4.2.2970; 31.4.2.3005; 31.4.2.3007; 31.4.2.3076; 31.4.2.3077aop; 31.4.2.3315op; 31.4.2.3382; 31.4.2.3413; 31.4.2.3414; 31.4.2.4256opiv; 31.4.2.4584aiii,biii; 31.4.2.4682ii; 31.4.2.4688; 31.4.2.4697ai,bi; 31.4.2.4700cii; 31.4.2.4703ii; 31.4.2.4718; 31.4.2.4762a,b; 31.4.2.4825ii; 31.4.2.4834ai,b; 31.4.2.4853ii; 31.4.2.4869a,bi; 31.4.2.4871; 31.4.2.4882aii,bii; 31.4.2.4883; 31.4.2.4885a,b; 31.4.2.4899; 31.4.2.4911; 31.4.2.4916ii; 31.4.2.4954; 31.4.2.4968; 31.4.2.4980bopii; $\quad 31.4 .2 .4994 \mathrm{ii}, 4985 \mathrm{op} ; \quad 31.4 .2 .5197 ; \quad 31.4 .2 .5219 \mathrm{ai}, \mathrm{bi} ; \quad 31.4 .2 .5243 ; \quad 31.4 .2 .5421 ; \quad 31.4 .2 .5466 \mathrm{aopviii}$; 31.4.2.5511aii,bii; 31.4.2.5523; 31.4.2.5527; 31.4.2.5613; 31.4.2.5767; 31.4.2.5785aviii,bvii; 31.4.2.5815aiii; 31.4.2.5815aopiii; 31.4.2.5840; 31.4.2.5898ii; 31.4.2.5915; 31.4.2.5936; 31.4.2.5937; 31.4.2.5947op; 31.4.2.5948opii; 31.4.2.5959; 31.4.2.5978aop; 31.4.2.5981opiii; 31.4.2.5998ii; 31.4.2.6125ii; 31.4.2.6171iii; 31.4.2.6191aiii; 31.4.2.6216aopii; 31.4.2.6274; 31.4.2.6305i; 31.4.2.6357opiv; 31.4.2.6364ii; 31.4.2.6441op; 31.4.2.6442; 31.4.2.6446; 31.4.2.6449a,b; 31.4.2.6457; 31.4.2.6478aiv; 31.4.2.6479opii; 31.4.2.6493aopii; 31.4.2.6512; 31.4.2.6520ii; 31.4.2.6521; 31.4.2.6586; 31.4.2.6707iii; 31.4.2.6721; 31.4.2.6833a,b; 31.4.2.6839; 31.4.2.6893; 31.4.2.6990; 31.4.2.7025; 31.4.2.8224opiii; 31.4.2.8224opiv; 31.4.2.8230op. 
Appendix 3. Growth form, ecological preferences, vegetation units sensu Denk (2016) and modern morphologically analoguous allies for the floristic elements described from Kassanoi, Pitsidia, Metochia and Kastellios Hill

\begin{tabular}{|c|c|c|c|c|}
\hline Taxon & $\begin{array}{l}\text { Growth } \\
\text { form }\end{array}$ & Ecology & $\begin{array}{c}\text { Vegetation units } \\
\text { (sensu Denk, 2016) }\end{array}$ & $\begin{array}{l}\text { Modern morphologically } \\
\text { analogue allies }\end{array}$ \\
\hline \multicolumn{5}{|c|}{ Pitsidia - Kassanoi - Metochia (macro) floristic elements } \\
\hline "Pteris" oeningensis & Fern & Indifferent & & Polypodiophyta \\
\hline $\begin{array}{l}\text { Tetraclinis } \mathrm{cf} . \\
\text { salicornioides }\end{array}$ & Shrub $_{\text {gym }}$ & $\begin{array}{l}\text { Well-drained lowland and upland } \\
\text { forests or scrubs }\end{array}$ & VU5, VU6 & Tetraclinis articulata \\
\hline Taxodium dubium & Tree $_{\text {gym }}$ & Swamp & VU3 & Taxodium spp. \\
\hline Pinus pitsidiensis & Tree $_{\text {gym }}$ & Indifferent & & $\begin{array}{l}\text { Pinus canariensis, } \\
P . \text { roxburghii, } P \text {. kesiya }\end{array}$ \\
\hline Pinus sp., 2-needled & Tree $_{\text {gym }}$ & Indifferent & & Pinus subgen. Pinus \\
\hline Pinus spp., 5-needled & Tree $_{\text {gym }}$ & Indifferent & & Pinus subgen. Strobus \\
\hline Daphnogene polymorpha & Tree ${ }_{\text {ang }}$ & Riparian, well-drained lowland forest & VU4, VU5 & Cinnamomum camphora \\
\hline ?Lindera ovata & Tree $_{\text {ang }}$ & $\begin{array}{l}\text { Well-drained lowland and upland } \\
\text { forests }\end{array}$ & VU5, VU6 & Lauraceae \\
\hline $\begin{array}{l}\text { ?Lauraceae, gen. et sp. } \\
\text { indet. }\end{array}$ & Tree $_{\text {ang }}$ & $\begin{array}{l}\text { Well-drained lowland and upland } \\
\text { forests }\end{array}$ & VU5, VU6 & Lauraceae \\
\hline Sabalites sp. & $\begin{array}{l}\text { Tree, } \\
\text { shrub }_{\text {ang }}\end{array}$ & Swamp, well-drained lowland forest & VU0, VU3, VU5 & Coryphoideae \\
\hline Monocotylophyllum spp. & Herb & Indifferent & & \\
\hline Liquidambar europaea & Tree $_{\text {ang }}$ & $\begin{array}{l}\text { Swamp, riparian, well-drained } \\
\text { lowland forest }\end{array}$ & VU3, VU4, VU5 & $\begin{array}{l}\text { Liquidambar styraciflua, } \\
\text { L. orientalis }\end{array}$ \\
\hline Leguminosites spp. & Tree ${ }_{\text {ang }}$ & Indifferent & & Fabaceae \\
\hline $\begin{array}{l}\text { Podocarpium } \\
\text { podocarpum }\end{array}$ & Tree ${ }_{\text {ang }}$ & $\begin{array}{l}\text { Well-drained lowland and upland } \\
\text { forests }\end{array}$ & VU5, VU6 & $\begin{array}{l}\text { Detarieae-Ampherstieae } \\
\text { complex of Caesalpinioideae }\end{array}$ \\
\hline Mimosites sp. & $\begin{array}{l}\text { Tree, } \\
\text { shrub }_{\text {ang }}\end{array}$ & Step-like midowes & VU0 & Mimosoideae \\
\hline $\begin{array}{l}\text { Rosaceae, gen. et sp. } \\
\text { indet. }\end{array}$ & $\begin{array}{l}\text { Tree, } \\
\text { shrub }_{\text {ang }}\end{array}$ & $\begin{array}{l}\text { well-drained lowland and upland } \\
\text { forests }\end{array}$ & VU5, VU6 & Rosaceae \\
\hline Berchemia multinervis & $\begin{array}{l}\text { Climbing, } \\
\text { shrub }_{\text {ang }}\end{array}$ & Well-drained lowland forest & VU5 & $\begin{array}{l}\text { Berhemia scandens, B. lineata, } \\
\text { B. pauciflora, B. racemosa }\end{array}$ \\
\hline Ziziphus paradisiaca & $\begin{array}{l}\text { Tree, } \\
\text { shrub }_{\text {ang }}\end{array}$ & $\begin{array}{l}\text { Well-drained lowland and upland } \\
\text { forests or scrubs }\end{array}$ & VU5, VU6 & Rhamnaceae \\
\hline Ulmus cf. plurinervia & Tree ${ }_{\text {ang }}$ & well-drained lowland forest & VU5 & Ulmus spp. \\
\hline Ulmus sp. & Tree ${ }_{\text {ang }}$ & Riparian, well-drained lowland forest & VU4, VU5 & Ulmus spp. \\
\hline ?Zelkova zelkovifolia & $\begin{array}{l}\text { Tree, } \\
\text { shrub }_{\text {ang }}\end{array}$ & well-drained lowland forest & VU0, VU5 & Zelkova spp. \\
\hline Quercus pseudocastanea & Tree $_{\text {ang }}$ & Well-drained lowland forest & VU5 & $\begin{array}{l}\text { Quercus section Quercus } \\
\text { group petraea }\end{array}$ \\
\hline Quercus kubinyii & Tree $_{\text {ang }}$ & Well-drained lowland forest & VU5 & Quercus section Cerris \\
\hline Quercus mediterranea & Tree $_{\text {ang }}$ & $\begin{array}{l}\text { Well-drained lowland and upland } \\
\text { forests }\end{array}$ & VU5, VU6 & $\begin{array}{l}\text { Quercus section Cerris group } \\
\text { Ilex }\end{array}$ \\
\hline Quercus sp. & Tree $_{\text {ang }}$ & Indifferent & & Quercus spp. \\
\hline Fagus gussonii & Tree $_{\text {ang }}$ & $\begin{array}{l}\text { Well-drained lowland and upland } \\
\text { forests }\end{array}$ & VU 5, VU6 & Fagus sylvatica \\
\hline Myrica lignitum & Shrub ${ }_{\text {ang }}$ & Swamp, riparian & VU3, VU4 & $\begin{array}{l}\text { M. cerifera, } M . \text { pensylvanica, } \\
\text { M. heterophylla }\end{array}$ \\
\hline Carya sp. & Tree $_{\text {ang }}$ & Riparian, well-drained lowland forest & VU4, VU5 & Carya spp. \\
\hline Pterocarya sp. & Tree $_{\text {ang }}$ & Well-drained lowland forest & VU5 & Pterocarya spp. \\
\hline $\begin{array}{l}\text { Engelhardia } \\
\text { orsbergensis }\end{array}$ & Tree $_{\text {ang }}$ & Well-drained lowland forest & VU5 & $\begin{array}{l}\text { Engelhardia roxburghiana, } \\
\text { Oreomunnea mexicana }\end{array}$ \\
\hline $\begin{array}{l}\text { Juglandaceae, gen. et } \\
\text { sp. indet. }\end{array}$ & Tree $_{\text {ang }}$ & Indifferent & & Juglandaceae \\
\hline cf. Ostrya sp. & Tree $_{\text {ang }}$ & Well-drained lowland forest & VU0, VU5 & Ostrya \\
\hline Salix angusta & $\begin{array}{l}\text { Tree, } \\
\text { shrub }_{\text {ang }}\end{array}$ & Riparian, well-drained lowland forest & VU4, VU5 & Salix viminalis $\mathrm{L}$. \\
\hline Salix spp. & $\begin{array}{l}\text { Tree, } \\
\text { shrub }_{\text {ang }}\end{array}$ & Riparian, well-drained lowland forest & VU4, VU5 & Salix spp. \\
\hline Populus latior & Tree ${ }_{\text {ang }}$ & Riparian, well-drained lowland forest & VU4, VU5 & Populus alba \\
\hline Populus sp. & Tree ${ }_{\text {ang }}$ & $\begin{array}{l}\text { Riparian, } \\
\text { well-drained lowland forest }\end{array}$ & VU4, VU5 & Populus spp. \\
\hline Decodon gibbosus & Shrub ang & Aquatic, swamp & VU1, VU3 & Decodon verticillatus \\
\hline Acer tricuspidatum & Tree $_{\text {ang }}$ & $\begin{array}{l}\text { Swamp, well-drained lowland and } \\
\text { upland forests }\end{array}$ & VU3, VU5, VU6 & Acer section Rubra \\
\hline
\end{tabular}


Appendix 3. Continued

\begin{tabular}{|c|c|c|c|c|}
\hline Taxon & $\begin{array}{l}\text { Growth } \\
\text { form }\end{array}$ & Ecology & $\begin{array}{c}\text { Vegetation units } \\
\text { (sensu Denk, 2016) }\end{array}$ & $\begin{array}{l}\text { Modern morphologically } \\
\text { analogue allies }\end{array}$ \\
\hline Acer integrilobum & Tree $_{\text {ang }}$ & $\begin{array}{l}\text { Well-drained lowland and upland } \\
\text { forests }\end{array}$ & VU5, VU6 & Acer section Palmata \\
\hline ?Acer aegopodifolium & Tree ${ }_{\text {ang }}$ & $\begin{array}{l}\text { Well-drained lowland and upland } \\
\text { forests }\end{array}$ & VU5, VU6 & Acer section Trifolia \\
\hline Fraxinus sp. & Tree $_{\text {ang }}$ & Riparian, well-drained lowland forest & VU4, VU5 & Fraxinus spp. \\
\hline \multicolumn{5}{|c|}{ Kastellios Hill (diaspores) floristic elements } \\
\hline Cedrus & Tree $_{\text {gym }}$ & $\begin{array}{l}\text { Well-drained lowland and upland } \\
\text { forests }\end{array}$ & VU7 & \\
\hline Pinus Haploxylon type & Tree $_{\text {gym }}$ & Indifferent & & \\
\hline Pinus Diploxylon type & Tree $_{\text {gym }}$ & Indifferent & & \\
\hline Tsuga & Tree $_{\text {gym }}$ & $\begin{array}{l}\text { Well-drained lowland and upland } \\
\text { forests }\end{array}$ & VU7 & \\
\hline Picea & Tree $_{\text {gym }}$ & $\begin{array}{l}\text { Well-drained lowland and upland } \\
\text { forests }\end{array}$ & VU7 & \\
\hline Abies & Tree $_{\text {gym }}$ & $\begin{array}{l}\text { Well-drained lowland and upland } \\
\text { forests }\end{array}$ & VU7 & \\
\hline $\begin{array}{l}\text { Pinaceae gen. at sp. } \\
\text { indet. }\end{array}$ & Tree $_{\text {gym }}$ & Indifferent & & \\
\hline Sciadopytis & Tree $_{\text {gym }}$ & $\begin{array}{l}\text { Well-drained lowland and upland } \\
\text { forests }\end{array}$ & VU7 & \\
\hline Taxodiaceae & Tree $_{\text {gym }}$ & Swamp & VU3 & \\
\hline Cupressaceae & $\begin{array}{l}\text { Tree } \\
\text { shrub }_{\text {gym }}\end{array}$ & $\begin{array}{l}\text { Well-drained lowland and upland } \\
\text { forests }\end{array}$ & VU5, VU6 & \\
\hline Symplocos & Shrub & $\begin{array}{l}\text { Swamp, riparian, well-drained low- } \\
\text { land and upland forests }\end{array}$ & VU3-VU6 & \\
\hline Nyssa & Tree $_{\text {ang }}$ & Swamp, well-drained lowland forest & VU3, VU5 & \\
\hline Palmae & $\begin{array}{l}\text { Tree } \\
\text { shrub } \\
\text { shrg }_{\text {ang }}\end{array}$ & Swamp, well-drained lowland forest & VU0, VU3, VU5 & \\
\hline Engelhardia & Tree ${ }_{\text {ang }}$ & Well-drained lowland forest & VU5 & \\
\hline Carya & Tree $_{\text {ang }}$ & Riparian, well-drained lowland forest & U4, VU5 & \\
\hline Juglans & Tree $_{\text {ang }}$ & Well-drained lowland forest & VU5 & \\
\hline Myricaceae & $\begin{array}{l}\text { Tree }_{\text {ang }} \\
\text { shrub }_{\text {ang }}\end{array}$ & $\begin{array}{l}\text { Swamp, riparian, well-drained low- } \\
\text { land forest }\end{array}$ & VU3, VU4, VU5 & \\
\hline Ilex & $\begin{array}{l}\text { Tree } \\
\text { shrob } \\
\text { shrub }_{\text {ang }}\end{array}$ & $\begin{array}{l}\text { Well-drained lowland and upland } \\
\text { forests }\end{array}$ & VU5, VU6 & \\
\hline Castanea type & Tree ${ }_{\text {ang }}$ & Well-drained lowland forest & VU5 & \\
\hline cf. Quercus & Tree $_{\text {ang }}$ & Indifferent & & \\
\hline Ulmus/Zelkova & Tree $_{\text {ang }}$ & $\begin{array}{l}\text { Swamp, riparian, well-drained low- } \\
\text { land forest }\end{array}$ & $\begin{array}{l}\text { VU0, VU3, VU4, } \\
\text { VU5 }\end{array}$ & \\
\hline Quercus & Tree ${ }_{\text {ang }}$ & Indifferent & & \\
\hline Tilia & Tree $_{\text {ang }}$ & Well-drained lowland forest & VU5 & \\
\hline Ostrya & Tree $_{\text {ang }}$ & Well-drained lowland forest & VU0, VU5 & \\
\hline Carpinus & Tree $_{\text {ang }}$ & well-drained lowland forest & VU5 & \\
\hline Corylus & $\begin{array}{l}\text { Tree } \\
\text { shrg } \\
\text { shrub }_{\text {ang }}\end{array}$ & $\begin{array}{l}\text { Well-drained lowland and upland } \\
\text { forests }\end{array}$ & VU5, VU6 & \\
\hline Acer & Tree $_{\text {ang }}$ & Indifferent & & \\
\hline Salix & $\begin{array}{l}\text { Tree }_{\text {ang }} \\
\text { shrub } \\
\text { ang }\end{array}$ & Riparian, well-drained lowland forest & U4, VU5 & \\
\hline Alnus & $\begin{array}{l}\text { Tree } \\
\text { shrg } \\
\text { shrub } \\
\text { ang }\end{array}$ & Swamp, riparian & VU3, VU4 & \\
\hline Betula & Tree $_{\text {ang }}$ & $\begin{array}{l}\text { Well-drained lowland and upland } \\
\text { forests }\end{array}$ & VU5, VU6 & \\
\hline Ephedra & shrub $_{\text {ang }}$ & Open, light forest & VU0 & \\
\hline Artemisia & Herb dry & Open, dry meadows & VU0 & \\
\hline Asteraceae & Herb & Wet and dry meadows & VU0, VU2 & \\
\hline $\begin{array}{l}\text { Amaranthaceae/ } \\
\text { Chenopodiaceae }\end{array}$ & Herb dry & Open, dry meadows, salty soils & VU0 & \\
\hline Poaceae & Herb & Indifferent & & \\
\hline $\begin{array}{l}\text { Caryophyllaceae/ } \\
\text { Apiaceae }\end{array}$ & Herb & Indifferent & & \\
\hline Cyperaceae & Herb wet & Bogs, wet meadows & VU2 & \\
\hline Nymphaceae & $\begin{array}{l}\text { Aquatic } \\
\text { herb }\end{array}$ & Aquatic & VU1 & \\
\hline Typhaceae & Herb wet & Bogs, wet meadows & VU2 & \\
\hline Ericaceae & $\begin{array}{l}\text { Herb, } \\
\text { shrub }\end{array}$ & Indifferent & & \\
\hline
\end{tabular}


Appendix 4. Pollen diagram from Kastellios Hill in Messara Basin, Crete; sediment layers: K2, upper lignitic clay and lower lignite clay (modified from Sen et al., 1986).

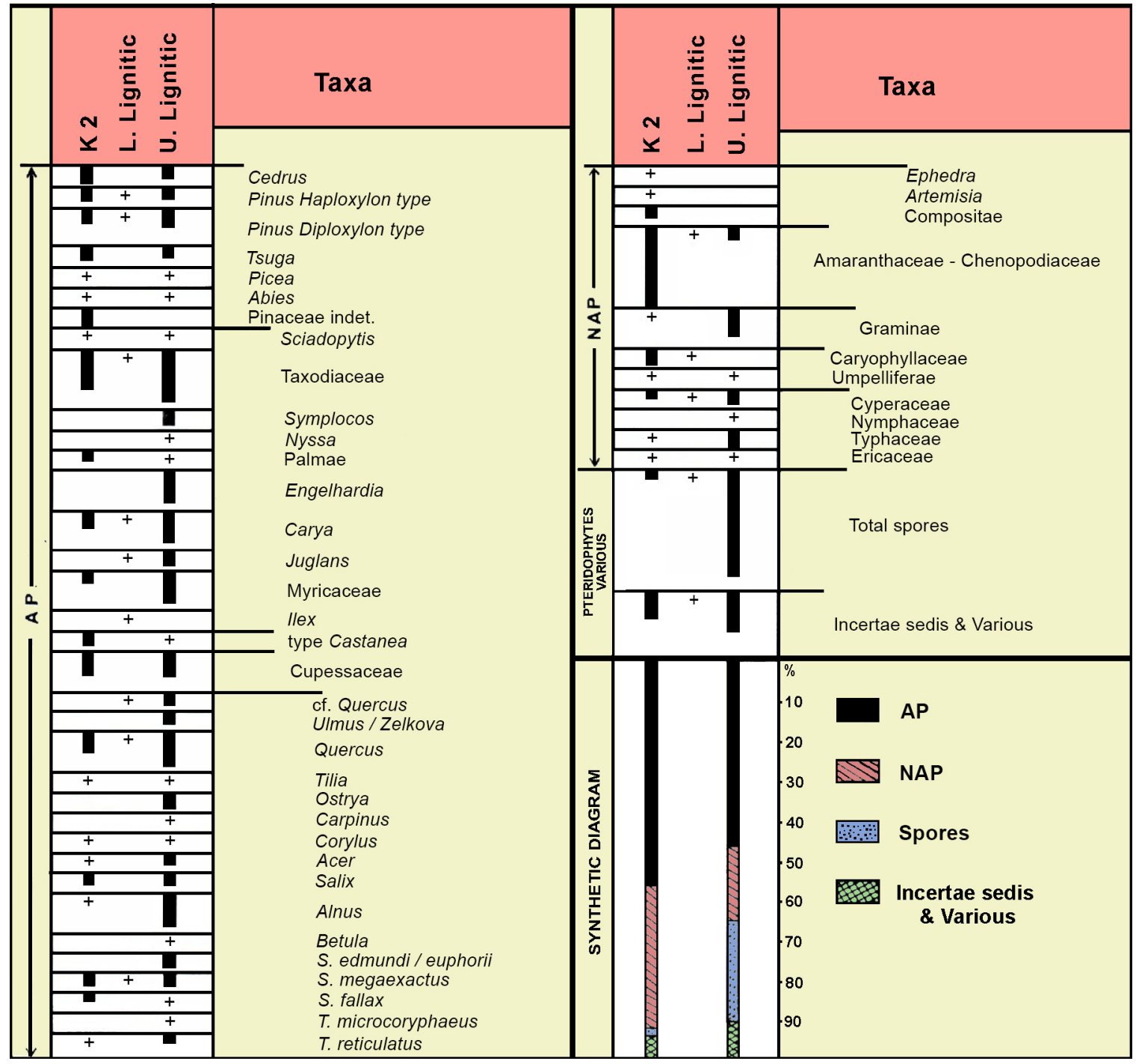


Appendix 5. IPR Vegetation Analysis, scoring sheets for a. Pitisidia, b. Kassanoi and c. Metochia

\begin{tabular}{|c|c|c|c|c|c|c|c|c|c|c|c|c|c|}
\hline \multirow{2}{*}{$\begin{array}{l}\text { a. Pitsidia (Messara) } \\
\text { Taxa }\end{array}$} & \multicolumn{9}{|c|}{ ZONAL } & \multicolumn{3}{|c|}{ AZONAL } & \multirow{2}{*}{ 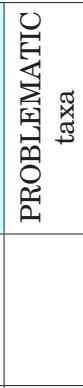 } \\
\hline & $\begin{array}{l}\text { 空 } \\
\text { 空 } \\
\text { 总 } \\
0 \\
0\end{array}$ & คำ & 舆 & છ & 㽦 & 兄突 & 鱼学 & 䆓公 & $\begin{array}{l}\text { 올 } \\
\text { 空 } \\
\text { 空 }\end{array}$ & 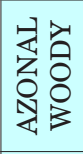 & 妾 & 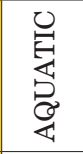 & \\
\hline Thallus & & & & & & & & & & & & 1.00 & \\
\hline "Pteris" oeningensis & & & & & & & & & 0.50 & & 0.50 & & \\
\hline Tetraclinis cf. salicornioides & 1.00 & & & & & & & & & & & & \\
\hline Taxodium dubium & & & & & & & & & & 1.00 & & & \\
\hline Pinus pitsidiensis & & & & & & & & & & 1.00 & & & \\
\hline Pinus sp. 1, subgen, Pinus, 2-needled & 1.00 & & & & & & & & & & & & \\
\hline $\begin{array}{l}\text { Pinus sp. 2. subgen. Strobus, } \\
\text { 5-needled }\end{array}$ & 1.00 & & & & & & & & & & & & \\
\hline \multicolumn{14}{|l|}{ Pinus sp. fascicle bracts } \\
\hline \multicolumn{14}{|l|}{ ovulate cone scales subgen. Pinus } \\
\hline \multicolumn{14}{|l|}{ ovulate cone scales subgen. Strobus } \\
\hline \multicolumn{14}{|l|}{ Pinus seeds 2 types } \\
\hline \multicolumn{14}{|l|}{ Pinus pollen cones 2 types } \\
\hline \multicolumn{14}{|l|}{ Pinus bud scales } \\
\hline Daphnogene polymorpha & & & 0.50 & & & & & & & 0.50 & & & \\
\hline ?Lindera ovata & & 1.00 & & & & & & & & & & & \\
\hline ?Lauraceae & & & 1.00 & & & & & & & & & & \\
\hline Liqudambar europaea & & 0.50 & & & & & & & & 0.50 & & & \\
\hline Leguminosites sp. 1 & & & & & 1.00 & & & & & & & & \\
\hline Leguminosites sp. 2 & & & & & 1.00 & & & & & & & & \\
\hline Podocarpium podocarpum & & & & & 1.00 & & & & & & & & \\
\hline Mimosites sp. & & & & & 1.00 & & & & & & & & \\
\hline Rosaceae type 1 & & 1.00 & & & & & & & & & & & \\
\hline Ulmus cf. plurinervia & & 0.75 & & 0.25 & & & & & & & & & \\
\hline Ulmus sp. & & 0.50 & & 0.25 & & & & & & 0.25 & & & \\
\hline ?Zelkova zelkovifolia & & 0.50 & & 0.50 & & & & & & & & & \\
\hline Quercus pseudocastanea & & 1.00 & & & & & & & & & & & \\
\hline Quercus kubinyii & & 0.50 & & 0.50 & & & & & & & & & \\
\hline Quercus mediterranea & & & 0.50 & 0.50 & & & & & & & & & \\
\hline Fagus gussonii & & 1.00 & & & & & & & & & & & \\
\hline Myrica lignitum & & & & & & & & & & 1.00 & & & \\
\hline \multicolumn{14}{|l|}{ Myrica ceriferiformis } \\
\hline \multicolumn{14}{|l|}{ Myrica cf. goeppertii } \\
\hline Carya sp. & & 0.50 & & & & & & & & 0.50 & & & \\
\hline Pterocarya sp. & & 1.00 & & & & & & & & & & & \\
\hline Juglandaceae & & 1.00 & & & & & & & & & & & \\
\hline cf. Ostrya sp. & & 1.00 & & & & & & & & & & & \\
\hline Salix sp. & & 0.50 & & & & & & & & 0.50 & & & \\
\hline Populus latior & & 0.50 & & & & & & & & 0.50 & & & \\
\hline Populus sp & & 0.50 & & & & & & & & 0.50 & & & \\
\hline Acer tricuspidatum & & 0.50 & & & & & & & & 0.50 & & & \\
\hline Acer integrilobum & & 1.00 & & & & & & & & & & & \\
\hline ?Acer aegopodifolium & & 1.00 & & & & & & & & & & & \\
\hline Monocotylophyllum sp. 1-5 & & & & & & & & & & & 5.00 & & \\
\hline Dicotylophyllum sp. 1 & & 0.33 & 0.33 & 0.33 & & & & & & & & & \\
\hline Dicotylophyllum sp. 2 & & & & 1.00 & & & & & & & & & \\
\hline Dicotylophyllum sp. 3 & & 1.00 & & & & & & & & & & & \\
\hline Dicotylophyllum sp. 4 & & 1.00 & & & & & & & & & & & \\
\hline Dicotylophyllum sp. 5 & & 0.33 & 0.33 & 0.33 & & & & & & & & & \\
\hline Dicotylophyllum sp. 6 & & & 1.00 & & & & & & & & & & \\
\hline Dicotylophyllum sp. 7 & & & 0.50 & 0.50 & & & & & & & & & \\
\hline Dicotylophyllum sp. 8 & & 0.50 & & 0.50 & & & & & & & & & \\
\hline Dicotylophyllum sp. 9 & & 1.00 & & & & & & & & & & & \\
\hline Dicotylophyllum sp. 10 & & 0.50 & & 0.50 & & & & & & & & & \\
\hline
\end{tabular}


Appendix 5. Continued

\begin{tabular}{|c|c|c|c|c|c|c|c|c|c|c|c|c|c|}
\hline \multirow{2}{*}{$\begin{array}{l}\text { a. Pitsidia (Messara) } \\
\text { Taxa }\end{array}$} & \multicolumn{9}{|c|}{ ZONAL } & \multicolumn{3}{|c|}{ AZONAL } & \multirow{2}{*}{ 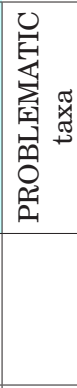 } \\
\hline & $\begin{array}{l}\text { Tr } \\
\text { 空 } \\
\text { O } \\
\text { O }\end{array}$ & 穴 & 兵 & 它 & 岂 & 员突 & 穵学 & 窝愛 & 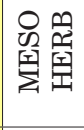 & 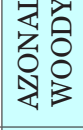 & 学 & 焉 & \\
\hline Dicotylophyllum sp. 11 & & 0.33 & 0.33 & 0.33 & & & & & & & & & \\
\hline Dicotylophyllum sp. 12 & & 1.00 & & & & & & & & & & & \\
\hline Dicotylophyllum sp. 13 & & 1.00 & & & & & & & & & & & \\
\hline Sum of taxa (51) & 3.00 & 22.24 & 4.49 & 5.49 & 4.00 & 0.00 & 0.00 & 0.00 & 0.50 & 6.75 & 5.50 & 1.00 & 0.00 \\
\hline Percentage of zonal taxa & 7.55 & 55.99 & 11.30 & 13.82 & 10.07 & 0.00 & 0.00 & 0.00 & 1.26 & & & & \\
\hline percentage of zonal woody angiosperms & & 61.40 & 12.40 & 15.16 & 11.04 & 0.00 & & & & & & & \\
\hline Sum of \% SCL+ LEG & 26.20 & & & & & & & & & & & & \\
\hline $\begin{array}{l}\text { Sum of \% DRY HERB + MESO HERB } \\
\text { (ZONAL HERB) }\end{array}$ & 1.26 & & & & & & & & & & & & \\
\hline
\end{tabular}

\begin{tabular}{|c|c|c|c|c|c|c|c|c|c|c|c|c|c|}
\hline \multirow{2}{*}{$\begin{array}{l}\text { b. Kassanoi (Messara) } \\
\text { Taxa }\end{array}$} & \multicolumn{9}{|c|}{ ZONAL } & \multicolumn{3}{|c|}{ AZONAL } & \multirow{2}{*}{ 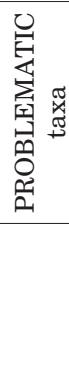 } \\
\hline & $\begin{array}{l}\text { 空 } \\
\text { 突 } \\
\text { O }\end{array}$ & Яิબ & 兵 & છ & 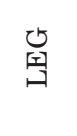 & 兄突 & 爱学 & 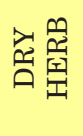 & $\begin{array}{l}\text { 요 } \\
\text { 望 } \\
\text { 空䍃 }\end{array}$ & 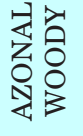 & 蛋 & 岕 & \\
\hline Polypodiophyta & & & & & & & & & 0,50 & & 0.50 & & \\
\hline Tetraclinis cf. salicornioides & 1.00 & & & & & & & & & & & & \\
\hline Daphnogene polymorpha & & & 0.50 & & & & & & & 0.50 & & & \\
\hline Podocarpium podocarpum & & & & & 1.00 & & & & & & & & \\
\hline Rosaceae type 2 & & 1.00 & & & & & & & & & & & \\
\hline Berchemia multnervis & & 0.50 & & 0.50 & & & & & & & & & \\
\hline Ulmus cf. plurinervia & & 0.75 & & 0.25 & & & & & & & & & \\
\hline Quercus sp. & & 1.00 & & & & & & & & & & & \\
\hline Myrica lignitum & & & & & & & & & & 1.00 & & & \\
\hline Salix angusta & & 0.50 & & & & & & & & 0.50 & & & \\
\hline ?Salix sp. & & 0.50 & & & & & & & & 0.50 & & & \\
\hline Populus latior & & 0.50 & & & & & & & & 0.50 & & & \\
\hline Decodon gibbosus & & & & & & & & & & 0.50 & & 0.50 & \\
\hline Fraxinus sp. & & 0.50 & & & & & & & & 0.50 & & & \\
\hline Monocotylophyllum sp. 6-8 & & & & & & & & & & & 3.00 & & \\
\hline Dicotylophyllum sp. 14 & & & 1.00 & & & & & & & & & & \\
\hline Dicotylophyllum sp. 15 & & & 1.00 & & & & & & & & & & \\
\hline Dicotylophyllum sp. 16 & & 0.50 & 0.50 & & & & & & & & & & \\
\hline Dicotylophyllum sp. 17 & & 0.50 & 0.50 & & & & & & & & & & \\
\hline Dicotylophyllum sp. 18 & & 0.50 & 0.50 & & & & & & & & & & \\
\hline Dicotylophyllum sp. 19 & & & & 1.00 & & & & & & & & & \\
\hline Sum of taxa (23) & 1.00 & 6.75 & 4.00 & 1.75 & 1.00 & 0.00 & 0.00 & 0.00 & 0.50 & 4.00 & 3.50 & 0.50 & 0.00 \\
\hline Percentage of zonal taxa & 6.67 & 45.00 & 26.67 & 11.67 & 6.67 & 0.00 & 0.00 & 0.00 & 3.33 & & & & \\
\hline $\begin{array}{l}\text { percentage of zonal woody } \\
\text { angiosperms }\end{array}$ & & 50.00 & 29.63 & 12.96 & 7.41 & 0.00 & & & & & & & \\
\hline
\end{tabular}


Appendix 5. Continued

\begin{tabular}{|c|c|c|c|c|c|c|c|c|c|c|c|c|c|}
\hline \multirow{2}{*}{$\begin{array}{l}\text { c. Metochia (Gavdos) } \\
\text { Taxa }\end{array}$} & \multicolumn{9}{|c|}{ ZONAL } & \multicolumn{3}{|c|}{ AZONAL } & \multirow{2}{*}{ 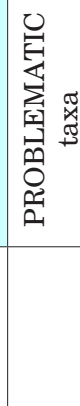 } \\
\hline & 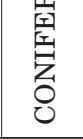 & คำ & 됩 & $\ddot{\mho}$ & 祍 & 乬悬 & 学学 & 䆓贫 & 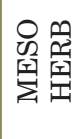 & 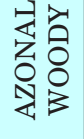 & 茎 & 宽 & \\
\hline Tetraclinis salicornioides & 1.00 & & & & & & & & & & & & \\
\hline Taxodium dubium & & & & & & & & & & 1.00 & & & \\
\hline Pinus sp. 1, subgen, Pinus, 2-needled & 1.00 & & & & & & & & & & & & \\
\hline $\begin{array}{l}\text { Pinus sp. 2. subgen. Strobus, } \\
\text { 5-needled (in this study) }\end{array}$ & 1.00 & & & & & & & & & & & & \\
\hline Daphnogene sp. & & & 0.50 & & & & & & & 0.50 & & & \\
\hline Laurophyllum sp. & & & 1.00 & & & & & & & & & & \\
\hline ?Lindera ovata & & 1.00 & & & & & & & & & & & \\
\hline ?Sassafras sp. & & 1.00 & & & & & & & & & & & \\
\hline Sabalites sp (in this study) & & & & & & 0.50 & & & & 0.50 & & & \\
\hline $\begin{array}{l}\text { Leguminosites } \mathrm{sp.} 1 / \\
\text { Leguminocarpon } \mathrm{sp} .\end{array}$ & & & & & 1.00 & & & & & & & & \\
\hline Leguminosites sp. 2 & & 0.50 & & & 0.50 & & & & & & & & \\
\hline Leguminosites sp. 3 & & 0.50 & & & 0.50 & & & & & & & & \\
\hline Leguminosites sp. 4 & & 0.50 & & & 0.50 & & & & & & & & \\
\hline ?Leguminosites sp. 3 (in this study) & & & & & 1.00 & & & & & & & & \\
\hline Paliurus tiliifolius & & 0.50 & & 0.50 & & & & & & & & & \\
\hline Ziziphus paradisiaca (in this study) & & 0.50 & & 0.50 & & & & & & & & & \\
\hline Ulmus ?plurinervia & & 0.75 & & 0.25 & & & & & & & & & \\
\hline Quercus mediterranea (in this study) & & & 0.50 & 0.50 & & & & & & & & & \\
\hline Fagus gussonii & & 1.00 & & & & & & & & & & & \\
\hline Myrica lignitum & & & & & & & & & & 1.00 & & & \\
\hline Engelhardia orsbergensis & & 0.50 & 0.50 & & & & & & & & & & \\
\hline Betula sp. & & 1.00 & & & & & & & & & & & \\
\hline ?Carpinus & & 1.00 & & & & & & & & & & & \\
\hline Salix cf. angusta & & 0.50 & & & & & & & & 0.50 & & & \\
\hline Populus latior & & 0.50 & & & & & & & & 0.50 & & & \\
\hline Sapindus graecus & & 1.00 & & & & & & & & & & & \\
\hline Acer angustilobum & & 1.00 & & & & & & & & & & & \\
\hline Ailanthus pythii & & 1.00 & & & & & & & & & & & \\
\hline Monocotyledonae indet. & & & & & & & & & & & 1.00 & & \\
\hline $\begin{array}{l}\text { Monocotylophyllum sp. } 10 \\
\text { (in this study) }\end{array}$ & & & & & & & & & & & 1.00 & & \\
\hline Dicotylophyllum sp. 1 & & 1.00 & & & & & & & & & & & \\
\hline Dicotylophyllum sp. 2 & & 1.00 & & & & & & & & & & & \\
\hline Dicotylophyllum sp. 3 & & 0.50 & 0.50 & & & & & & & & & & \\
\hline Dicotylophyllum sp. 4 & & 0.50 & 0.50 & & & & & & & & & & \\
\hline Dicotylophyllum sp. 5 & & 1.00 & & & & & & & & & & & \\
\hline Dicotylophyllum sp. 6 & & & 1.00 & & & & & & & & & & \\
\hline Dicotylophyllum sp. 20 (in this study) & & & 1.00 & & & & & & & & & & \\
\hline Dicotylophyllum sp. 21 (in this study) & & 0.50 & & 0.50 & & & & & & & & & \\
\hline Sum of taxa (38) & 3.00 & 17.00 & 5.50 & 2.50 & 3.50 & 0.50 & 0.00 & 0.00 & 0.00 & 4.00 & 2.00 & 0.00 & 0.00 \\
\hline Percentage of zonal taxa & 9.38 & 53.13 & 17.19 & 7.81 & 10.94 & 1.56 & 0.00 & 0.00 & 0.00 & & & & \\
\hline $\begin{array}{l}\text { percentage of zonal woody } \\
\text { angiosperms }\end{array}$ & & 58.62 & 18.97 & 8.62 & 12.07 & 1.72 & & & & & & & \\
\hline Sum of $\%$ SCL+ LEG & 20.69 & & & & & & & & & & & & \\
\hline $\begin{array}{l}\text { Sum of \% DRY HERB + MESO } \\
\text { HERB (ZONAL HERB) }\end{array}$ & 0.00 & & & & & & & & & & & & \\
\hline
\end{tabular}


Appendix 6. Metochia palaeoflora (Mantzouka et al., 2015), amended floristic list including the herein-described findings

\begin{tabular}{|c|c|c|c|c|c|}
\hline $\mathrm{Nr}$ & Family & Taxon & Remarks & Plant part/organ & Samples \\
\hline \multicolumn{6}{|c|}{ Gymnospermae } \\
\hline 1 & \multirow[t]{2}{*}{ Cupressaceae } & Tetraclinis salicornioides & & leafy twig/ segments & $\begin{array}{l}1 / 2 \\
+1 \text { in this study }\end{array}$ \\
\hline 2 & & Taxodium dubium & & foliage shoots & 2 \\
\hline 3 & \multirow{2}{*}{ Pinaceae } & Pinus sp., 2-needled & & needle fragments & 4 \\
\hline 4 & & Pinus sp., 5-needled & in this study & needle fragment & 1 \\
\hline
\end{tabular}

\section{Angiospermae}

\begin{tabular}{|c|c|c|c|c|c|}
\hline 5 & \multirow{4}{*}{ Lauraceae } & Daphnogene polymorpha & & leaves & $\begin{array}{l}7 \\
+1 \text { in this study }\end{array}$ \\
\hline 6 & & Laurophyllum sp. & & leaves & 11 \\
\hline 7 & & ?Lindera ovata & & leaves & $\begin{array}{l}6 \\
+2 \text { in this study }\end{array}$ \\
\hline 8 & & ?Sassafras sp. & & leaves & 2 \\
\hline 9 & Arecaceae & Sabalites sp. & in this study & leaf & 1 \\
\hline 10 & \multirow[t]{2}{*}{ Fabaceae } & $\begin{array}{l}\text { Leguminosites spp. } \\
\text { (5 different types) }\end{array}$ & $\begin{array}{l}\text { (one newly reported } \\
\text { taxon) in this study }\end{array}$ & leaflets & $\begin{array}{l}9 \\
+2 \text { in this study }\end{array}$ \\
\hline 11 & & Leguminocarpon sp. & & pod & 1 \\
\hline 12 & \multirow[t]{2}{*}{ Rhamnaceae } & $\begin{array}{l}\text { Paliurus tiliifolius } \\
\text { (Unger) Bůžek }\end{array}$ & & leaf & 1 \\
\hline 13 & & Ziziphus paradisiaca & in this study & leaves & 3 \\
\hline 14 & Ulmaceae & Ulmus ?plurinervia & & leaf & 1 \\
\hline 15 & \multirow[b]{2}{*}{ Fagaceae } & Quercus mediterranea & in this study & leaves & 2 \\
\hline 16 & & Fagus gussonii & & leaves & $\begin{array}{l}7 \\
+14 \text { in this } \\
\text { study }\end{array}$ \\
\hline 17 & Myricaceae & Myrica lignitum & & leaves & $\begin{array}{l}8 \\
+2 \text { in this study }\end{array}$ \\
\hline 18 & Juglandaceae & Engelhardia orsbergensis & & leaflets & $\begin{array}{l}4 \\
+2 \text { in this study }\end{array}$ \\
\hline 19 & \multirow{2}{*}{ Betulaceae } & Betula sp. & & leaves & 2 \\
\hline 20 & & ?Carpinus sp. & & leaf & 1 \\
\hline 21 & \multirow[b]{2}{*}{ Salicaceae } & Salix cf. angusta & & leaves & 9 \\
\hline 22 & & Populus latior & & leaf & $\begin{array}{l}1 \\
+1 \text { in this study }\end{array}$ \\
\hline 23 & \multirow{2}{*}{ Sapindaceae } & Sapindus graecus Unger & & leaflets & 3 \\
\hline 24 & & Acer angustilobum Heer & & leaf & 1 \\
\hline 25 & Simaroubaceae & $\begin{array}{l}\text { Ailanthus pythii } \\
\text { (Unger) Kovar-Eder et Kvaček }\end{array}$ & & leaflet & 1 \\
\hline 26 & $\begin{array}{l}\text { fam. indet. } \\
\text { Monocotyledonae }\end{array}$ & gen. et sp. indet. & & leaves & 5 \\
\hline 27 & $\begin{array}{l}\text { fam. indet. } \\
\text { Monocotyledonae }\end{array}$ & $\begin{array}{l}\text { Monocotyllophyllum sp. } \\
\text { (2 different types) }\end{array}$ & in this study & leaves & 3 \\
\hline 28 & $\begin{array}{l}\text { fam. indet. } \\
\text { Dicotyledonae }\end{array}$ & $\begin{array}{l}\text { Dicotylophyllum spp. } \\
\text { (8 different types) }\end{array}$ & $\begin{array}{l}\text { (two newly reported taxa) } \\
\text { in this study }\end{array}$ & leaves/leaflets & $\begin{array}{l}9 \\
+4 \text { in this study }\end{array}$ \\
\hline
\end{tabular}


Appendix 7. Makrilia palaeoflora (Sachse, 2004), amended floristic list including the newly described findings in Velitzelos D. et al. (2014) and Zidianakis (2018). Velitzelos D. et al. (2014) reported frond fragments of Sabal sp. (Arecaceae) from the Makrilia area. The location of the outcrop and its stratigraphic position have not been published yet

\begin{tabular}{|c|c|c|c|c|c|c|}
\hline \multirow[b]{2}{*}{ Nr. } & \multirow[b]{2}{*}{ Family } & \multirow[b]{2}{*}{$\begin{array}{c}\text { Taxon } \\
\text { (Sachse, 2004) }\end{array}$} & \multicolumn{2}{|c|}{ Remarks for revised or further taxa } & \multirow[b]{2}{*}{ Plant part/organ } & \multirow[b]{2}{*}{ Samples } \\
\hline & & & $\begin{array}{c}\text { Original } \\
\text { identification } \\
\text { in Sachse (2004) }\end{array}$ & $\begin{array}{l}\text { Reference } \\
\text { for revision }\end{array}$ & & \\
\hline \multicolumn{7}{|c|}{ Polipodiophyta } \\
\hline 1 & Equisetaceae & Equisetum sp. & & & stem & 1 \\
\hline \multicolumn{7}{|c|}{ Gymnospermae } \\
\hline 2 & \multirow{3}{*}{ Cupressaceae } & Tetraclinis salicornioides & & & $\begin{array}{l}\text { leafy twigs, } \\
\text { segments, cone }\end{array}$ & $2 / 2 / 1$ \\
\hline 3 & & Taxodium dubium & & & leafy shoot & 1 \\
\hline 4 & & gen. et sp. indet. & Zidianakis, 2018 & & leafy shoot & 1 \\
\hline 5 & \multirow{6}{*}{ Pinaceae } & $\begin{array}{l}\text { cf. Cathaya vel Keleteria } \\
\text { vel Cedrus sp. }\end{array}$ & & & cone scale & 1 \\
\hline 6 & & $\begin{array}{l}\begin{array}{l}\text { gen. et sp. indet. } \\
\text { (not Pinus) }\end{array} \\
\end{array}$ & Zidianakis, 2018 & & winged seed & 1 \\
\hline 7 & & Pinus cf. hepios (Unger) Heer & & & 2-needled dwarf shoot & 1 \\
\hline 8 & & $\begin{array}{l}\text { Pinus cf. hampeana (Unger) } \\
\text { Heer }\end{array}$ & & & $\begin{array}{l}\text { 2-needled dwarf shoot } \\
\text { with short needles }\end{array}$ & 1 \\
\hline 9 & & Pinus sp. 5-needled & & & dwarf shoot & 1 \\
\hline 10 & & Pinus sp. & & & needle fragments & 5 \\
\hline \multicolumn{7}{|c|}{ Angiospermae } \\
\hline 11 & \multirow[b]{2}{*}{ Magnoliaceae } & ?Magnolia sp. & \multicolumn{2}{|l|}{ problematic record } & leaf & 1 \\
\hline 12 & & $\begin{array}{l}\text { ?Illicum rhenanum } \\
\text { Kräusel et Weyland }\end{array}$ & \multicolumn{2}{|l|}{ problematic record } & leaf & 1 \\
\hline 13 & \multirow{3}{*}{ Lauraceae } & Daphnogene polymorpha & $\begin{array}{l}\text { Cinnamomo- } \\
\text { phyllum sp. }\end{array}$ & $\begin{array}{l}\text { Velitzelos D. et al., } \\
\text { (2014) and in this } \\
\text { study }\end{array}$ & leaves & 2 \\
\hline 14 & & $\begin{array}{l}\text { Laurophyllum spp. } \\
\text { (4 different types) }\end{array}$ & & & leaves & 10 \\
\hline 15 & & $\begin{array}{l}\text { Cinnamomophyllum polymor- } \\
\text { phum (A. Braun) Heer }\end{array}$ & \multicolumn{2}{|l|}{ problematic record } & leaf & 1 \\
\hline 16 & $\begin{array}{l}\text { Potamogeton- } \\
\text { aceae s.l. }\end{array}$ & Cymodocea vel Posidonia sp. & & & $\begin{array}{l}\text { rhizomes, } \\
\text { eaves }\end{array}$ & 5 \\
\hline 17 & Ruppiaceae & cf. Ruppia sp. & & & seed & 1 \\
\hline 18 & Smilacaceae & $\begin{array}{l}\text { Smilax cf. petiolata } \\
\text { (Weber) Weyland }\end{array}$ & & & leaves & 2 \\
\hline 19 & Berberidaceae & cf. Berberis vel Mahonia & $\begin{array}{l}\text { Dicotylophyllum } \\
\text { type } 9\end{array}$ & $\begin{array}{l}\text { Velitzelos D. et al., } \\
\text { (2014) listed this } \\
\text { element as } \\
\text { cf. Berberis }\end{array}$ & leaflets & 2 \\
\hline 20 & & Mahonia sp. & \multicolumn{2}{|c|}{ Zidianakis, 2018} & leaflet & 1 \\
\hline 21 & \multirow{2}{*}{ Buxaceae } & $\begin{array}{l}\text { Buxus cf. egeriana } \\
\text { Kvaček, Bǔžek et Holý }\end{array}$ & & & leaves & 2 \\
\hline 22 & & $\begin{array}{l}\text { Buxus pliocenica } \\
\text { Saporta et Marion }\end{array}$ & & & leaves & 3 \\
\hline 23 & Altingiaceae & Liquidambar sp. & \multicolumn{2}{|l|}{ Zidianakis, 2018} & infructescence & 1 \\
\hline 24 & Vitaceae & cf. Ampelopsis vel Vitis sp. & & & seed & 1 \\
\hline 25 & \multirow{9}{*}{ Fabaceae } & $\begin{array}{l}\text { Leguminosites spp. } \\
\text { (7 different types) }\end{array}$ & & & leaflets/leaf & $14 / 1$ \\
\hline 26 & & Podocarpium podocarpum & & & leaflets & 4 \\
\hline 27 & & ?Mimosites $\mathrm{sp}$ & & & leaflet, leaf frag. & $1 / 1$ \\
\hline 28 & & $\begin{array}{l}\text { ?Leguminosae gen. et sp. } \\
\text { indet. (heterogenous leaflets) }\end{array}$ & & & leaflets & 10 \\
\hline 29 & & cf. Leguminosites $\mathrm{sp}$. & \multirow{2}{*}{\multicolumn{2}{|c|}{ Zidianakis, 2018}} & seed & 1 \\
\hline 30 & & Leguminocarpon sp. & & & fruit & 1 \\
\hline 31 & & ?Cladastris sp. & \multicolumn{2}{|l|}{ problematic record } & leaflet, leaf frag. & $1 / 1$ \\
\hline 32 & & $\begin{array}{l}\text { ?Machaerium spp. } \\
\text { (2 different types) }\end{array}$ & \multicolumn{2}{|l|}{ problematic record } & leaflets & 2 \\
\hline 33 & & ?Swartzia sp. & \multicolumn{2}{|l|}{ problematic record } & leaflet & 1 \\
\hline 34 & Rhamnaceae & Ziziphus paradisiaca & $\begin{array}{l}\text { Dicotylophyllum } \\
\text { type. } 3\end{array}$ & Zidianakis, 2018 & leaves & 3 \\
\hline 35 & \multirow{3}{*}{ Ulmaceae } & cf. Ulmus plurinervia & & & leaf & 3 \\
\hline 36 & & Ulmus sp. & & & fruit & 1 \\
\hline 37 & & Zelkova zelkovifolia & & & leaf, twig with 3 leaves & $1 / 1$ \\
\hline
\end{tabular}


Appendix 7. Continued

\begin{tabular}{|c|c|c|c|c|c|c|}
\hline \multirow[b]{2}{*}{$\mathrm{Nr}$. } & \multirow[b]{2}{*}{ Family } & \multirow[b]{2}{*}{$\begin{array}{c}\text { Taxon } \\
\text { (Sachse, 2004) }\end{array}$} & \multicolumn{2}{|c|}{ Remarks for revised or further taxa } & \multirow[b]{2}{*}{ Plant part/organ } & \multirow[b]{2}{*}{ Samples } \\
\hline & & & $\begin{array}{c}\text { Original } \\
\text { identification } \\
\text { in Sachse (2004) }\end{array}$ & $\begin{array}{l}\text { Reference } \\
\text { for revision }\end{array}$ & & \\
\hline 38 & \multirow[t]{4}{*}{ Fagaceae } & Fagus gussonii & $\begin{array}{l}\text { Fagus type gus- } \\
\text { sonii and Fagus } \\
\text { type attenuata }\end{array}$ & $\begin{array}{l}\text { Denk et al., 2004; } \\
\text { Velitzelos et al., } \\
2014 ; \\
\text { Mantzouka et al., } \\
2015 \text { and in this } \\
\text { study }\end{array}$ & leaves & 13 \\
\hline 39 & & ?Quercus kubinyii & & & leaf & 1 \\
\hline 40 & & Quercus mediterranea & & & leaves & 4 \\
\hline 41 & & Quercus sp. & & & acorn & 1 \\
\hline 42 & & $\begin{array}{l}\text { cf. Quercus rhenana (Kräu- } \\
\text { sel et Weyland) Knobloch et } \\
\text { Kvaček }\end{array}$ & \multicolumn{2}{|l|}{ problematic record } & leaf & 1 \\
\hline 43 & Myricaceae & Myrica lignitum & $\begin{array}{l}\text { Myrica sp. type } \\
M . \text { cf. lignitum }\end{array}$ & $\begin{array}{l}\text { Velitzelos D. et al., } \\
2014 \text { and in this } \\
\text { study }\end{array}$ & leaves & 8 \\
\hline 44 & \multirow{4}{*}{ Juglandaceae } & Engelhardia orsbergensis & $\begin{array}{l}\text { cf. Engelhardia } \\
\text { orsbergensis }\end{array}$ & $\begin{array}{l}\text { Mantzouka et al., } \\
2015 \text { and in this } \\
\text { study }\end{array}$ & leaflets & 6 \\
\hline 45 & & $\begin{array}{l}\text { Engelhardia macroptera } \\
\text { (Brongniart) Unger }\end{array}$ & $\begin{array}{l}\text { cf. Palaeocarya } \\
\text { macroptera }\end{array}$ & $\begin{array}{l}\text { Velitzelos D. et al., } \\
2014 \text { and in this } \\
\text { study }\end{array}$ & samara & 1 \\
\hline 46 & & $\begin{array}{l}\text { Carya serrifolia (Goeppert) } \\
\text { Kräusel }\end{array}$ & \multirow{2}{*}{\multicolumn{2}{|c|}{ Velitzelos D. et al., 2014}} & leaf & 1 \\
\hline 47 & & Juglans vel Carya sp. & & & fruit & 1 \\
\hline 48 & \multirow{3}{*}{ Betulaceae } & $\begin{array}{l}\text { cf. Alnus gaudinii } \\
\text { (Heer) Knobloch et Kvažek }\end{array}$ & & & leaf & 1 \\
\hline 49 & & Carpinus sp. & & & leaves & 8 \\
\hline 50 & & Carpinus type orientalis & & & fruits & 2 \\
\hline 51 & \multirow{3}{*}{ Salicaceae } & ?Salix type purpurea & & & leaf & 1 \\
\hline 52 & & Salix type 1 & & & leaves & 7 \\
\hline 53 & & Populus sp. & & & fruit & 1 \\
\hline 54 & cf. Myrtaceae & gen. et sp. indet. & \multicolumn{2}{|l|}{ problematic record } & leaves & 3 \\
\hline 55 & Anacardiaceae & ?type Pistacia lentiscus & \multicolumn{2}{|l|}{ problematic record } & leaflets & 2 \\
\hline 56 & \multirow{5}{*}{ Sapindaceae } & ?Acer sp. (5-lobed) & \multicolumn{2}{|c|}{$\begin{array}{l}\text { Velitzelos et al. (2014) listed as Acer } \\
\text { integerrimum }\end{array}$} & leaves & 2 \\
\hline 57 & & $\begin{array}{l}\text { Acer integrilobum and/or } \\
\text { A. pseudomonspessulanum } \\
\text { Unger }\end{array}$ & $\begin{array}{l}\text { Acer ser. } \\
\text { Monspessulana }\end{array}$ & in this study & leaves & 14 \\
\hline 58 & & Acer angustilobum Heer & \begin{tabular}{|l|} 
cf. Ampelopsis vel \\
Vitis sp.
\end{tabular} & $\begin{array}{l}\text { Mantzouka et al., } \\
2015\end{array}$ & leaf & 1 \\
\hline 59 & & $\begin{array}{l}\text { Acer ? integerrimum (Viviani) } \\
\text { Massalongo }\end{array}$ & \multicolumn{2}{|l|}{ Zidianakis, 2018} & leaf & 1 \\
\hline 60 & & Acer spp. (3 different types) & & & samaras & 3 \\
\hline 61 & Rutaceae & cf. Toddalia sp. & & & seed & 1 \\
\hline 62 & Thymelaeaceae & Aquilaria sp. & & & leaf & 1 \\
\hline 63 & Tiliaceae & cf. Tilia sp. & & & bracts & 2 \\
\hline 64 & Symplocaceae & $\begin{array}{l}\text { ?Symplocos cf. minutula } \\
\text { (Sternberg) Kirchheimer }\end{array}$ & & & seed & 1 \\
\hline 65 & Oleaceae & Fraxinus sp. & & & fruit & 1 \\
\hline 66 & Aquifoliaceae & ?Ilex type aquifolium & \multicolumn{2}{|l|}{ problematic record } & leaf & 1 \\
\hline 67 & Caprifoliaceae & ?Lonicera type etrusca & \multicolumn{2}{|l|}{ problematic record } & leaf & 1 \\
\hline 68 & --- & Monocotylophyllum spp. & & leaf fragments & leaves & $\begin{array}{c}\text { numer- } \\
\text { ous }\end{array}$ \\
\hline 69 & --- & $\begin{array}{l}\text { Asterocalyx styriacus } \\
\text { Ettingshausen }\end{array}$ & as Blütenreste & $\begin{array}{l}\text { Kovar-Eder et al., } \\
2004\end{array}$ & flower & 1 \\
\hline 70 & --- & $\begin{array}{l}\text { Dicotylophyllum spp. ( } 20 \text { dif- } \\
\text { ferent types, we exclude } D \text {. } \\
\text { type } 3 \text { as cf. Ziziphus para- } \\
\text { disiaca and } D \text {. type } 9 \text { as Ber- } \\
\text { beridaceae) }\end{array}$ & & & leaves/leaflets & 38 \\
\hline 71 & --- & $\begin{array}{l}\text { Carpolithus spp. (3 different } \\
\text { types) }\end{array}$ & & & fruits/seeds & 4 \\
\hline
\end{tabular}


Appendix 8. Vrysses palaeoflora (Zidianakis et al., 2007), amended floristic list taking into account the newly described findings in Zidianakis et al. (2016) and unpublished data

\begin{tabular}{|c|c|c|c|c|c|c|}
\hline \multirow[b]{2}{*}{ Nr. } & \multirow[b]{2}{*}{ Family } & \multirow[b]{2}{*}{$\begin{array}{l}\text { Taxon } \\
\text { (Zidianakis et al., 2007) }\end{array}$} & \multicolumn{2}{|c|}{$\begin{array}{l}\text { Remarks for revised or further } \\
\text { taxa }\end{array}$} & \multirow[b]{2}{*}{$\begin{array}{l}\text { Plant part/ } \\
\text { organ }\end{array}$} & \multirow[b]{2}{*}{ Samples } \\
\hline & & & \begin{tabular}{|c} 
Original identifica- \\
tion in Zidianakis et \\
al. (2007)
\end{tabular} & $\begin{array}{l}\text { Reference } \\
\text { for revision }\end{array}$ & & \\
\hline \multicolumn{7}{|c|}{ Gymnospermae } \\
\hline 1 & Cupressaceae & $\begin{array}{l}\text { Tetraclinis brachyodon (Brongniart) Mai } \\
\text { et Walther }\end{array}$ & Tetraclinis sp. & in this study & leafy twigs & 4 \\
\hline 2 & \multirow[t]{2}{*}{ Pinaceae } & Pinus sp. 2-needled & & & $\begin{array}{l}\text { dwarf shoots/ } \\
\text { needle frag- } \\
\text { ments }\end{array}$ & 17 \\
\hline 3 & & Pinus pitsidiensis & Zidianakis et al., 2016 & & dwarf shoot & 1 \\
\hline \multicolumn{7}{|c|}{ Angiospermae } \\
\hline 4 & Lauraceae & Daphnogene polymorpha & & & leaves & 2 \\
\hline 5 & Buxaceae & Buxus pliocenica Saporta et Marion & & & leaf & 1 \\
\hline 6 & Fabaceae & gen. et sp. indet. ( 2 different types) & & & leaflets & 2 \\
\hline 7 & Rosaceae & gen. et sp. indet. & & & leaves/leaflets & 3 \\
\hline 8 & Ulmaceae & gen. et sp. indet. & problematic record & & leaf & 1 \\
\hline 9 & Hamamelidaceae & $\begin{array}{l}\text { ?"Parrotia" pristina } \\
\text { (Ettingshausen) Stur }\end{array}$ & & & leaf & 1 \\
\hline 10 & Rhamnaceae & Ziziphus paradisiaca & $\begin{array}{l}\text { ?Ziziphus ziziphoides } \\
\text { (Unger) Weyland }\end{array}$ & in this study & leaves & 8 \\
\hline 11 & \multirow{2}{*}{ Fagaceae } & Quercus mediterranea & & & leaves & 12 \\
\hline 12 & & Quercus sp. & & & leaves & 3 \\
\hline 13 & Myricaceae & Myrica lignitum & unpublished data & & leaves & \\
\hline 14 & Juglandaceae & ?Juglans acuminata A. Braun ex Unger & & & leaflets & 3 \\
\hline 15 & \multirow{2}{*}{ Salicaceae } & ?Salix sp. & & & leaf & 1 \\
\hline 16 & & Populus latior & Populus tremula foss. & in this study & leaves & 2 \\
\hline 17 & \multirow{2}{*}{ Sapindaceae } & $\begin{array}{l}\text { Acer integrilobum and/or } \\
\text { A. pseudomonspessulanum Unger }\end{array}$ & $\begin{array}{l}\text { A. pseudomonspessu- } \\
\text { lanum Unger }\end{array}$ & in this study & leaves & 16 \\
\hline 18 & & $\begin{array}{l}\text { Acer cf. integerrimum } \\
\text { (Viviani) Massalongo }\end{array}$ & Acer sp. & $\begin{array}{l}\text { Velitzelos et } \\
\text { al., } 2014\end{array}$ & leaves & 5 \\
\hline 19 & --- & $\begin{array}{l}\text { Monocotylophyllum spp. } \\
\text { (2 different types) }\end{array}$ & & & leaf fragments & 18 \\
\hline 20 & --- & Dicotylophyllum spp. (12 different types) & & & leaves & 23 \\
\hline
\end{tabular}


Appendix 9. Coexistence Approach, scoring sheets for a. Pitsidia and b. Metochia

\begin{tabular}{|c|c|c|c|c|c|c|c|c|c|c|c|c|c|c|c|}
\hline \multicolumn{16}{|c|}{ a. Pitsidia (Messara) } \\
\hline Fossil taxon & Reference taxa & $\begin{array}{l}\text { 寻 } \\
\text { 它 } \\
\end{array}$ & 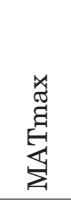 & $\underbrace{\stackrel{\Xi}{G}}_{\text {罗 }}$ & 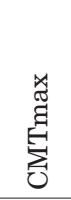 & 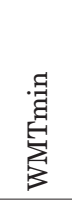 & 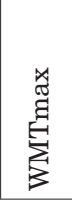 & $\begin{array}{l}\text { 寻 } \\
\text { 蓠 }\end{array}$ & 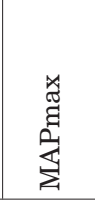 & 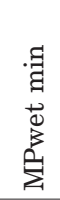 & 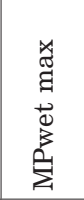 & 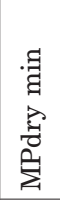 & 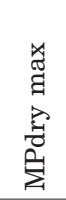 & 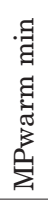 & 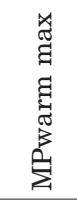 \\
\hline Polypodiophyta & Polypodiophyta & unspecific & & & & & & & & & & & & & \\
\hline $\begin{array}{l}\text { "Pteris" } \\
\text { oeningensis }\end{array}$ & Polypodiophyta & unspecific & & & & & & & & & & & & & \\
\hline $\begin{array}{l}\text { Tetraclinis } \mathrm{cf} \\
\text { salicornioides }\end{array}$ & $\begin{array}{l}\text { Tetraclinis } \\
\text { articulata }\end{array}$ & relict & & & & & & & & & & & & & \\
\hline Taxodium dubium & Taxodium sp. & 13.3 & 25 & -0.1 & 19.8 & 18.9 & 31.2 & 290 & 2615 & 60 & 265 & 0 & 93 & 19 & 227 \\
\hline Pinus pitsidiensis & Pinus sp. & -9.2 & 25.5 & -36.8 & 21.4 & 7.1 & 32.9 & 180 & 10798 & 28 & 2446 & 0 & 94 & 0 & 1100 \\
\hline Pinus 2-needled & Pinus sp. & -9.2 & 25.5 & -36.8 & 21.4 & 7.1 & 32.9 & 180 & 10798 & 28 & 2446 & 0 & 94 & 0 & 1100 \\
\hline Pinus 5-needled & Pinus sp. & -9.2 & 25.5 & -36.8 & 21.4 & 7.1 & 32.9 & 180 & 10798 & 28 & 2446 & 0 & 94 & 0 & 1100 \\
\hline $\begin{array}{l}\text { Daphnogene } \\
\text { polymorpha }\end{array}$ & $\begin{array}{l}\text { Cinnamomum } \\
\text { camphora }\end{array}$ & 13.5 & 27.2 & 2.5 & 26.1 & 18.6 & 31.7 & 828 & 10798 & 160 & 2446 & 3 & 135 & 30 & 1100 \\
\hline ? Lindera ovata & Lauraceae & 4.4 & 28.1 & -16.8 & 27 & 19.3 & 30.1 & 191 & 10798 & 56 & 2446 & 0 & 165 & 0 & 1100 \\
\hline ?Lauraceae & Lauraceae & 4.4 & 28.1 & -16.8 & 27 & 19.3 & 30.1 & 191 & 10798 & 56 & 2446 & 0 & 165 & 0 & 1100 \\
\hline $\begin{array}{l}\text { Liquidambar } \\
\text { europaea }\end{array}$ & $\begin{array}{l}\text { Liquidambar } \\
\text { styraciflua, } \\
\text { L. orientalis }\end{array}$ & 12.5 & 21.3 & -0.1 & 16.3 & 19.6 & 28.6 & 897 & 1613 & 106 & 265 & 2 & 93 & 84 & 195 \\
\hline $\begin{array}{l}\text { Leguminosites } \\
\text { sp. } 1\end{array}$ & Fabaceae & -7.7 & 27.7 & -22.7 & 25.9 & 10.5 & 28.1 & 224 & 3905 & 46 & 610 & 0 & 196 & 1 & 221 \\
\hline $\begin{array}{l}\text { Leguminosites } \\
\text { sp. } 2\end{array}$ & Fabaceae & -7.7 & 27.7 & -22.7 & 25.9 & 10.5 & 28.1 & 224 & 3905 & 46 & 610 & 0 & 196 & 1 & 221 \\
\hline $\begin{array}{l}\text { Podocarpium } \\
\text { podocarpum }\end{array}$ & Fabaceae & -7.7 & 27.7 & -22.7 & 25.9 & 10.5 & 28.1 & 224 & 3905 & 46 & 610 & 0 & 196 & 1 & 221 \\
\hline Mimosites sp. & Fabaceae & -7.7 & 27.7 & -22.7 & 25.9 & 10.5 & 28.1 & 224 & 3905 & 46 & 610 & 0 & 196 & 1 & 221 \\
\hline Rosaceae & Rosaceae & -15 & 27.7 & -41 & 26.5 & 3.6 & 32.9 & 122 & 10798 & 22 & 2446 & 0 & 229 & 0 & 1100 \\
\hline $\begin{array}{l}\text { Ulmus } \text { cf. } \\
\text { purinervia }\end{array}$ & Ulmus sp. & -4.9 & 26.6 & -25.8 & 26.1 & 16 & 29.4 & 201 & 3285 & 33 & 569 & 0 & 100 & 0 & 239 \\
\hline $\begin{array}{l}\text { ?Zelkova } \\
\text { zelkovaefolia }\end{array}$ & ova sp. & 6.2 & 21.9 & 12.8 & 13.6 & 19.4 & 29.7 & 246 & 2648 & 46 & 370 & 3 & 67 & 3 & 344 \\
\hline $\begin{array}{l}\text { Quercus } \\
\text { pseudocastanea }\end{array}$ & Quercus sp. & -1.4 & 27 & -25.1 & 25.9 & 8.4 & 28.3 & 201 & 10798 & 33 & 2446 & 0 & 180 & 5 & 1100 \\
\hline Quercus kubinyii & $\begin{array}{l}\text { Quercus sect. } \\
\text { Cerris }\end{array}$ & 4.7 & 22.2 & -8.7 & 15.6 & 11.7 & 28.6 & 470 & 3000 & 48 & 2695 & 0 & 85 & 0 & 1781 \\
\hline $\begin{array}{l}\text { Quercus } \\
\text { mediterranea }\end{array}$ & $\begin{array}{l}\text { Quercus sect. } \\
\text { Cerris }\end{array}$ & 4.7 & 22.2 & -8.7 & 15.6 & 11.7 & 28.6 & 470 & 3000 & 48 & 2695 & 0 & 85 & 0 & 1781 \\
\hline Fagus gussonii & $\begin{array}{l}\text { Fagus sp. } \\
\text { (Europe) }\end{array}$ & 5.9 & 19.7 & -5 & 9.4 & 17.1 & 31.7 & 376 & 2115 & 46 & 195 & 5 & 94 & 5 & 195 \\
\hline Myrica lignitum & Myrica sp. & -8.9 & 28.1 & -29 & 27 & 8.9 & 33.9 & 233 & 151 & 34 & 508 & 0 & 165 & 0 & 221 \\
\hline Carya sp. & Carya sp. & 4.4 & 21.3 & -11.5 & 18.2 & 19.3 & 30.6 & 373 & 1724 & 68 & 434 & 8 & 93 & 45 & 258 \\
\hline Pterocarya sp. & Pterocarya sp. & 3.9 & 24.2 & -12.8 & 17 & 15.3 & 31.6 & 246 & 2648 & 46 & 424 & 1 & 64 & 2 & 424 \\
\hline Juglandaceae & Juglandaceae & 0 & 27.5 & -22.7 & 25 & 13.7 & 31.2 & 210 & 3172 & 44 & 582 & 1 & 152 & 2 & 189 \\
\hline cf. Ostrya sp. & Ostrya & 2.5 & 21.9 & -17.7 & 19.3 & 18.9 & 28.1 & 279 & 1355 & 74 & 237 & 0 & 72 & 0 & 228 \\
\hline Salix sp. & Salix sp. & -17 & 27.7 & -50.1 & 26.5 & 7.6 & 32.9 & 122 & 2399 & 22 & 448 & 0 & 108 & 0 & 252 \\
\hline Populus latior & Populus alba & 2.5 & 18.5 & -14.6 & 12.5 & 17.9 & 26.4 & 419 & 1741 & 57 & 254 & 1 & 109 & 3 & 80 \\
\hline Populus sp. & Populus sp. & -16 & 26 & -49 & 13.6 & 9.8 & 35.6 & 25 & 2559 & 8 & 358 & 0 & 93 & 0 & 224 \\
\hline $\begin{array}{l}\text { Acer } \\
\text { tricuspidatum }\end{array}$ & $\begin{array}{l}\text { Acer sectio } \\
\text { Rubra }\end{array}$ & 3.4 & 23.9 & -12.9 & 19.4 & 18.8 & 29.4 & 735 & 1613 & 102 & 241 & 20 & 94 & 49 & 177 \\
\hline Acer integrilobum & $\begin{array}{l}\text { Acer sect. } \\
\text { Palmata }\end{array}$ & 6.2 & 24 & -8.1 & 20.6 & 16.7 & 29.3 & 529 & 10798 & 116 & 2446 & 0 & 135 & 26 & 1100 \\
\hline $\begin{array}{l}\text { ?Acer } \\
\text { aegopodifolium }\end{array}$ & $\begin{array}{l}\text { Acer sectio } \\
\text { Trifolia }\end{array}$ & 3.3 & 18.5 & -20.1 & 7.7 & 23.3 & 29.3 & 577 & 1724 & 167 & 358 & 4 & 64 & 78 & 258 \\
\hline $\begin{array}{l}\text { Monocotylophyl- } \\
\text { lum sp. 1-5 }\end{array}$ & $\begin{array}{l}\text { Monocotyledo- } \\
\text { nae }\end{array}$ & unspecific & & & & & & & & & & & & & \\
\hline $\begin{array}{l}\text { Taxa with climatic } \\
\text { data }\end{array}$ & 30 & & & & & & & & & & & & & & \\
\hline $\begin{array}{l}\text { Coexistence } \\
\text { intervals }\end{array}$ & & 13,5 & 18.5 & 2.5 & 7.7 & 23.3 & 28.1 & 897 & 1613 & 167 & 195 & 20 & 64 & 78 & 80 \\
\hline $\begin{array}{l}\text { Coexisting taxa } \\
(\%)\end{array}$ & & & 100 & & 100 & & 100 & & 100 & & 100 & & 100 & & 96.7 \\
\hline
\end{tabular}


Appendix 9. Continued

\begin{tabular}{|c|c|c|c|c|c|c|c|c|c|c|c|c|c|c|c|}
\hline \multicolumn{16}{|l|}{. Metochia (Gavdos) } \\
\hline Fossi & Refer & 当 & 离 & $\begin{array}{l}\stackrel{\Xi}{\Xi} \\
\sum_{0}^{E}\end{array}$ & 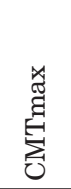 & 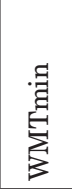 & $\sum_{j}^{\infty}$ & 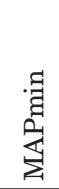 & 离 & 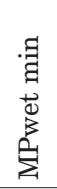 & 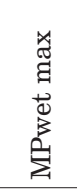 & 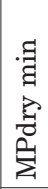 & 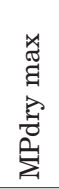 & 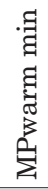 & 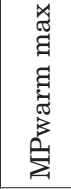 \\
\hline $\begin{array}{l}\text { Tetraclinis cf. } \\
\text { salicornioides }\end{array}$ & $\begin{array}{l}\text { Tetraclinis } \\
\text { articulata }\end{array}$ & relict & & & & & & & & & & & & & \\
\hline Taxodium dubium & Taxodium $\mathrm{s}$ & 13.3 & 25 & -0.1 & 19.8 & 18.9 & 31.2 & 290 & 2615 & 60 & 265 & 0 & 93 & 19 & 227 \\
\hline Pinus 2-needled & Pinus sp. & -9.2 & 25.5 & -36.8 & 21.4 & 7.1 & 32.9 & 180 & 10798 & 28 & 2446 & 0 & 94 & 0 & 1100 \\
\hline Pinus 5-needled & Pinus sp. & -9.2 & 25.5 & -36.8 & 21.4 & 7.1 & 32.9 & 180 & 10798 & 28 & 2446 & 0 & 94 & 0 & 1100 \\
\hline Daphnogene sp. & Laur & 4.4 & 28.1 & -16.8 & 27 & 19.3 & 30.1 & 191 & 10798 & 56 & 2446 & 0 & 165 & 0 & 1100 \\
\hline Laurophyllum sp. & Lau & 4.4 & 28.1 & -16.8 & 27 & 19.3 & 30.1 & 191 & 10798 & 56 & 2446 & 0 & 165 & 0 & 1100 \\
\hline ?Lindera ovata & Laur & 4.4 & 28.1 & -16.8 & 27 & 19.3 & 30.1 & 191 & 10798 & 56 & 2446 & 0 & 165 & 0 & 1100 \\
\hline ?Sassafras $\mathrm{sp}$. & Sassafras $\mathrm{s}$ & 6.5 & 22.8 & -7.9 & 14.7 & 19.6 & 30.1 & 843 & 1864 & 71 & 295 & 17 & 93 & 64 & 195 \\
\hline Sabalites sp. & Arec & 13.3 & 27.7 & -0.1 & 27 & 22.8 & 33.1 & 37 & 3151 & 8 & 389 & 0 & 165 & 0 & 225 \\
\hline $\begin{array}{l}\text { Leguminosites spp. } \\
\text { (5 types) }\end{array}$ & $\mathrm{F}$ & -7.7 & 27.7 & .7 & 25.9 & 10.5 & 28.1 & 224 & 905 & 46 & 610 & 0 & 196 & 1 & 221 \\
\hline Paliurus tiliifolius & iurus sp. & 10 & 23.1 & -7.3 & 17 & 22.5 & 28.8 & 396 & 1958 & 68 & 448 & 2 & 70 & 2 & 431 \\
\hline $\begin{array}{l}\text { Ziziphus } \\
\text { paradisiaca }\end{array}$ & Rham & 6 & 27.7 & 1 & 27 & 16.3 & 33.1 & 37 & 3151 & 8 & 89 & 0 & 165 & 0 & 221 \\
\hline Ulmus cf. purinervia & Ulmus & -4.9 & 26.6 & -25.8 & 26.1 & 16 & 29.4 & 201 & 3285 & 33 & 569 & 0 & 100 & 0 & 239 \\
\hline $\begin{array}{l}\text { Quercus } \\
\text { mediterranea }\end{array}$ & $\begin{array}{l}\text { Querc } \\
\text { Cerri }\end{array}$ & 4.7 & 22.2 & 3.7 & 15.6 & 11.7 & 28.6 & 470 & 3000 & 48 & 2695 & 0 & 85 & 0 & 1781 \\
\hline Fagus gussonii & Fagus sp. (Eu & 5.9 & 19.7 & -5 & 9.4 & 17.1 & 31.7 & 376 & 2115 & 46 & 195 & 5 & 94 & 5 & 195 \\
\hline Myrica lignitum & Myrica sp. & -8.9 & 28.1 & -29 & 27 & 8.9 & 33.9 & 233 & 3151 & 34 & 508 & 0 & 165 & 0 & 221 \\
\hline $\begin{array}{l}\text { Engelhardia } \\
\text { orsbergensis }\end{array}$ & Engelhardic & 13.8 & 27.4 & 3.1 & 26.1 & 18.9 & 33.6 & 748 & 10798 & 170 & 2446 & 0 & 152 & 48 & 1100 \\
\hline Betula sp. & Betula sp. & -15 & 25.8 & -41 & 21.1 & 1.3 & 28.7 & 110 & 10798 & 23 & 2446 & 0 & 135 & 2 & 100 \\
\hline ?Carpinus sp. & Carpinus sp. & 0 & 25.8 & -22.7 & 21.1 & 16.8 & 28.7 & 164 & 10798 & 20 & 2446 & 0 & 130 & 2 & 1100 \\
\hline Salix cf. angusta & Salix sp. & -17 & 27.7 & -50.1 & 26.5 & 7.6 & 32.9 & 122 & 2399 & 22 & 448 & 0 & 108 & 0 & 252 \\
\hline Populus latior & Populus alba & 2.5 & 18.5 & -14.6 & 12.5 & 17.9 & 26.4 & 419 & 1741 & 57 & 254 & 1 & 109 & 3 & 80 \\
\hline Sapindus graecus & Sapindus sp. & 10 & 27.7 & -7.3 & 27 & 20.2 & 32.9 & 184 & 3151 & 22 & 389 & 2 & 165 & 20 & 304 \\
\hline Acer angustilobum & Acer sect. Acer & 2.7 & 24 & -15.6 & 20.6 & 16.2 & 28.6 & 115 & 2559 & 19 & 370 & 1 & 135 & 1 & 366 \\
\hline Ailanthus pythii & Ailanthus sp. & 6.9 & 26.7 & -8.1 & 25.3 & 18.3 & 28.9 & 376 & 3459 & 92 & 638 & 1 & 119 & 73 & 304 \\
\hline Monocotyledonae & Monocotyledonae & unspecific & & & & & & & & & & & & & \\
\hline $\begin{array}{l}\text { Taxa with climatic } \\
\text { data }\end{array}$ & 23 & & & & & & & & & & & & & & \\
\hline Coexistence intervals & & 13,8 & 18.5 & 3.1 & 9.4 & 22.8 & 26.4 & 843 & 1741 & 170 & 195 & 17 & 70 & 73 & 80 \\
\hline Coexisting taxa (\%) & & & 100 & & 100 & & 100 & & 100 & & 100 & & 100 & & 95.7 \\
\hline
\end{tabular}


Appendix 10. Percentages of foliar physiognomic characters derived by CLAMP for Pitsidia and Metochia

\begin{tabular}{|c|c|c|c|}
\hline \multicolumn{2}{|l|}{ Foliar physiognomic character } & $\begin{array}{c}\text { Pitsidia } \\
\text { (in this study) } \\
\end{array}$ & $\begin{array}{c}\text { Metochia } \\
\text { (Mantzouka et al., 2015) } \\
\end{array}$ \\
\hline \multirow{7}{*}{ Margin character states } & Lobed & 6,757 & 7.69 \\
\hline & No teeth & 45,946 & 59.62 \\
\hline & Teeth regular & 35,811 & 21.15 \\
\hline & Teeth close & 29,730 & 18.27 \\
\hline & Teeth round & 24,324 & 20.15 \\
\hline & Teeth acute & 28,378 & 23.08 \\
\hline & Teeth compound & 0,000 & 7.69 \\
\hline \multirow{9}{*}{ Size character states } & Nanophyll & 0,000 & 0.00 \\
\hline & Leptophyll I & 2,703 & 0.00 \\
\hline & Leptophyll II & 14,405 & 0.00 \\
\hline & Microphyll I & 25,189 & 0.00 \\
\hline & Microphyll II & 38,676 & 41.62 \\
\hline & Microphyll III & 12,108 & 29.42 \\
\hline & Mesophyll I & 6,730 & 27.50 \\
\hline & Mesophyll II & 0,000 & 1.27 \\
\hline & Mesophyll III & 0,000 & 0.00 \\
\hline \multirow{4}{*}{ Apex character states } & Apex emarginated & 9,375 & 0.00 \\
\hline & Apex round & 18,219 & 34.23 \\
\hline & Apex acute & 61,969 & 55.96 \\
\hline & Apex attenuate & 16,656 & 9.81 \\
\hline \multirow{3}{*}{ Base character states } & Base cordate & 10,000 & 1.92 \\
\hline & Base round & 51,429 & 40.38 \\
\hline & Base acute & 38,571 & 57.96 \\
\hline \multirow{5}{*}{ Length to width character states } & $\mathrm{L}: \mathrm{W}<1: 1$ & 10,351 & 0.00 \\
\hline & $\mathrm{L}: \mathrm{W}=1-2: 1$ & 29,243 & 18.58 \\
\hline & $\mathrm{L}: \mathrm{W}=2-3: 1$ & 36,892 & 26.27 \\
\hline & $\mathrm{L}: \mathrm{W}=3-4: 1$ & 17,081 & 44.54 \\
\hline & $\mathrm{L}: \mathrm{W}>4: 1$ & 6,297 & 10.58 \\
\hline \multirow{3}{*}{ Shape character states } & Obovate & 18,865 & 4.62 \\
\hline & Elliptic & 49,946 & 39.23 \\
\hline & Ovate & 31,027 & 56.15 \\
\hline
\end{tabular}

